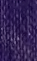




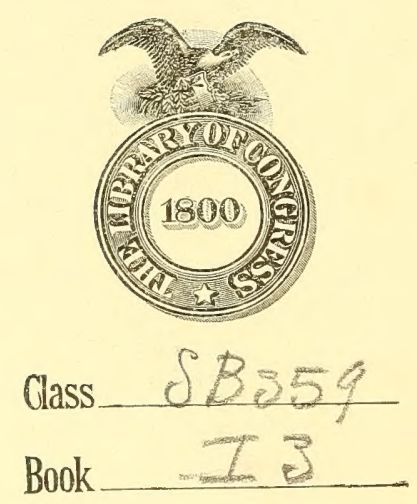









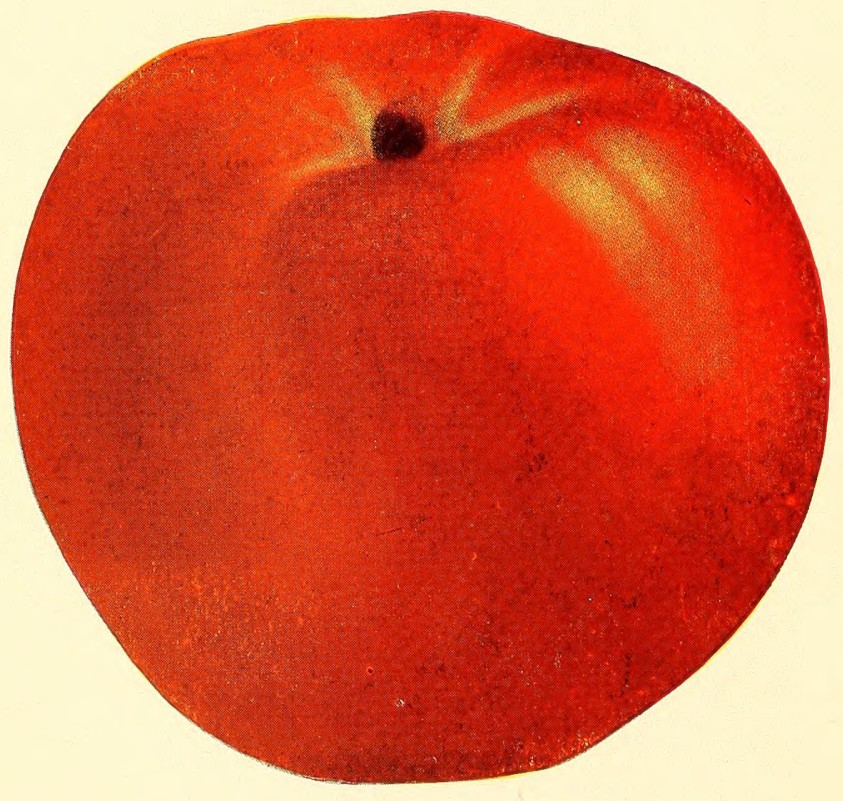

MCINTOSH RED 


\title{
A Manual of Horticulture FOR THE STATE OF IDAHO
}

\author{
बृत्री
}

\author{
COMPILED BY \\ JOHN U. McPHERSON \\ STATE INSPECTOR
}

प्राक

1913

PUBLISHED BY THF

IDAHO STATE BOARD OF

HORTICULTURE

BOISE

$$
\text { -:- IDAHO }
$$




$$
\frac{53359}{13}
$$

DESIGNED AND PRINTED THROUGHOUT IN IDAHO BY

\title{
16. The Carton Printers
} 7498

\author{
D. OF D. \\ DEC 221912
}

Colored Plates Printed by The Caxton Printzir.s. 
Report of State Inspector …................................................... 7

Financial Report of Secretary .................................................. 11

Report of State Bee Inspector …............................................ 15

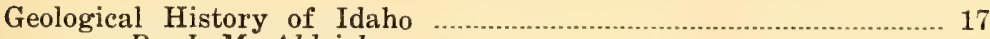
By J. M. Aldrich.

Physical Features of Idaho .............................................. 21 By Elias Nelson.

Climate of Idaho

By Edw. L. Wells.

Native Vegetation of Idaho By J. M. Aldrich.

Idaho Irrigation Methods By Don H. Bark.

Principles and Methods of Irrigation By Elias Nelson.

Fruit for Home Use By T. A. Allen.

Fruit By-products By C. J. Sinsel.

By-Products

By Fremont Wood.

Commercial Fruit Growing in Idaho By John U. McPherson.

Prune Industry in Idaho By C. J. Sinsel.

European Grapes in the Clearwater Valley By Robert Schleicher.

Science of Grading and Packing Apples By Roy C. Brock.

Principal Insects Injurious to Fruits in Idaho Compiled by John U. McPherson.

Principal Fungus Diseases of Fruits in Idaho Compiled by John U. McPherson.

Control of Pear Blight By P.J. O'Gara.

Preparation of Spraying Materials Compiled by John U. McPherson.

Reports of District Inspectors

By the Deputy Inspectors.

Appendix-Description of Colored Plates 
Plate I.- McIntosh Red Apple (Full Colors) ................. Frontisipece

Plate II. - Bartlett Pear (Full Colors) .......................................... 16

Plate III.-Map of Idaho, showing normal annual precipitation .... 25

Plate IV.-Map of Idaho, showing normal annual isotherms....... 32

Plate V.-White Winter Pearmain Apple (Full Colors) .................. 40

Plate VI.-Winesap. Apple (Full Colors) .......................................... 48

Plate VII.-Yellow Newton Apple (Full Colors) …...................... 65

Plate VIII.-Italian Prune (Full Colors) _..................................... 72

Plate IX.-View in the Vineyard of Robert Schleicher ..................... 80

Plate X.-Delicious Apple (Full Colors) ........................................ 89

Plate XI.-Fig. 1, 56 apples; Fig. 2, 72 apple; Fig. 3, 72 apples; Fig. 4, 80 apples; Fig. 5, 96 apples; Northwest Standard Box.

Plate XII.-Fig. 1, 96 apples; Fig. 2, 112 apples, Northwest Standard Box; Fig. 3, 112 apples; Fig. 4, 120 apples; Fig. 5, 158 apples, Northwest Special Box

Plate XIII.-Fig. 1, 128 apples, Northwest Special Box; Fig. 2, 138 apples; Fig. 3, 160 apples; Fig. 4, 165 apples, Northwest Standard Box

Plate XIV.-Fig. 1, Manner of starting the three and onehalf-tier pack; Fig. 2, Side view of box after nailing

Plate XV.-Fig. 1, Nailing Press, best type; Fig. 2, Northwest Greening Apple

Plate XVI.-Manner of Packing Boxes in a Car ........................ 96

Plate XVII.-Idaho Apples, Commercial Pack ................................ 98

Plate XVIII._Comice Pear (Full Colors) ....................................101

Plate XIX.-San Jose Scale ............................................................102

Plate XX.-Fig. 1, The Codling Moth; Fig. 2, Woolly Aphis .....108

Plate XXI.-Fig. 1, Mytilaspis Pomorum; Fig. 2, Peach Twig Borer

Plate XXII.-Fig. 1, Cottony Maple Scale; Fig. 2, Flatheaded Apple Tree Borer; Fig. 3, The Grape Phylloxera

Plate XXIII.-Wealthy Apple (Full Colors)

Plate XXIV.-Grimes Golden Apple (Full Colors)

Plate XXV.-Jonathan Apple (Full Colors)

Plate XXVI.-Fig. 1, Wrong Form of Pear Tree; Fig. 2, Result of Growing a Tree with Central Leader; Fig. 3, A Bad Crown Infection on Spitzenberg' Apple; Fig. 4, Body Infection of Bartlett Pear

Plate XXVII.-Fig. 1, Bartlett Pear Tree Showing Blight Eradicated from the Body; Fig. 2, A Bad Infection of the Body and Root System; Fig. 3, Crown Gall on Branch of Spitzenberg Apple; Fig. 4, Spitzenberg Infected with Pear Blight

Plate XXVIII.-Elberta Peach (Full Colors)

Plate XXIX.-Wagner Apple (Full Colors)

Plate XXX.-Anjou Pear (Full Colors)

Plate XXXI.-Rome Beauty Apple (Full Colors)

Plate XXXII.-Gano Apple (Full Colors) 


\section{LETTER OF TRANSMITTAL}

BoISE, IDAHO, December 31, 1912.

HoNORABLE JAMES H. HAWLEY,

Governor of Idaho, Boise, Idaho.

My Dear Sir-I have the honor to present to you the biennial report of the State Horticultural Inspector, and the secretary of the State Board of Horticultural Inspection, together with the reports of the Deputy Inspectors.

Examination of these reports will show that the fruit industry has advanced rapidly in the last two years. The State Inspector reports that the fruit crop of Idaho for 1912 was of a value of three millions of dollars, and it is certain that the production will increase rapidly from year to year until our fruit crop will be one of the main resources of revenue for the people of our state, as it is already the product which advertises the state more than any other one thing.

You will notice that the fruit acreage has now reached a total of 142,773 acres, with a probable increase in the coming two years.

The Board concurs in the recommendations of the State Inspector regarding the changes in the horticultural law. We feel that we should be able to allot sufficient sums of money to each district so that the necessary inspection work can be carried on the year round. We also trust that the legislature will recognize the growing importance of the work, and will make this department an appropriation of $\$ 50,000$ which is necessary to carry on the work.

All of which is respectfully submitted.

Chas. P. HaRtley,

President Idaho State Board of Horticultural Inspection. 
STATE BOARD OF HORTICULTURAL INSPECTION

Henry W. Dorman, President Caldwell JoHN U. MCPHERSON, Secretary ………………....... Boise B. F. HURST … ROBERT SCHLEICHER ….......................................... Lewiston JoHN D. C. KRUGER ……................................ St. Anthony D. L. INGARD Fruitland STATE HORTICULTURAL INSPECTOR JOHN U. MCPHERSON Boise 


\section{REPORT OF THE STATE HORTICULTURAL}

\section{INSPECTOR.}

\section{To the State Board of Horticultural Inspection:}

I submit for your approval my report as State Horticultural Inspector for the years 1911 and 1912.

I feel that the work, as a whole, has been of a benefit to not only the fruit growers of this state but to the people of the state at large. It has been my honest endeavor to strictly enforce the horticultural laws up to that point where it was of the greatest benefit to the fruit industry of the state, and also to see that every dollar that was appropriated by the state for this work has been expended for the direct benefit of the horticultural industry of the state, and I believe that the class of fruit which was raised and shipped from the state this year is evidence that this work has been of a benefit. I do not believe that there has been a year in the history of the state that the fruit has been so free from insect pests and disease, and I wish at this time to thank and commend the good work of the growers of the state for their co-operation in spraying and in the general care given their orchards. The department has carried on a very rigid inspection of all nursery stock within the state, as well as upon all stock which has been shipped into the state. During 1911 a great many thousand trees were condemned and burned which had been shipped in from adjoining states. The stock of the year 1912 showed a marked turn toward the better, and I am satisfied that our work of 1911 caused the outside nurserymen to ship in better stock than heretofore. This phase of the inspection, however, has been a very disagreeable one for the reason that our funds were very low for this work. While the law provides that the inspection of all incoming stock shall be paid for by the receiver of such stock, still at the same time it often 
occurred that the deputy inspector had to travel some distance to inspect this stock and oftentimes the inspection charges would amount to more than the stock was worth, and in that event the state had to stand some of the expense, this amount coming out of the general fund, and in that way it decreased our working capital considerably. It is my opinion that this inspection of nursery stock should be paid for by the state as it is of benefit to all the state and not only to the receiver of the stock. The inspection of incoming nursery stock should be carried on more rigidly in the coming years than it has in the past. Each year the fruit growers of the state are put to an enormous expense in spraying for the various pests which we now have, all of which were introduced into the state on incoming nursery stock, and it is necessary that all other pests which are liable to be introduced be kept out through this inspection.

I also wish to recommend that the horticultural law be strengthened to such a point that we will be able to quarantine other states for keeping out infested stock in a more direct manner. I am certain that the late controversy with California in regard to the alfalfa weevil shows an evidence of this need. The past two years we have kept a very close watch on all seedling stock for the gypsy and browntail moth. We have found several instances of the same in different parts of the state, and the stock was immediately destroyed, and I do not believe, at this time, that there are any of these pests to be found within the state.

It will be shown by the following financial statement that this department has had funds available for its biennial term of 1911 and 1912 amounting to $\$ 32,060.95$. of this amount the state appropriated $\$ 23,600.00$, and the balance of $\$ 8,460.95$ has been taken in by the department in the way of fines, fees and licenses, as well as by appropriations from nine counties in the state towards this work, and I believe that the board, as a whole, owe the different counties a vote of thanks for their kind and considerate co-operation in the inspection work. The various county officials, upon petitions placed before them signed by fruit 
growers of their respective counties, knowing that the funds of the department were limited, and realizing the importance of the work, took it upon themselves to assist us and granted the sums asked for in the petitions. Without this assistance from the various counties the work could not have been carried on.

During the past two years we have issued 150 firm licenses, and we have somewhere near 500 nursery agents in the state.

In closing I wish to make this recommendation-in the past two years the acreage in Idaho planted to fruit has doubled, and with each coming year more and greater demands will be made upon this department to assist in the horticultural work, and funds must be available to carry it on. As has been shown by the financial report we have had approximately $\$ 32,000.00$ for this work. While I consider that we have made a showing with this amount of money, still at the same time it is not nearly enough to carry on the work as it should be. The deputy inspectors throughout the state have not been able to make a living from the salaries paid them for their work, and it is impossible to expect to keep men who are able and competent to do this work if they cannot be paid for their services, and I wish to recommend at this time that the salary of each deputy in the state be placed at the rate of $\$ 100.00$ per month, when actually employed in the discharge of duties, and allow them $\$ 2.50$ per day for actual expenses. In this way competent men can be secured and kept for this work, while under the present conditions there is nothing sure as to the length of time they are to work and the pay they are to receive. The state of Idaho is, at this time, the third in number of acres planted to orchard in the northwest, and is fourth in the number of cars shipped, and our fruit crop this last year of 1912 is valued at $\$ 3,000,000$.

Fruit growing is one of the leading industries of the state while on the other hand there is less money appropriated for the inspection work of this state than in any other state of the northwest, and a great many states, 
which have a much smaller acreage, and where the number of cars of fruit shipped does not amount to half as many as the cars shipped from Idaho, are receiving more for inspection work in one year than Idaho receives for two years.

I wish to thank the members of the horticultural board for the many kindnesses which they have shown me during my term as state inspector, and the honest co-operation and backing in strict enforcement of the law.

I hope that your honorable body will approve of the work of the past two years and the recommendations which I have offered, all of which I respectfully submit to your honorable body.

J. U. MCPHERSON, State Horticultural Inspector. 


\section{FINANCIAL REPORT OF SECRETARY.}

BoISE, IDAHO, December 1, 1912.

The Board of Horticultural Inspection, Boise, Idaho.

Gentlemen-I herewith submit my report covering disbursements of the funds of the Board from January 1, 1911, to December 1, 1912. This report includes the salary of the state inspector, traveling and office expenses, as well as the per diem of the deputy inspectors; also the expenses of the Board while attending meetings:

1911-

John U. McPherson, state inspector, salary_.....\$ 1,725.00

John U. McPherson, state inspector, expenses

$$
\text { stamps, etc., }
$$

General office expense, including stenographer .. $1,158.27$

Printing bulletins

C. P. Hartley, Pres. Board, attending meetings

J. R. Field, salary one month as state insp.

150.00

M. B. Sherman, board member, expense attending meetings

Robt. Schleicher, board member, expense attending meetings

90.50

O. F. Smith, board member, expense attending meetings

Wm. Buckley, insp. Dist. No. 1

574.00

32.00

Samuel Mayne, asst. insp. Dist. No. 1

435.00

W. C. Edmundson, insp. Dist. No. 2

565.00

G. E. Ames, insp Dist. No. 3

7.50

D. A. Smith, asst. insp. Dist. No. 3

501.00

H. T. Murray, insp. Dist. No. 4

20.00

H. M. Williams, asst. insp Dist. No. 4

11.00

T. W. Hanan, asst. insp. Dist. No. 4

8.00

J. S. Hogue, asst insp. Dist. No. 4

10.00

A. J. Stuart, asst. insp. Dist. No. 4

100.54 
D. B. Webber, inspector District No. 5

622.00

A. R. Ingalls, inspector District No. 6

137.50

L. E. Newcomb, inspector District No. 6

1.007 .43

Thos. Hance, assistant inspector District No. 6

164.00

A. B. Kern, assistant inspector District No. 6...

64.00

J. Bradfield, assistant inspector District No. 6 .. Robt. Hyslop, inspector District No. 7

60.00

Edgar Meek, assistant inspector District No. 7

80.00

Edgar Meek, inspector District No. 7

20.00

Harry Meek, assistant inspector District No. 7

736.00

G. J. Taylor, inspector District No. 8

100.00

B. E. Rayburn, assistant inspector District No. 8

405.00

B. E. Rayburn, inspector District No. 8

132.00

H. P. Ashby, assistant inspector District No. $8 \ldots$

C. W. Brannan, inspector District No. 9

880.00

379.00

B. F. Flesher, assistant inspector District No. 9

$1,098.35$

C. B. Dull, assistant inspector District No. 9...

33.20

24.50

Carl Walters, assistant inspector District No. 9

26.25

Tage Carlson, assistant inspector District No. 9 John Adams, inspector District No. 10

69.90

Wm. Morgan, inspector District No. 11 ............

J. G. Nelson, inspector District No. 12

120.00

200.00

W. T. Hawkey, inspector District No. 13 ..........

415.00

612.00

R. E. Harris, assistant inspector District No. 13

12.00

K. Parkinson, assistant inspector District No. 13

Homer Chaffee, inspector District No. 14

17.60

285.00

H. Ostrander, asst. inspector District No. 14

16.00

Total

$\$ 14,399.09$

\section{2}

John U. McPherson, state inspector, salary …...\$2,375.00

John U. McPherson, exp. traveling, stamps, etc... 1,217.00

General office expense, including stenographer .... $1,467.25$

Printing bulletins, etc., .......................... 93

J. R. Field, board member $\ldots$

Robert Schleicher, board nember ...................... $\quad 39.45$

John D. C. Kruger, board member …........................ 72.

Wm. Buckley, inspector District No. $1 \ldots \ldots . . . . . . . . \quad 440.00$

W. F. Scott, assistant inspector District No. 1.... 30.35 
Samuel Mayne, assistant inspector District No. 1

W. C. Edmundson, inspector District No. 2 ..........

W. M. Herman, assistant inspector District No. 2 595.00

G. E. Ames, inspector District No. 3

5.00

O. G. Ogsbury, assistant inspector District No. 3 602.50

A. N. Sager, assistant inspector District No. 3

Henry T. Murray, inspector District No. 4

John A. Powell, inspector District No. 4

476.00

T. W. Hanan, assistant inspector District No. 4 .. 102.00

J. S. Hogue, assistant inspector District No. 4 48.00

A. J. Stuart, assistant inspector District No. 4 ....

H. C. Oliver, assistant inspector District No. 4...

42.50

F. T. Moore, assistant inspector District No. 4...

D. B. Webber, inspector District No. 5

50.95

6.13

L. E. Newcomb, inspector District No. 6

A. B. Kern, inspector District No. 6

210.00

James Kinzer, assistant inspector District No. 6 J. Bradfield, assistant inspector District No. 6 .... Edgar Meek, inspector District No. 7

920.00

75.00

42.00

C. L. Park, assistant inspector District No. 7 ....

795.25

122.50

J. D. Bloomfield, asst. inspector District No. 7

H. P. Ashby, inspector District No. 8

129.55

F. L. Rickey, assistant inspector District No. 8

$1,057.40$

44.20

B. E. Rayburn, assistant inspector District No. 8

25.00

W. M. Funstan, assistant inspector District No. 8

68.00

George Fenton, assistant inspector District No. 8 C. W. Brannan, inspector District No. 9

151.45

748.60

A. J. Milner, assistant inspector District No. 9

75.50

C. B. Dull, assistant inspector District No. $9 \ldots \ldots$

114.30

Robt. Simpson, asst. inspector Distdict No. 9 ....

14.00

A. P. Senior, assistant inspector District No. 9

91.00

B. F. Flesher, assistant inspector District No. 9

18.50

A. J. Mye, assistant inspector District No. 9.

17.80

B. F. Hays, assistant inspector District No. 9.....

John Adams, inspector District No. 10

9.00

110.00

T. J. Evans, inspector District No. 11

451.00

R. H. Christensen, asst. inspector Dist. No. 11 ....

43.95

P. A. Hanson, assistant inspector District No. 11

John Norton, inspector District No. 12

28.00

424.00

W. T. Hawkey, inspector District No. 13

258.00 
H. T. Brengman, inspector District No. 13

563.94

H. E. Fisher, assistant inspector District No. 13

12.00

I. C. Smith, assistant inspector District No. 13...

55.75

K. Parkinson, assistant inspector District No. 13

Homer Chaffee, inspector District No. 14

Total

$\$ 15,486.86$

Total expenditures, 1911

$\$ 14,399.09$

Total expenditures, 1912 to Dec. 1..... 15,486.86

Total from Hort. fund, biennial term.-

$29,885.95$

Funds as appropriated by state $23,600.00$

Hort. insp. fund, fees, fines, licenses.. 4,979.09

Hort. and Bee fund, 1911 and 1912 ... 1,306.86

Appropriated by counties, 1911......... 600.00

Appropriated by counties, $1912 \ldots \ldots . . . . \quad 1,575.00$

County Claims, 1911

County claims, 1912, to Dec. 1

Balance, county funds, 1912

789.15

$\$ 32,060.95 \$ 32,060.95$

Respectfully submitted,

JOHN U. MCPHERSON, Secretary State Board Hort. Insp. 


\section{REPORT OF STATE BEE INSPECTOR.}

Hon. James H. Hawley, Governor of Idaho, Boise, Idaho.

My Dear Governor-According to law the work of the State Bee Inspection is handled through the Horticultural Department, and the State Horticultural Inspector is exofficio State Bee Inspector.

There are some 25 deputy bee inspectors in the state, some of whom work for what might be termed the good of the state, as the funds for this work have been very limited and some of the inspectors, knowing this, have asked to be appointed merely as a matter of protection to their neighborhood, or in some cases, their own bees.

There is a great deal of foul brood in some localities in the state, and in one place an inspector reported that a bee keeper's colonies had been reduced from 145 to 30 because of the infection. The inspectors in all cases report that the diseased bees were destroyed, or treated, as the cases required. Another inspector reported that he found several cases of European or Black Brood in bees that were being shipped into Idaho. Still another reported that he had destroyed 55 stands and another that all the shipments that he inspected were absolutely clean.

It is very evident that the work of the state bee inspection should be placed in the hands of a man who has time to look after the work, and that it should be taken from the horticultural department, which has enough to do in the fruit line. The bee industry in the state has come to be a very important one, and the annual output of honey amounts to a great many thousands of dollars, and the many bee keepers are entitled to more protection than they have had in the past two years. They should have a department of their own and a state bee inspector whose only duties would be to look after the bee industry. 
It is utterly impossible for the horticultural department to carry on this work as it should be done on account of the horticultural interests. I recommend that the work of bee inspection be placed by itself, and maintained as before stated. In closing I wish to thank the bee keepers and the deputies for their work under the adverse conditions of the past two years and to assure them of my co-operation in every way for the betterment and advancement of the bee industry.

The bee inspection work has been allowed $\$ 2,000$ for the two years of inspection and, December 1, of this amount, $\$ 1,346.45$ had been used.

Respectfully submitted,

J. U. MCPherson,

State Bee Inspector. 



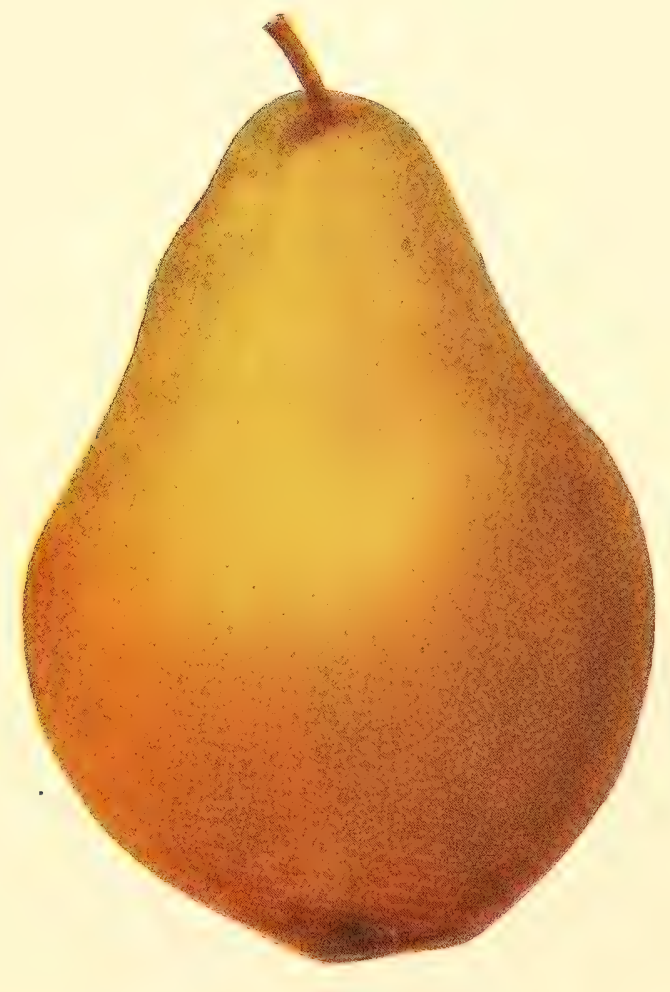

BARTLETT PEAR 


\section{CHAPTER I.}

\section{THE GEOLOGICAL HISTORY OF IDAHO.}

\section{BY J. M. ALDRICH.}

The State of Idaho lies entirely on the western side of the watershed of the Rocky Mountains, and with the exception of a small area in the southeastern part, which lies in the Great Salt Lake Basin, is entirely drained by the Columbia River and its branches, principally by the Snake River. The main mountain system of the state lies along its northeast border, comprising the Bitter Root and a part of the Rocky Mountain chains, which give off several branches extending westward and southwestward into the central part of the state. The Salmon River, rising near the eastern boundary of the state and flowing nearly due west, lies between two extensive mountainous regions. The Salmon River Mountains on its south are among the highest in the state, and they extend in a southeastern direction, merging with the Sawtooth range, which are still higher and comprise the highest peaks in Idaho. These ranges contain the sources of several of the important irrigating streams of the state. East of them are several parallel ranges between which flow Lost River, Little Lost River and some other streams. Along the east line of the state is an elevated region with several small ranges of mountains, which also run to the southeast. Along the south line of the State are two or three still smaller ranges.

The most extensive agricultural region of the state is the Snake River Plain of southern Idaho, which extends almost the entire width of the state. Within the limits of the Great Salt Lake Basin, in the southern part of Idaho, there is a section of comparatively small area, of valuable agricultural land. In the northern part of the state the agricultural land lies mostly rather near to the western border.

From an agricultural or horticultural point of view the 
climate and soil are the principal features of importance. These, however, are directly dependent upon the altitude and other physical features which will be considered in the present chapter.

\section{ALTITUDE.}

The northern part of Idaho, as a whole, has much lower altitude than the southern part, and the southeastern part is highest of all. In southern Idaho the line of 5,000 feet elevation shows very nearly the limit of agricultural possibilities, as the climate at a higher altitude is generally too cold for successful agriculture and the land usually too rough for tillage. In northern Idaho the limit might well be drawn at a lower level, say 3,000 feet. For agricultural purposes little of this land is available, and for horticultural purposes, still less. The only exceptions of importance are the following: In Bear Lake county, which is entirely above the 5,000 foot level, considerable agriculture is carried on in the vicinity of the lake and a little fruit is raised. Another exception is northeast of St. Anthony where alfalfa is raised for a few miles above the limit. In the vicinity of Bellevue and Hailey there is some agriculture and some fruit raising.

\section{GEOLOGICAL HISTORY.}

Many of the features of the different arable regions of Idaho can be best understood by a brief explanation of the geological formation which characterizes them. All the tillable land in Idaho which lies within the Salt Lake Basin was at one time under the waters of a vast fresh water lake, of which the present Great Salt Lake is only a disappearing remnant. This lake had its outlet in a stream which flowed along a channel at present existing, through Pocatello, into the Snake River. From some cause, probably a decrease of rainfall in the regions surrounding the lake, this outlet in the course of time went dry and the lake began to diminish in size, gradually becoming more and more filled up with salt until it 
reached its present condition. That portion of the old ced in the state of Idaho consists partly of almost level bottom land, and partly of a slope situated much higher along the foot of the mountains. These two are connected by a much steeper slope which can scarcely be plowed. The upper slope referred to was originally just below the shore of the lake, in shallow water. It is distinguished at the present time as being a region adapted to dry farming, while the lower level requires irrigation.

In the Snake River Valley there are two quite distinct formations. From Weiser up to the eastern limit of Ada county, and extending still farther east on the south side of the Snake River, is a region which is also the ancient bed of an extensive lake. The shore line of this lake cannot be positively traced along the edge of the mountains as can the one just referred to. How far east it originally extended is unknown. The soil is largely of an alluvial character. It is supposed that this lake was caused by the damming up of the outlet, probably at the time when the Blue Mountains of Oregon were elevated to their present position. This turned back the waters of the Snake River for a period of time, producing a lake in the area described. Ultimately the rise of the waters carried them over the top of the elevation which nature had placed in their way and after this they rapidly wore down a channel through the mountains, thus draining the lake which had been formed. The eastern boundary of this lake will forever remain uncertain from the fact that the entire area east of Ada county was subsequently the scene of numerous eruptions resulting in an outflow of lava which spread in the form of layers of basalt over the central and eastern Snake River Plain almost as far east as the state line. There were several distinct periods of eruption with intervals between, perhaps centuries long, in which shallow layers of soil accumulated. In some parts of this region these eruptions continued until quite recent times, giving to the section west of Blackfoot and Idaho Falls its present character of a rocky desert, which is due to the fact that sufficient 
time has not elapsed since the last outflow to permit of the formation of a depth of soil over its surface. Much of the Snake River Plain, however, has now become so old that an abundance of soil exists and in fact some of the choicest land to be found anywhere is in this very section.

Turning to North Idaho we find two chapters of equal interest. The region of Latah and Nez Perce counties was the scene of volcanic outflows at an even earlier time than those of South Idaho, and to a greater depth. The sheet of basalt at Lewiston is more than 1,100 feet deep, and Lewiston has an altitude of 1,600 feet less than that of Latah county, which would indicate that the latter is underlaid at least along its southern border by a depth of something like 2,500 feet of volcanic material. Lastly, the soils of Kootenai county as far south as the north end of Cœur d'Alene lake were deposited at a much later date, namely, in the glacial period. Then immense glaciers filled those valleys and when they thawed they left them filled to a depth of hundreds of feet with the rocks and other material which they had borne upon their surface in their advance southward. The disintegration of the surface of this mass gradually formed a soil which, by the addition of humus and further disintegration ultimately developed into one well adapted to horticulture. 


\title{
CHAPTER II.
}

\section{THE PHYSICAL FEATURES OF IDAHO.}

\author{
BY ELIAS NELSON.
}

Sagebrush plains, high, snow-capped mountains and timbered plateaus are some of the salient features of the state. In climate it presents all gradations from the high altitudes and short seasons of Wyoming to the mild climate of the Columbia river uplands. The far eastern portion of the state approximates the climatic conditions of the central Rocky mountain states. The Snake river plains extend nearly across southern Idaho as a rudely crescent-shaped area concave to the north. This is an arid region with a gradually decreasing altitude westward and a climate more hospitable to fruits as the western border is approached. It is a vast agricultural region with several million acres of irrigated lands.

The southern border is more or less mountainous. The southeast portion contains a number of short mountain ranges and the agricultural lands here are mostly above 4,500 feet altitude. In the southwest corner lie the Owyhee mountains and their lateral spurs and foothills extend almost to the Snake river.

To the north of the Snake river plains and throughout central Idaho from the continental divide on the east to the Snake river on the west are extensive mountain areas where high altitudes obtain.

The northern part of the state is distinctly humid and more or less covered with extensive forests. Large areas of fine agricultural lands are found here. The altitude is relatively low and though 350 miles north of the Snake river plains the climate is comparatively mild.

Practically the whole of the state is drained by the Snake river and other tributaries of the Columbia. The Snake river rising in the Yellowstone park describes a 
wide curve to Weiser on the western border and thence flows in a northerly direction to Lewiston. This great stream and certain tributaries furnish water for nearly all the irrigation projects in southern Idaho.

Over the southern or arid portion of the state the annual precipitation ranges from 9 to 15 inches and irrigation is a general practice. In the "Panhandle" or humid section there is an annual precipitation of from 15 to 25 inches. Here irrigation is not a distinct necessity.

Differences in altitude and climatic conditions naturally divide the state horticulturally into several distinct regions.

\section{PAYETTE-BOISE REGION.}

We would thus designate the lower Snake river plains and include nearly all of Canyon and Ada counties and portions of Elmore, Owyhee and Washington counties. This is the oldest as well as the foremost of the horticultural sections of the state. The common sagebrush is the predominant vegetation on these plains. There is but little grass and the soil is nearly bare, hence the soil is lacking in humus and nitrogen, a deficiency which is readily corrected by the culture of the legumes. The prevailing type of soil on these plains is a light-colored clay loam with more or less pure clay in the subsoil. This soil though somewhat stubborn at first becomes highly productive when thoroughly subdued.

The annual precipitation ranges from 10 to 14 inches. The altitude is from 2,100 to 2,700 feet.

The horticultural possibilities are varied and the mild climate imposes but few limitations. It should be noted, however, that but few of the more hardy European grapes succeed; also, that conditions favor the production of a prune of exceptional quality. In the apple line it is a region for the Jonathan, Rome Beauty and Winesap which are the leaders.

TWIN FALLS REGION.

The region comprising the plains on either side of the 
Snake river from Bliss to American Falls has much in common with the lower Snake river plains. The native vegetation is the same, the altitude greater, or 3,000-4,500 feet, and the rainfall a trifle less.

The soil on these plains is a clay loam of æolian origin. This dust deposit laid down by the wind is deep, fine, and generally homogeneous throughout. This is the prevailing type of soil in this region.

This is a region of vast and extensive irrigation improvements during the past eight years. Horticulturally its development has just begun, hence the limitations as to varieties and classes of fruits cannot be so well defined. However, owing to the greater altitude and less summer heat commercial orcharding must here naturally be less varied than in the Boise and Payette valleys.

\section{UPPER SNAKE RIVER VALLEY.}

The upper Snake river valley in Bingham and Fremont counties has an altitude of 4,500-5,500 feet. On account of the high altitude, relatively short season and somewhat rigorous climate fruit culture is chiefly confined to hardy fruits such as pears, sour cherries, American plums and quite a varied list of apples. Certain varieties of apples, among them the Winesap, while hardy enough, do not attain sufficient size in this region to be grown commercially.

\section{FOOT-HILLS REGION.}

Under this head may be mentioned certain foothill locations in Washington and Ada counties at altitudes ranging from 2,900 to 3,400 feet where fruit growing is rather more successful than at similar altitudes on the Snake river plains. Such locations are Council Valley, Indian Valley and the country about Sweet, as well as other similar localities. The sagebrush so common on the plains here gives place to buckbrush (Purshia), wild cherry, serviceberry and rabbitbrush. The soils are generally either alluvial or residual and a common type is a clay loam with an admixture of coarse sand. The annual 
precipitation is 12-15 inches, hence irrigation is necessary except where the land is sub-irrigated. The chief commercial fruits here are apples, pears and peaches.

\section{SNAKE RIVER CANYON.}

The Snake river canyon from near Weiser to Lewiston has a climate all its own. Higher temperatures obtain here and at Lewiston the low altitude of 757 feet is reached. At Lewiston and in many sheltered coves along the canyon the European grapes flourish and sweet cherries and peaches find conditions congenial to perfect development. These canyon locations with their light soils requiring irrigation are well suited to the culture of the less hardy fruits.

\section{THE "PANHANDLE" OR HUMID REGION.}

This region is more or less heavily timbered with white and yellow pine and red fir. Tamarack, alder, birch and willows occur on the moister lands and in some localities cedar is found. The wild cherry, serviceberry, wild roses, syringia and wolfberry abound in the forests and on the partially open lands.

The soil on the rolling hills and table lands of Latah county is of basaltic origin while that on the plateaus and gravelly plains of Kootenai and Bonner counties has been formed in ages past by the disintegration of glacial drifts.

From 18 to 25 inches of precipitation falls annually, which amount is sufficient for successful orcharding without irrigation. The altitude is 1,200-2,500 feet which is low as compared with that of the agricultural sections of southern Idaho.

Owing to greater humidity, apple scab which is scarcely known in southern Idaho is quite prevalent here. Not much is made of the prune here and the Winesap apple is not one of the leading commercial sorts, its place with the Jonathan and Rome Beauty being taken by the Wagener. 



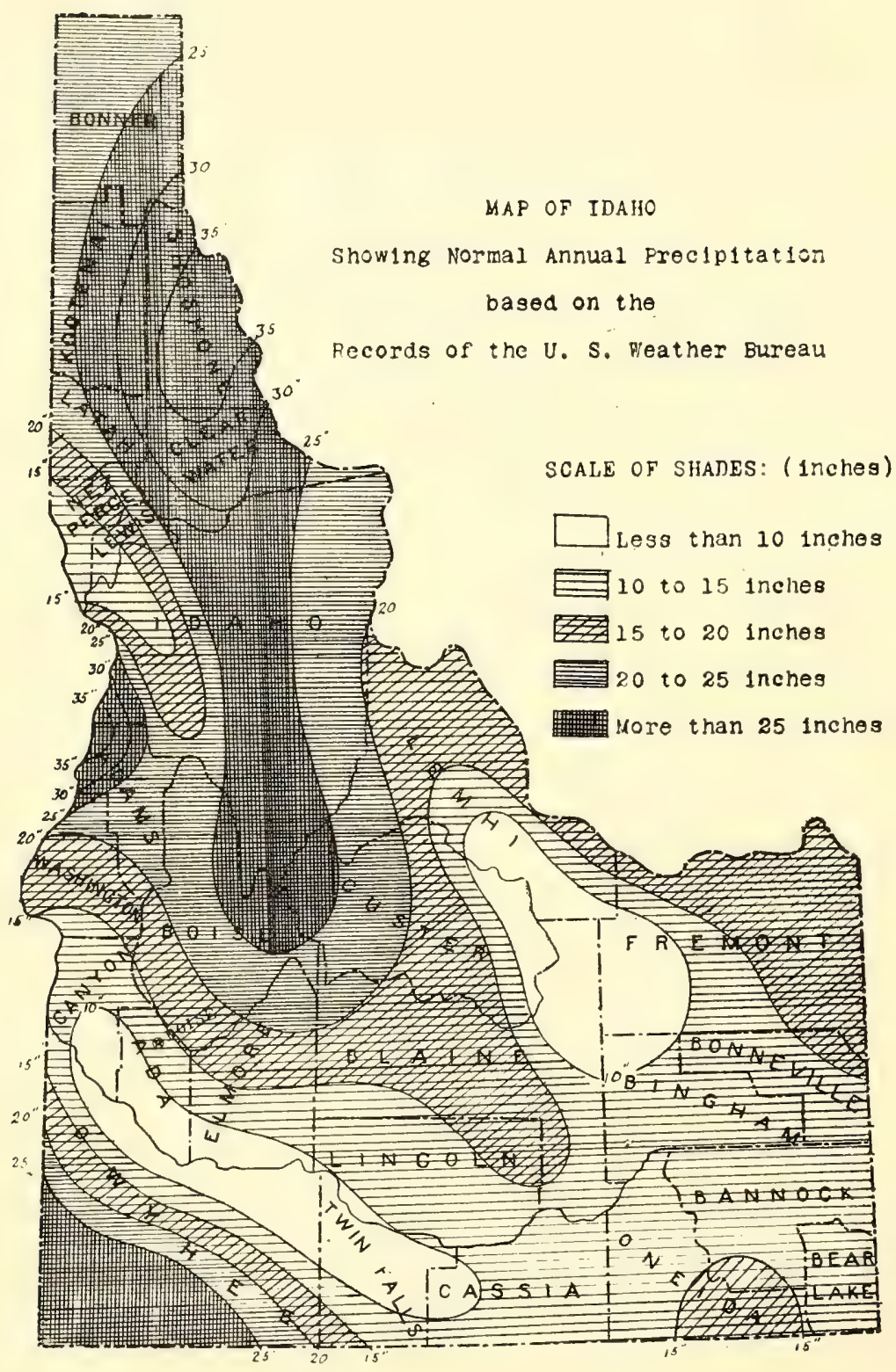




\section{CHAPTER III.}

\section{THE CLIMATE OF IDAHO.}

EDWARD L. WELLS.

Section Director, U. S. Weather Bureau.

Idaho is a state of vast extent and wide diversity of topography. It extends from the 42 nd to the 49 th parallel of latitude, or as far as from Ontario to Georgia; Paris, in Bear Lake county, and Porthill, in Bonner county, are as far apart as Wichita, Kansas and Vicksburg, Mississippi. The altitude ranges from that of central and northern Indiana to more than five thousand feet above the highest peaks of the Appalachian system. Along a portion of its eastern border lie the Cabinet, Cour d'Alene, Bitter Root and Beaverhead ranges of mountains, and a section of the main range of the Rockies, while extending out from these, and lying in every conceivable direction are countless other ranges. The only large area of level land is that which comprises the Snake River Plain, which extends practically across southern Idaho.

The entire state comes under the modifying influence of the equable climate of the north Pacific Ocean, and is protected, to a large extent, from the severe cold waves which prevail east of the great mountain barrier, while in many places Chinook winds play an important part in determining the temperature. The northern part of the state is well within the path of the areas of low barometric pressure that move in from the north Pacific and pass eastward across the country, while the southern part lies well out of that path.

These complex factors go to make such a wide diversity of climate that description is extremely difficult and accurate graphic representation impossible. The normal annual temperature ranges from about 36 degrees in the 
mountains in the interior to about 55 degrees along the middle reaches of the Snake River. This is a range equal to that found in traveling from Moorhead, Minnesota to Fredericksburg, Virginia. The normal annual precipitation ranges from about eight inches along the middle reaches of the Snake River to about 40 inches in the Bitter Root mountains. This is a range greater than that found in going from Albany, New York to Phœnix, Arizona.

Over large areas there is a long growing season and a climate well adapted to the growing of fruit, and there are localities where even tender fruits, such as European grapes, are grown successfully, and such nuts as the English walnut promise good returns. On the other hand, in some of the more elevated sections, freezing weather may occur every month in the year. There are several counties where in one end snow sometimes remains throughout the summer, while in the other, snow enough for sleighing is a rare occurrence.

\section{TEMPERATURE.}

As has already been said, it is impossible to make an accurate graphic representation of any feature of Idaho climate, hence in considering the accompanying charts it should be remembered that they give only a general idea of the distribution of temperature and precipitation but do not portray local conditions.

By comparing the accompanying chart of mean annual isotherms with a topographic map of the state it will be seen that there is a very noticeable relation between altitude and temperature, although this relation is not constant. The coldest part of the state, comprising the area enclosed by the isotherm of 36 , includes a small section in the sparsely settled mountainous regions in the interior. What is said of this area applies, in part at least, to the higher peaks of the Bitter Root, Beaverhead, Seven Devils and Owyhee Mountains. In these sections the climate is characterized by cold, snowy winters and short, cool summers. The snow accumulates to great 
depths in winter and sometimes remains in sheltered places throughout the summer. There are occasional warm periods in mid-day in summer, but the summer evenings are uniformly cool enough to make a fire enjoyable, while frost may occur in mid-summer.

Somewhat warmer than the mountainous regions are the extensive plateaus and high valleys that make up a considerable part of the central and extreme eastern portions of the state. On these plateaus and in these valleys the winters are cold and the summers are short, but still long enough to permit a good growth of grasses and ordinarily of sufficient length to enable the staple grains to come to maturity. The normal annual temperature in this section ranges from 40 degrees to 43 degrees, comparing closely with that found in northern Wisconsin.

The great Snake River Plain of southern Idaho, together with the lower valleys of the streams that join the Snake during its course through this Plain, includes what will soon be the greatest irrigated area in the world. The eastern part of this Plain, together with portions of the country draining into Great Salt Lake, have a climate characterized by moderately cool winters and moderately warm summers. The normal annual temperature of this section ranges from 43 degrees to 47 degrees, which is about the temperature found in southern Minnesota. Here the staple grains, grasses and vegetables find a temperature ideally suited to their needs while in many places the hardy fruits grow to perfection.

The western part of this Plain, together with the lower valleys of such streams as the Big Wood, Boise, Payette, Weiser and Bruneau, have a climate characterized by mild winters and by summers that include some hot days, but in which the nights are ordinarily cool and pleasant. The normal annual temperature ranges from 47 degrees to 55 degrees, and compares closely with the temperature found in Missouri and southern Iowa. In this area there is found a combination of climatic conditions that is highly favorable for the production of apples, prunes, pears, cherries and melons, while in some 
localities peaches, European grapes and English walnuts are successfully grown. There is seldom any damage from winter-killing, and the abundant sunshine during the growing and ripening season, with the crisp, cool mornings of the autumn, combine to produce the finest colored fruits the world has seen.

The northern part of the state, outside of the mountains, consists largely of rolling hills, and has a normal annual temperature ranging from 44 degrees to 53 degrees, which is about the temperature found in Pennsylvania. Its climate is well adapted to the growing of grain and the hardy fruits, and some of the lower valleys, notably in the vicinity of Lewiston, produce abundant crops of the tender fruits. That the climate is adapted to the growing of berries is evidenced by the fact that many species are found in a wild state. It is believed that the marshes along the Kootenai and St. Joe rivers would produce cranberries.

In comparing the temperature of any section of Idaho with that of an eastern state it should be remembered that in Idaho there is less difference between summer and winter and a greater difference between day and night than is found east of the Rocky Mountains.

In discussing climate from the viewpoint of the horticulturist it is important to consider the probability of the occurrence of low temperature at times when the fruit is susceptible to injury therefrom. Fall frosts are scarcely a factor to be reckoned with in the fruitgrowing regions in Idaho, as ordinarily fruit is mature before they occur. But the occurrence of freezing temperature during the period of blossoming and setting is one of the problems to be faced.

A killing frost is one that is destructive to the staple crops of the locality. Just how low the temperature must fall to cause injury to the tender bud, the open flower or the embryo fruit is a question upon which scientists and practical orchardists are alike divided, and is one that depends upon so many factors, such as the condition of the tree, the exact state of the advancement of the fruit, the length of time during which it is exposed to the 
temperature in question and the conditions under which thawing takes place, that it may not soon be answered satisfactorily. In the absence of sufficient data with regard to the effects of spring frosts it is often necessary for the Weather Bureau to take the last date with freezing temperature and call that the date of the last killing frost. Fruits, at least except at the most critical times, will stand a temperature considerably below the freezing point without serious injury. This fact should always be borne in mind when considering tables of killing frost, such as the one accompanying this article.

The problem of preventing injury from frost is being carefully studied by the fruit growers of the state, with such assistance from the Weather Bureau as the limited funds at its disposal will permit. Four things are particularly needed. First, accurate foreknowledge of the occurrence of injurious temperatures; Second, a scientific investigation of the effect of various temperatures at different stages of the fruit; Third, a scientific investigation of the merits of different protective methods; Fourth, an accurate temperature survey of every valley in the state that gives promise of producing fruit. Careful plans are being made to meet the first need. A frost warning service is being organized which, with proper co-operation on the part of the growers and telephone companies, will be of great value. An attempt toward meeting the fourth need has been made by the establishment of numerous observation stations throughout the state, but the small number of stations that can be established and maintained under the present appropriation leaves much to be desired. At present nothing can be done to meet the second and third needs, but it is understood that plans are being made to cover this field.

In short, while the occurrence of spring frosts furnishes the greatest climatic obstacle to the progress of horticulture in Idaho, it is by no means an unsurmountable one. Several peculiarities of the climate of the southwestern valleys are especially favorable for orchard heating. One of these is the fact that the spring frosts are largely the result of surface radiation, and therefore occur 
only on still, clear nights, when conditions for orchard heating are favorable. When there is either wind or cloudiness frost does not occur. Then, too, the temperature seldom goes more than a few degrees below the danger point, and does not reach that point till well toward morning, so that the period of injurious temperature is short.

\section{PRECIPITATION.}

The local variations in precipitation are greater and more complex than the variations in temperature. In the preparation of the accompanying chart showing the mean annual precipitation all available records have been considered, and in the more open portions of the state the actual local conditions are probably very nearly as represented by the chart. In the mountanous regions, however, there are probably many localities where the precipitation is greater or less than the amount indicated by the chart of the general district.

The geographical distribution of precipitation is governed, to a large extent, by altitude, but, as has already been said, it is by no means constant. For instance, Soldier, in Blaine county, and Landore, in Washington county, have about the same altitude. Soldier has an annual precipitation of about 15 inches, while the amount at Landore is about 38 inches. In general it may be said that the precipitation is greatest in the mountainous regions and least on the open plains. The wettest regions includes the Cœur d'Alene and Bitter Root mountains, while portions of the Seven Devils are almost as wet. The dryest portion is along the Snake River in the southwestern portion of the state, while parts of the region of lost rivers and the immediate valley of the Salmon river are very dry, when elevation is considered. The rolling lands and lands in the foothills appear to have a greater amount of precipitation than level lands at the same elevation.

In different parts of Idaho there are many different types of precipitation distribution. Over a considerable 
part of the state the distribution conforms in a general way to the Sub-Pacific type, but there are many local departures from this type. In the Cœur d'Alene Mountains and thence northward the maximum precipitation occurs in November, with a secondary maximum in May. South and west of this area and over a region extending to the southwestern part of the state the heaviest precipitation is in December or January, with a secondary maximum in May. In parts of central and eastern Idaho, the principal maximum is in May or June, with the secondary maximum ranging from November to March. The driest part of the year over most of the state is July or August. From this it will be seen that in those parts of the state where the temperature conditions are most favorable for the production of fruit there is a very light rainfall in the summer and therefore, the various operations of cultivating, spraying, etc., are not likely to be interferred with.

The winter precipitation usually occurs in small amounts, at frequent intervals. What precipitation occurs in summer comes in showers, but the intensity of the rainfall is much less than is found in the state farther south in the intermountain region, and cloud-bursts, so-called, are a rare occurrence.

\section{MISCELLANEOUS.}

Thunderstorms sometimes occur, but they are usually light and of short duration. Loss of life or property from lightning occurs very rarely. Tornadoes are practically unknown. The average hourly wind movement at Boise and Lewiston is about five and one-half miles, while at Pocatello and Idaho Falls it is about eight and onehalf miles.

There is considerable cloudiness in winter, particularly in the western counties, but in summer there is an abundance of sunshine. The average amount of sunshine at Pocatello ranges from about 44 per cent of the possible amount in February to 86 per cent in August. At Boise it ranges from about 33 per cent in January to 87 per cent 
in July. No sunshine records have been kept in northern Idaho, but the record at Spokane, Wash., shows that the amount in that section ranges from about 18 per cent in December to 77 per cent in July.

In this article it has been possible to treat of the climate of Idaho only in a general way. Persons desiring more explicit information are invited to address the local office of the Weather Bureau at Boise.

resuits so int

Table Showing Dates of Killing Frosts at Various Points in Idaho.

\begin{tabular}{|c|c|c|c|c|c|}
\hline $\begin{array}{l}\text { Name of } \\
\text { Station }\end{array}$ & $\begin{array}{l}\text { Average } \\
\text { date of } \\
\text { last killing } \\
\text { frost in } \\
\text { spring. }\end{array}$ & $\begin{array}{l}\text { Average } \\
\text { date of } \\
\text { earliest } \\
\text { killing } \\
\text { frost in } \\
\text { fall }\end{array}$ & $\begin{array}{c}\text { Date of } \\
\text { latest kill- } \\
\text { ing frost } \\
\text { known }\end{array}$ & \multicolumn{2}{|c|}{$\begin{array}{l}\text { Date of } \\
\text { earliest } \\
\text { killing } \\
\text { frost } \\
\text { known }\end{array}$} \\
\hline American Falls .... & Iay $24 \ldots \ldots$ & ept. 13 & July 1 . & Aug. 20 & \\
\hline Blackfoot & May $30 \ldots . . . . .$. & Sept. 10 & July 5 & Aug. 20 & \\
\hline Boise & April $25 \ldots . .$. & Oct. 20 & June 5 & Sept. 24 & \\
\hline Bonners Ferry .... & May $9 . . . . . . .$. & Sept. 15 & May 26 & Aug. 24 & \\
\hline Cambridge & May 20 & Sept. $1 \%$ & June $24 \ldots$. & Aug. 22 & \\
\hline Driggs & June 21 & Sept. 2 & July 13 & Aug. 11 & \\
\hline Grangeville .......... & May $13 \ldots . . .$. & Sept. 29 & May $21 \ldots . .$. & Sept. 17 & \\
\hline Hailey .......... & June 6 & Sept. 13 & July $15 \quad$-. & Aug. 30 & \\
\hline Idaho City .. & June 27 & Sept. 5 & July & Aug. 15 & \\
\hline Idaho Falls ........... & May $21 \ldots . .$. & Sept. 8 & June 20 & Aug. 25 & \\
\hline 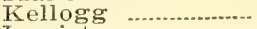 & May 16 & Sept. 17 & May $23 \quad \ldots . .$. & Aug. 28 & \\
\hline Lewiston & April 8 & $\begin{array}{l}\text { Oct. } 28 \\
\text { Sept. } 11\end{array}$ & $\begin{array}{l}\text { April } 29 \ldots \\
\text { June } 22\end{array}$ & $\begin{array}{l}\text { Oct. } 2 \\
\text { Aug. } 25\end{array}$ & \\
\hline $\begin{array}{l}\text { Mackay } \\
\text { Meadows }\end{array}$ & $\begin{array}{l}\text { Mav } 28 \\
\text { June } 18\end{array}$ & Alpt. $1 \frac{1}{29}$ & June 28 ..... & Aug: 16 & \\
\hline 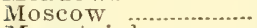 & May 10 . & Oct. 12 & May 30 ....... & Sept. & \\
\hline Mountainhome .... & May 4. & Sept. 13 & May 21 & Aug. & \\
\hline 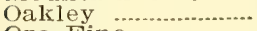 & May 30 & Sept. 17 & July & Aug. & \\
\hline Oro Fino & May 2 & Oct. 11 & June 20 & Sept. & \\
\hline Paris & June 14 & Sept. 5 & July 16 & Aug. & \\
\hline Payette .... & May 8 & Sept. 29 & June 23 & Sept. 14 & \\
\hline Pocatello - & April 24 & $\begin{array}{l}\text { Oct. } 11 \\
\text { Sept. } 12\end{array}$ & $\operatorname{May}_{\text {June }} 13$. & $\begin{array}{l}\text { Sept. } 15 \\
\text { Aug. } 26\end{array}$ & \\
\hline $\begin{array}{l}\text { Salmon } \ldots . . . . . \\
\text { Shoshone }\end{array}$ & $\begin{array}{l}\text { May } 16 \\
\text { May } 5\end{array}$ & $\begin{array}{l}\text { Sept. } 12 \\
\text { Sept. } 21\end{array}$ & May 17 . & $\begin{array}{l}\text { Aug. } \\
\text { Sept. }\end{array}$ & \\
\hline $\begin{array}{l}\text { Shosnone } \\
\text { Sugar }\end{array}$ & May 28 & Sept. 20 & June 28 & Aug. & \\
\hline Twin Falls ... & May $16 \ldots$ & Sept. 27 & May & Sept. & \\
\hline Weston & June $1 \ldots$ & Sept. $12 \ldots$ & June $25 \ldots$ & Aug. 11 & \\
\hline
\end{tabular}





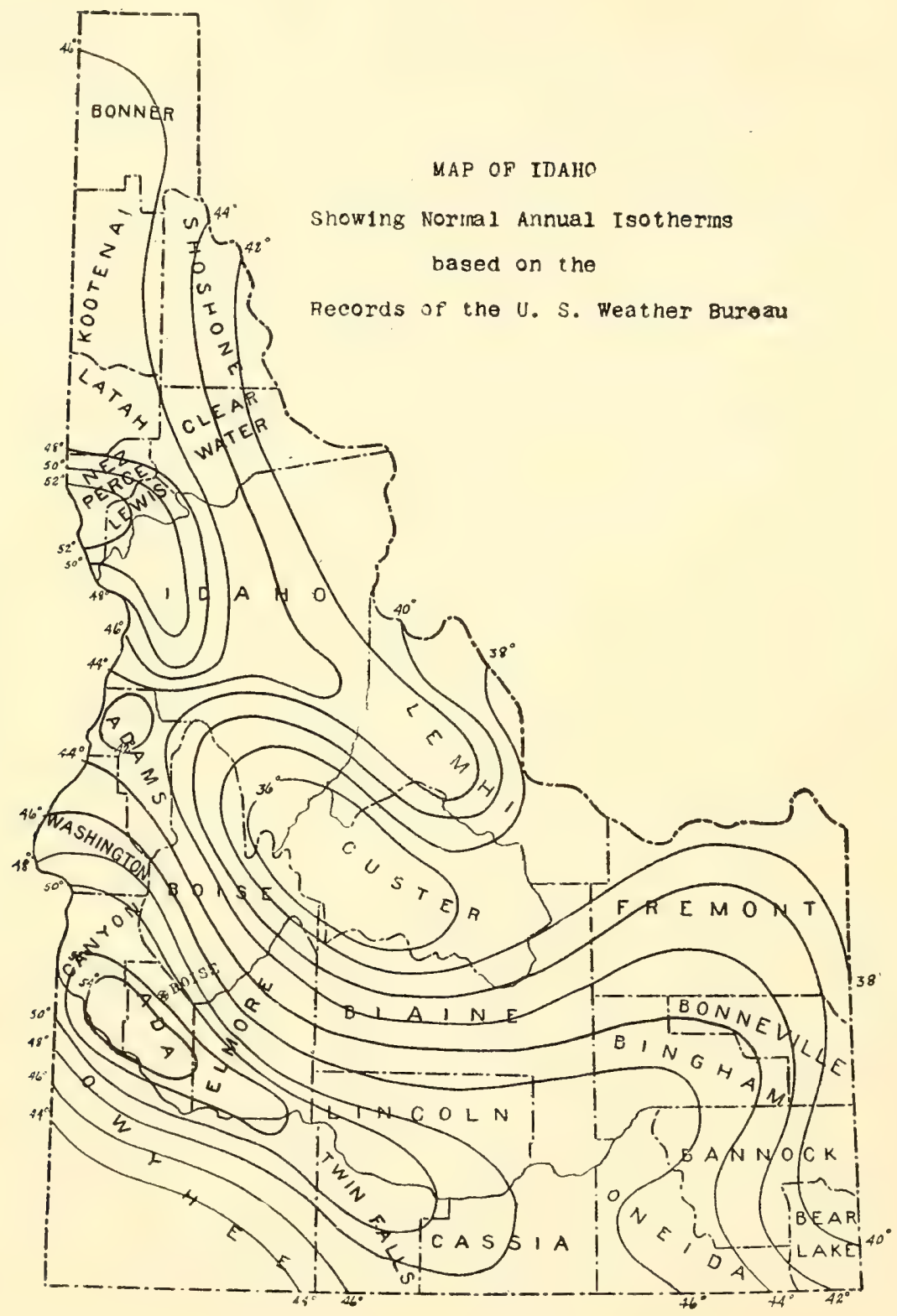









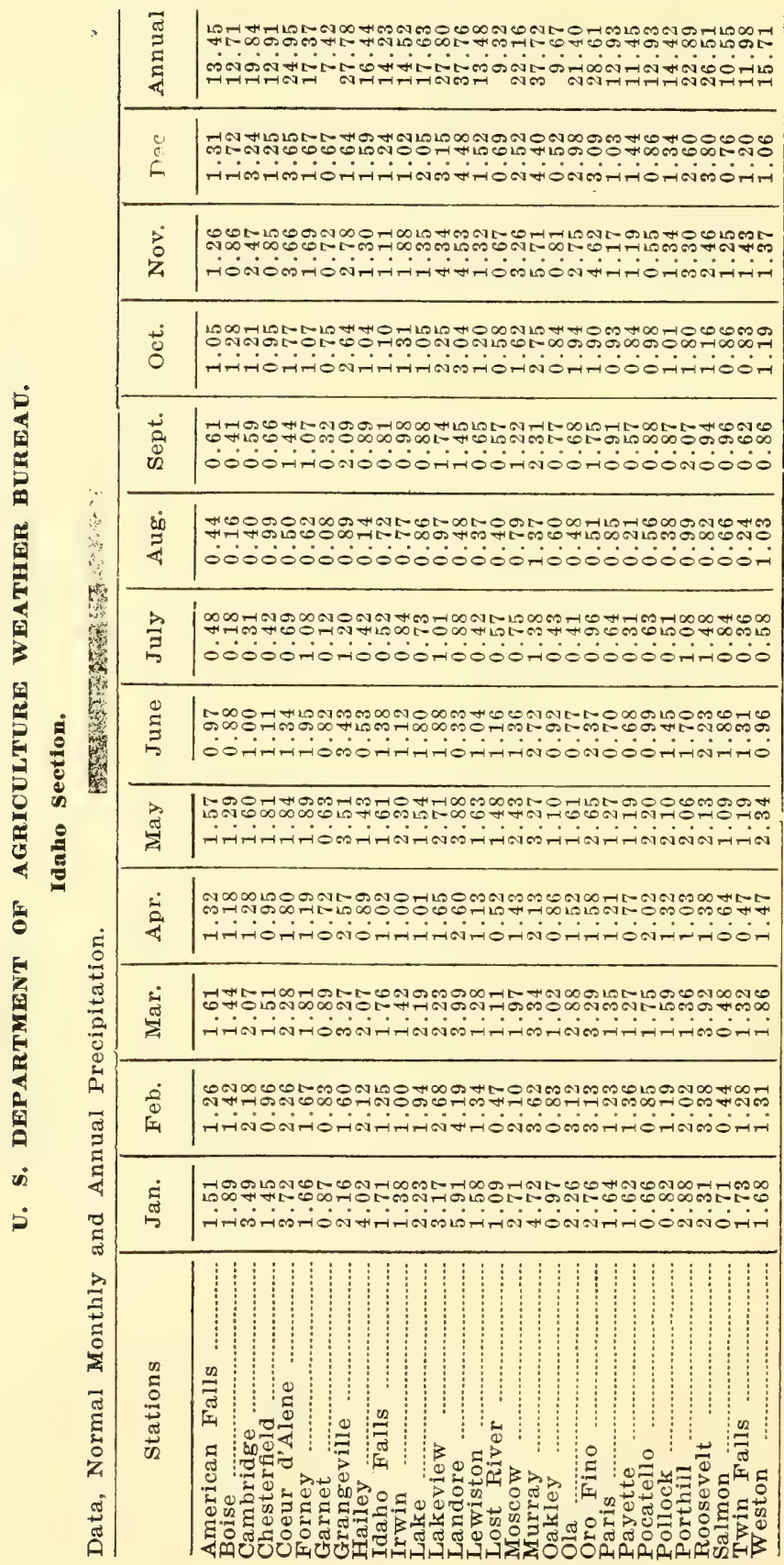


CHAPTER IV.

\section{NATIVE VEGETATION OF IDAHO.}

BY PROF. F. M. ALDRICH.

This subject we shall consider only in its general features, with the purpose of illustrating more clearly and from a different point of view, the probable horticultural resources of the State. The experienced observer forms a rapid estimate of the country over which he is traveling by noting the lay of the land, the appearance of the soil and the character of the vegetation. The introductory chapters of this manual attempt to furnish the same sort of data.

\section{SAGEBRUSH.}

There is no more characteristic plant of the west than the common sagebrush (Artemisia tridentata). Its presence indicates a dry and rather hot summer climate, with too little rainfall to mature the general run of crops without irrigation, except by "dry farming," methods, which have in recent years greatly enlarged the possibilities of this class of lands, and almost make us hesitate to say that any land in Idaho is incapable of raising crops without irrigation. The winter climate of the sagebrush region is in parts mild and in others rather severe. Large, uniform sagebrush unmixed with "rabbitbrush" or other shrubs of nearly its own size, is universally taken as an index of the finest kind of soil for an arid region. Rabbitbrush (Bigelovia, lately called Chrysothamnus) in slight admixture is not very objectionable; more indicates a poorer soil. Greasewood (Sarcobatus vermiculatus) mixed with sagebrush indicates alkali soil.

The sagebrush area of Idaho includes pretty much the whole of the south part, as far north as the middle of Washington county, with an area approximating half the entire state. 
In this region there are a few places where the altitude rises so high as to induce more rainfall, and here the sage thins out and disappears. Above 5,000 feet there is little of the plant.

The only tree that grows in typical arid sagebrush regions is the juniper (Juniperus occidentalis), which occurs scatteringly on the ridges of foothills along the southern tier of counties, and rather abundantly south of the Owyhee mountains and on the lava plain northwest of American Falls. The fine-grained, fragrant and durable wood is used for fuel and fence-posts.

\section{FOREST.}

The forest area of the state extends over most of the northern and central parts, and while this vast region is not all densely forested, it is largely so and the more open spots are not extensive. The principle trees are mentioned below.

Yellow Pine (Pinus ponderosa).-This has a wider range than any other single species of tree in the State, covering nearly all the timber region.

Professor C. V. Piper, in his Flora of Washington, recently published by the United States National Museum, has given a concise account of the habits of this tree. He says: "This tree exhibits a marked predilection for soils of granitic origin, and wherever such soil is found, even if completely isolated, the yellow pine is quite sure to occur. * * * It is apparent that this tree encroaches on the clayey basaltic soils with difficulty. Whether this is owing to the inability of the seedlings to struggle with the herbaceous vegetation or to a lack of adaptation to the soil itself, or to some other factor, remains to be determined. *** From the fact that the yellow pine establishes itself on basaltic clay under favorable conditions of moisture and temperature, as in the Blue Mountains, or of the shading and abundant seeding that the surrounding forests provide in western Idaho, it is evident that the soil factor is not the 
only one that has prevented the spread of the pine forest. Yellow pine forests, where pure, are open in character, and marked by the relatively small amount of forest litter. * * * (They) are, however, seldom pure, except at low altitudes in rather dry soil. In the moister situations afforded by higher altitudes, shaded slopes or valleys, the yellow pine is usually mixed with red fir in varying proportions. Indeed, as the moisture becomes greater, the proportion of red fir increases until it becomes the predominating tree."

Professor Sargent, in his Silva of North America, pays the following deserved tribute to this magnificent tree: "Possessed of a constitution which enables it to endure great variations of climate and to flourish on the wellwatered slopes of the California mountains, on torrid lava beds, in the dry interior valleys of the north and on the sun-baked mesas of the south, and to push out over the plains bodily where no other tree can exist, the advance guard of the Pacific forest, Pinus ponderosa is the most widely distributed tree of western North America. Exceeded in size by the sugar pine of the Sierra Nevadas, it surpasses all its race in the majesty of its port and the splendor of its vitality; and, an emblem of strength, it appears as enduring as the rocks, above which it raises its noble shafts and stately columns."

It remains to add that the yellow pine does not, like the eastern pines, flourish best on sandy, poor soil,but in Idaho it occupies thousands of acres of land eminently fit for agriculture and where not too elevated, for horticulture also.

Red Fir (Pseudotsuga mucronata).-This well known tree has a range but little narrower than the preceding; as already indicated it is limited to slightly higher altitudes and moister locations than the yellow pine is capable of occupying. It generally occurs on steep, rough land, mountains and their foot-hills.

White Pine (Pinus monticola).-Commencing in the northern part of Idaho County and ranging across $\mathrm{Nez}$ Perce into the eastern end of Latah and the southern part of Shoshone; occurring again in the northern part of 
Kootenai about Priest Lake. This tree occupies a much smaller range than either of the preceding, but forms dense tracts of now mature timber of high quality; it is therefore much sought by lumbermen. It is limited in its distribution to areas of much moisture, which may or may not be too rough for agriculture.

There are several other important forest trees in the State, which need not be mentioned for our present purpose.

\section{BUNCH-GRASS PRAIRIE.}

This heading might need a little explanation, as this land has been under cultivation so completely and so long that little trace of bunch grass remains, and the occupants would not know their own farms under this appellation. It is a region along the western side of the state, north of the middle, of small area, corresponding very nearly with the Columbia River Lava of our geological map. It is the principal non-irrigated farming area of the state at the present time and is almost wholly under plow. It is really the upper edge of a tract that lies mostly in the state of Washington, and extends westward in gradually lessening altitude and rainfall toward the Columbia river. It is closely bordered on the east by timber, the yellow pine being generally the contiguous kind of tree.

It is hard to define the limit of "forest" as the timber shades off gradually toward the south. A map would represent some of the lower mountains of the middle and southern counties as having neither sagebrush nor timber. While this is substantially correct as to sagebrush, it should be qualified with the explanation that some timber does occur, often enough to be of great importance to the adjacent communities, yet not enough to be regarded as a continuous body. 


\section{CHAPTER V.}

\section{IDAHO IRRIGATION METHODS.}

\section{BY DON H. BARK.}

Irrigation Engineer in Charge of U. S. Irrigation Investigations in Idaho.

The financial success of the irrigation farmer is largely dependent upon his knowledge of general agriculture, and the adaptability of his irrigation methods.

There are many methods used in the state at the present time. Each one of them has many good features and is best adapted to certain combinations of soil, crop and topography. The best results, however, cannot be secured unless the proper system is used, and it is safe to say that many of our Idaho irrigators could greatly increase their profits if they could be prevailed upon to change their methods of farming.

There are two common methods or systems of irrigation in use, the furrow and the flooding method. The type of system that should be used in each case depends upon a variety of factors, principal among which are: (1) the class of crop; (2) character of soil; (3) topography of the land, and (4) the size of the irrigation head.

The furrow method, generally speaking, is adapted to all rowed crops, such as potatoes, corn and orchard, and to nearly all crops when planted on soils of medium texture.

The flooding method is adapted to grain and hay, or pasture grasses, on nearly all types of soil, and especially to very impervious or extremely porous soils.

The furrow method consists essentially of running the water across the land in small parallel furrows, an equal distance apart, only a comparatively small amount of water being run in each furrow. These furrows or corrugations are made with an instrument somewhat resembling a sled, there being two or more runners or shovels. The corruga- 
tor is drawn by two horses. About five acres per day is the average amount of land covered by man and team with this machine. The furrows should be made after the seed is planted and before it has sprouted. It is usually best to make them run in the direction of the greatest slope, unless it is excessive, in which case they must be run around the slope on a lesser grade. The furrows are made from three to six inches wide, their depth, usually, approximately equalling their width. The character of the soil determines their spacing. They should be spaced such a distance apart that the water will sub across and meet between them in from twelve to twenty-four hours. In medium soils, this distance is usually from two and one-half feet to three feet, in sandy soil from three to five feet, and in fine grained impervious soil, from eighteen inches to two feet.

Where soils are so impervious that the water will not sub across and meet between furrows eighteen inches apart, within a reasonable time, a flooding system should be installed.

Very porous soils should always be flooded, as the corrugation system allows too much loss of water from deep percolation. The corrugation method, as a rule is adapted to rougher land than the flooding system, as the water can be conducted over the uneven places to better advantage with the furrows.

There are many methods of irrigation by flooding, free or wild flooding from feed ditches, without anything to guide the water across the field, and with but little preliminary preparation of the soil; the border method, where parallel dykes or borders fifty to one hundred feet apart guide the water as it floods across the field; and the check or basin method, where small parts of the field are leveled and enclosed by dykes, each enclosure being flooded separately. The greater per cent of irrigation of grain and hay in Idaho is probably now done by the free flooding method. This is a wasteful method at the best, if the value of time and irrigation water are to be taken into consideration, and in addition, less crop is usually produced than with other more careful methods. Where this method is 



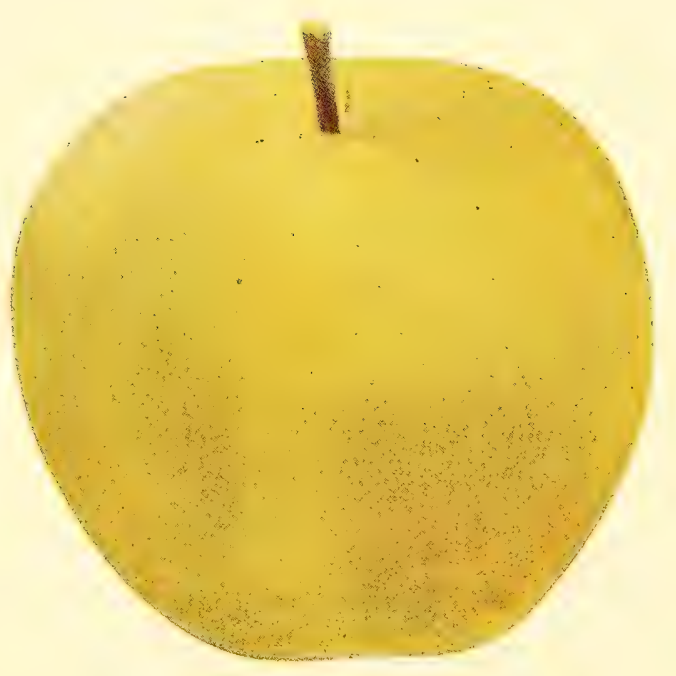

WHITE WINTER PEARMAIN 
used, the land is not usually leveled to any extent, the surface is wetted by flooding haphazardly from ditches that are usually built along each ridge. A given crop on a given soil, during a normal season, requires a certain specific amount of water, in order to make a maximum production, and unless all parts of the field receive this amount, a maximum crop cannot be produced. This fact emphasizes the value of careful preparation of the surface for irrigation, and makes it clear that the best results cannot be obtained by the free or wild flooding method, for even application of water cannot be made to rough, uneven land.

There is an insignificant amount of land irrigated by the check or basin method of irrigation in the state at this time, and it is doubtful whether or not its use should be recommended.

The border method of flooding, however, cannot be too highly recommended for all hay and pasture grasses in Idaho. This method can usually be installed with a reasonable expenditure, permits the use of large heads of water, and is economical of both time and water. This type of system is installed by dividing the field in question into parallel strips or borders, with small low parallel dykes from thirty to one hundred feet apart. These dykes should usually extend down the greatest slope, unless it is excessive, from the head or feed ditch, built along the ridges. These strips should be leveled crosswise, so that the water will spread evenly betwen the dykes, but it is not necessary to make a uniform grade between them, up and down the slope. No more grading is necessary, longitudinally, than will permit the water to flow uninterruptedly without forming pools. The length of these borders between cross ditches should not be over six hundred feet, as it is a waste of both time and water to flood the water farther than this. The dykes separating the borders should be rather broad and low, so that a mower or wagon can pass over them easily. Where the land is well leveled crosswise, dykes six inches high in the center and from two to two and one-half feet wide at the base, are about right. These dykes should be put in before 
the crop is planted, and the same amount of seed should planted on them as is planted on a similar area between. This method is adapted for use with the hay, pasture, and the grains, and cannot be too highly recommended, for it is believed that it is more economical of time and water than any other system that can be installed. Potatoes, root crops, and other cultivated crops, including orchards, are necessarily irrigated by furrows between the rows. The depth of the furrows and their distance apart naturally depends upon the crop. It has been found all other things being equal, that the deeper these furrows are made the less loss there will be from evaporation. The water, with the furrow system, as well as with the flooding system, should not be run too far between cross ditches, and it is believed that about six hundred feet is the greatest distance that should be used. With porous soils, a shorter distance than this would be advisable, for if it is run too far, it has to be held on the upper end next the head ditch so long before the lower end is irrigated, that there is considerable over-irrigation, and loss by deep percolation next the head ditch.

Cultivation has been found to reduce the evaporation losses very materially. This holds true with all cultivated crops, and especially with orchards. From a series of experiments carried on by the irrigation investigation branch of the United States Department of Agriculture, which are described in detail in O. E. S. Bulletin No. 248, it is shown on page 27 that a dry three-inch soil mulch makes a saving of 57 per cent of the water lost from an unmulched surface, and that deeper muches than this make a much greater saving. The same bulletin on page 60 shows the great saving of water that is made by the furrow system of irrigation, over that of the flooding system. Where the flooding system lost 1.25 acre inches during 28 days; there was only 0.99 of an acre inch lost from furrows three inches deep, 0.86 of an acre inch with furrows six inches deep, and 0.72 of an acre inch where the water was applied in furrows nine inches deep.

Orchards should be cultivated as soon after irrigation as the surface soil is dry enough to work properly. The 
length of time after irrigation that this can be done will depend somewhat upon the character of the soil and the weather conditions. With sandy soil, cultivation can usually be done with impunity at the end of 24 hours after irrigation, while with the finer grained soils, from 48 to 60 hours are sometimes required to elapse before the same can be cultivated to advantage. Orchards are many times planted on raw soils, and will do well for the first few years, but owing to the inherent nature of Idaho soils, some cover crop should usually be planted at the end of about the fourth or fifth year, and left to grow for two or three years.

Nearly every type of soil is found in the irrigated sections of Idaho, varying from the finest of adobe clays to the coarsest of gravels. The majority of the soil, however, would be classed as a medium clay loam, finely divided and uniform in chemical composition and texture, to a depth of four or more feet. The annual precipitation throughout the majority of irrigated Idaho ranges from nine to sixteen inches, of which from three to six inches usually occur during the six months of the growing season, from April to September inclusive. This amount of precipitation is not conducive to a great amount of native or natural vegetation, and hence the soil is found to be deficient in humus. This necessitates the addition of manure or the growing and turning under of alfalfa, clover or some other legume, before these soils will produce maximum crops, though very good yields of grain and potatoes are usually produced on raw soils for the first two to four years, after which time it is found advisable to plant clover or alfalfa. The first crop of grain or potatoes, after the land has been in clover or alfalfa for three years, is usually double that produced on similar soils that have never grown legumes or been manured. Average Idaho soil is almost universally found to be very rich in all of the necessary mineral plant foods, but nitrogen must be added sooner or later, if maximum production is to be secured. This can be done in no more economical manner than by planting a legume crop, which will store up nitrogen in the soil while producing a very valuable crop in itself. Alfalfa sod is well 
adapted to the growing of orchards, but this crop should rarely, if ever, be planted in a growing orchard, as it is extremely hard to kill out after the trees have reached a good size. The dead leaves and roots are also a good harbor for pests, and should not be left there permanently. The clovers and the vetches are to be recommended as cover crops for orchards. These produce nearly as much food value as the alfalfa, store up nitrates just as rapidly, and are far easier to kill out.

Vetches have been grown with success on the Gooding Experiment Station. Twelve or more varieties have been tried out on this station, and three of them have been very promising, having made a very rank growth each year for the past three years. These varieties are Vicia Villosa, Vicia Dasycarpa and Vicia Fulgens. These vetches are annuals, and have given excellent satisfaction in every respect. Their nodule development has seemed to be greater and more rapid than that of any other legume grown on the station. These vetches were grown at Gooding at an altitude of some 3,700 feet, and as they have done especially well for three consecutive years, it is quite certain that they can be grown with success anywhere in south Idaho at or below an altitude of 4,000 feet.

From the results of a Duty of Water investigation covering the seasons of 1910, 1911 and 1912, in which hundreds of different fields of all kinds of crops were included, it seems evident that 1.5 acre feet per acre per season will be sufficient for bearing orchards on deep soils of medium texture, if clean cultivation is practiced and a thorough dust mulch is maintained. If cover crops are planted in the orchard, a larger amount of water than this will no doubt be found necessary. Alfalfa has been found to require 2.5 acre feet per acre per season on the better class of soils and it seems possible that an aged orchard with a rank cover crop will require at least three acre feet per acre per season. It is not necessary, however, to plant cover crop on all of an orchard at the same time, and if rotation is practiced, planting the cover crop only on one-half of the orchard at a time, the other half being clean cultivated, the results of the investigation strongly indicate that two acre 
feet per acre per season on the average south Idaho soils of four or more feet in depth will be found sufficient.

The Duty of Water has been found to depend upon a variety of factors, principal among which are, (1) the character of the soil and subsoil; (2) climatic conditions; (3) fertility of the soil, (4) diversification of the crops; (5) use of rotation; (6) preparation of the land, and (7) kind of crop. The effect of these factors on the duty is self-evident, their combined influence is sufficient, in many cases, to double and quadruple the duty. The investigation has emphasized the fact throughout that careful preparation of the soil, and handling of the crop always pay big returns on the investment if the value of the water is to be taken into consideration. There is no question but that a larger amount of water than is actually necessary is being used in many instances throughout the state. Water is becoming more valuable each year, so much so that there is a strong tendency to cut the allotted amount to the minimum, wherever possible, but the investigation that has been carried out will be immensely valuable in determining the minimum amount that will give satisfactory results in each case. The statements of duty that have been made above are all based on deep, uniform soil, and larger amounts will be required where very impervious soils or porus soils are found.

The investigation, as a whole, shows that two acre feet per acre is the proper duty for diversified crops on the best class of Idaho soils, and that most unusual conditions must obtain before one will be warranted in openup a project with less than this amount of water. The largest yields have been made in many cases where the largest amounts of water have been applied, yet the largest yields per unit of water have invariably been made where the smaller amounts have been applied. This emphasizes the fact that the value of the land, of the water and of the crops produced, together with the costs of producing the same, must all be taken into consideration, as well as the amount of water that will produce the largest yield, when determining the economic duty for any project. There is no doubt but that broadly speaking, one 
would be justified in assuming a higher duty of water in places where water is very valuable and land comparatively cheap, than where land is high and water comparatively inexpensive. It is practically as easy, and fully as serious, however, to err on one side as on the other in this matter, and serious consideration of this problem must be urged at all times, in order that stable development may be promoted and that justice may be done to all parties. 


\section{CHAPTER VI.}

\section{PRINCIPLES AND METHODS OF IRRIGATION.}

BY ELIAS NELSON.

Seventy-seven per cent of the area of Idaho lies in the arid belt. With a few exceptions fruit is not grown without irrigation outside the "Panhandle." The irrigated area of the state is nearly $1,500,000$ acres, of which about 140,000 are in orchards. This is about two-thirds the total orchard area.

An annual rainfall of 20 inches is generally conceded as sufficient for successful fruit culture without irrigation under average soil conditions. The depth and retentiveness of the soil as well as the amount of rainfall is a factor in determining the need of irrigation. Fifteen inches of rainfall well husbanded by thorough cultivation has been found sufficient for deep, retentive soils. In certain localities there is a natural underground supply of moisture within reach of the roots. In such places the amount of the rainfall is not of great importance. There are many successful orchards in foothill localities in southern Idaho, where these conditions obtain. A perfect state of cultivation, however, is maintained in these orchards. Another instance of the importance of soil conditions in determining the need of irrigation is found in Nez Perce county. Situated between the high grainbearing table lands and the river bottoms are bench land, where the soil is two to four feet deep and quite retentive of moisture. Here a great deal of fruit is grown without irrigation. On certain parts of the bottoms, however, the soil is somewhat porus and the vineyards and orchards located there are regularly irrigated.

To supply moisture and preserve proper tilth is by no means the least important part of fruit growing. Serious injuries have been experienced in the past by the excessive use of water. That many growers use more water than is necessary, there is no doubt. More frequent cultivation 
and less irrigation has been found to give better results. Those who have learned this by experience no longer use as large amounts of water as formerly, even though the water may be abundant. This tendency to apply less water will result in more intelligent orchard management.

Since the irrigator constantly has to deal with soil conditions, an appreciation of the various phenomena of translocation of ground water is very important. The movements of water in the soil are due to gravity and capillary attraction. Gravity acts chiefly through coarse sand or gravel or any adventitious interstices in the soil. In porus soil the downward movement of the water may be very rapid and the losses great. More frequent irrigations are necessary on soil of this character as a large amount may seep away beyond the reach of the roots. Capillarity comes into play where the soil particles are fine and lie close together. It acts in any direction, upward, downward and horizontally. It aids gravity in distributing irrigation water through the soil and draws moisture up from the subsoil to the surface. During rains and when water is applied the movement is downward. This, however, is soon reversed, so that in the intervals between irrigations the movement is upward. Where the soil is fine and deep capillarity may draw moisture from a depth of 6 feet or more. It is checked wherever the spaces between the soil grains are filled with air; hence, the value of an earth mulch as a cover which more or less completely prevents the escape of moisture. Hardpan may entirely stop percolation and any compact layer of soil may greatly retard it.

In all soils there is a network of interstices among the soil grains. Ordinarily these spaces contain some air, but in a saturated soil all air has been excluded. Without air the roots cannot perform their functions. More water than 80 per cent of the water-holding capacity is detrimental. Forty to sixty percent, or about half air and half water in the spaces in the soil is the condition best suited to plant growth.

The fine volcanic soil of southern Idaho, for instance, has a water-holding capacity equal to 25 per cent of its 



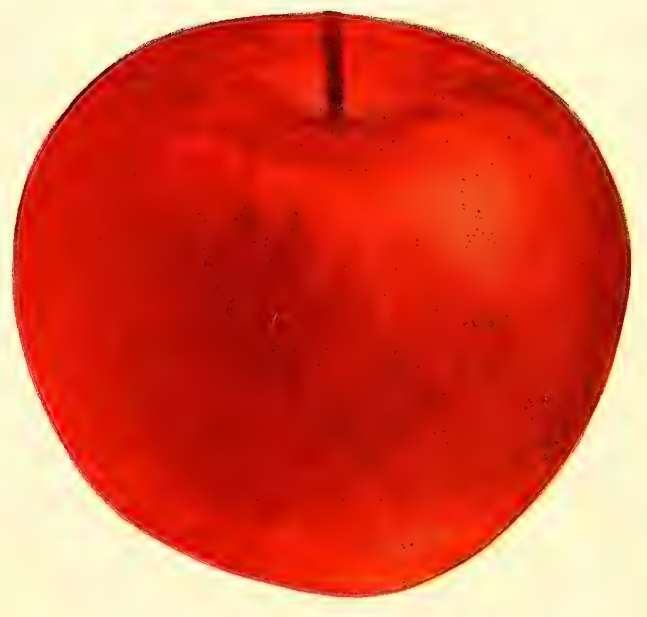

WINNESAP 
weight, while the open spaces comprise 44 per cent of its volume. In this soil the percentage of moisture remains quite constant under irrigation. Sixty per cent of the total capacity or fifteen per cent of the weight is the prevailing amount in the subsoil. It is only for a few days after irrigation that more than this is found, and only when the supply in the subsoil has been too heavily drawn upon that there is less.

A deep, retentive soil is a great advantage. Such a soil becomes a vast storage reservoir which is never quickly exhausted. With proper cultivation the loss of moisture may be reduced to a minimum and a high duty of water thus attained. Water need not be applied as frequently as on shallow soils where the storage capacity is limited. Coarse, leachy soils also require frequent irrigations since much water is lost by percolation.

The use of more water than is required for best results is not only a waste of a valuable commodity, but is responsible for certain injurious effects. When a state of saturation is reached air is excluded, resulting in a temporary checking of growth and interference with proper assimilation. If these conditions are prolonged, serious injury may result. Many orchards have been ruined by the accumulation of alkali, brought by seepage waters from higher lands. When such injuries appear in orchards, there is no remedy other than artificial drainage. Where the soil is shallow and underlaid with an impervious formation, economy in the use of water and thorough cultivation will generally lessen the evils of defective drainage.

In some soils saturation of the surface causes a compacting and cementing together of the soil particles, and the proper tilth is not easily restored. Moisture at the surface serves no beneficial purpose, and is a waste since the water absorbed is almost entirely lost by evaporation.

What the irrigator should try to accomplish is to convey the water to the roots and replenish the supply in the subsoil and in so doing not saturate the surface. We cannot precisely attain this in practice. However, by the use of furrows moderately deep it is possible to handle 
irrigation water in such a manner as not to wet or compact the surface to a great extent. Such a management tends to induce deep rooting, which is desirable.

The furrow system modified to suit the requirement of the orchard is without doubt the best method to use in Idaho. The number of furrows between the rows must be varied to suit the age of the orchard and the character of the soil. Certain soils require five while in some soils two may irrigate thoroughly between rows. A sufficient number should be made so that water is distributed throughout the soil. The roots will then spread evenly. Some growers irrigate young orchards with a furrow on one side of the row. This is not enough nor are two furrows for each row always sufficient. After the first irrigation at the time of planting there should always be at least two furrows and additional ones should be added from year to year as the roots spread. It is important to supply all the roots with moisture and always to keep a furrow in advance of them as they push out into the space intervening between the rows.

Bush fruits will require one or two furrows between rows. Strawberries should have one furrow for every two rows, and in irrigating them, water should preferably be started late in the afternoon, for the soil and water are warm at that time of day. The irrigation may be continued during the forenight if necessary.

To install the furrow system the procedure is as follows: When the conformation of the land permits it, the head ditches are located 300 to 500 feet apart and at right angles to the furrows. When they must be made on contours, they should have a grade of $1 \frac{3}{4}$ to $2 \frac{1}{2}$ inches to each 100 feet and their distance apart be such that the furrows are 300 to 500 feet long. Check boxes are placed in the head ditches at such distances apart that the splash board will raise the water high enough to flow readily into all the furrows. The splash boards are so adjusted that the excess water in each section flows into the next below until the whole head of water is being distributed. Each head ditch below the highest one catches the water from the furrows above it and redistributes it. To divert 
the water from the head ditches small gates or lath tubes are placed in the ditch bank. Spouts $1 \frac{1}{2}$ to 2 feet long made of lath will usually supply sufficient water for each furrow. However, when a larger stream than the lath spouts divert is needed, tubes may be made of half-inch lumber of the proper width. The spouts are placed in the ditch bank just below the surface of the water. When the splash boards are in place the water will flow through the spouts and when any section of the orchard has received sufficient water the boards are removed and the water then drops below the level of the spouts. In porus soil the furrows should be 300 to 400 feet long. In soil that does not absorb water readily they may be much longer and a smaller stream of water should be run for a longer time. The automatic feature of the system and the even distribution of the water which it insures, make it very advantageous. Flooding should never be practiced in orchards, nor should water ever be allowed to come in contact with the trunks of the trees.

The irrigating season in Idaho is from May to August. After the first of September irrigation should cease in young orchards in order that the wood may have ample time to mature. If water is not withheld at that time growth may be prolonged in favorable weather and killing: back may result should a severe freeze occur. The orchard should not go into winter with a dry soil, and unless tolerably moist, water must be applied in the fall after all growth has ceased.

In a deep, retentive soil two to four irrigations a season may be ample, while in shallow soil six applications are not uncommon. The frequency of application and the amount are determined by soil conditions, rainfall and mean summer temperature. A close study of these factors by the grower is essential in judging the need of irrigation.

Irrigation and cultivation go hand in hand, and being so closely related a discussion of the former would not be complete without some notice of the latter. Irrigation cannot take the place of cultivation, for it is beneficial in other ways than conserving moisture, such as opening and aerating the soil. The chief benefit of cultivation and the 
one uppermost in our minds is that of conservation of soil moisture. It has already been pointed out that a dry, loose soil is impermeable to moisture. Hence by keeping the surface well pulverized the connection between the moist soil and the air is broken and the loss by evaporation prevented. Experience has shown that this surface mulch needs to be stirred frequently even though not compacted by rain.

Cultivation also serves to make the soil receptive to moisture. When rain occurs there is little or no run-off in well prepared soil and surface saturation is lessened. As often as tilth is destroyed by showers or irrigation it must be restored. Local conditions must indicate the depth and time of cultivation. In general there should be more frequent cultivation now han is practiced. Some cultivate but once after each rigation. This is not enough. The interval between :aach cultivation should not be more than two weeks and 8 to 15 per season should be sufficient under average conditions.

Growers who practice clean cultivation plow once in spring. This is for the purpose of opening the soil. By cutting the roots that venture too near the surface, it establishes deep rooting. Cultivation alone without any plowing is not a good practice. In heavy soils there is a tendency toward a compact layer just below the depth to which the soil is worked. The use of shallow irrigation furrows often aggravates this condition. Such a compact layer very materially retards the percolation of water. The spring plowing is the remedy for this condition, making subsequent irrigation easier.

The growing of annual crops between the rows for four or five years after the trees are set out is allowable. No crop, however, which does not admit of cultivation, should be grown in the young orchard. After it has reached the bearing age intercropping should have in view the improvement of the soil. The extra water required and the drain upon fertility must be carefully considered. In a few rare cases the soil may be so deep, retentive and fertile, and water so abundant that intercropping may be practiced with comparative impunity. 
Even though Idaho soils are very fertile, the growing of any crop for itself in bearing orchards should be discouraged.

Some growers use permanent and others occasional cover crops. The benefits derived from these crops are the improvement of the condition of the soil by the addition of humus, protection against high soil temperatures in summer, addition of nitrogen and winter protection for the soil. Heavy soils are greatly benefited by plowing under cover crops as the organic matter added makes the soil more friable and more retentive of moisture. The use of cover crops to protect the soil during the hot summer weather seems to have much weight with some growers, and these keep the orchard permanently in red clover or alfalfa. They disc in spring and follow with a smoothing harrow. The first crop is cut for hay while the second is allowed to remain as a cover during the winter. Another practice in much favor is that of alternating a cover crop of red clover kept for two or three years, with clean cultivation for a like period. The idea of soil improvement is uppermost in the minds of those who advocate this system.

A cover crop does not conserve moisture but on the other hand robs the soil of it. Hence, sufficient water must be applied both for the cover crop and the trees. Their use is therefore restricted to those localities where water is fairly abundant.

Green crops plowed under return to the soil those elements of fertility which they take from it, adding organic matter and also nitrogen if the crop be a legume. This is a decided benefit. When, however, a crop is removed, there is a loss which cannot be restored by green manuring. Idaho soils in their virgin state lack both nitrogen and humus. There is thus an obvious need of a cover crop to put the soil in good condition for fruit production. 



\section{CHAPTER VII.}

\section{FRUIT FOR HOME USE.}

\section{T. A. ALLEN, MERIDIAN, IDAHO}

This is a subject of vital importance and one which has been sadly neglected in many localities. Every farmer should plant and take care of a home fruit garden, and no farm is complete without it. The fruit garden should consist of a choice lot of fruit bearing trees and shrubs, maintained for the purpose of supplying fresh and luscious fruits. In its general purpose, then, the fruit garden is intended to accomplish results similar to those of the vegetable garden. In distinction from an orchard, the fruit garden is more restricted in area, it is intended for home rather than for market purposes, and consequently should comprise a much greater variety of fruits.

With the present growth of the commercial fruit interests of the United States the home fruit garden is not receiving the special attention it justly deserves.

Only a few years ago the owners of home fruit gardens not only led in the production of fruits, but were our authorities as to how and where to grow them. Today these gardens, while no less numerous or important, are overshadowed by the orchards where fruit is grown for commercial purposes.

While both the home garden and the orchard are essential to the good of the community, they bear very different relations, to the fruit interests of the country as a whole.

The home garden is always the forerunner of commercial development, and even in those localities where climatic and soil conditions are adverse to conducting such industries on an extensive scale the home fruit garden of the enthusiastic amateur is certain to be found. All the success attained today by the fruit interests of the United States has grown out of the persevering efforts of a few 
men whose home fruit gardens served not only as testing stations for determining the fitness of given sorts for new and untried localities but they were the propagating grounds from which sorts of the highest quality and greatest commercial value originated.

The testing of varieties in new localities and the development and dissemination of new sorts by the amateur is an important work, but the greatest good accomplished by him is to be found in the wholesome influence which he exerts on the community in which he lives.

A community is certain to profit resthetically as well as financially from the influence of such growers, and it is tw them tiat we owe our appreciation for high quality. A discriminating taste developed in a neighborhood creates a demand which it pays to gratify and the amateur who grows fruits for quality will find a ready market in such a section.

The inhabitants of this country are notably a fruitloving and fruit-eating people. Notwithstanding this, however, fruit culture has grown to be classed among the specialties, and few persons who consume fruit are actual growers.

The possibilities in fruit culture upon restricted areas have been very generally overlooked, with the result that many persons who own a city lot, a suburban home, or even a farm, now look upon fruit as a luxury.

This can all be changed and much of the land which is now practically waste and entirely unremunerative can be made to produce fruits in sufficiont quantity to give them a regular place upon the family bill of fare and at the same time add greatly to the attractiveness of the table and healthfulness of the diet. The home production of fruit stimulates an interest in and a love for natural objects which can only be acquired by that familiarity with them which comes through their culture. The cultivation of fruits teaches discrimination. A grower is a much more intelligent buyer than one who has not had the advantages of tasting the better dessert sorts as they come from the tree.

If every purchaser was a good judge of the different 
kinds of fruits, the demand for fruits of high quality, to produce which is the ambition of every amateur, as well as every professional fruit grower, would become a reality. But until some means of teaching the differences in the quality of fruits can be devised the general public will continue to buy according to the eye rather than the palate.

The encouragement of the cultivation of fine fruits in the home garden will do much towards teaching buyers this discrimination. Besides increasing the fruit supply and cultivating a taste for quality, the maintenance of a fruit garden brings pleasant and healthful employment, and instead of proving a hardship, will become a great source of pleasure.

The possession of a tree which one himself has planted and reared to fruit production carries an added interest in its product, as well as in the operation by which it was secured. The unfolding of the leaf, the exposure of the blossom buds, the development of the flowers, and the formation of the fruit are all processes which measure the skill of the cultivator, and when the crowning result of all these natural functions has been attained in a crop of perfect fruit, the man under whose care these results have been achieved will himself have been made happier and better.

Most persons engaging in the cultivation of a home fruit garden will have as their chief aim the production of fruit for the family table and the pleasure it affords; others will go a step farther and find an added source of pleasure in the problems of budding, grafting, cross-pollination and the production of new forms.

In order to prove a source of constant pleasure and gratification a fruit plantation must claim the attention of its grower from early spring to late autumn; its products, portion of the seasons between frosts. The problem presented involves a succession of fruits from earliest to latest, as well as a combination of different species of fruits.

The intensive culture and liberal feeding to be given 
demand that all plants be of type which bear early and heavily in proportion to their size.

As a general rule the following list of varieties do fairly well in Idaho. Summer apples-Early Harvest, White Transparent, Duchess, Red Astrichan and Red June; Fall Apples-Maiden Blush, Wealthy, Tolman Sweet, Fameuse too, must be so planned as to cover the greatest possible and Jonathan; Winter Apples-White Winter Pearmain, Rome Beauty, Grimes Golden, R. I. Greening, Delicious, Winesap and Belleflower; Crab Apples-Transcendent, Yellow Siberian and Hyslop; Prunes, Golden Silver, Italian, French, Pacific, Hungarian and German. Pears-Bartlett, Flemish Beauty, Duchess, Sugar, Keiffer, Seckel and Winter Nelis. Peaches-Muir, Elberta, Early Crawford, Late Crawford, Lemon Cling and Alexander. Plums-Green Gage, Weaver, Wild Goose, Egg and Burbank. GrapesNiagara, Concord, Worden, Moore's Early and Brighton. Raspberries-Gregg, Cuthbert, and Everbearing. Strawberries-Glen Mary, Wilson, Brandywine, Senator Dunlap, Wm. Belt, Jumbo, Gandy and Jessie. Cherries-Early Richmond, Montmorency, Black Tartarian, Royal Ann, Bing, Early Duke, Late Duke. Quinces-Prolific and Champion. Apricots-Montezumet. Nectarines-Boston. Blackberries-Taylor and Agawam. Currants - Cherry, Victoria, White Grape and Black Champion. Gooseberries -Columbus and Downing.

This collection will give you fresh fruit every day in the year if properly cared for. Strive to obtain quality rather than quantity.

The laboring man is entitled to the best there is produced. Why not see that you have it? 


\section{CHAPTER VIII.}

\section{FRUIT BY-PRODUCTS.}

\section{J. SINSEL, BOISE, IDAHO.}

The producing of fruit has claimed the attention of some of our finest intellects-and now we must ask these same men to help in marketing our products. This subject has been one for discussion for years but we are now at the place where we must put our researches into practice.

I have given the by-product end of the industry some thought and the past two years have visited several successfully operated plants, and secured data from the different managers, and will endeavor here to give this information for those interested.

First let us understand that all fruits grown are graded for commercial purposes into three grades, viz.: Extra Fancy, Fancy and Choice, these being the commercial terms used to designate quality, and many a packer has made the mistake of not grading close enough; that is, he would get culls in his Choice, Choice in the Fancy, and Fancy in his Extras, all because he has no other way of disposing of his crop except selling it in its raw state. Now let us see what others are doing and estimate our losses, or what we can save by adopting modern methods. Let us first take the apple, the King of Fruits, and grade it into four grades, viz.: Culls, Choice, Fancy and Extras. Let us pack the Extra and the Fancy for the markets, and be sure that they are strictly up to grade-now by keeping choice and the culls at home we have cut down the quantity and increased quality of our fruit shipments and naturally increased the market price.

Now what to do with the choice and culls that we have on hand is the object of this article. First let us understand that all the equipment necessary to handle $\mathbf{5 0 , 0 0 0}$ 
bushels of apples in one season will cost about $\$ 2,000$, and can be installed in connection with your packing house.

Fifty pounds of bruised wind-falls or decay spotted apples will make three gallons of finished vinegar, and will cost for labor, barrels, handling, selling, 20 cents for the three gallons, and will sell for at least 20 cents per gallon, which leaves a profit of 40 cents per bushel for the fruit that is now wasted, or worse, left in the orchard for the propagation of fruit pests.

Next let us take 50 pounds of the off-color, off-size, ill-shaped, and make them into cider; it will make you four gallons of cider at a cost of 20 cents for the four gallons, all expenses included, and selling at 20 cents per gallon gives you 60 cents per bushel for your better culls, which should never be sold only in the manufactured state.

We now have the choice which are off in color, skin punctures, stings, too large or too small but firm, which we can make into apple butter and jelly. Fifty pounds of apples will make 11/4, gallons of finished apple butter and will cost for labor, sugar, fuel, kegs, or buckets, all complete, 60 cents per gallon, and sell readily at $\$ 1.00$ per gallon, or net 50 cents per box for the apples.

From this grade jelly can be made at the following cost: Fifty pounds of apples will make twenty-four pints of jelly, and will cost for the glasses, sugar, fuel, labor, labels, selling, all complete, $\$ 1.40$ for the two dozen pints and sell readily at 10 cents per glass or $\$ 2.40$ for the 50 pounds of apples, less the cost of production, leaves us $\$ 1.00$ per box for these apples, and when you consider that all of these by-products can be made by yourself in the fall and winter when you are not busy it will give a better profit than I have estimated, as I have taken my figures from plants where everyone received good wages and not personally interested in the financial results. When we know that the complete equipment for a plant capable of handling 50,000 bushels of apples in a winter season can be installed for $\$ 2,000$, why should not every community have by-prcduct plants enough to care for their fruits?

What would this have meant to the growers in southern 
Idaho and Utah the past (1912) season? There were approximately $1,400,000$ boxes of apples grown and at least one-third of these should have been made into by-products, that would have netted the growers at least $\$ 250,000$ and no chances taken, and at the same time reduced the quantity and increased the quality of the fruit shipped, thus assuring us of better returns on what we would have shipped.

In addition to these products, in many of the peach and cherry growing districts, canneries have been built and operated very satisfactorily to the owners of the orchards, and in the prune districts evaporators care for the surplus and culls as well, being used in many places to cure apples, peaches and pears in addition to the prunes. 



\title{
CHAPTER IX.
}

\section{BY-PRODUCTS.}

\author{
BY FREMONT WOOD. \\ President State Horticultural Society.
}

For years I have been urging the utilization of the poorer grades of fruit for by-products. By by-products I mean the enlarged use of the term so as to include evaporation, canning, evaporation of the juices, making jellies and jams, making of ciders, dry and sterilized, cider vinegar, etc.

Our long distance from the markets of the country excludes the possibility of marketing second grade fruits in competition with fruits grown near the point of consumption. The most that we can expect in the near future is a profitable market for our specialties. By specialties I mean our fancy and extra fancy grades of apples and pears and the highest grade of the smaller fruits. This of necessity will mean a large surplus either for waste or utilization by the method above suggested. The apple is a wonderful food product, and everything that will not stand shipment should be utilized by some of these methods. Co-operative marketing must be adopted for the successful handling of our best fruits, and the same methods must be used for the conversion of our poorer class into by-products and the handling and the marketing of the same.

The fruit growers of Idaho and the northwest must understand that the future success of the fruit industry depends first upon the production of the highest per cent possible of fancy grade fruit and the utilization of everything else through the by-product plant.

It has been suggested that the transportation lines prefer handling the green fruit and for that reason discourage plants for evaporation and other methods of concen- 
trating the product. The growers need not fear this situation because the transportation lines will be the first to realize the necessity for the utilization by the grower of his crops upon lines that will continue the business rather than throttle it.

A campaign of advertising our green fruits has already been undertaken, and high grade specialties can be manufactured through all the methods above enumerated. I would not recommend the growing of the fruit with a view of manufacturing it into by-products, but rather for the purpose of producing the highest per cent of perfect fruit. Wherever the utmost care is used, there will always be a considerable per cent for the evaporators, the canning plant and the cider press.

The apples of our northwestern states are very rich in sugar content and with the increasing cost of meats and dairy products the high grade jellies and other products should be placed upon the market at such a price as to involve very extensive consumption and at the same time be a remunerative business to the apple grower. Again it would pay the grower in the end to give away his poorer grade of fruits rather than place it upon the market. The placing of low grade fruit upon the market has such a tendency to reduce the price of his high grade fruit that he is bound to lose money by the undertaking.

My recommendation for the future is to prune severely, thin thoroughly and raise the highest grade fruit possible; market only the fancy grades as specialties and dispose of the balance either through his own or a community byproduct plant. Manufacture nothing in the by-product plant except a product of the highest quality, and when this is accomplished the fruit business of the northwest will be placed upon a substantial basis. 



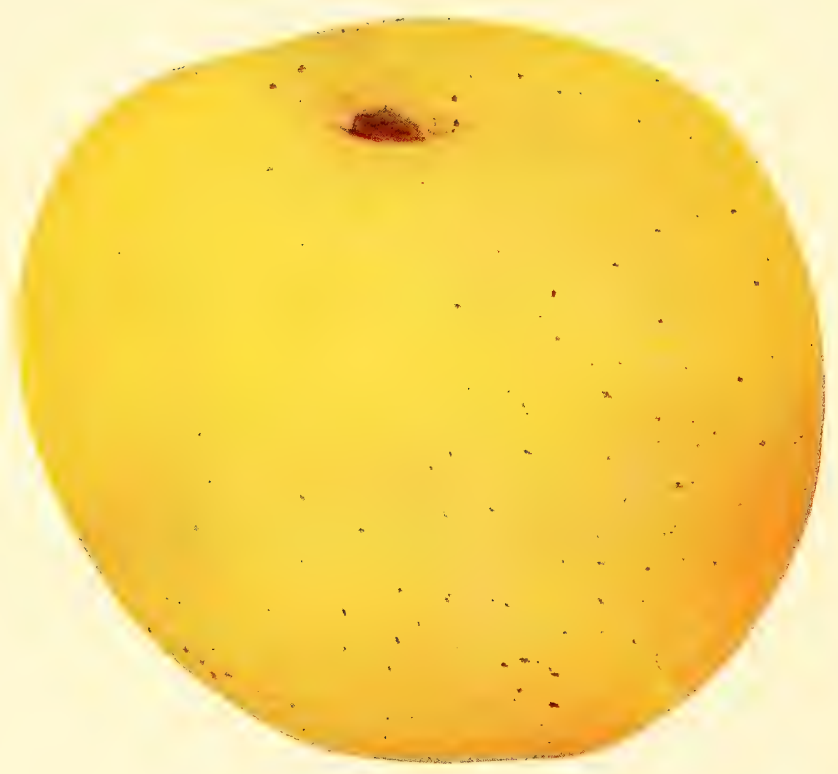

YELLOW NEWTON 
COMMERCIAL FRUIT GROWING IN IDAHO.

\author{
BY JOHN U. MCPHERSON. \\ State Horticultural Inspector.
}

In the past six years somewhere near one-quarter of a million acres of land in Idaho, Oregon, and Washington have been planted to fruit, the major portion of this to apples. The number of trees exceeds 15,000,000. This is about one-fifth of the entire apple growing area in the United States. The estimated value is about $\$ 200,000,000$, and practically every district in these three states, where transportation facilities are available, has its commercial orchards. Not more than 20 per cent of the total plantings have reached what may be termed "in full bearing," and the writer does not believe that over one-third of the whole acreage is five years old or upward. Each year is bringing into bearing a great many thousand acres, and it can easily be seen that the producing area is being added to by the thousand acres each year. To illustrate what this means, it is estimated that the trees in bearing in 1912 will double the yield per car of commercial fruit over the year 1910, which was the banner year of the northwest in fruit production.

From the following figures can be seen the great strides that Idaho has made in the last few years in fruit production when we compare it with the producton of our two sister states. This estimate is based upon the conditions of 1910 rather than upon the present date, and the writer believes that the figures are conservative. The state of Oregon in 1910 had a total acreage of about 106,000 acres, with about 5 per cent in full bearing, and from this acreage 1,900 cars were shipped. Washington, with 115,000 acres, and with a percentage in bearing a little larger than Oregon, shipped something over 5,000 
cars. Idaho with 60,000 acres, and about 15 per cent in bearing, shipped 2,500 cars, which included prunes anc peaches, at a value of over $\$ 2,000,000$. The acreage planted to new orchard since that time has doubled, and at the present time we have something near 120,000 acres in orchard, and each year a large acreage comes into bearing. It is estimated by one of the largest railroad companies in the state that our output in the next five years will be between five and seven thousand cars, or more than double the output of 1910 .

The largest plantings in Idaho, this last season, were in the Twin Falls country, thousands of acres being planted to orchard in Twin Falls and Lincoln counties. There was also a very large planting in the northern part of the state, where, in the five northern counties, the State Horticultural Department inspected over 600,000 trees. Not only in these counties has heavy planting been done, but all over the state, and this last year, several large companies planted many thousands of acres to commercial orchards. The varieties planted vary somewhat according to location and local conditions, as well as the length of the growing season. The varieties that are most extensively raised at this time, and which are bringing the best prices in the eastern markets are the Jonathan, Rome Beauty and Winesap, these being our leaders, although we can, and do, raise many other standard varieties, for, in fact, we raise any apple raised in the northwest. The large planting in the state of 1911 is of standard varieties.

The extensive planting of 1911 brought up the question in the minds of some of the large growers in Idaho as to whether the markets can be overdone with so great a planted area. It is a fact that the states west of the Rocky Mountains will always be called upon to furnish the markets with the high grade commercial apple. According to the statistics of 1910, the output of apples in Idaho, Oregon and Washington amounted to 5,922,000 boxes. This output alone would not supply the cities of New York and Chicago with fruit if it were distributed one box per man per year. And going a little farther into this matter, 
the output of apples of the United States is less than onehalf what it was seventeen years ago. According to statistics for the year 1895, 60,540,000 barrels were raised, and for the year 1911, as estimated, only 30,000,000 barrels were produced, while on the other hand, our export trade has increased. During the year 1897 our export was 505,390 barrels; for 1910 and a portion of 1911; it was $1,721,706$ barrels, or an increase of $1,000,000$ in the past fourteen years. Thus, while the production has decreased, our export trade has greatly increased.

Another great factor in fruit production is that no two districts are alike in all respects. Each district has its marked peculiarities. No variety will grow alike in two districts, and in some instances the dissimilarity is very marked. This condition is not, however, without its value. In the first place it justifies specializing of variety in sections where it has been demonstrated that certain varieties grow to better advantage than others, and it helps to check the tendency of the growers to set out an orchard disregarding circumstances, and to consider instead varieties. which will not only yield better quality, but will be constant yielders year after year. If all the states of the northwest were able to raise the same variety, it would not be but a short time until there would be an over-production of those certain varieties, but there is a great difference in the growing seasons in the different localities in Idaho where apples are produced. The effect of this condition is of great value, and is demonstrated by the fact that no surplus planting of any one variety has taken place to any great extent up to date, but the mixtures such as are now raised have been such as to meet the wants of the trade, and on the other hand it will give the grower the best net returns according to the time and money which he has put into the production of this fruit. It also spreads the time of harvesting and the marketing season over a period of months beginning with the Wealthy apple, which is packed in the Boise, Payette and Weiser valleys from the first to the middle of September, and ending with the Winesap and Rome Beauty, which come in the month of November. 
Taking all of these conditions into consideration, and knowing that the eastern states can never compete with the western slope in apple production on account of their climatic conditions, it can easily be seen that if we hold to our present high standard, and try to better it as fast as possible, that there will never be a time when first class fruit will not be in demand.

There is not a state west of the Rocky Mountains that has a greater future in horticultural work than has th. state of Idaho. We can, and do, produce iruit of size, color and texture that cannot be surpassed in any section. The fruit growers of Idaho today are striving to produce quality rather than quantity, for they know that when we can attain the highest in quality, that the matter of gainng quantity is very easy, and it is certain that within a very short period of years Idaho will be classed as one of the best horticultural states in the west, for both quality and quantity in fruit production.

The year of 1912 marked and will go on record as one of the most remarkable years in fruit production known in the history of the state both in large and small fruits. The number of cars produced last year was 3,775, or an increase of 760 cars over the year 1910, which was the banner year, up to that time, in the history of the state.

This large production of the past year, 1912, has caused the fruit grower to look for more and better markets, both in the United States and abroad. There have been a great many plans advanced as to the best way to create and hold new markets, and many of these plans are founded on good ideas, and if put into effect should be of great benefit to all the fruit growers of the state. No matter what plan may be adopted it must be backed by an endorsement of all the fruit growers of this state, if not by all of the northwest states. It is, without a doubt, up to each and every fruit grower of Idaho to stand behind any good movement that may be advanced in the fruit industry in any of its branches, and all should work together in the raising, packing and grading of fruits, as well as to help with the financial end of any association.

It is one thing to raise products, which you think the 
consumer should have, and another to raise the thing which he wants. The requirements of the consumer must be studied, and then they must be met. When markets are poor and competition keen, it is only the best product which finds a market at any price. When markets are good, high grade products, carefully selected and packed, bring top prices, while poorer grades bring less. It costs no more to raise good crops than it does to raise poor ones.

Careful attention to this question distinguishes the successful fruit raiser from his unsuccessful neighbor. The first step toward creating markets, and holding them, is to raise a product which the market wants. You must be in a position to guarantee that your products are as represented. Without this guarantee it is useless to try and create new markets, much less hold them.

This great production of fruit this past year has been a benefit to all fruit growers of the state in a great many ways. It has shown the need of co-operative effort along all lines of horticulture, and I feel safe in saying that this year will see a great advance, not only along the line of growing what the markets want, but by a combined effort new and better markets will be secured and held for all time to come. 



\section{CHAPTER XI.}

\section{PRUNE INDUSTRY IN IDAHO.}

\section{By C. J. SinseL, National Fruit Judge.}

The title line "Home of the Purple Prune" has rightly been awarded to Idaho, since it is here in the fertile valleys we find this special variety of fruit growing to perfection.

A few years since many of our farmers and horticulturists saw a great future for the prune industry, and as a consequence, several large and a great many small prune orchards were planted. At this time many were disappointed in the returns from their prune crop, since it was a new industry and had not been sufficiently advertised to create a ready demand for the product. After a few years of disappointments many become thoroughly dissatisfied, and cut down or pulled out their prune trees. About this time Idaho prunes had gotten a foothold in the commercial world and in place of being unfavorably looked upon in the market, a demand was created, and this demand has increased annually from that time to this. About five years since a great many realized the error of their former actions and again prune trees were planted in great numbers, and from present indications the men who were fortunate in having land adapted to prune growing and set the same to Italian prunes are reaping a rich reward for their efforts. Prices for fresh fruit have advanced from packing charges to twenty and thirty-five dollars per ton for the fruit at the orchard.

Mr. Horace Day of New York, one of the first men to engage in the wholesale fruit business in that city, stated that the commercial prune was successfully grown in only three districts of the United States, and that of these three, Southern Idaho grew the best. His statement was based on experience he has had in handling fresh prunes from all parts of the world, covering a period of fifty years. It is 
on such judgment that I base my statement that Idaho leads in the Italian prune industry.

In order to maintain this distinction of the commercial prune it is necessary that we follow a few fixed rules that have been worked out by years of experience in specializing in this industry. Some years since it was thought necessary to set every fifth row in the orchard to French prunes for polonization. We have since learned this is unnecessary, and that while the French prune grows well here it does not sell so well in the commercial world. Again, trimming, spraying, and thinning are quite an overhead charge in many orchards; but not so with the Italian prune. When the tree is headed and started in proper form but little, if any, trimming is necessary.

As to spraying up to the present time it has been necessary to spray for San Jose scale only.

As to thinning of its fruit, the prune tree will carry only what it can mature, healthy trees shedding any surplus during the month of June.

Having matured a crop it is the final and essential move to market them. Prunes are prepared in two ways for marketing, namely, packed in natural state, or by evaporation, the first being the most popular form.

When the fruit has gotten its growth, water should be shut off from the orchard, as late watering causes early deterioration and such fruit will not carry well to the eastern markets. At this time permit me to emphasize the fact that many make the mistake of too much water just before or at picking time.

Prunes should be picked carefully, with stems on if possible. This is to avoid tearing the skins of the fruit. The fruit should then be allowed to cool off in the field boxes before packing, then carefully packed in the regular four basket crate. A standard export crate should be $3 / 8$ sides, $3 / 8$ bottoms, $7 / 8$ ends, $1 / 4$ tops and four cleats, all put together with $4 \mathrm{~d}$ cement coated box nails, and for the New York market the Commissioner of Weights has decided that all packages of fruit of any kind whatsoever must have the net weight stamped on the outside, and if the package contains baskets, then the baskets contained there- 



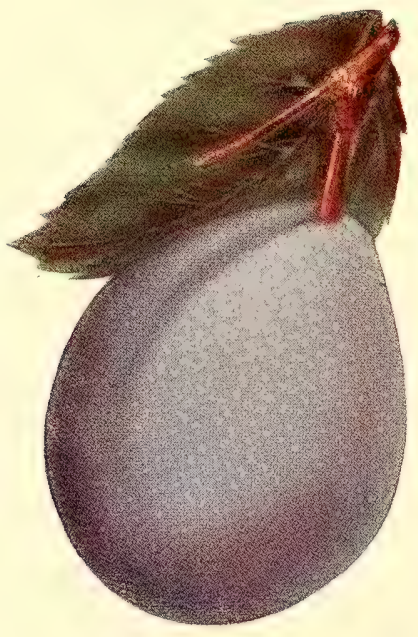

ITALTAN PRUNE 
in must have the net weight stamped on each basket. From this you will see that it will be advisable to stamp the following weights on each package:

Boxes of pears, net weight $40 \mathrm{lbs}$.

Boxes of apples, net weight $40 \mathrm{lbs}$.

Half boxes of pears, net weight $20 \mathrm{lbs}$.

Crates of prunes, plums and grapes $20 \mathrm{lbs}$.

Each basket in crate, net weight $5 \mathrm{lbs}$.

Crates of peaches, net weight $20 \mathrm{lbs}$.

The net weight of all kinds of fruit will have to be followed out on the above schedule. We will say this ordinance is going to be positively enforced, so we ask you to give this matter your earnest attention in order to avoid any difficulties that may arise on the dock if you do not meet the requirements. We do not know whether there would be a penalty or not, but we do know that in order to comply with the law each package must be stamped before it can be sold on that market. However, this rigid rule does not apply to all markets, but the one here quoted applies especially to New York, and since many of our growers ship their cars and divert in transit, it would be well to have every package marked.

\section{DRIED PRUNES.}

Much has been said in former years by way of ridicule of the much despised boarding house dried prunes, but with modern methods of evaporating, the prune has become known as a delicacy and is used by all modern housewives and in the highest class cafes and dining cars. Several methods of curing prunes have been tried and the better ones adopted, so that at the present time the Idaho Italian evaporated prune is not only sought for in the commercial world to be used as of old, namely, stewed prunes, but many are sold as a confection. As the quality of cured fruit advances, so has the price increased, until at the present time well cured evaporated Idaho Italian prunes sell readily at from six to eight cents per pound car lots, f. 0 . b. loading station. This form of marketing prunes is 
annually increasing, and I here predict that in the near future our growers will realize the absolute necessity of providing themselves with evaporators as well as canning plants, with which to care for the imperfect or over-ripe fruit. Such plants could be built for a nominal sum and could be used through which to commercialize many of the by-products of the farm.

\section{SUMMARY.}

After having given twenty years of careful study and close observation to the Italian prune industry of Southern Idaho, I honestly feel that Idaho has a splendid future in this industry, and by carefully caring for the orchards so as to produce first quality fruit as nearly as possible, following the growing in this careful manner by proper grading, and shipping only the fancy in the ripe state, and by treating all other grades by evaporating or canning, a cash market can be built up for this great nationally admired fruit. 


\section{CHAPTER XII.}

\section{EUROPEAN GRAPES IN THE CLEARWATER VALLEY}

BY ROBERT SCHLEICHER.

\section{ADAPTABILITY OF THIS VALLEY TO GRAPE CULTURE.}

It is always a surprise to people unacquainted with the climate of the valleys of the Snake and Clearwater rivers, in Washington and Idaho, to be told that the tender foreign varieties of grapes (Vitis vinifera) grow there in as great perfection as they do either in California, Europe or Asia. This surprise is often so great that it degenerates into doubt, and can be removed only by ocular demonstrations. If one will take the trouble, however, to ascertain what is needed for the production of these varieties, he will find that this portion of the Pacific Northwest possesses those requirements to such a degree as to make it an ideal climate for that purpose.

\section{A QUESTION OF CLIMATE.}

The culture of the grape, being of such great commercial importance over the larger portion of Europe, has received more scientific study and research than any other fruit. Through years of continued observation, French scientists have ascertained the number of degrees of heat and daily mean temperature necessary to cause the vine to leaf out; also the heat necessary to make it bloom, and again the daily mean temperature, and the amount of sunshine required to ripen the fruit. They have found that it is important that for a month following the formation of the seed the mean temperature should not fall below 66 degrees Fahr., that 65 degrees is the lowest at which grapes will ripen, that the mean heat of the period between the beginning of vegetation of the vine to the ripening of the fruit must be at least 59 degrees, and that the most important season is twenty days prior to the ripening of the 
fruit, during which time the mean daily temperature should be 73.5 degrees.

The valley at the confluence of the Snake and Clearwater rivers is therefore compared with the best known grape-growing centers of California.

Count de Gasparino, who is called the founder of agricultural meterology, calls attention to the fact that not heat alone, but sufficient direct sunshine upon the plants is a requisite of perfect fruit ripening. The scope of this article does not allow of printing the comparative tables in full, but from the Signal Service reports we again find that in the number of clear days from April to October, Lewiston is exceeded by only one place in California. If we take into further consideration that, being nearly 10 degrees of latitude further north than the points of comparison in California, the increase length of days during the summer in these valleys gives an average of threequarters of an hour daily more sunshine.

Prof. E. J. Wickson, in his "California Fruits," quoting Tyndall, says that a sheet of vapor acts as a screen to the earth, being in a great measure impervious to heat, and therefore, "it is not necessary that there should be clouds to lessen the chemical effects of sun heat in fruit ripening; not only do clouds intercept sunshine, but watery vapor in the air, when to the eye the sun is as bright as ever, can absorb a large quantity of effective rays and so retard fruit ripening. Hence, an apparently sunny country, which has much invisible watery vapor in the air, may prove defective in fruit ripening qualities." The following table, compiled from the report of the Chief Signal officer, gives the mean relative humidity of the places named from April to October:

Lewiston-Clarkston 48.3

Los Angeles, California 68.8

San Diego, California 74

Sacramento, California 60.9

Fresno, California 49.8

New York City, N. Y. 72.5

Cincinnati, Ohio 67.6

St. Louis, Mo. 80.1 
From the above it is seen that the Snake and Clearwater valleys have the least relative humidity. There is no doubt that to the excessive atmospheric humidity and its neutralizing effect on the sunlight, together with the lack of sunshine, is due the failure of the foreign varieties of grapes in the Atlantic states.

Now, having shown that this climate possesses in an eminent degree all that is needed to make it perfect for grape-growing according to the requirements based upon researches of scientists, should any of these be fallacious or open to doubt, the fact remains indisputable that we produce in greatest perfection, not only the grapes that thrive in middle Europe, but those originated in Spain, Italy, Northern Africa and Asia; and we have no less authority than that of Colonel Brackett, Pomologist of the Department of Agriculture, who some years ago traveled out of his way to assure himself that grapes which were exhibited as Idaho grapes were really grown in Lewiston valley, and stated that after an exhaustive inspection of California vineyards, a few weeks previous to his visit, he had seen nothing there to excel, and little to equal, what he saw here.

VARIETIES FOR DIFFERENT PURPOSES.

The early plantings of grapes in this valley were mainly of Sweetwater and other Chasselas varieties, and Black Hamburg. While all of these, and especially the latter, are deservedly favorites for home consumption and shipment to near-by markets, their planting in the future is not to be recommended on any extensive scale. Commercial vineyards should be of those varieties which, besides being large and showy, have good keeping qualities and are hard enough of texture to stand shipment to distant markets. The best known among them are:

The Flame TOKaY. While not of high quality, is of such large size, both in bunch and berry, and so attractive in appearance, and such a good shipper as well as immense bearer, that it has become the leading table grape shipped from California to eastern markets, where it outsells all 
other grapes. It colors and ripens remarkably well here, especially in elevated situations. Next in importance we would place the

WHITE MALAGA. A very strong grower and heavy bearer, with good sized bunches of large berries, which, owing to the looseness of the bunch, is a better keeper than the Tokay and fully as good a shipper, but, not being so attractive in appearance, does not command quite so good a price.

RAMMONIA OF TRANSYLVANIA. A late importation from eastern Europe which has proved itself a great success in the Snake and Clearwater valleys. It is a dark blue grape of immense size, not quite so good a shipper as the two foregoing, but which outsells all others wherever it has been marketed in the last few years. This variety is not grown in California to any great extent, probably because it was not introduced there, but has attracted more attention to the grape-growing possibilities of this section than any other variety.

EMPEROR. A large black grape of good shipping qualities, which has proven very unsatisfactory in some parts of California, and highly satisfactory in other parts; has been grown here for a number of years very successfully.

MUSCAT OF ALEXANDRIA. This is the only grape tried here which does not yield full crops regularly, owing to "coulure," or dropping off of the berries at blooming time in some seasons, yet is very valuable in locations where it thrives. It seems to do better on sandy river bottoms than on higher ground.

ROSE OF PERU. While it ripens with the earliest, will hang on the vines until winter, and resists the damage done by the fall rains better than any others; is worth a place in any vineyard. It is not adapted to long shipment.

BlaCK CORNICHON. Has come to the front in the last few years in California as a leading late-shipping grape. It is successfully grown here and will likely prove of good value.

The list of good varieties which can be grown successfully here is not by any means limited to the above, but they are the ones that have been planted most extensively 
and have proven profitable. The writer has a collection of over fifty varieties on trial, from the hardiest grown in northern Europe to those originating in southern Europe and Asia, and a number of them have merits which make them deserving of more extensive planting. Notable among these is the Hunisa, a variety the cuttings of which were sent to the Department of Agriculture by a missionary from Aintab in Syria, in 1902, and reputed to be the best keeper of any grape known, being usually kept in good condition until March at its native home. This reputation is likely to be sustained in this climate, as far as one can judge from two year's observation.

\section{§OIL, EXPOSURE, METHODS OF PLANTING, CULTIVATION,} TRAINING, PRUNING, ETC.

The different soils of this valley, from the sandy river bottoms to the loamy hillsides, have all proven themselves good for grape culture, and different analyses show them to contain in proper and liberal proportions every element required to grow abundant crops for many years to come without the aid of fertilizers. The vine, however, appreciates good, deep soil and will grow and bear fruit in proportion to its supply of it; and there are hillsides overlooking both the Snake and Clearwater rivers, overlaid with several feet of good, loose soil, rich in humus, a given area of which will probably, year after year, produce twice as much as poorer lands having but a few inches of vegetable soil overlaying the hard-pan. The hillsides, besides having richer soil, have greater immunity from late spring and early fall frosts, and will no doubt prove the choice locations for future planting wherever water for irrigation can be brought onto them.

Plowing to the depth of 12 to 15 inches will be sufficient preparation for vineyard planting on the sandy bottom lands, but on the higher lands where the subsoil is harder or underlaid with clay, following the turning plow with a subsoiler and thereby loosening the soil to the depth of 20 inches or more will be found to prove a decided advantage, the good effects therefrom being appreciable for eight or ten years after planting. 
Either cuttings or rooted vines can be used for starting a vineyard, but while the latter cost several times as much as the former in cash outlay, when the uniform stand and more satisfactory growth of the rooted vines is considered, it is good economy to use them. There is quite a difference of opinion as to the distance to leave between vines and rows in planting a vineyard, but usually more room is given now than formerly. For strong-growing varieties of table grapes, such as those named above, we would advise planting in rows, vines 8 feet, and the rows 8 to 10 feet apart; the latter distance if it is expected to use two horses in cultivating.

It is preferable in this climate to plant the rows north and south wherever practicable, as a protection of the crop from sunburn during the extreme heat of July and August. If, however, this is impracticable, the greatest care must be used not to do any summer pruning on the south side of the rows.

It is advisable to use water in the holes in which the vines are planted, and if a good growth can be secured by cultivation alone without any more watering the same season, and even during the second one, the vines will develop a much better root system by striking deeper into the soil.

It is a difficult and lengthy matter to lay down rules for pruning a vineyard, the scope of this article will not permit of it; but we might say to the intending planter of a vineyard that his knowledge of pruning will grow along with his vines if he will only give the subject careful thought and observe the practice of others.

\section{IRRIGATION.}

Irrigation of vineyards, and the amount of water needed, is a local and specific question, and depends upon the following two conditions, which are: The amount of the seasonal rainfall, and the character of the soil and subsoil and its retentiveness. River bottom vineyards with loose, gravelly subsoils may need three or four irrigations a year, while side-hill plantations in loam with clay subsoil may raise a good crop with one irrigation, but with 



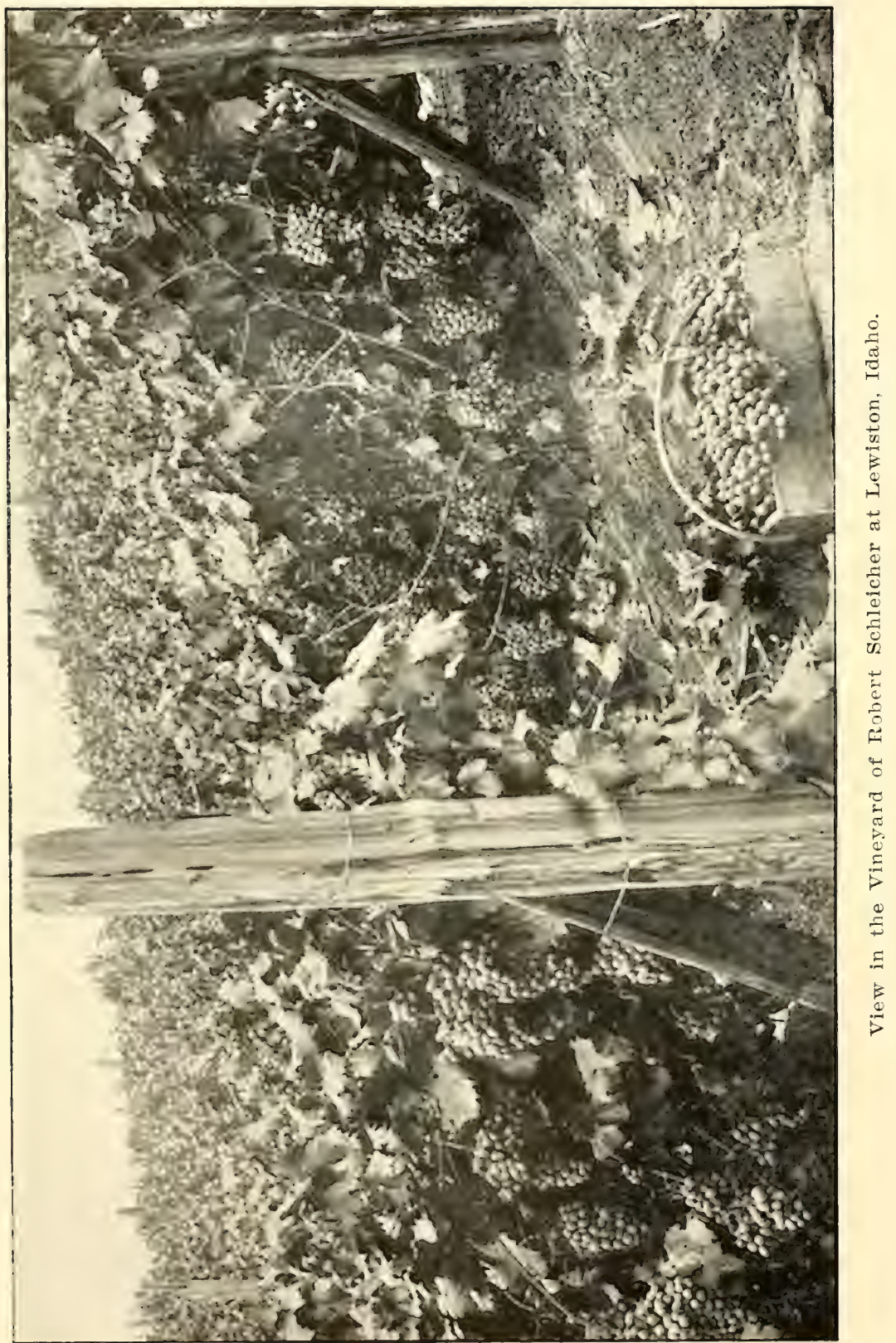


thorough and timely cultivation implied in both cases. It will be safer to state, from results obtained from practical experiments made here covering some twenty years, that an acre-foot of water, added to the rainfall, will be more than ample to secure a bountiful crop and keep the vines in the best of condition. This is about the amount of water, from 25 to 30 inches a year, that falls in the countries which are considered the most fruitful in the world, with the advantage in this instance of the irrigation water being applied at the very time when it is needed, with very little waste by evaporation as compared with that which takes place when all the moisture is supplied by rainfall. In locations where water is plentiful in winter and scarce in summer, winter irrigation of vineyards has proven a great success; a thorough soaking of the soil during the dormant season, followed by good cultivation during the period of growth, with possibly one irrigation in July just before the ripening of the fruit, has given better results than several irrigations during spring and summer.

\section{MARKETS AND MARKETING.}

The supply of grapes grown in this valley having been limited up to the present time, the market has been restricted to near-by towns and cities, and while grape growing has been fairly remunerative, the profits to the grower will increase as the acreage planted in the valley becomes larger. The difference in transportation charges alone between express rates which the grower pays now, and car-load rates by freight, which he will pay when there are car-load lots to ship, is in most cases enough to make a difference of $\$ 150$ per acre a year in the net profits. The demand for good grapes, covering a season of three or four months, is limited only by the supply of a good article, and, with transportation charges as low as those given California growers, this valley can claim the whole United States for a market.

This section has suffered in the past, and is suffering yet, from unjust and discriminating express and freight rates, allowing California to lay down her products in the 
markets of the northwest at rates denied to the local growers. The attention of those in charge of making these rates has been called to their unfairness, and relief has been promised for the future. With all-rail communication bringing Lewiston-Clarkston within 12 to 14 hours of Portland and the Sound cities, as against 40 and 50 hours to the same places from grape growing points in California, it is but fair to assume that whenever this valley produces large enough quantities to supply those markets, freight and express rates will be made which will remedy the present most unequal conditions.

\section{WINE-MAKING.}

The experiments in wine-making, conducted here for some years, have resulted in notable success; the dry wines of the Sauterne and Rhenish types having been pronounced by connoisseurs as coming nearer to the European wines than any grown in California. It has been known for hundreds of years that the best wines were produced near the northern limit of possible grape culture and mostly on the slopes overlooking large rivers. These conditions are met in an ideal way in the Lewiston-Clarkston valley.

Wines produced here were given high awards at Buffalo, St. Louis and Portland expositions, and no less an authority than the late Prof. George Hussman, of Napa, California, for forty years the leading writer in the United States on grape growing and wine making, and father of George C. Hussman, the present Pomologist in charge of viticultural investigations of the United States Department of Agriculture, writes under date of May 15, 1902, concerning a bottle of Idaho Sauterne sent him for his opinion: "I called in the best judge of wines we have here. We tasted it together and pronounced it a very good wine, equal to the best wines made in this county (Napa), which we claim makes the best dry wines in the state. It is a good sound wine which ought to sell anywhere among wine drinkers of the right sort; wine which makes glad the heart. At my age (74) it is highly gratifying to me to 
find that my efforts since 1850 in the cause of grape culture and the making of pure wine have not been in vain."

As these wines were made from grapes which have more of a reputation for table use than for wine making, and as none of the makers had any previous experience in wine making, in other countries, and as the encouraging results so far are due entirely to soil and climate, there is justification for the belief that when wines made here within the last two years, from grapes used in making the celebrated growths of France and Germany get age enough to develop their highest quality, there is a possibility of results that might realize the most sanguine hopes. At all events there is a splendid field for intelligent experimentation in this line, and it may not be too visionary to dream of the slopes and hillsides of the Snake and Clearwater rivers being in the near future covered with thrifty vineyards, drawing on the accumulated fertility of the past ages, and transforming it into wealth, as have those on the hills of the Rhine and the Moselle, the Rhone and the Garonne, the quality of whose products has inspired poetry and song for the past thousand years, and made them the wealthiest sections in the world.

From an economic standpoint, the business of growing table grapes and that of wine-making go hand in hand, and every owner of a vineyard of any size should be prepared to take care of at least a small portion of his crop by pressing it into wine; or, if he has conscientious scruples in the matter, manufacturing unfermented grape juice, which has lately become an article of almost general consumption.

Upon this, the moral side of viticulture, F. T. Bioletti, Assistant Professor of Viticulture in the University of California, who lately returned from a prolonged sojourn abroad on behalf of the viticultural interests of the state of California, made the following remarks before the State Farmers' Institute at Berkeley a short time ago: "No satisfactory reason has been given why the nations of southern Europe are more temperate than those of the northern countries, except that they drink wine instead 
of ardent spirits. Drunkenness, which is the curse of the country districts of England, Germany and Scandinavia, is almost unknown in Spain, Italy and southern France, especially in the wine-producing districts. $\mathrm{My}$ contention is not that wine will not intoxicate, but statistics prove that wine-drinking and sobriety go hand in hand, and whether or not wine has any direct influence in the cause of temperance, it certainly has no influence in the contrary direction. Anything which can be said against the use of wine by healthy, normal, human beings can be said with far more force and truth against the use of tea, coffee, or any of the numerous articles of our ordinary diet which, in excess, have deleterious effects."

DISEASES OF VINES, PHYLLOXERA AND RESISTANT STOCKS.

Grape-vines have been remarkably free from disease in this valley, mildew having so far made its appearance only for a season or two and having readily given way under the application of ground sulphur once or twice during the season.

The much-dreaded phylloxera, which has raised such havoc in the vineyards of Europe and California, has fortunately not been brought here yet, and, if proper care be taken not to import any vines from districts infected with it, it can forever be kept out. The laws governing the importation of nursery stock into both Washington and Idaho, if properly enforced by the Fruit Inspectors of the several districts, will be ample protection. If, however, in spite of all precaution, it should make its appearance in this valley, recourse would have to be had to what has proven the most successful method of combatting it, the planting of resistant vines. A resistant vine is one which is capable of keeping alive and growing even when phylloxera are living upon its roots, and some of the wild vines growing in the Mississippi Valley have this quality. The fruit of these vines is, however, so undesirable, that recourse must be had to grafting upon these roots vines of the varieties wanted, and thus use them only as stocks. This makes the initial cost of raising a 
vineyard several times as high as when vines can be raised on their own roots. In spite of this increased cost at the beginning, it would be true economy to plant new and extensive vineyards with resistant stocks but for the following reasons: While the European vine (Vitis vinifera) is remarkable among cultivated plants for the wide range of soils in which it will succeed-ranging from the lightest sands to the heaviest clays, from dry hilltops to low, moist plains-this is not the case with the resistant stocks. Some are suited to rich, moist soils, others only to dry, rocky ones. Again, there is a lack of affinity between the Vitis vinifera and some resistant stocks, certain varieties doing well on some stocks and refusing to bear on others. This leaves an intricate problem of adaptation and affinity to solve for each different locality, and, until this is done in a thorough manner, it would be too expensive and risky to make large plantings with resistant stocks. Under the direction of the Experimental Station of the University of Idaho, the writer is at present testing ten different kinds of resistant roots, also some grafted vines upon different stocks. These were procured from the University of California, with the kindly assistance of the viticulturists of that institution, selections being made which, from their experience, would be most likely to prove successful in this locality. These experiments, when completed, with others which are contemplated, will in all probability give the knowledge necessary to put the vineyards of the valley upon the best possible resistant basis, if there should arise the necessity for it in future years. This necessity need not arise, however, if planters will procure their vines and cuttings from the vineyards here already in bearing, which are free from disease, and from which a list of varieties ean be selected including the leading and best for the different purposes.

FUTURE OF THE TABLE GRAPE BUSINESS.

The Secretary of the California Fruit Shippers' Association, in his report at the close of the very prosperous 
season of 1905 , calls particular attention to the increased demand in the eastern states for California grapes at good prices, and recommends the planting of larger acreage to keep up with the expanding markets.

In a late interview by the Sacramento Bee, Mr. A. B. Humphrey, a prominent grape-grower and shipper of Sacramento county, just returned from a four-months' tour of the eastern and middle western states, where he went for the purpose of studying the grape market, methods of handling the crop, of diverting cars in transit and the conditions that must prevail to continue the splendid prices of the past seasons, says that he has returned stronger than ever in the belief of the impossibility of overdoing the table-grape market.

In fact, the market for Tokays, Mr. Humphrey says, is practically in its infancy, so far as concerns the grower of Tokay of superior quality and color. It is the attractive color, the deep, rich crimson, that dealers first look for, and the Tokay that has this essential characteristic necessarily has the flavor. Mr. Humphrey expressed surprise at the large number of eastern cities whose markets have never offered a California table grape for sale.

Now, as every condition which works for the extension of the table grape industry in California applies as fully to this valley, both as regards the production of a superior article and the expanding markets, it is evident that no more profitable use can be made of every acre of land than planting it to choice table grapes, wherever the climatic conditions meet the necessary requirements.

In this connection we might add that a grape exhibit from the Lewiston-Clarkston valley at the St. Louis Exposition in 1904 got as high an award as California, the coloring and flavor of the Tokays being admitted by California exhibitors to be equal to the finest their state could produce.

A display made by a grower* of this valley at the Portland Fair, 1905, in competition with California,

* This was Mr. Robert Schleicher.-[Ed.] 
brought forth a letter from Prof. H. E. Van Deman, ExPomologist of the Department of Agriculture, and President of the Horticultural Jury at the Lewis and Clark Exposition. He wrote: "No doubt you have received the notice of what I awarded you, and I wish you could have had more than one gold medal, for you deserved it. You made the best grape display at the exposition. I was much pleased with the crispness and good flavor of some of the grapes you sent," etc., etc. 




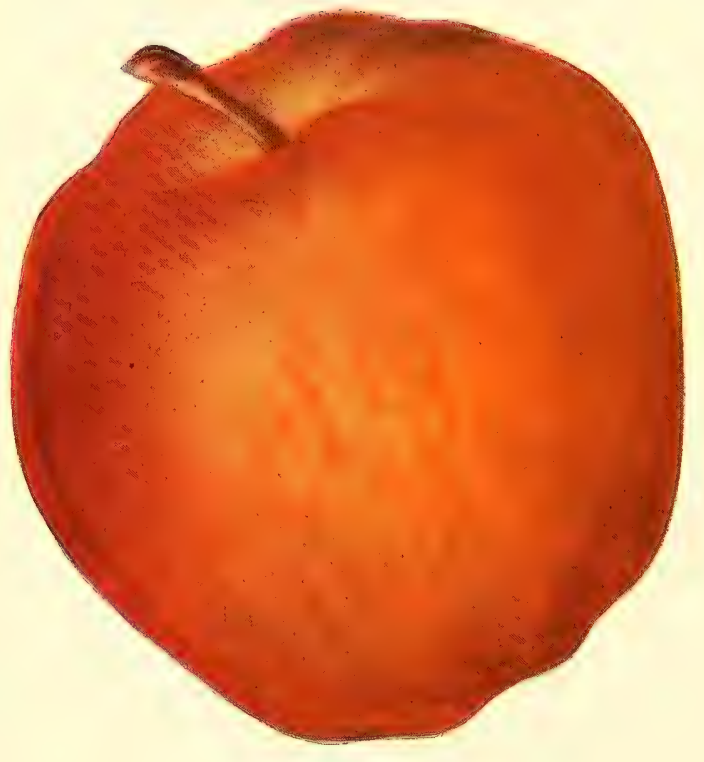

DELICIOUS APPLE 
CHAPTER XIII.

SCIENCE OF GRADING AND PACKING APPLESDIAGONAL PACK.

By Roy C. BROCK, HoOD River, OREgON.

(By permission of Better Fruit).

Grading for both quality and size is so closely related to the packing of apples that it seems almost necessary to deal shortly with it. Grading should begin with the picking of the fruit from the trees. Pickers, after having taken the fruit from the trees into pails, bags or other receptacles, should be required to empty them into the apple boxes, which are to be taken to the places for storing, not by pouring, but by hand, and then as though each fruit was an egg. During this transfer the picker should look for fruits badly blemished, and place either in boxes or in piles under the shaded side of the trees, in order that they may be gathered and so disposed of as each grower's conditions will permit. The fruit so assorted may then be stored in the place for receiving them, and left until such time as the owner is desirous of packing, at which time the fruit should be carefully assorted in readiness for the packers. Of course the appliances used will largely govern the further direct plan of procedure. However, the writer, after carefully investigating the plans used in Wenatchee, Yakima, southern Idaho and Hood River, believes the most convenient plan for handling, and the one that grings the best results as to saving of time, expense, labor and from general confusion, is the proper establishment of appliances as follows. (This refers to the handling of the average crop of from 2,000 to 20,000 boxes of apples; either greater or smaller crops may require different plans of procedure) :

In building a storing house with packing compartment thereto, the opening between the storing room and the 
packing shed should be made in the center of the side of the storing room, and not in the end of the building. By using the proper and most complete packing table all the materials needed in packing may be readily at hand and save considerable loss of the packer's time in waiting to be supplied with same. The packing tables should be equipped with proper and handy places for lining paper, layer board, wrapping paper, etc., and so arranged that the packer may have three diferent sizes before him at one time. For instance, while packer No. 1 is packing, say, 72,112 and 128, packer No. 2 may utilize the three probable other sizes that No. 1 cannot then use-80, 88 and 96 . As Packer No. 1 completes one of his numbers he has but to notice the size about completed by No. 2 , and if the contents of the tables used by No. 1 and No. 2 show a sufficient quantity of the best sized apples used by No. 2 in completing his nearly finished box, No. 1 may then commence a box of the same size, and likewise each other packer. In this way all the sizes may be kept cleaned from the tables and a packing of the different sizes distributed to each packer in proper turn. Of course the most important feature of a successful packing crew is a perfect system. A complete system cannot be brought about by proper fixtures alone. In fact some very inconvenient packing sheds have, with careful thought of the foreman, brought out a system seemingly impossible to attain.

Packing is the classification of fruits into their proper sizes by placing the fruits of the same size solidly into boxes in such a manner as to insure uniformity of appearance, neatness and protection from bruising. The purpose of careful packing is to make the box of fruit attractive as possible, and thereby receive the highest possible price for it.

There have been a number of different systems of packing in boxes followed on the Pacific coast for a number of years, and this was brought about in an endeavor to adapt the size and shape of the fruxit to the size and shape of the box used in that particular locality from which the different systems originated. After a number of 
years' experiment nearly all of the sections found it impossible to suit the size and shape of the fruit to the box, so have rearranged their ideas and are now suiting the size and shape of the box to the size and shape of the fruit, and have reduced the systems practically to one, and in such a way that every size or shape of apple grown may be neatly and solidly packed by the use of two boxes, i. e., the Northwest Standard, (101/2x111/2x 18 inside measurement, containing 2,176 cubic inches, without bulge) and the Northwest Special (10x11x20, inside measurement, containing 2,200 cubic inches, without bulge).

At this point I wish to warn the purchaser of boxes against improperly made boxes, for there is nothing so distasteful to the trade as a poorly manufactured box. Do not buy apple boxes with heads less than three-fourths inch in thickness. Do not buy boxes with sides less than three-eighths inch in thickness. Do not buy boxes with top and bottom board thicker than one-fourth inch, for these must be thin and springy. Do not buy boxes unless the top consists of two pieces and the bottom of two pieces, with two cleats each for top and bottom. Do not use sides made of two pieces, even though tongued and grooved, for they are much weaker than single-piece material of the same thickness, and when a box is tightly packed will bulge, and as apple boxes should always be handled on the sides, when so handled will undoubtedly damage the fruit. This is also the reason for insisting on full three-eighths-inch thickness in these pieces.

Returning to topic just left, both these boxes, Northwest Standard and the Northwest Special, should, when packed, have a swell in the center of the box on both top and bottom of about three-fourths of an inch on each side. The manner of bringing this about will be dealt with later in this article, and thereby adds to the cubic contents of the box.

The size of the apple is invariably determined by the diameter of the apple from cheek to cheek at the widest point, never from stem to blossom, hence the reason why an apple should never be placed stem or blossom-end toward the sides of the box. Hardly an apple is absolutely 
circular in shape at its greatest cheek circumference, and it is here that the packer may take advantage of this irregularity in packing Ben Davis apples, one of the most difficult of apples to pack, for the reason that they are about the same distance from stem to blossom as from cheek to cheek, and will not, when turned, have brought about the results usually attained by turning in this manner. However, as before stated, if the packer will carefully save for the end of the boxes those even in a slight degree irregular and place at the ends so as to keep the apples lowest where they will not prove too high, and by the use of the more nearly circular ones through the center, a beautiful crown may be brought about.

The diagonal system as used in the Northwest Standard and Northwest Special boxes is made up of the following sizes: $41,48,56,64,72,80,88,96,104,112,120$, $128,144,138,150,165,175,190,200$ and 225.

The sizes 41, 48, 56 and 64 are largely used for exhibition purposes, although a few boxes of these sizes are packed of certain large growing varieties. You will notice that most of the packs are what are known as the two-two. In packing any one of these, start by placing one apple in the lower left hand corner and the other in the center of the space left from the cheek of the apple placed in the corner to the opposite side of the box. This will leave a space on either side of the apple last placed of equal width. Settle firmly back into the spaces then left two more apples in exactly the same relative position on the other side of the box. Continue this until the opposite end of the box is reached, where there will be a space which, by a firm pressure downward and toward the packer, will enlarge the space sufficiently to permit of the last two apples being fitted snugly into place and at the same time take all of the extra slack out of the layer. Begin the second layer by placing the first two apples into the two little pockets formed by the spaces and the first four apples in the first layer, and continue to the end of the box as in the first layer, ending up with last two apples in the pockets similar to those at the begin- 


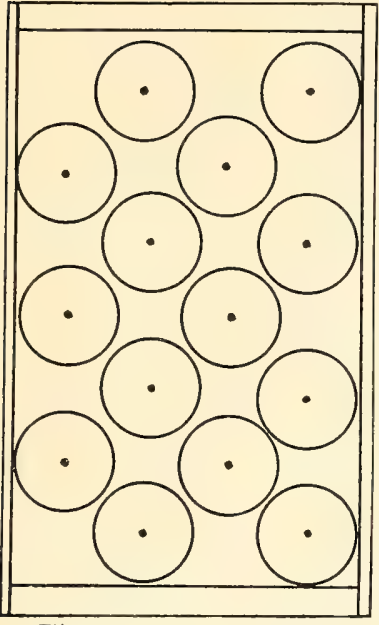

Figure $1-56$ Apples Northwest Standard Box
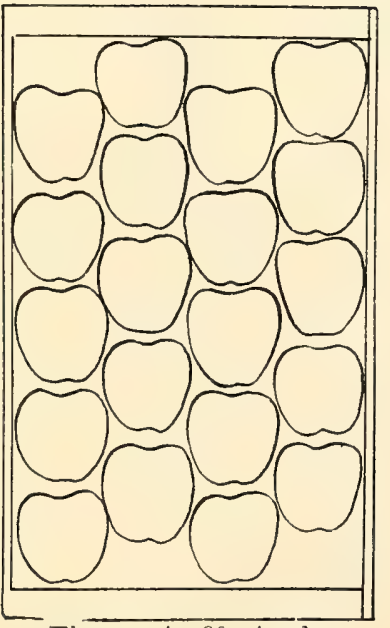

Figure 4-80 Apples Northwest Standard Box

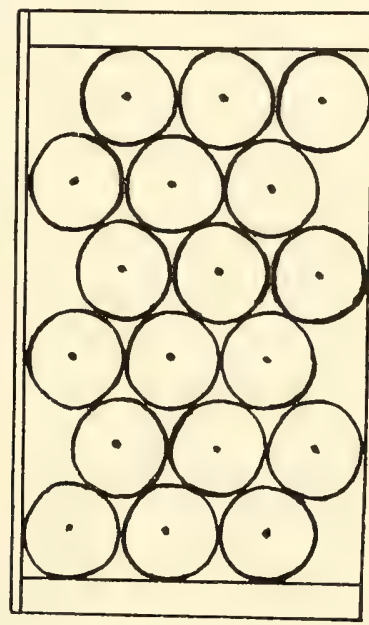

Figure 3-72 Apples Northwest Standard Box
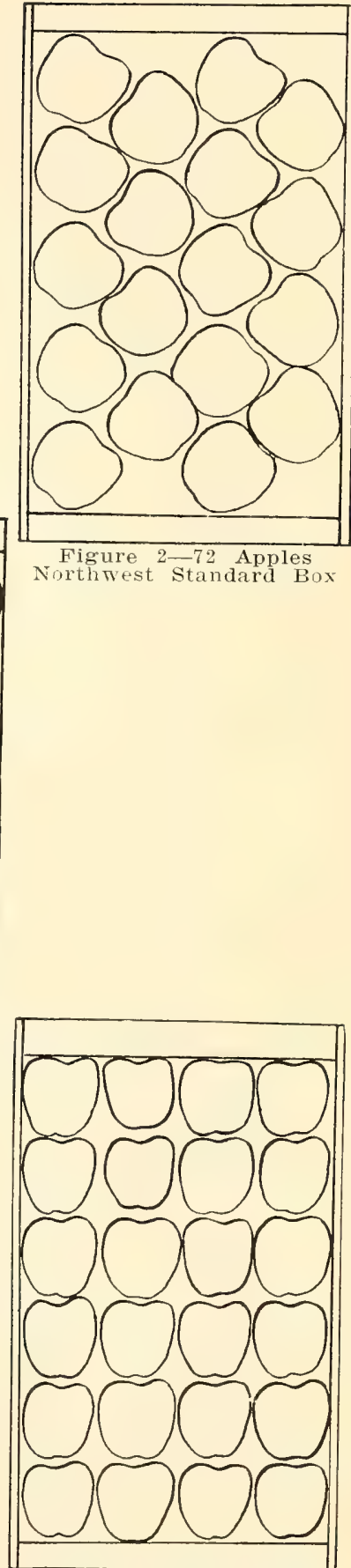

Figure 5-96 Apples Northwest Standard Box 



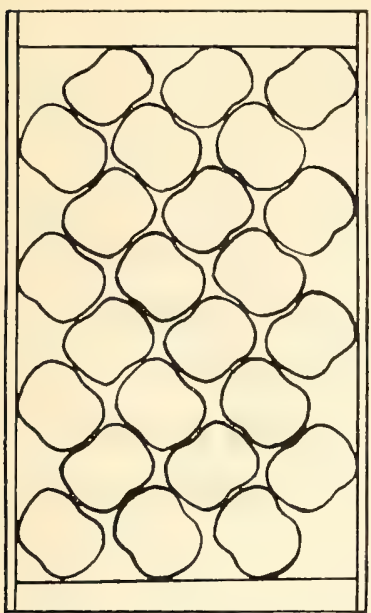

Figure 1-96 Apples Northwest Standard B ox

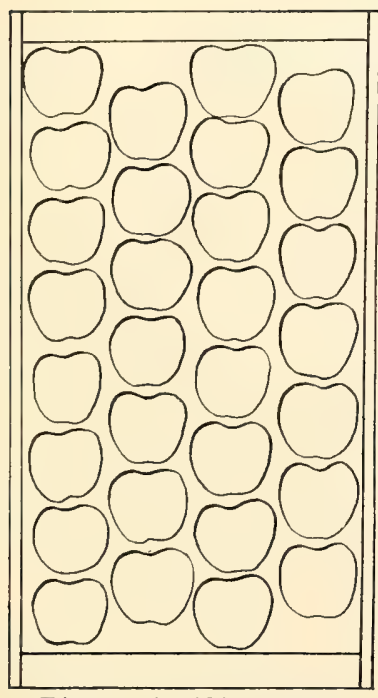

Figure $4-120$ Apples Northwest Special Box

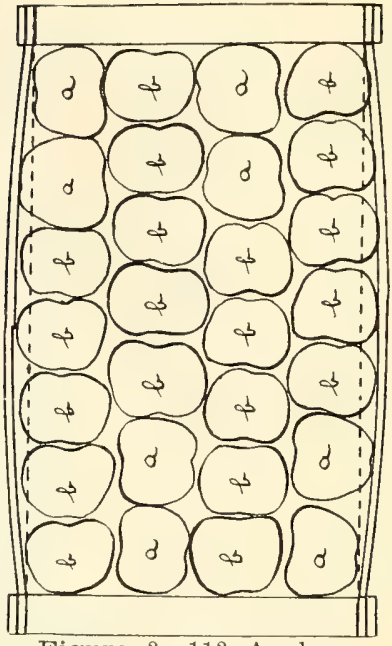

Figure 2-112 Apples Northwest Standard Box
Figure 3-112 Apples Northwest Special Box

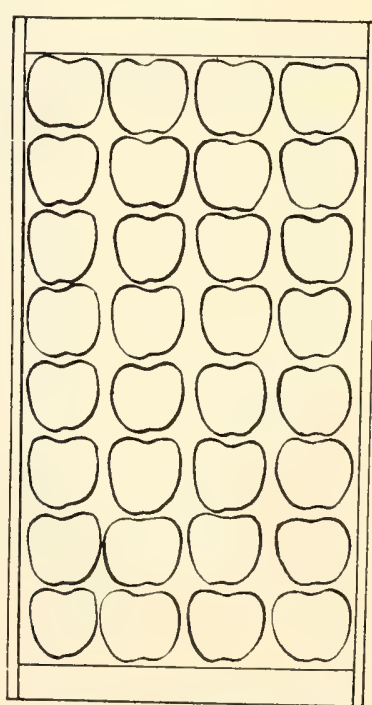

Figure 5-128 Apples Northwest Special Box 



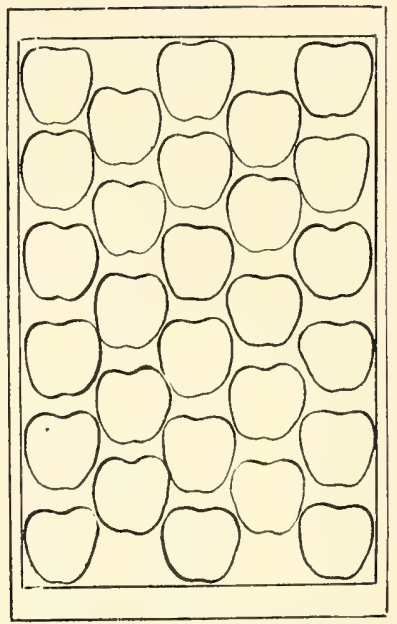

Figure 2-138 Apples Northwest Standard Box

Figure 1-128 Apples Northwest Special Box

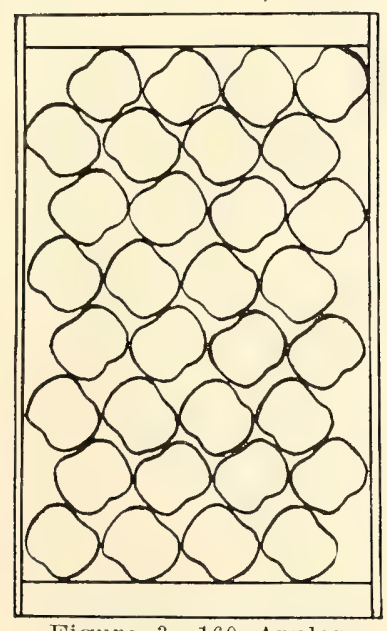

Figure 3-160 Apples Nortliwest Standard Box

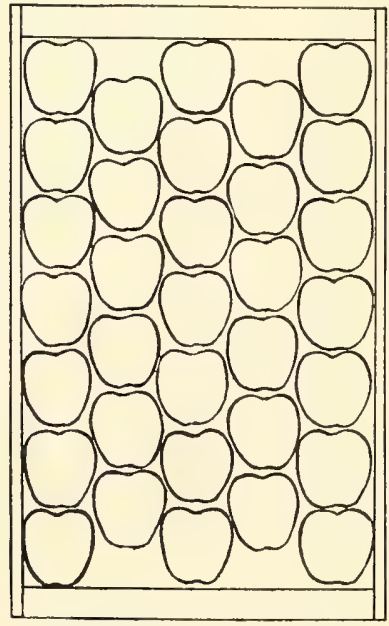

Figure 4- 165 Apples
Nortlowest Standard Box 

ning of the second layer. Continue to build up the third and fourth layers in the same way as the first and second, always placing the apple in the pockets formed and never directly over the cheek of the apple below (except, of course, where necessary in the straight four-tier pack, which is as little used as possible, as it is very likely to bruise the fruit and create a blemish).

Oftentimes, in order to keep the two-two pack from coming too high at the ends of the box on sizes ranging from 41 to 72 , inclusive, particularly on the larger of these sizes, it is necessary, because of the length of the apple, to turn all the layers of the box so that the apples are either stem or blossom toward the top or bottom. Where apples are like the Wagener, or some of the other flat varieties, it sometimes becomes necessary to turn a row or two at one end of each layer in order not only to lower the ends but to fill up in length the space yet left, alternating so that the rows turned with the stem or blossom toward the top or bottom of the box will be on layers Nos. 1 and 3, on the end of the layer farthest from the packer, and Nos. 2 and 4 on the end nearest the packer. The reason for turning in this way is that, until one layer is almost completed, it is hardly possible to know how many rows must be turned in each layer. This can be determined as the end of the first layer is reached, and in the same manner turning in each succeeding layer as above stated, first at one end and then the other. The reason for alternating the turnings of apples on each layer is that, should the nearest rows on each layer ana the farthest be turned and the rest on edge, it would make the ends too low, and the change from the turned apples to those cheeked abrupt and unsightly, besides allowing the cover to rest only against the cheeked apples, and allow an opportunity for the flat ones to become loose in the box. No definite rule can be given for turning of apples in this way other than may be determined by trial of each variety. Should more than two rows be required to be turned it would either indicate that the packer was not making the rows fit snugly across the box or that the variety was decidedly flat and should be 
packed entirely on edge. This, of course, does not apply to cases where all the apples are turned flat. Never turn an apple stem or blossom directly toward the side of the box. Often apples are partially turned in order to form pockets for the next ones, but this is not directly to the side and is permissible. Never pack apples on cheek at the end rows of the layer and flat in the middle of the layer. This will cause the ends to be high and the centers low. Ordinarily growers endeavor to find proper shapes of apples to do away with turning flat in order to make a uniform display of the cheeks. But commercially this is unnecessary, as the apples are entirely wrapped, and when inspected by prospective purchasers are usually taken from the sides of the box where all layers may be reached, and only a single apple at a time inspected and replaced. In this way no lack of uniformity of position is displayed. The straight four-tier packs, 96, 112, 128 and 144, are to be avoided as much as possible for reasons as before mentioned. However, it is almost impossible to pack a crop of any size without using these packs. When they must be used be very careful to follow the outline just given as to turning the apples flat and never allow the four apples in each row to be loose from side to side of the box. This does not mean that they should be forced in so tight as to bulge the sides, but just tight enough that there will not be a space the thickness of a sheet of paper between them. I wish to state right here that the writer has had the teaching of many beginners in packing and has found beginners to have more trouble resulting from this one thing than from all others combined. Make the apples fit snugly across the box. The next greatest fault is in keeping the size of the apples the same in each box. Mr. Packer, if you do not have the size of the apple on the table that you are packing in the box either wait for more of the proper size or start the size you have on the table in another box. You will no doubt have trouble sizing them at first, but after a couple of weeks' steady and conscientious sizing you will find you feel almost like a veteran at it and will wonder why it was ever hard.

Among other points for the beginner or the improperly 
taught to remember is never to load the packing table with several boxes of apples at the same time. The more apples and the more sizes from which to choose the apple needed adds to the difficulty of choice, and this ordinarily will hold good for the packer of long experience, for you will very often find him rolling over a heap of apples trying to find the ones wanted when he has, right on the top before him, just the one wanted. Rolling and handling in this manner is injurious to the fruit.

When the larger sizes have been packed, and it becomes necessary to pack those commonly known as the four and a half tier, the pack is started with three apples across the end of the box, one in each of the corners nearest the packer and one in the middle. Then place an apple in each of the two pockets tius formed and then three in the pockets next formed until the end of the layer is finished. This layer may end three across or two across, as the case may be, determined by the size of the apple used. However, the next layer will start with two apples placed in the pockets formed by the first five apples and space. Continue this until the box is completed. It is found on most varieties that 138 and 150 are best packed flat through the entire box, always as in the large sizes of the two-two, using those shortest for the rows next to the end of the box and the longer through the centers. The 165 and 175 usually pack with part of the rows flat toward the ends and centers on edge. These packs are all known as the three-two.

The 200 and 225 are the straight pack of five-tier, and the same general plan will apply as is used in the 112 and 128 where packed a straight four-tier pack.

You will note by the following summary in which sizes are given and the boxes in which they are to be packed, also classified in tiers, that the purchaser would, upon reading the number of apples marked upon the box, immediately know the tier, but should the tier only be marked he would in each case have four guesses coming. The tier of boxes is entirely unnecessary, except possibly where the dealer might wish to cover up the fact that a three and a half tier was a larger apple than the purchaser had desired, or where a four and a half tier may be smaller 
than supposed. This practice can only hurt the grower in the long run, and my advine is to use the number of apples in the box rather than the tier.

Northwest Standard Box-3-tier, 41, 48, 56, 64; 31/2 tier, 72, 80, 88, 96; 4-tier, 112; 41/2-tier, 138, 150, 165; 5-tier, 175, 190, 200, 225. Northwest Special Box--4-tier, 104, 112, 120, 128; 41/2-tier, 144.

Should paper for lining, layer boards and wrapping be used care should be taken to have all as neat as possible. First line your box by taking two sheets of lining paper in one hand and holding at the ends with both, then place the left hand into the box in such manner as to let the end of the paper extend over the crack in the center of the box about one and one-half inches; then carefully crease in the bottom crack at the bottom of the side; then crease down over the top of the side board. Then remove one of the sheets, and by fitting the crease made by the top of the one side board to the top of the other side board you will have a neatly creased paper with exactly the same lap on top and bottom. Then put in a layer board and commence with packing. In taking the wrapping paper use a rubber finger stole, which may be secured at any drug store, hold the palm of the hand downward and picking up the sheet of paper with the thumb and forefinger, but not turning the hand over, as seems most natural, hold in the same position as at the time of taking the paper and then place the fruit held in the other hand into the paper against the palm of the other, then the same hand to smooth the paper to fit the apple, giving a little twist to hold the apple in place. Then place the apple in the box with ine ragged ends upward for two layers and downward for the remaining layers.

\section{OFFSET SYSTEM, INCLUDING THE SQUARE PACK.}

The writer here wishes to repeat one paragraph of the foregoing article, namely, the definition of packing: "Packing is the classification of fruit in the proper sizes by placing fruit of the same size solidly into boxes in such a manner as to insure uniformity of appearance, neatness 

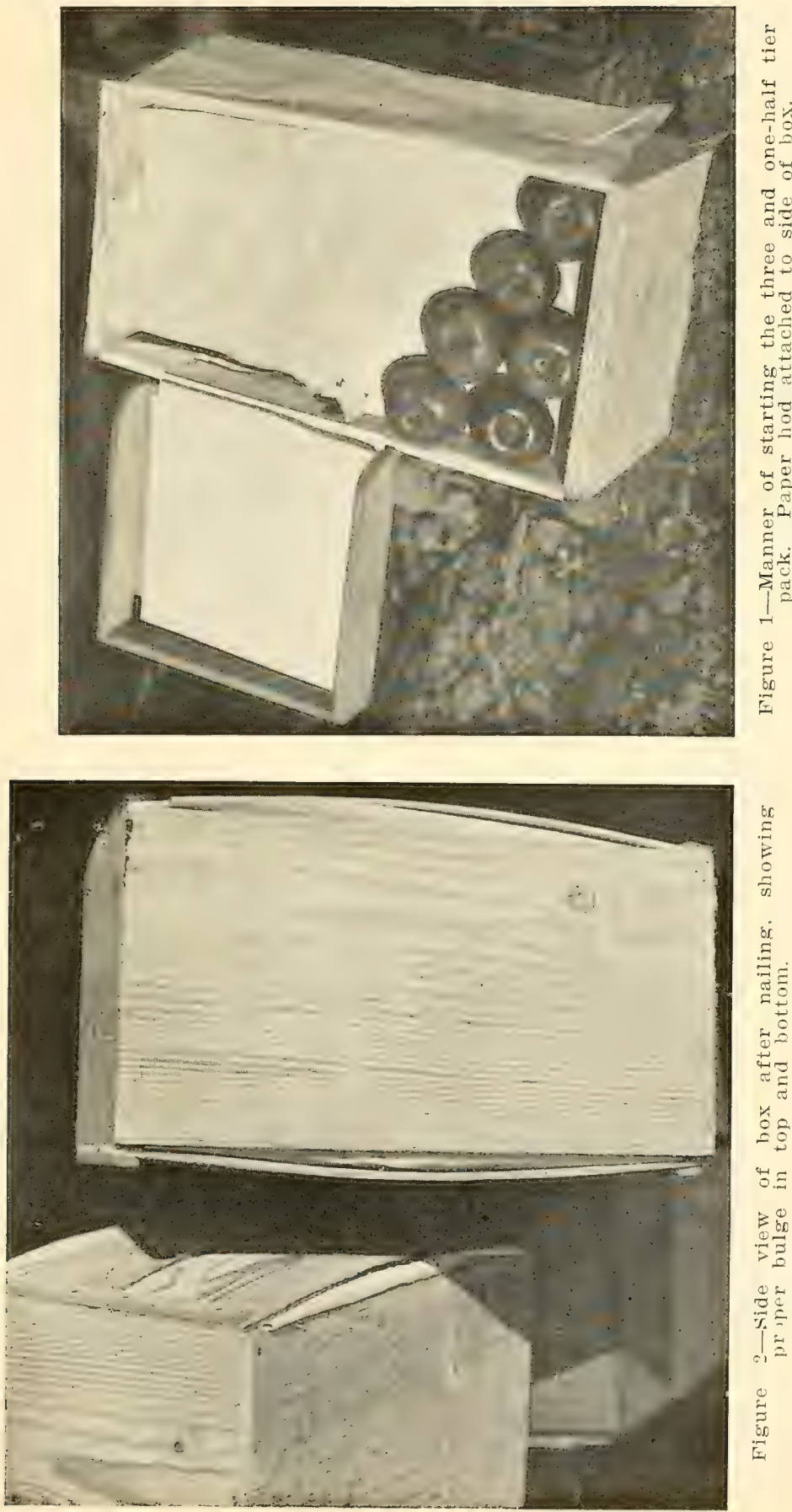

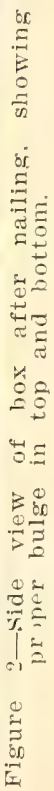




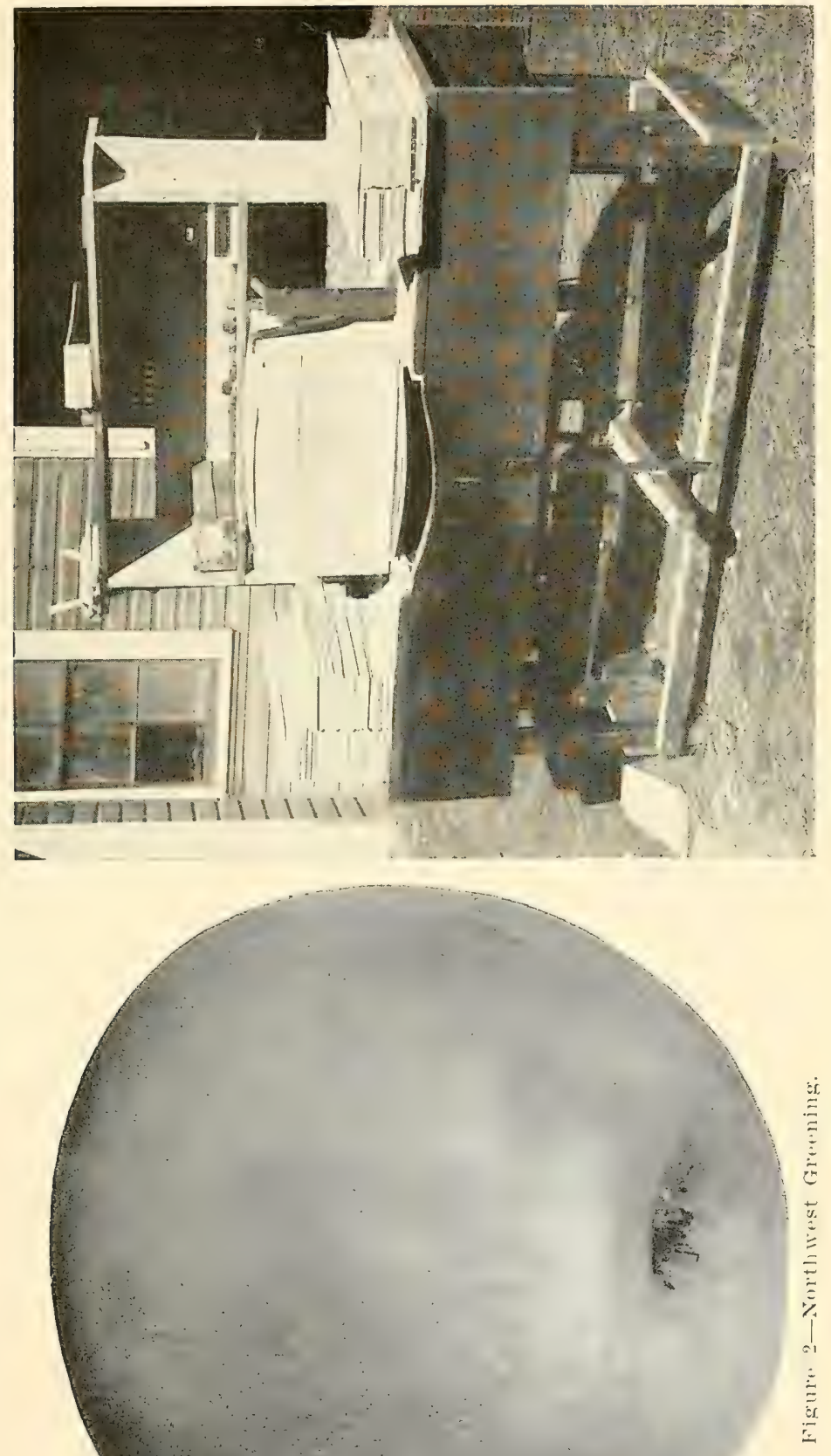



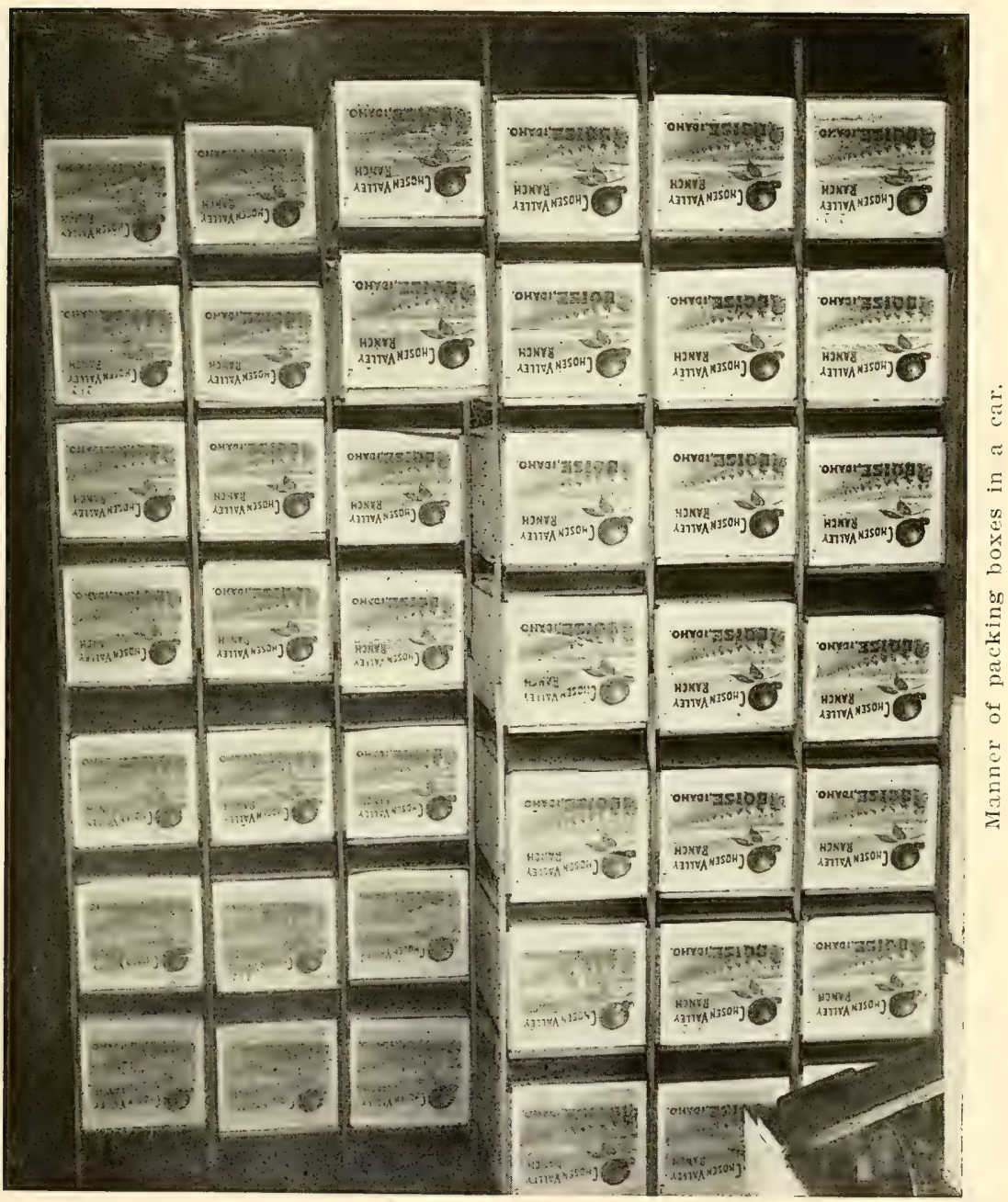



and protection from bruising. The purpose of careful packing is to make the box of fruit as attractive as possible to the purchaser and abtain thereby for it the highest possible price."

Generally speaking, the diagonal system is considered more acceptable to the trade than the offset system. However, there are several advantages to the grower who is a beginner in the business and wishes to get out the best possible pack with packers who are not experienced. With the diagonal system it is much easier to vary the size of the fruit used in each box from the bottom and center layers without materially spoiling the appearance on top. The inexperienced grower or foreman would, therefore, be led to believe from the surface appearance that the under layers had been packed as they should have been. The poor work would, however, be undoubtedly discovered on opening the box at its final destination and complaint made by the parties inspecting it. With the offset system a single apple of improper size will bring about a condition through the general pack and on the surface layer that cannot possibly be covered up. On the other hand, when both systems are properly used the diagonal is more to be desired for the reason that fewer of the apples come in sizes known as straight packs, i. e., 45, 54, 63, 112, 128, 144. In the offset packs the spaces show on the sides of the box, where they have a disagreeable effect upon the eye of the purchaser.

The offset system used in the Northwest Standard box

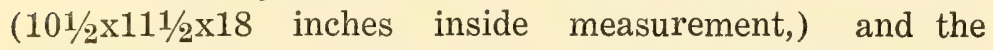
Northwest Special box $(10 \times 11 \times 20$ inches, inside measurement), is made up of the following sizes: $41,45,54,63$, $72,84,96,112,128,144,160,180,200,225$. The sizes $41,45,54$ and 63 are largely used for exhibition purposes, although a few boxes of these sizes are required to be packed for the larger growing varieties. In packing the size 41 start by placing the first two apples in the bottom corners of the end nearest the packer, placing a single apple in the crotch or pocket left between the two before placed. Now place an apple in each of the two crotches formed by the apple last placed and the sides of the box, 
and so continue until the last two apples have been firmly wedged against the end of the box away from the packer. Start the second layer by placing an apple in the pocket formed by the three first apples in the first layer at the end of the box nearest the packer and then follow with two apples, one in each of the center pockets formed by the two apples of the first layer, the one just placed in the second layer and the sides of the the box. Continue this layer, ending with a single apple at the end of the box farthest from the packer in the same relative position as that of the first apple in the second layer of the box. The last layer will begin and end with two apples at each end and will really mean an apple in each of the four upper corners of the box. The 41 size of pack will always come on edge or cheek.

Size 45 in the standard, 64 and 63 in the special are considered among the straight packs and consists of three layers deep, three apples wide and vary nine apples $\epsilon$ ach in contents. Occasionally one row of apples at end of each of the two layers in the 45 and 54 sizes require to be turned flat in order to keep the apples from being too high at the end and sufficently snug in length. Further explanation of these packs is surely unnecessary.

Sizes 72 and 84 are the sizes in this system of packing from which the name "offset" was taken. Start the first layer of these two sizes with three apples of the same size firmly together, cheek to cheek, with the stem or blossom toward the head of the box, with the first of the three in this row firmly against the left hand side of the box. Each of the other apples in the row directly against the cheek of the one next in the same row, leaving all the space in the same row between the last of these apples and the right hand side of the box; in the pocket thus formed place the first apple of the three constituting the second row, leaving the alternate space on the left hand side of the box. Continue each of the rows in the same manner, alternating the space first on the right hand side and then on the left hand side until the last row is forced into this relative position, sufficiently tight to key the whole layer. Start the second layer by placing the first apple of the first row in the pocket formed by the space in the first row of the layer. Place the next two apples of the first row of 


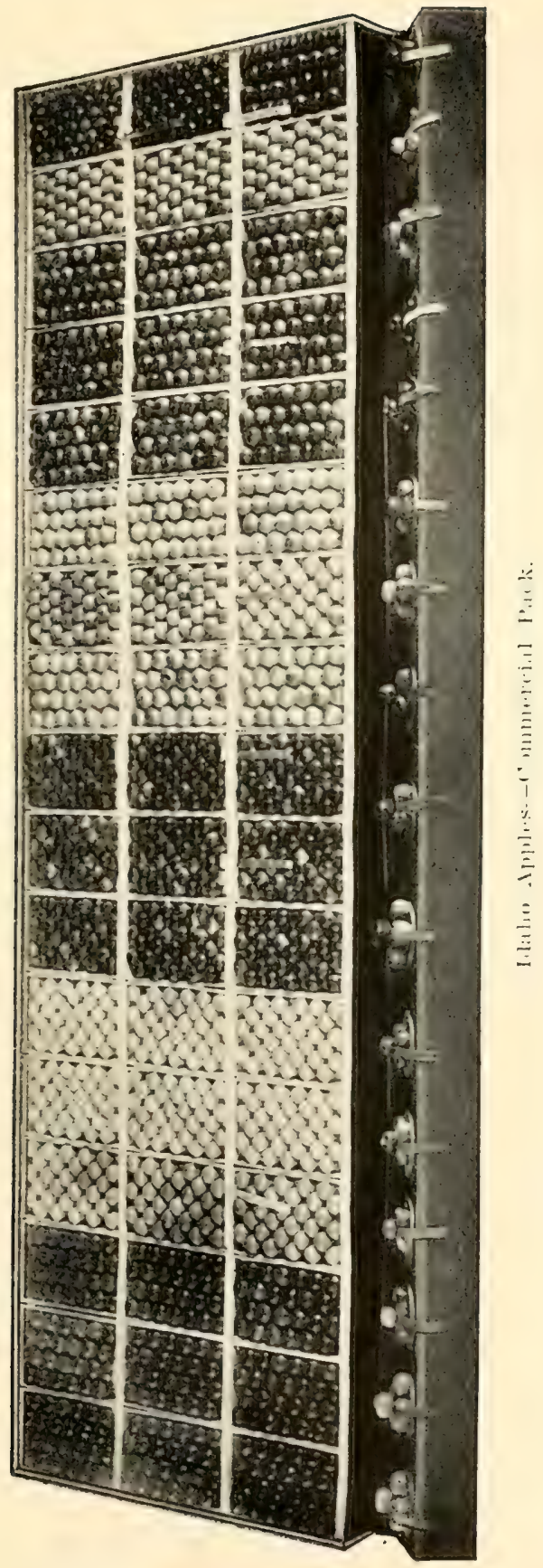



the second layer cheek to cheek against each of the others, leaving a space on the left hand side of the box, alternating each space and row from this first space and row in the second layer until the second layer is completed. Continue each of the two following layers in the same manner until the pack is finished. In no case, in an offset size, lay an apple directly over another; always place the apples so that they will come over the pockets or semi-pockets which are formed by two or three apples, and possibly one side of the box.

The 72 size nearly always packs best for length and height flat, unless the apple is very flat, when it will more than likely pack as an 84, all on edge or cheek. The 84 usually packs on edge, except with occasional one or two rows on one end of each layer, which may require to be turned to make length in the layer and proper height in the end. In turning these rows alternate, turning the last one or two rows in the first and third layers at the end farthest from the packer, and in the first one or two rows in the second and fourth layers at the end nearest to the packer. The 96 and 144 sizes, almost without exception, pack on edge or cheek, are four apples wide, fitting the box snugly with absolutely no pocket or space next to the side boards and none at the end. It is four layers deep, and occasionally, with very flat apples, the 96 size is packed as an offset pack all on cheek.

Sizes 160 and 180 are offset packs and are packed in the pretty thoroughly discussed in the writer's former article, and on referring to it a full description may be had. Sizes 160 and 180 are offset packs and are packed in the same manner as 72 and 84, except that there are four apples to each row and five layers to the box. Sizes 200 and 225 are straight packs, as 112, 128, 144, and the same general plan is followed in their packing. Sizes 200 and 225 are five apples to each row and five layers deep.

The same general rules are given in the description of the diagonal pack in the article last season and should be studied, together with the diagrams and descriptions herein given. Sizes 41, 45, 72, 84, 96, 112, 160, 180, 200 and 225 are packed in Northwest Standard boxes; sizes 54, 63, 128 and 144 are packed in Northwest special boxes. 




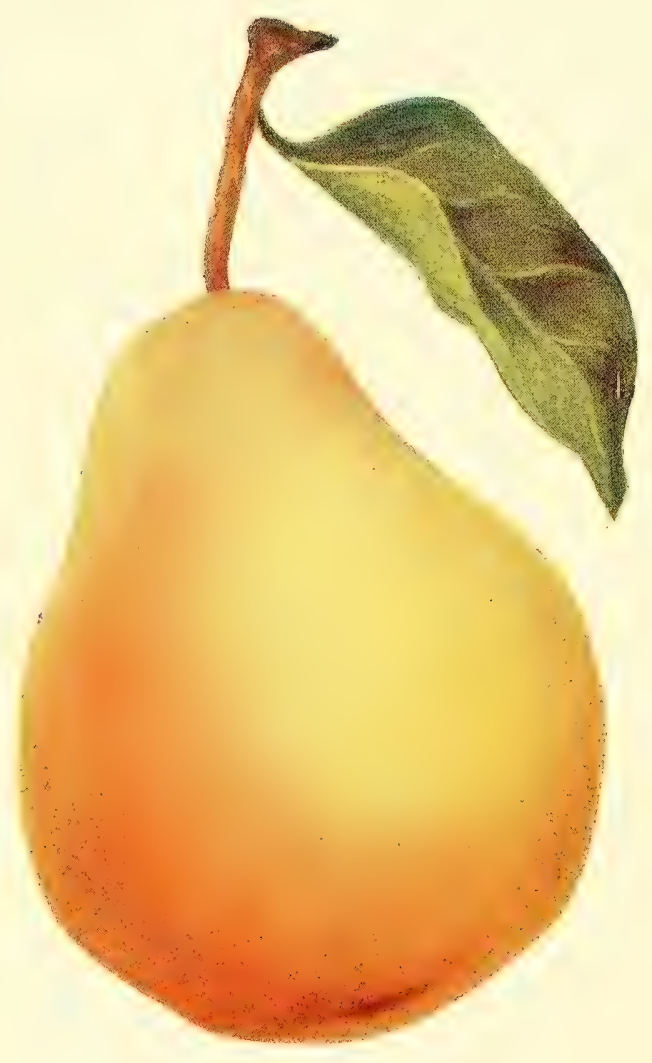

COMICE PEAR 


\title{
CHAPTER XIV.
}

\section{PRINCIPAL INSECTS INJURIOUS TO FRUITS IN IDAHO.}

\author{
COMPILED BY J. U. MCPHERSON.
}

All insects have in their natural habitat enemies which prey upon them and thereby control, to a great extent, the increase and damage done by them. When man, by changing the natural conditions, disturbs the equilibrium of nature, many kinds of insects increase rapidly and prey upon the cultivated crops and trees, thereby rendering necessary artificial means of control. As with other lines of agriculture, the horticulturist, in order to achieve success, finds that he must wage a constant warfare upon insect pests.

The insects injurious to fruits in Idaho are numerous. The fact that we have been bringing into Idaho numbers of fruit trees, vines and plants from different parts of the United States and foreign countries, well explains why we have so many injurious insect pests to contend with. For many years great quantities of nursery stock of every description were brought within our borders without inspection of any kind, without a warning hand to stay, without any measure of relief for damage already done, and in many cases without a semblance of honesty on the part of the dealer with regard to the stock being free from these most damaging and pernicious insect pests. With almost a mania for fruit and tree planting, the very ones who sought to build up and advance the cause of horticulture in our state, unfortunately brought the pests here.

The two insects which cause the greatest damage to the fruit crops of the state are the San Jose scale and codling moth. Other pests of less importance are the large family of aphides, several kinds of scale, peach and apple borer, pear and cherry slug, red spider, pear blister mite, etc. Following will be found a brief description of many of 
these pests with their life history, together with the remedies for their control.

\section{SAN JOSE SCALE.}

(Aspidiotus perniciousus).

Perhaps no other fruit insect pest has been so widely discussed as the San Jose scale, and it has undoubtedly been the cause of more legislation, both in this country and abroad, than any other insect pest known. In fact, as a result of the importation of this scale, insects have assumed international importance and occupy a prominent place in the regulation of commerce; and there is much legitimate basis for this interest and publicity.

Had it not been for the introduction of this troublesome pest it is doubtful if Idaho, up to the present time, would have had a horticultural law. Yet the San Jose scale is no longer feared in Idaho, as it has been definitely settled that spraying once a year with lime and sulphur solution, if properly done, will keep the infested plants practically free from scale.

Other results have followed the spread of the San Jose scale. In fighting this insect the orchardist has made himself familiar, not only with the San Jose scale, but has absorbed much useful information along the line of insect control and of modern methods of taking care of the orchard.

The injury done by the San Jose scale is the absorption of the juices of the tree or plant, the scale insect in its relation to its food plant being a mere pumping machine which is continually extracting the sap from its host. For this purpose it inserts its long, slender beak or proboscis deeply into whatever portion of the plant it may be resting upon-bark, leaf or fruit. While the amount of sap extracted by a single insect is very. small, when multiplied by millions it greatly depletes the juices of the plant, and will, in a few years at most, cause the ultimate death of the tree or plant.

The insect winters in the larval state, usually about half grown, both sexes being found. Probably in the fore part 


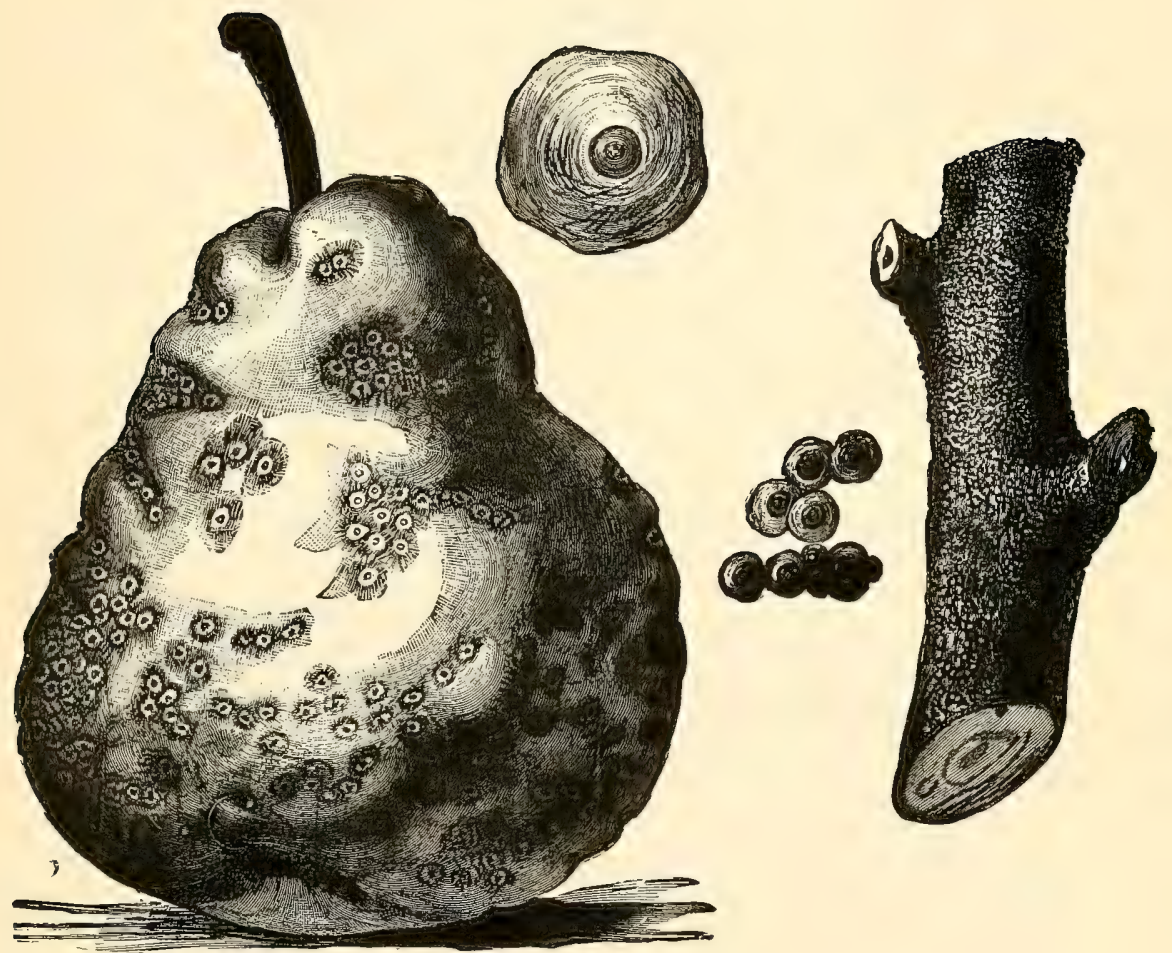

San Jose Scale- (Aspidiotus perniciosus). Infected fruit and branch and enlarged scales [Howard]. From Bulletin No. 34, New Series, by Nathan Banks, U. S. Department of Agriculture, Division of Entomology. 

of June (depending upon weather conditions) the females become fully developed, and instead of producing eggs, begin to bring forth living young. That is to say the species is vivaparous. While very minute, the young are not yet visible to the naked eye, and, by sharp inspection, during the breeding season may be seen running about on the leaves, twigs and fruit. In color they are usually bright lemon-yellow. They have six well developed legs, also antennæ and eyes, and are highly organized in comparison to the degraded condition soon to be assumed. After finding a suitable situation (often within a few minutes of the time of their emergence from beneath the old scale, though sometimes not for a day or two) they settle down, thrust their long, slender, hair-like beaks into the plant, and immediately begin growth. The first evidence of this growth is the secretion of waxy filaments from the upper surface of the body, which mat down and form the beginning of the scale covering. The waxy secretion continues during the life of the insect, and the scale is thus enlarged as the insect increases in size. The male, after molting, becomes winged, and though very frail in form, has the power to fly from tree to tree, and with a favorable wind may be carried a considerable distance. The females undergo two molts, and the skins thrown off in these molts attach to the scale and form a definite part of it, being cemented closely to it with the wax. The female insect, after the second molt, soon reaches full size, and when fertilized by the male begins to develop her numerous progeny of young. The female insect, having once thrust her beak into the tissues of the plant as a larva and begun the secretion of a covering scale, never moves from her position, and, in fact, if she be removed by force is never able to penetrate the bark again with her sucking beak, and thus soon perishes. The opportunity for the local spread, therefore, of these insects is limited absolutely to the first larval stage, differing in this respect from most sucking insects, which have the power to move and change their position until nearly the end of their growing period. The number of young produced varies with the season, a less number being gen- 
erated in unfavorable than in favorable seasons of the year. The progeny from a single parent insect in a year, on the supposition that they should all survive, would represent almost inconceivable numbers, running into billions. It is not to be wondered at, therefore, that the plants become thoroughly infested in a very short time.

\section{REMEDY FOR THE SAN JOSE SCALE.}

The waxy covering of the San Jose scale makes it necessary to use washes strong enough to penetrate the scale and destroy the protected insect beneath.

The proper time to spray for the scale is in the dormant season, using the lime and sulphur solution (Formula No. 1). If the trees to be sprayed have a very rough bark, this should be scraped off in the same manner as indicated under the heading "Codling Moth." After many years of experimenting in nearly every state in the Union, the spray commonly known as the lime and sulphur spray is conceded by all to be the best, although there seems to be some difference of opinion as to the amount of each ingredient necessary to get the best results, and also as to the exact time and manner of preparing the spray. But the workers in Idaho have practically agreed that the somewhat modified formula used according to the directions as given in this bulletin, will do the work in a satisfactory manner.

The last few years have brought into the market ready made solutions of lime and sulphur, sold under different brands, as Rex, Niagara, etc. These mixtures have proved very popular, and have practically superseded the use of home-cooked mixtures. The preparation of such sprays under usual orchard conditions was an arduous, disagreeable task, and the prepared mixtures have been welcomed, in spite of the slight excess of cost. The only objection to the use of these prepared mixtures has been the tendency on the part of the manufacturers to recommend them in too weak a solution. It has been found by many experiments conducted over a period of many years that it requires a strength of 3 per cent of sulphur to kill 
the scale under all conditions, and the commercial mixture should not be reduced in proportions which will reduce its strength below this point.

OYSTER SHELL BARK SCALE.

(Mytilaspis pomorum).

The oyster shell bark scale is a rather long insect, tapering toward the head and resembles very much some forms of oyster shells-hence the name. The oyster shell bark scale is a less dangerous insect pest than the San Jose scale. It does not multiply so rapidly, there being but one brood each year. They are not born alive as is the San Jose scale, but develop through the egg state. The mother scale lays perhaps fifty or sixty eggs late in the fall under the scale that has protected her during her life, and these eggs begin hatching, usually during the fore part of June, although weather conditions govern somewhat the time of hatching. The young immediately insert their beaks and begin extracting the sap of the tree.

REMEDY FOR THE OYSTER SHELL SCALE.

While this pest is not nearly so dangerous as the San Jose scale, yet it is harder to destroy on account of its breeding habits. Lime and sulphur solution (Remedy No. 1) applied as late as possible-just as the buds begin to open-may kill a portion of the scale; but whale oil and kerosene (Remedy No. 6), or whale oil and quassia chips (No. 8) applied frequently while the young are emerging, has proved the most effective.

THE CURTIS SCALE. (Aspidiotus ostreaeformis)

This scale somewhat resembles the San Jose scale and is viviparous, or produces young alive. It is somewhat rougher than the San Jose scale and the nipple-like center is surrounded by a whitish ring. This insect is usually taken for the San Jose scale and only by close examination 
can they be told apart. It does not seem to multiply so rapidly as the San Jose scale and is much more susceptible to the attacks of native enemies.

This scale is found in only a few localities in the state.

REMEDY FOR CURTIS SCALE.

Apply lime and sulphur solution (Remedy No. 1) in the dormant season. For summer spraying use whale oil and kerosene (No. 6) or whale oil and quassia chips (No. 8).

THE PUTNAM SCALE.

(Aspidiotus ancylus).

This is a native scale and is found most frequently on cottonwood. It sometimes attacks fruit trees but seems to be held in check by its natural enemies and does but little harm.

\section{REMEDY FOR PUTNAM SCALE.}

Use lime and sulphur solution (Remedy No. 1) in the dormant season.

\section{ROSE AND BERRY SCALE.}

(Diaspis Rosae).

This scale is larger than most other scales, and is almost entirely white, which makes it quite conspicuous and very easy to find. It is confined mostly to roses, blackberry and currant bushes, and shrubbery.

REMEDY FOR THE ROSE AND BERRY SCALE.

Use lime and sulphur solution (Remedy No. 1) in the dormant season.

THE CODLING MOTH.

(Carpocaspa pomonella L.)

The codling moth, or apple worm, is a familiar pest to every grower or consumer of apples; and a wormy apple, the result of its work, scarcely needs description. The 
larva, living most of its life within the fruit, throws out through its entrance hole, which it enlarges from time to time, or through its exit hole in the side of the fruit, the characteristic mass of frass or excrement which is the sign of infestation. Such an apple is practically unsalable. At best it brings a very small price, either for consumption as fresh fruit, or for the manufacture of by-products. The monetary loss thus occasioned by this insect is greater than that due to any other insect pest affecting fruits. It has been shown by careful estimates in various apple growing states that this insect, when unmolested, may cause a loss of from 20 to 100 per cent of the fruit which would otherwise be sound and merchantable. This loss estimated on the lowest or 20 per cent basis would amount annually to many million dollars in the United States, and this does not include the expenditures for spraying trees with arsenicals amounting to millions more. Great as this loss still is, it has been very much limited by measures of control which are becoming more and more widely adopted, and many apple growers in badly infested regions are now saving every year more than 85 per cent of fruit which would, without treatment, be wormy.

\section{DISTRIBUTION.}

The original home of the codling moth was probably southeastern Europe, the home of the apple, but it has followed closely upon the distribution of the apple until it is now found in almost every country in the world. It is spread principally by the shipping of the infested fruit. The young larvæ in such fruit complete their development, and leaving the fruit, spin cocoons in nearby places. The moths emerge in due course and fly to the nearest tree to deposit their eggs. When orchards are but little distances apart the moths fly from one orchard into another.

\section{FRUITS INFESTED.}

The apple is the natural food of this insect, and sustains almost all the loss occasioned by it. Pears are next in 
order of infestation, but if apples are present in the same orchard pears are usually not badly infested. The codling moth larvæ have been found also in the fruit of the quince, prune, plum, peach and cherry, but never in sufficient numbers to cause any great injury.

\section{LIFE HISTORY.}

The apple grower cannot be too strongly impressed with the necessity of familiarizing himself with the life history of the codling moth, so that he will understand the principles of its control which are based on certain vulnerable points in its life cycle. It is undoubtedly the worst of our fruit pests, causing annually an immense amount of loss, although many of our commercial orchardists are alive to the situation and are doing excellent work, keeping up to $99 \%$ of their crop of apples free from worms.

Hibernation. - The codling moth passes the winter in the larval stage in silken cocoons, hiding in cracks and holes in the trees, and in houses where apples have been stored. In the spring these larvæ change to pupæ, and the moths emerge about a month after the apple tree is in blossom.

The Moth.- The full-fledged codling moth is but little known among fruit growers, and other moths are often mistaken for it. It varies somewhat in size, but the maximum spread of its wings is about three-fourths of an inch. The front wings are of a brownish-gray color and are crossed with lines of gray scales, giving them the appearance of watered silk. At the tips of the wings there is a large brown spot, in which are many scales of bronze or gold. The hind wings are grayish-brown in color. Taken as a whole, the coloring of the moth is such that when resting on old grayish bark it is so like the bark that it is not easily distinguished. The moth lays her eggs a few days after emergence from the cocoon, on the leaves of apple or other food plants, or on the fruit. The eggs of the first generation are usually laid on the leaves surrounding the apple cluster, while the greater part of those of the second generation are laid upon the fruit. 

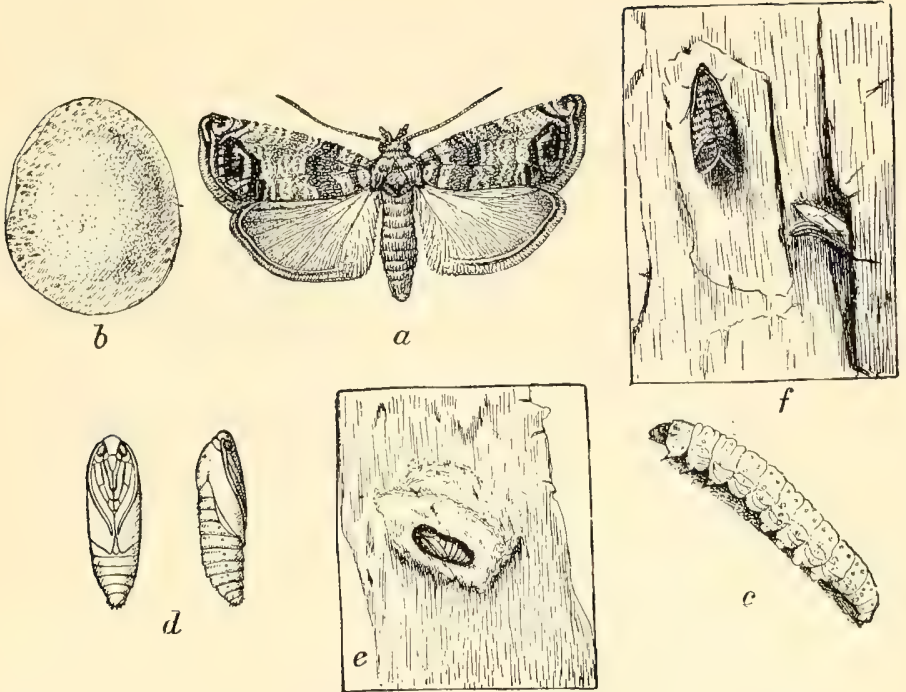

Figure 1-The Codling Moth: (a), the moth or adult insect, slightly enlarged: (b), the egg greatly enlarged; (c), the full-grown larvae slightly enlarged: (d) the pupa, slightly enlarged; (e) the pupa in its cocoon on the inner surface of a piece of bark, reduced about onehalf; (f), moth on bark and empty pupa skin from which it emerged, about natural size. (original).

Codling Moth. - From Farmers' Bulletin No, 171, by permission U.S. Department of Agriculture, Division of Entomology, by C. B. Simpson.

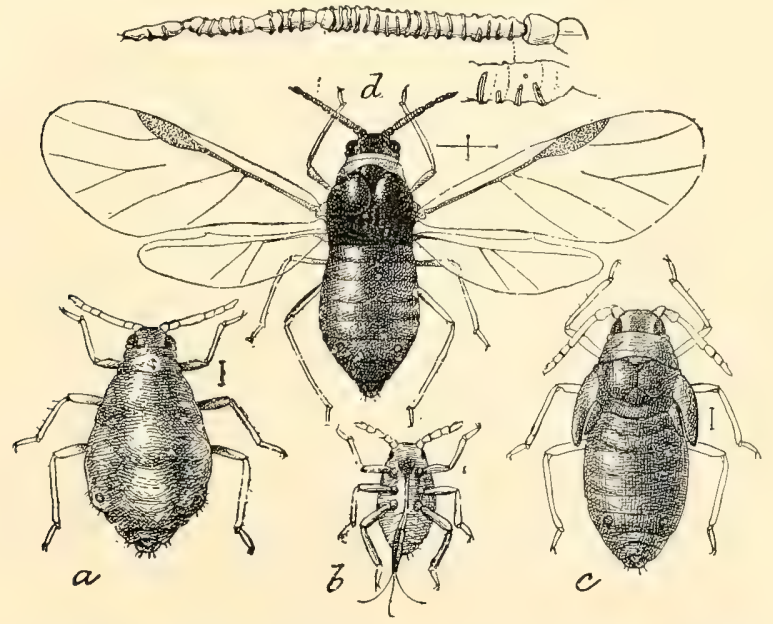

Fig. 2.--Woolly Aphis (Schizoneura lanigera. (a) agamic female; (b) larva; (c) pupa; (d) winged female. [Marlatt]. From Bulletin No. 34, New Series by Banks, U. S. Department of Agriculture, Division of Entomology. 

The Egg.- The eggs are very minute, scarcely visible to the naked eye. They are pearly white in color, resembling thin convex disks. Around the edge there is a coarse network of ridges, while toward the center these ridges are finer. A red ring which indicates the embryo or developing larva, appears in the egg a few days after it is laid and may be easily seen with a good magnifying glass.

Through the following methods our most successful orchardists have succeeded in the fight against the codling moth in keeping each year from 75 to 99 per cent of their fruit free from the marks of the worm.

In fighting the codling moth it is advisable to destroy all larvæ before they have time to become moths. The store rooms or other places where apples have been kept should be gone over and all the larvæ destroyed; rubbish and trash should be removed from the orchard and burned; all boxes and other places where the worm might hide should be thoroughly examined and the worms killed. In February or March shovel away the earth around the tree to a depth of three or four inches; (this is necessary as many of the worms find refuge in the bark and cracks just under the surface of the ground). Then take a heavy piece of muslin or canvas and hem one side over a strong cord; tie this tightly around the tree close to the ground; scrape off all rough bark, clean out all cracks where the worms might be in hiding, clean out all holes, smooth all cuts and broken places, fill all sharp angles or holes with cement or plaster of Paris; gather up this refuse and burn it. In this way, if the work is thoroughly done, the most of the worms will be destroyed.

\section{BANDING.}

Banding the trees is one of the essentials for the control of the moth, as well as giving aid in determining the proper time to spray. About four weeks after the blossoms fall put on the bands. The band should be of somewhat fuzzy texture, double, and wide as convenient, (about four inches will do). It should be long enough to 
pass around the tree and lap over two or three inches. Drive a box nail into the tree, letting it stick out about one inch; cut the head off the nail with a pair of clippers; fasten one end of the band on the nail; pass it around quite closely and fasten the other end. After the worms begin to appear under the bands they should be examined and the worms killed every ten days until the fruit is packed. After this allow the bands to remain until all the straggling worms have gone under the bands, which is usually some time in December. If the trees are very large and have limbs near the ground, it is well to band each limb as well as the trunk.

\section{SPRAYING.}

Given an efficient spraying material, the question of how to spray and when to spray becomes all important. For years it was thought best to hold the nozzle toward the tree and with a force of about 80 pounds pressure, allow a fog to settle upon the tree, stopping the spraying as soon as the tree began to drip. Among the more progressive this method has been abandoned for the use of a driving spray thrown under a pressure of 175 to 200 pounds, spraying (for the first spray at least) from above, from below and from the side, straight into the calyx cup, thoroughly wetting the tree from top to bottom.

Experiments and close observations show that the bulk of eggs of the first brood of codling moth and many of the eggs of the second brood are laid upon the whorl of leaves which surrounds each cluster of fruit. When the worm hatches, it immediately seeks the fruit, generally feeding upon the leaf before it reaches the fruit. The first brood of worms as a rule enters the calyx after the calyx has closed. In order that the poison may be in the calyx ready for the worm when it appears it is necessary to spray while the calyx is still open. The calyx commences to close immediately after the petals drop, and if the weather is warm, closes very quickly, the time varying, according to weather conditions, from five to ten days. It can thus be seen that with large orchards very, 
quick work must be done with this first spraying, and it well behooves the grower to have pumps in order and material on hand, in order that no time may be lost.

To determine the date of second spraying a few larvæ should be caged and the date of change to moth noted, and spray applied about ten days after the change from pupæ to moth, at which time the first worms would hatch.

For third spray the bands should be watched and spraying done twenty-five days after the first worm appears under the band, to be followed two weeks later with the fourth spray.

In the last bulletin issued by this department the use of tried and well known methods was recommended. Reference was made to the popular thought that one spray would be sufficient, but our recommendations were to spray at least three times, and in badly infested orchards to use what may be called supplementary methods. As the years have gone by the advocates of the one spray system have grown less in number until now it is generally accepted that from two to four sprays are wisest. To those who wish to try the one spray only, we will repeat what we said in the former bulletin referred to above. The grower should spray thoroughly at the proper time, which is when the calyx cups are still open; then band enough trees to make a practical test, taking off bands every ten days and keeping careful count of the number of worms found. If the trees average one first brood worm under the band of the tree, do not neglect the third and fourth sprays. If less than an average of one appears the grower might be justified in abandoning the later sprays.

For the experienced orchardist in an orchard not badly infested the previous season, the use of spray alone would be sufficient, but to the inexperienced grower, or where the orchard was very badly infested the preceding season, we still unqualifiedly recommend the use of bands and the cleaning of the trees. There is an additional precaution which should be used by all whenever thinning of the fruit is done, that is, while thinning, to destroy the worminfested fruit. 
REMEDY.

Use arsenate of lead (Remedy No. 4), Paris green, (Remedy No. 2), or white arsenic (Remedy No. 3), as recommended above.

THE PEACH TWIG BORER.

(Anarsia Lineatella Zell)

The peach twig borer is apparently an Old World species and probably a very ancient enemy of the peach, doubtless coming with this fruit from western Asia. It was described in Europe in 1839, and in this country in 1860. The American species was afterward shown to be identical with the European peach moth. It has been very injurious at times to peach trees in the peach growing sections of the east; on the Pacific slope its injuries have taken a wider range, including damage to the apricot, almond, nectarine, prune and perhaps other fruit trees, in addition to the peach.

The injury occasioned by this insect is limited principally to the work of the hibernating larvæ during the latter part of April and first of May, when they bore into the shoots of new leaves, killing the growing terminals and preventing the development of the branch, although sometimes a whorl of living leaves may remain at the base. Much of the new growth of the tree is often killed, in many instances the branches remaining with scarcely a bud or shoot which has not been thus destroyed. This necessarily results in greatly checking the vigor and fruiting capacity of the tree, and causes an irregular and knotty growth.

The summer broods of larvæ feed beneath the bark or in the fruit stems, and occasionally, when nearly full grown, bore into the fruit; but such damage is not ordinarily noticed and is slight as compared with the injury occasioned by the first hibernating brood larvæ.

\section{LIFE HISTORY AND HABITS.}

The fall brood of larvæ may be taken as a convenient starting point in the life history of the peach twig-borer. 


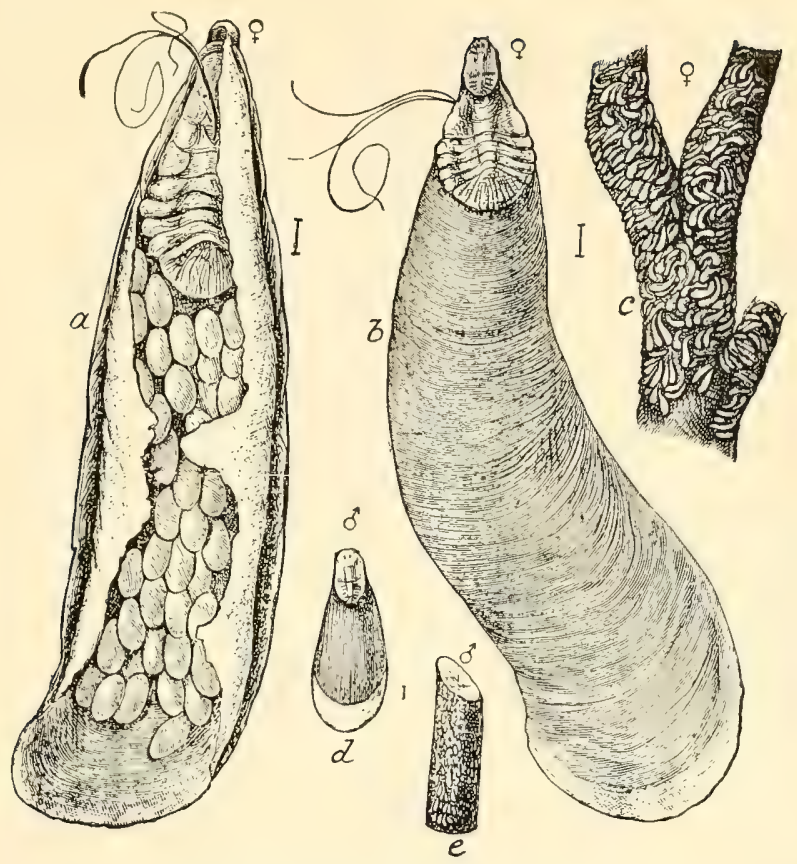

Fig. 1.-Mytilaspis pomorum. (a, b) females; (c) scale on twig; (d), male scale [Howard].

Bulletin No. 34, New Series, by Banks, U. S. Department of Agriculture, Division of Entomology.

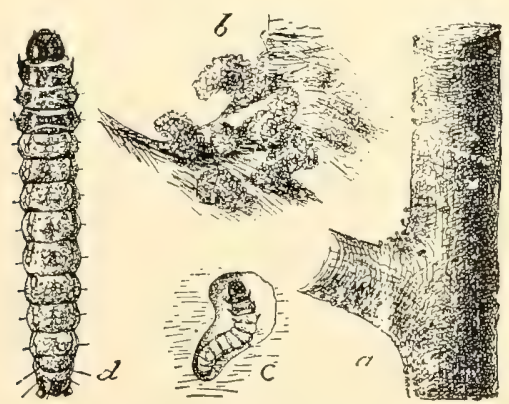

Fig. 2.- Anarisa lineatella: (a), twig of peacl, showing in crotch minute masses of chewed bark above larva chambers; (b), latter much enlarged: (c), a larval cell, with contained larva; (d), dorsal view of young larva more enlarged (original).

Peach Twig Borer-From Farmers Bulletin No. 80, U. S. Department of Agriculture, Division of Entomology. 

In the fall they appear as a very small larvæ, living and working in the spongy bark, chiefly at the crotches of the branches of the peach, and it is surmised that they are developed from eggs deposited in these situations.

While in their winter quarters the larvæ are subject to the attacks of predaceous mites, and many of them are destroyed by this means. They are also occasionally parasited by a chalcidid fly.

Early in April the larvæ begin to abandon their hibernating quarters and attack the new leaf shoots, but some individuals have been found in the crotches as late as April 21. The damage becomes noticable, as a rule, at the time the shoots are from one-half inch to two inches in length, or, more properly speaking, mere clusters of newly expanded leaves.

It is our observation that the larvæ begin to migrate only after the new foliage has begun to show. They attack the new shoots at any point, generally, however, from one-half inch to an inch from the apex, either near or in the crotch formed by the leaf petiole and the stem.

When working in the succulent new growth the larvæ bores rather rapidly, sufficiently so at least to excavate a burrow two-thirds of its length in an hour. The length of time spent by the hibernating larvæ in coming to full growth in the green shoots is comparatively short, not exceeding ten to fifteen days.

The larva on reaching full growth spins a scanty web, (in no sense a close cocoon) in the leaves and rubbish about the trees, or in the trees themselves, in the dried and shriveled leaves of the injured shoots, or it attaches itself exposed on the twigs or bark. After thus securing itself the larva immediately pupates, becoming a brown, rather robust chrysalis. In midsummer these transformations are very quickly accomplished. A larva which webbed up June 29, pupated July 1, and the adult emerged July 8.

It is very difficult to find the pupæ in orchards, as the larvæ hide in all sorts of places. They conceal themselves in the crotches of the branches, between dried leaves, and about small peaches likely to drop off. 
The chrysalis stage lasts from seven to ten days, and the moths of the first brood begin to appear early in May and continue to emerge throughout this month and into June.

The adult moth is less than half an inch in length, expanding a little more than half an inch, and is of a beautiful dark gray color, with darker spots on the forewings.

The newly deposited eggs are white in color and iridescent, but before hatching become distinctly orange. They measure about four-tenths of a millimeter in length by two-tenths of a millimeter in breadth, are somewhat ovoid, and are lightly attached lengthwise to the twig by a glue-like material.

The newly hatched larvæ measure about one millimeter in length and are of a very pale yellow color, with the head and vervical and anal plates black and the thoracic legs dusky.

At the time of the appearance of the first brood of moths during the month of May, the fruit of the peach is of considerable size, especially by the end of the month, but is green, hard and densely hairy, and is probably rarely if ever chosen by the parent moths as a nidus for eggs.

\section{REMEDIES FOR PEACH TWIG BORER.}

It has been observed that where the lime and sulphur solution has been used for scale it has very materially reduced this pest. All other recommended methods of control, such as spraying with arsenicals and cutting the infested twigs, have been found inadequate. The lime and sulphur spray applied in the dormant season will not entirely eradicate the borer, but will reduce its numbers to the minimum, and this method is unqualifiedly recommended as the only practical remedy.

PEACH TREE BORER.

(Sannina exitiosa).

The peach tree borer is quite destructive at times on 
young or newly set trees. The eggs are deposited on the tree near the surface of the ground and when hatched the young borer enters and burrows under the bark, winding here and there, sometimes entirely girdling the tree and thereby causing its death. They may also occur on other pit or stone fruit trees. As the insect increases size it eats the sap wood or tender portion of the tree beneath the bark, causing a copious exudation of gum around the base of the tree, which is easily seen. It sometimes attacks the tree higher up in a crotch or where there may chance to be a scar of any kind, but is always easily found by the exudation of the gum from its borings.

\section{REMEDY FOR THE PEACH TREE BORER.}

As a preventive young trees should be wrapped with heavy strong paper, letting the paper extend from two to three inches under the surface of the ground up to the first limbs. The top of the paper should be tied tight enough to keep the mother beetle from entering. Keeping the trees thoroughly coated during the summer with a very strong mixture of lime and bluestone is also very good. Frequent applications of the mixture should be made. After the borer has once entered the tree the only remedy is to cut it out. If this is done soon after it enters the tree may be saved.

THE FLAT-HEADED BORER.

(Chrysobothris femorata).

The flat-headed borer is by far the most common of the borer type of insect. The mother beetle lays the eggs, if on a small or newly set tree, at or near the surface of the ground; but if on an older tree, usually where a scar of some kind occurs. This scar may be well up in the larger branches.

The larva when young is of a whitish green color, but becomes almost a clear white as it advances in size and age. It eats its way into the bark and sap of the tree, making irregular channels or chambers under the bark, often girdling the young tree and causing sure death. Where 
the insect is at work beneath it the bark turns quite dark, and the castings from the worm may be seen at openings in the dead bark, thus plainly indicating its workings. This pest is sometimes very bad among the newly-set apple orchards, causing an immense amount of damage. It is much worse some seasons than others. It bores deep into the heart of young trees, and takes from one to three years, according to the rapidity with which it develops, to complete the cycle of life.

REMEDY FOR THE FLAT-HEADED BORER.

The flat-headed borer is very hard to combat, no remedy being entirely effective in controling this pest, although any of the following will sometimes relieve the situation somewhat and a combination of the lime, sulphur and blue vitriol wash and protectors will reduce the damage to a minimum.

The lime, sulphur and blue vitriol wash is made of equal parts of lime, sulphur and blue vitriol thoroughly cooked and used at the consistency of a good whitewash. Before painting trees with this mixture the dirt at the base of the trees should be removed, exposing two or three inches below the surface of the ground, then paint the bottom up to the first limbs. This work should be done early in May, as the eggs are laid by the mother beetle in the latter part of May and the larvæ hatched in June, the time varying according to wenther conditions. The object of this wash is to keep the mother beetle away from the tree through its offensive odor. The use of one of the various forms of tree protector is also an assistance. For this purpose paper is sometimes used, although the usual protector is some sort of wood veneer. The yucca palm is probably the best, as it is very porous and allows some circulation of air, which prevents the scalding of the tree. The use of tarred paper should be avoided, as it is very heating and often causes destruction of young trees. In case of a combined use of the wash and a protector, the tree should not be painted on the lower part. The protector itself will keep the beetle from that part of the tree, 
and the wash under the upper part of the protector will repel the mother beetle from crawling inside the protector.

\section{THE PEAR AND CHERRY SLUG. (Eriocampa cerasi).}

The pear and cherry slug wasp lays her eggs usually in the latter part of May or the first part of June, on the leaves of the pear and cherry tree. The larva when first hatched is of a greenish color, gradually turning to a shiny black as greater size and age are attained. The larva when full grown is about three-fourths of an inch long and is covered with a slime something like a snail, to which dust and dirt will readily adhere. It feeds mostly on pear, cherry and quince, eating away the pulp on the top side of the leaf. It very seldom eats entirely through the leaf; yet it causes the leaf, if badly eaten, to wither away and dry up. In some years these pests are very destructive.

\section{REMEDY FOR PEAR AND CHERRY SLUG.}

While the pear and cherry slug is very easily controlled with an application of arsenic (Remedies Nos. 2 and 3, or No. 4), it so happens that with cherries it appears just about picking time, when it is not desirable to spray, as this would cover the fruit with spray and injure its appearance for market. The slug is now found in all fruit sections and can be expected to appear nearly every year, and therefore any grower having cherry trees should spray with an arsenical spray at least a month before picking time, thus having the poison ready for the insect without injury to the fruit. The pear and quince can be sprayed at any time. If only a few trees are in the orchard, frequent applications of fine road dust, ashes or air-slaked lime are effective, as such substances adhere to the insects and dry them up.

APPLE OR GREEN APHIS.

The apple or what is commonly called the green aphis 
is the most conspicuous and probably the most troublesome of the aphis family. That they do serious injury at times, especially to young fruit trees, camnot be questioned. The egg is laid in the late fall season by the mother insect, mostly on apple and pear trees. If on the apple, you may look for them near the ends of last season's growth. If on the pear tree you may look for them on somewhat larger limbs and in and around the crotches. When first laid they are of a greenish brown color, gradually turning to a shiny black. They winter over in this stage and the eggs begin hatching with the early warm days of spring. They have been noted already hatched as early as the 11th of February, and the insect has been known to lay eggs as late as the 25th of December. The insect soon inserts its proboscis and begins sucking the sap of the tree or plant. It is wingless, and usually remains so, but grows rapidly and soon begins to produce living young. It is sometimes called a "stem-mother" because it is the source from which numerous generations issue during the season. All the young born of this stem-mother are. like herself, without sex; that is, they are neither males nor sexually developed females. The rate at which they are born varies, but as many as eight living young have been born from a single specimen in twenty-four hours and it is common to find a great cluster of ten or twenty of the young ones clustering around the mother louse. The conditions of the weather have much to do with the increase of this insect. Warm, damp weather is most favorable to its rapid increase, while cold, frosty weather in early spring is unfavorable and sometimes has much to do with checking and reducing the sum total for the season. Under favorable conditions the young that were first brought forth are in turn ready to reproduce in six or eight days; and thus it will be seen that many generations are brought forth in a season. In almost any generation after the first, a portion of the individuals may become winged and fly to other plants or trees and there form into colonies. Just what causes some of them to become winged and others to remain wingless is not known; but whether winged or wingless they are all equally without sex during 
the entire summer months. Upon the appearance of cold weather in order to provide for the continuation of the species during the winter months sexed forms are developed, and in a few days the egg laying season is on and thus the cycle of life and reproduction is completed.

We have a great variety of aphis and each variety has a host plant upon which to feed; and what has been said of the apple or green aphis holds good in a measure for all the others. They all winter in the egg state except the woolly aphis, which winters, in both the live and egg state, on the roots of the apple tree mostly. There are two forms of them, the branch form and the root form. However, they are one and the same kind of insect. The fact that they work down the roots deep into the ground makes it more difficult to control them and in some cases they become very numerous and do serious damage to young fruit trees, sapping away the juices of the roots and leaving the tree in an enfeebled condition.

We also have the plum or prune aphis and the peach and cherry aphis, which at times do considerable harm. The eggs of the plum, peach and cherry aphis are not so large and prominent as the eggs of the green apple aphis and are laid in more secluded and sheltered places and are therefore not so easily found and recognized.

Many other kinds of aphis of minor importance are found and some of these species are very numerous on shade and forest trees.

There are several types of natural enemies to the aphis in Idaho; the principal ones are Ladybugs (ladybirds), Syrphus Flies, Lace-Winged Flies and Parasitic Flies.

Use lime and sulphur solution (Remedy No. 1) during the dormant season, for destroying the eggs and whale oil and kerosene or whale oil and quassia chips (Remedies No. 6 or No. 8) for summer spraying.

THE WOOLLY APHIS OF THE APPLE. (Schizoneura lanigera Hausmann).

GENERAL APPEARANCE AND METHOD OF WORK.

Throughout the summer on the lower portion of the 
trunk and particularly on the water sprouts of the apple may often be seen small bluish-white flocculent or cottony patches, which indicate the presence of colonies of one of the worst enemies of the apple, viz.: the insect variously known in this country as the "apple-root plant louse," "woolly apple louse," "woolly aphis," etc., and abroad very generally as the "American blight." It exists in two forms, the one just referred to, above ground on the trunk or water shoots, and another inhabiting the roots and not open to observation. Closely paralleling in these particulars the grape phylloxera, the damage from the woolly aphis is also almost altogether due to the root form, the aerial colonies causing scarcely any injury. On the roots its attacks induce enlargements or galls or swellings very similar to those produced by the phylloxera, and in the cracks of these galls and swellings the root form occurs in clustered masses. The injury to the trees is due both to the sucking up and exhaustion of the vital plant juices, and to the poisoning of the parts attacked, as indicated by the consequent abnormal growths.

The damage is particularly serious in the case of nursery stock and young trees and is less often important after the tree has once become well established and $o_{\perp}$ some size. Where the insect is abundant all the roots of a young tree to the depth of a foot or so become clubbed and knotted by the growth of hard, fibrous enlargements, with the result, in a year or two, of the dying of the rootlets and their ultimate decomposition with attendant disappearance of the galls and also of the aphides, so that after this stage is reached, the cause of the injury is often obscure. On the trunks the presence of the aphides sometimes results in the roughening of the bark or a granulated condition which is particularly noticable about the collar and at the forks of branches or on the fresh growth around the scars caused by pruning, which latter is a favorite locaiton. On the water shoots the insects collect particularly in the axils of the leaves, often eventually causing them to fall, and on the tender greener side of the stems. The damage above ground, though commonly insignificant, is useful as an indication of the probable existence 



Fig. 1-F, The Cottony Maple Scale, Natural size.
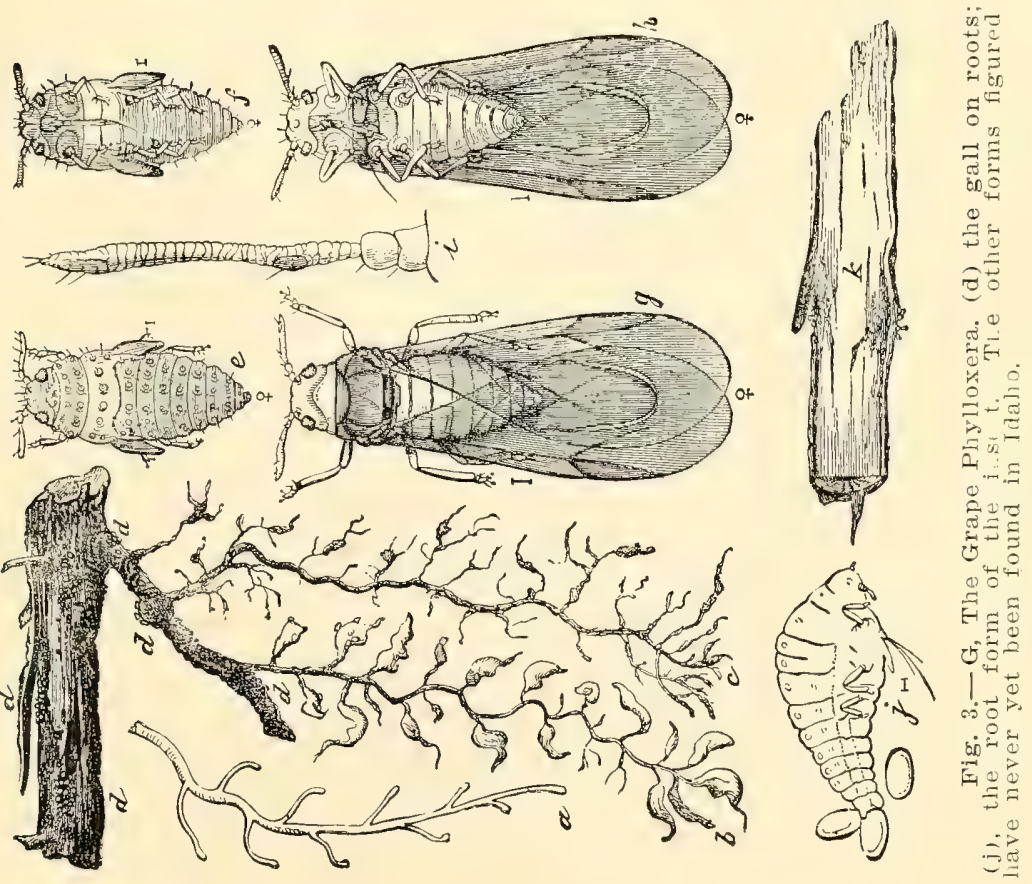

of the aphides on the roots. A badly attacked tree assumes a sickly appearance and does not make satisfactory growth and the leaves become dull and yellowish, and even if not killed outright it is so weakened that it becomes especially subject to the attacks of borers and other insect enemies. Injuries from the woolly aphis are almost altogether confined to the apple, even the wild crab not being so liable to attack or at least injury by it. There is, however, some difference exhibited by different varieties of apple in immunity, and particularly is the Northern Spy proof against it, and it is possible that, as in the case of the grape phylloxera, by employing root stock from seedlings of the more resistant varieties or from wild crabs, considerable protection would result. The character of the soil also exerts some influence-that is, loose dry soils are favorable and wet compact ones are unfavorable to the aphis.

\section{ORIGIN AND DISTRIBUTION.}

There is considerable difference of opinion as to the origin of the woolly aphis of the apple. The belief has fluctuated between a European and an American origin for this insect, but the weight of evidence seems to indicate the latter. At any rate, it is an insect which is most readily carried from place to place with nursery stock of the apple, and it has been so transported to practically all the important countries of the world which have been reached by colonization or European settlement. The woolly aphis was first noticed in England in 1787, on some stock imported that year from America, and was early called the American blight. Hausmann described it in 1801 as infesting apple trees in Germany, and within the next twenty-five years it was recognized as a serious enemy of this fruit tree throughout England, Belgium, northern France, and Germany, but it seems never to have been especially notable in the warmer latitudes of Europe.

It was very early introduced into Australia and New Zealand, and it is known in India and Chile, and probably is as widespread as any of the common injurious fruit 
pests. Notwithstanding the possibility of its being a native American insect, it did not attract attention in this country much before 1850. Its spread since has, however, been rapid, and it now occurs practically wherever the apple is grown. It has been reported to this Bureau from no less than thirty-five states and territories and nearly one hundred localities. It is particularly abundant and injurious in the latitude of the Ohio valley. While seemingly, therefore, somewhat affected by severe cold, it is able to thrive in the climate of the northern tier of states on the one hand, and in that of Louisiana, New Mexico and southern California on the other.

\section{NATURAL HISTORY AND HABITS.}

In common with most aphides, this species has a complicated life history, some of the details of which are still lacking. The common forms, both on the roots and above ground, are wingless aphides, not exceeding one-tenth of an inch in length, and of a reddish-brown color, and abundantly covered, especially in the aerial form, with a flocculent waxy excretion. These are so-called agamic females and reproduce themselves by giving birth, as observed by many entomologists, to living young indefinitely, perhaps for years, without the intervention of other forms. The newly-born larvæ have none of the white excretion, which, however, soon appears as a minute down when they begin to feed. These aphides are also peculiar in lacking the honey tubes common to most aphides, but exude the honey-dew from the tip of the body. In October or November, or earlier in the south, among the wingless ones numbers of winged individuals appear, which are also all females, and are the parents, as shown by the observations, partly unpublished, of Messrs. Howard and Pergande, of a true sexed generation of minute, wingless larviform aphides, the females of which, as in the case of the grape-root aphis, give birth to a single "winter egg." The egg is attached within a crevice of the bark, and, probably, following the analogy of the phylloxera, hatches in the spring into a female aphis which originates a new aerial colony. 
The winged females appear somewhat abundantly in autumn, and are one of the means of the dispersal of the insect. They are very minute, clear-winged, gnat-like objects, greenish-brown, almost black in color, with the body covered with more or less of the cottony excretion.

The aerial colonies are probably killed out every winter in the colder northern districts, but in the warmer latitudes the partly grown individuals, at least, survive protected in crevices or under bits of bark, and remain more or less active during winter and renew the colonies the following spring. This has been shown to be true in the District of Columbia, and also in the interior regions of the same latitude, in spite of the much colder winters. The root form survives the winter usually in an immature condition, viz.: larvæ in various stages of development, and both in latitudes where the aerial forms are killed by the severity of the winter and elsewhere it seems probable that there is a regular upward migration in spring and early summer from the roots, the aerial colonies appearing first near the crown and at a later period on the higher parts of the trees. At any time during the summer and fall there may be migrations to the roots, and throughout the year the subterranean colonies are maintained.

The spread of the insect is accomplished in part by the viviparous females, which appear in late summer, but quite as commonly perhaps by the transporting of young or partly grown individuals from tree to tree or to distant orchards by means of birds or insects to which they have attached themselves. Its wide distribution is usually dependant on the traffic in nursery stock.

\section{REMEDIES AND PREVENTIVES.}

The foregoing account of the habits and characteristics of the woolly aphis will enable us to suggest certain measures to control it. The aerial form presents no especial difficulty, and can be very readily exterminated by the use of any of the washes recommended for aphides, such as kerosene emulsion, a strong soap wash, resin wash, etc., the only care necessary being to see that the wash is put 
on with sufficient force and thoroughness to penetrate the covering and protecting cottony excretion. If the wash be applied warm, its penetration will be considerably increased.

The much more important root form, however, is more difficult to reach and exterminate. No known remedy will absolutely eradicate the root form, but several remedies are very effective and will keep this aphis under control. When woolly aphis is found on nursery stock the stock should be destroyed and only clean trees planted. When found on older trees in numbers sufficient to cause damage, the best remedy is the lime and sulphur solution used in same strength as for the San Jose scale. The ground should be removed at the base of the tree, exposing the larger roots for a distance of a foot or two all around the tree. About five gallons of lime and sulphur spray should then be poured onto the roots and the dirt replaced. If the infestation is very bad there should be several applications during the season. One pound of lime dissolved in five gallons of warm water can be used in the same way. A liberal application of tobacco refuse placed around the tree a few inches under the surface of the ground is also highly recommended, but the lime-sulphur solution is unquestionably the best known remedy.

\section{THE GRAPE VINE PHYLLOXERA.}

(Phylloxera Vastatrix).

HISTORICAL. - The phylloxera is a native of the United States east of the Rocky Mountains, where it is found living upon the wild vines. It is a minute insect related to the scale insects and plant lice.

THE INSECT.- The phylloxera occurs normally in four forms :

1. The gall insect, or form of multiplication.

2. The root insect, or form of devastation.

3. The winged insect, or form of colonization.

4. The sexual insect, or form of regeneration.

The gall insect lives upon the leaves, and is the commonest form on the wild vines in the native habitat of the 
insect. It rarely occurs in California. In Europe it is found often upon American but rarely upon European varieties. It causes little swellings or galls upon the leaves and younger parts of the vine, which, though sometimes very numerous, do little permanent injury. The chief danger from the gall form is that it multiplies with astonishing rapidity and migrates from the leaves to the soil. Here it attacks the roots and gives rise to the root form, the "form of devastation" the one that finally destroys all the vines it attacks which are non-resistant. Every insect of the root form which reaches maturity lays about 25 or $30 \mathrm{eggs}$, each of which is capable of developing into a new egg layer needing no fertilization. As there are from five to seven such generations during the year, the increase in numbers is extremely rapid.

Sometimes during the summer, usually July or August, some of the eggs laid by the root insects develop into insects of slightly different form, called nymphs. They are somewhat larger than the normal root form and show slight protuberances on the sides, which finally develop into wings. These are the winged or colonizing insects, which emerge from the soil, and, though possessing very weak powers of flight, are capable of sailing a short distance, and if a wind is blowing may be taken many rods, even miles. Those which reach a vine crawl to the under side of a leaf and deposit from three to six eggs. These eggs are of two sizes, the smaller of which produces males, the larger females. The female, after fertilization, migrates to the rough bark of the two-year-old wood, where she deposits a single egg called the winter egg, which remains upon the vine until the following spring. The insect which hatches from this egg in the spring goes either to the young leaves and becomes a gall-maker, or descends to the roots and gives rise to a new generation of egg laying root-feeders. The normal and complete life cycle of the phylloxera appears then to be as follows. Male and female insects (one generation in autumn); gall insects (one-fifth of the first generation while the vines are in leaf); root insect (an unknown number of generations throughout the year); nymphs, which become winged 
insects (one generation in midsummer). The gall stage may be admitted, as it generally is in California, and insects which hatch from the fertilized eggs laid by the female go directly to the root and produce offspring, which are indistinguishable from the root form produced in the normal cycle. For how many generations the root form can exist and reproduce without the invigoration supposed to come from the production of the sexual form is not known, but certainly for four years and probably more.

All forms of the phylloxera are extremely minute, the root form being about one-twenty-fifth of an inch long when it reaches the adult egg-laying state, and little more than half this length when young and active. It is just large enough to be seen by the unaided eye in a good light when its appearance is known, and, by the help of a glass magnirying five diameters, its legs and antennæ are plainly visible. Its color is light greenish yellow in summer, and somewhat darker in winter; so that when numerous attacked roots appear as though dusted in spots with powdered mustard or cinnamon. The newly hatched insect is fairly active, and at first moves about from place to place on the roots; but finally, when it reaches the egglaying stage, it inserts its sucking-tube into the root and remains fixed.

NATURE OF INJURY.- The amount of nutriment taken from the vine by such minute insects, even when present in the immense numbers in which they sometimes occur, is not sufficient to account for the disastrous effect upon the plant. The death of the vine is due to the decay which sets in wherever the phylloxera has attacked the roots. Wherever a phylloxera inserts its sucking-tube a swelling is produced, composed of soft tissue which soon decays. When this swelling ocurs at the end of a young rootlet, growth in length is stopped; when it occurs on the larger roots a kind of "cancer" or decay spot is finally formed, which soon extends around the root, and all that portion of the root below the point of attack dies.

During the first year or two after the vine is attacked there is little apparent damage. In fact, the effect of the attack of the phylloxera is equivalent to root pruning, and 
in some cases results in an unusually large crop of grapes. The year after this crop, however, the vine having endured the double strain of heavy bearing and root injury, is unable to recuperate and generally dies. In rich, moist soil the death of the vine is not so sudden, and two or even three small crops may be obtained after symptoms of the disease are evident.

So far as is known we have had phylloxera in but one locality in the state and that is in and around Juliaetta, Latah county. It occurs on the European varieties and so far as known it has only appeared as a root insect. A good portion of the vineyards have been pulled up and it has almost, if not entirely, been eradicated. It is well to be on the lookout for it, however, in the different parts of the grape growing districts.

\section{REMEDY FOR PHYLLOXERA.}

The gall form of phylloxera on American vines can be prevented by spraying the vines in winter with liquids to kill the winter eggs; but the treatment has no effect on the root forms, which in California hibernate abundantly in the soil. No cuttings should ever be used from an infected vineyard, and all vines within a radius of 50 feet from the infested vine should be dug up and burned, not allowing any vegetation of any kind to grow for a year or two. If a vineyard has become infested to any extent, the only sure remedy known is to destroy the infested vineyard. If the disease is allowed to continue it means the destruction of all vineyards in the neighborhood.

\section{THE CLOVER LEAF MITE.}

\section{(Red Spider).}

The clover leaf mite is more commonly known in the state as the Red Spider. It belongs to the sucking or haustellate species and is so small that it is hardly discernable to the naked eye. In shape it very much resembles the spider and it very often weaves an exceedingly fine and compact web, generally on the under side of the leafhence the name "Red Spider." 
The color of the insect is most often red, but it varies on different plants from almost a clear white to a brilliant red; so also with the color of the eggs. The insect is quite lively and moves about from place to place sucking the sap from the leaves of the plant. There are sometimes hundreds of them on a single leaf. They are worse on the prune tree than on any other of the fruits; but they inhabit nearly all kinds of shrubbery, plants and vines. They are especially bad on rose bushes and sweet peas. They are sometimes very troublesome on house plants.

The effect of their work may be easily noticed in the pale, sickly appearance of the plant upon which they feed. The fact that they inhabit so many different plants makes it very hard to bring them under control.

\section{REMEDY FOR THE CLOVER LEAF MITE.}

In order to destroy the clover leaf mite use lime and sulphur solution (Remedy No. 1) in the dormant season and whale oil and kerosene (Remedy No. 6) in the growing season.

\section{THE PEAR LEAF BLISTER MITE.}

The pear-leaf blister mite appears in early summer and causes thickened reddish spots and blotches on the leaves of the pear. Later in the season these spots die and turn brown, sometimes causing the foliage to drop prematurely. This pest proves serious on individual trees but does not spread very rapidly.

REMEDY FOR THE PEAR LEAF BLISTER MITE.

As a remedy for the pear leaf blister mite the use of lime and sulphur solution (Remedy No. 1) in dormant season will prove effective. 



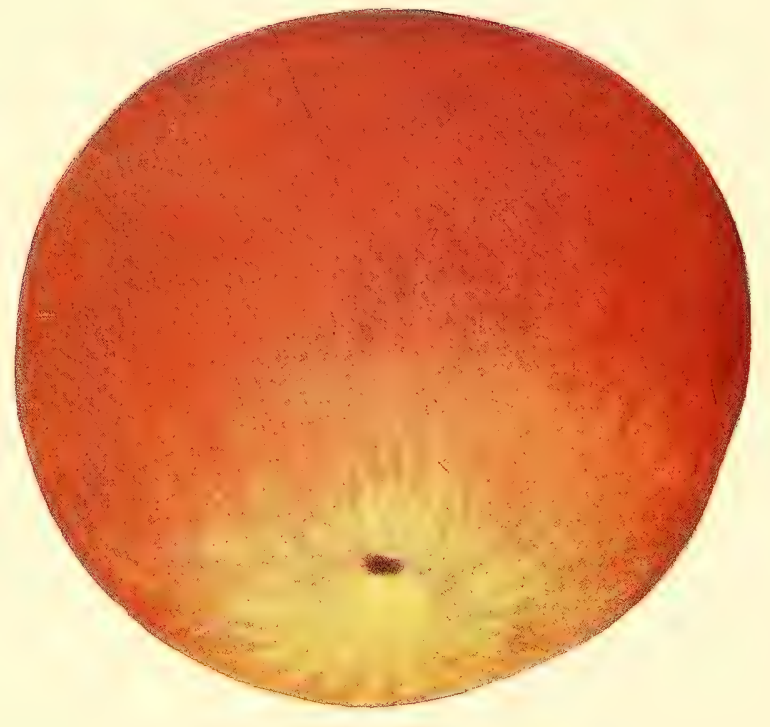

WEALTHY 


\title{
CHAPTER XV.
}

\section{PRINCIPAL FUNGUS DISEASES OF FRUITS IN IDAHO.}

\author{
COMPILED BY J. U. MCPHERSON.
}

\section{THE CAUSE AND PREVENTION OF PEAR BLIGHT.}

There is probably no disease of fruit trees so thoroughly destructive as pear blight, or fire blight, which attacks pears, apples and other pomaceous fruits. Some diseases may be more regular in their annual appearance, and more persistent in their attacks on the fruits mentioned, but when it does appear pear blight heads the list of disastrous maladies. Again, no disease has so completely baffled all attempts to find a satisfactory remedy, and, notwithstanding the great progress made within the last ten years in the treatment of plant diseases by spraying or otherwise, pear blight has until recently continued its destruction unchecked.

\section{WHAT IS PEAR BLIGHT?}

Pear blight may be defined as a contagious bacterial disease of the pear and allied fruit trees. It attacks and rapidly kills the blossoms, young fruits, and new twig growth, and runs down in the living bark to the larger limbs, and thence to the trunk. While the bacteria themselves rarely kill the leaves (at the most only occasionally attacking the stems and midribs of the youngest ones) all of the foliage on the blighted branches must, of course, eventually die. The leaves usually succumb in from one to two weeks after the branch on which they grow is killed, but remain attached, and are the most striking and prominent feature of the disease.

The most important parts of the tree killed by the blight are the inner bark and the cambium layer of the limbs and trunk. Of course, when the bark of a limb is 
killed, the whole limb soon dies, but where the limb is simply girdled by the disease, it may send out leaves again the next season and then die. All parts of the trees below the point reached by the blight are healthy, no more injury resulting to the unaffected parts of the tree than if the blighted parts had been killed by fire girdling.

Blight varies greatly in severity and in the manner in which it attacks the tree. Sometimes it attacks only the blossom clusters or perhaps only the young tips of the growing twigs; sometimes it runs down on the main branches and trunk; and again it extends down only a few inches from the point of attack. The sudden collapse of the foliage on the blighted branches has led many to believe that the disease progresses more rapidly than it really does. It rarely extends further than two or three inches from the point of attack in one day, but occasionally reaches as much as one foot.

It is an easy matter to determine when the disease has expended itself on any limb or tree. When it is still progressing, the discolored, blighted portion blends off gradually into the normal bark, but when it has stopped there is a sharp line of demarkation between the diseased and healthy portions.

\section{CAUSE OF THE DISEASE.}

Pear blight is caused by a very minute microbe of the class bacteria. This microbe was discovered by Professor T. J. Burrill in 1879 , and is known to science as Bacillus amylivorous. The following are the principal proofs that it causes the disease: (1) The microbes are found in immense numbers in freshly blighted twigs; (2) they can be taken from an infected tree and cultivated in pure cultures, and in this way can be kept for months at a time; (3) by innoculating a suitable healthy tree with these cultures the disease is produced; (4) in a tree so innoculated the microbes are again found in abundance.

LIFE HISTORY OF THE MICROBE.

Blight first appears in spring on the blossoms. About 
the time the tree is going out of blossom certain flower clusters turn black and dry up as if killed by frost. The blighting of blossoms or blossom blight, as it is called, is one of the most serious features of pear blight. One of the most remarkable things about this disease is the rapidity with which it spreads through an orchard at blooming time. The microbes travel about quite readily, notwithstanding the fact that they are surrounded and held together and to the tree by sticky and gummy substances. They are able to live and multiply in the nectar of the blossom, from whence they are carried away by bees and other insects, which visit the blossoms in great numbers for the honey and pollen. If a few early blossoms are affected, the insects will scatter the disease from flower to flower and from tree to tree until it becomes an epidemic in the orchard. From the blossoms the disease may extend downwards into the branches or run in from lateral fruit spurs so as to do a great amount of damage by girdling the limbs. The blight also gains entrance through the tips of growing shoots. In the nursery, when trees are not flowering, this is the usual mode of infection. This is often called twig blight, a good term to distinguish it from blossom blight, provided it is understood that this simply indicates different modes of attack of the same disease.

\section{CONDITIONS AFFECTING THE DISEASE.}

The severity of the attacks, that is, the distance which the blight extends down the branches, depends on a number of different conditions, some of which are under the control of the grower. It is well known, however, that the pear and quince are usually attacked oftener than the apple. Some varieties of pears, like Duchess and Keiffer resist the disease much better than others, such as Bartlett, Idaho and Clapp's Favorite. It may be stated in a general way that the trees most severely injured by blight are those which are healthy, vigorous, well cultivated, and well fed, or, in other words, those that are making rapid growth of new, soft tissues. Climatic conditions greatly 
influence the disease, warm, moist weather, with frequent showers favoring it; dry, cool and sunny weather hindering it; and very dry weather checking it to a considerable degree.

The pear microbe is a very delicate organism and cannot withstand drying for any length of time. In the blighted twigs exposed to ordinary weather it dries out in a week or two and dies. It causes the greater part of the damage in the month or two following blossom time, but twig blight may be prevalent at any time through the summer when new growth is coming out. In the nursery severe attacks often occur through the summer. In the majority of cases, however, the disease stops by the close of the growing season. At that time the line of separation between the live and dead wood is quite marked, and probably not one case in several hundred would be found where the diseased wood blends off into the healthy parts and the blight is still in active progress. In the old dried bark, where the disease has stopped, the microbes have all died and disappeared.

Unless the microbes keep on multiplying and extending in the tree, they soon die out. In certain cases the blight keeps up a sort of slow battle with the trees through the summer, so that at the close of the season, when the tree goes into a dormant condition, active blight is still at work in it. This is also true of the late summer and autumn infections. In these cases the blight usually continues through the winter. The germs keep alive along the advancing margin of the blighted area, and although their development is very slow, it is continuous. Probably the individual microbes live longer in winter. At any rate, the infected bark retains its moisture longer, and generally the dead barks contains living microbes during a much longer period that it does in summer. It has already been found that this microbe stands the cold well.

When root pressure begins in early spring the trees are gorged with sap. Under these favorable conditions the microbes which have lived over winter start anew and extend into the bark. The new blight which has developed in winter and spring is easily recognized by the moist 
and fresh appearance of the blighted bark, as contrasted with the old, dead, and dry bark of the previous summer. The warm and moist weather which usually brings out the blossoms is particularly favorable to the development of the disease. At this time it spreads rapidly, and the gum is exuded copiously from various points in the bark and runs down the tree in a long line. Bees, wasps and flies are attracted to this gum and undoubtedly carry the microbes to the blossoms. From these first flowers it is carried to others, and so on till the blossoms are all killed or until the close of the blossoming period. Even after the blooming period it is almost certain that insects accidentally carry the blight to the young tips and in this manner are instrumental in causing twig blight also. The key to the whole situation is found in those cases of active blight (comparatively few) which hold over winter. If they can be found and destroyed, the pear blight question will be solved, for the reason that without the microbes there can be no blight, no matter how favorable the conditions may be for it; or to use a common expression, there will be none left for seed.

\section{REMEDY FOR PEAR BLIGHT.}

There is but one known method of controlling pear blight up to the present time, and that is the judicious use of pruning knife and saw. All shoots, limbs, fruit spurs or twigs that show the least signs of this dread disease should be cut out very soon, lest the disease should become epidemic and cause great damage to the orchard. The cut should be made a foot below the part affected, if possible, and the saw or knife used should be disinfected after each cut by dipping it into kerosene, a weak solution of carbolic acid water, or a solution of corrosive sublimate, one part to 500 of water. All large wounds should be immediately painted over, to keep out the infectious germs.

\section{APPLE SCAB.}

Apple scab is perhaps the most destructive fungus enemy of the fruit growers in the northern part of the 
state, owing to the greater amount of moisture and more humid atmosphere, occupying among diseases" a position ranking with that of the codling moth among the insect foes of the apple. It very seldom if ever occurs in the southern or arid parts of the state. Its injuries are greater than are generally appreciated, both in effect and extent. The yield of fruit per tree is greatly lessened whenever the scab is present: (1) By the premature dropping of young apples, due to the attacks, soon after the blossoms fall, of the scab fungus on flowers, stems and fruits; by the smaller size of the scabby apples that mature, and (3), by the loss, just before picking, due to the fact that scabby fruit does not cling well to the tree and is more easily blown off; (4) the value of the fruit harvested is greatly diminished, since spotted apples must be placed in a lower grade and sold for less than clean fruit; (5) their keeping quality is also impaired, as molds and other fungi, which cause decay, gain entrance through the scab spots and increase the loss during storage. Nor is the damage confined to the fruit. The leaves are also attacked by the fungus, and the resultant spotting and distortion considerably lessen the vigor and general health of the tree.

\section{CAUSE.}

Apple scab is caused by the summer or conideal stage of a fungus. This fungus attains its perfect form on dead apples leaves. The disease first appears on the leaves shortly after they unfold, the first infections having come from spores blown by the wind from the dead leaves of the previous season. The olive green, velvety spots on the leaves and fruit produce great numbers of spores, which continue to spread the scab broadcast. In the wet season the flowers and very young fruit and its pedicels are attacked. The fungus grows in this manner throughout the summer and autumn. In the late autumn and winter the Ventura or perfect stage is produced on the dead apple leaves on the ground.

The relative severity of the disease is influenced by a number of factors, chief of which is the weather. A low 
temperature and abundant moisture favor the development of the fungus, and consequently scab is worse in cool, damp seasons.

Cultural conditions in the orchards influence scab fungus as much as they do the codling moth. Neglected, unpruned and uncultivated trees are more subject to scab, and careful attention to the general condition of the orchard in connection with the spraying will always be profitable.

Varieties of apples differ in their susceptibility to scab, but susceptible varieties often possess counterbalancing desirable qualities which lead to their extensive use.

\section{REMEDY FOR APPLE SCAB.}

As multitudes of the spores of apple scab winter on the fallen leaves they should all be plowed under or raked up and burned. All prunings and twigs should be carefully gathered and burned.

Use lime and sulphur solution (Remedy No. 1), just as the buds are beginning to open, as this is an excellent fungicide as well as an insecticide. It has long been the custom to use the Bordeaux mixture for this disease, the first application at the time of first spray for codling moth and every two or three weeks for three sprayings, or more if the season is cold and damp. While Bordeaux, if properly used, will kill the scab, it often causes a russeting of the fruit, which is nearly as serious as the disease itself. In the last four years experiments have been made to determine the practicability of using a weak lime and sulphur solution in place of Bordeaux and all tests so far seem to indicate that the proper remedy has been found, although later tests may bring forth developments not yet anticipated. This spray has been tested at various strengths but a concensus of opinion would indicate that home cooked mixture 5 pounds sulphur and 5 pounds lime to 50 gallons of water or prepared mixture in proportions of one part solution to 20 parts water would be about right.

While we have not had sufficient experience to unquali- 
fiedly recommend the lime and sulphur spray, we would advise growers in sections where scab is prevalent to make a thorough test the coming season, using lime and sulphur solution at strength given above at times and in manner as formerly used with the Bordeaux.

BROWN ROT OR FRUIT MOLD.

Description-This is the only serious fungus disease of the plum, prune, cherry and peach yet known in the orchards of the northwest, where it has become introduced within the last few years. Usually the first sympton of this disease to attract attention is the numerous grayishwhite pustules that appear on the attacked fruit when it is nearly ripe. The pustules consist of the reproductive bodies or spores of the fungus, and under the microscope are seen to be oval in shape and arranged in rows like chains of beads. The disease is scattered by these spores being carried by the air currents or in some cases by insects. Under favorable conditions the spores quickly germinate, sending out a germ tube that will penetrate a healthy fruit and soon cause it to rot. A curious feature of this fungus is that it causes the attacked fruit to become dry and hard, in which condition it may remain hanging on the tree for a long time. It is mainly on these fruits that the fungus passes the winter, and on such fruit the spores may be found in abundance in the spring. The disease spreads much more rapidly in damp weather than in dry, so that the amount of damage it does is much more serious in some seasons than in others.

REMEDY FOR BROWN ROT OR FRUIT MOLD.

Use lime and sulphur solution. (Remedy No. 1) at the first opening of the buds and Bordeaux mixture (Remedy No. 7) for summer spraying.

\section{LEAF BLIGHT OF THE PEAR.}

In connection with the discussion of the true pear blight it seems desirable to mention the leaf blight which 



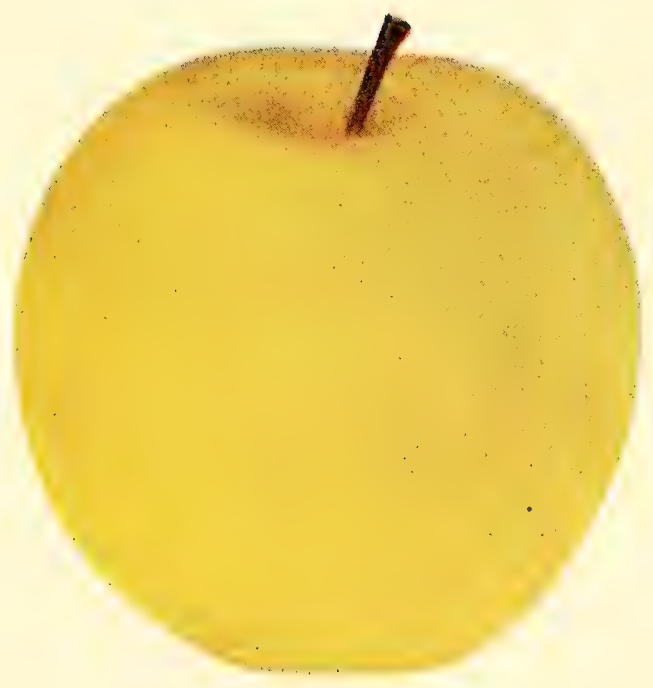

GRIMES GOLDEN 
is entirely distinct from the former disease. Leaf blight is caused by the fungus Entomosporium maculatum, while the true pear blight is caused by a bacteria or germ. Pear twigs attacked by true pear blight show curled and blackened leaves-this feature being very prominent, but usually the leaves themselves are not killed by the pear blight disease, but die as a necessary consequence, following the death of the twig to which it was attached.

Leaf blight is one of the most serious diseases of the pear, and is also frequently abundant on the quince. The blight first develops soon after the leaves become fully expanded in spring, appearing first as minute reddish spots on the upper surface of the leaves. As they increase in size and numbers considerable areas of the leaves may become involved by the fungus itself while the areas in between the spots become greatly weakened. The reddish spots soon change to a deep brown with dark center, finally becoming nearly black. With a magnifying glass minute black dots may be discovered in the center of the spots, these dots being the fruit or spores of the fungus. When leaves are badly affected it results in severe shedding.

Unfortunately leaf blight is by no means confined to the leaves but appears on both twig and fruit. The former are attacked much the same as leaves. The fruit first becomes covered with reddish pimples, soon changing to nearly black, while the diseased tissue begins to crack in such a manner as to ruin the fruit. Even when the pears attain full size, the cracking may be so severe that the fruit will be unsalable.

Hot, dry weather seems to be favorable to an increase of pear leaf blight, though the disease is liable to develop almost every season. When young, tender leaves are attacked, the result is that they become curled, due to a contraction of the diseased areas. Full grown leaves usually retain their shape even when completely covered by the black spots.

REMEDY FOR PEAR LEAF BLIGHT.

Use lime and sulphur solution (Remedy No. 1) as the 
buds begin to open and Bordeaux mixture (Remedy No. 7) for summer spraying. Several sprayings may be needed.

CROWN GALL, ROOT GALL, ROOT KNOT, HAIRY ROOT.

May be all the same disease yet assuming different types or forms. This fungus or bacterial disease appears mostly on apple trees but may occur on different varieties of deciduous fruit trees, plants and shrubs. It is very frequently found on nursery stock and is usually noted by the enlargement or knotted appearance of the roots. These abnormal growths, knots or galls may vary in size from a foot in length and diameter to very small excrescences un the fine roots. In the case of hairy root it may be noted by the great numbers of hair-like roots extending from the main base or tap root.

We deem that there is a possibility of infection from spores being driven by the wind or by contact from plant to plant.

All plants showing the least signs of the disease should be promptly condemned and burned up. The most careful and rigid inspection for the disease should be given all nursery stock before being planted.

\section{GOOSEBERRY MILDEW.}

This troublesome disease usually appears in the spring upon the developing buds and leaves, first showing as a sparse cob-webby coating, which later develops into a denser white, powdery coating. The young berries are also attacked. A serious disease which very much interferes with the growing of choice foreign varieties.

REMEDY FOR GOOSEBERRY MILDEW.

It has been ascertained by experience that Remedy No. 1 used in the dormant season has been most effective. If summer spray is needed, use Remedy No. 7.

PUSTULE SPOT FUNGUS.

This is a disease that has lately made its appearance in 
Idaho. It attacks the peach, apricot and nectarine. The markings on the fruit sometimes very much resemble the San Jose scale but a closer examination easily reveals the difference.

The pustule consists of a small blister or elevation of the cuticle or skin of the fruit. It sometimes assumes quite a scabby appearance. This fungus disease has undoubtedly been lately imported from some other state.

Use lime and sulphur solution (Remedy No. 1) in the dormant season and Bordeaux mixture (Remedy No. 7) for later spraying.

We also recommend Remedies No. 1 and 7 for powdery mildew of the peach, apple, grape and other fungus diseases. Remedy No. 1 must always be used in the dormant season and No. 7 for summer treatment. 



\title{
CHAPTER XVI.
}

\section{CONTROL OF PEAR BLIGHT.}

\author{
BY P. J. O'GARA.
}

Assistant Pathologist Department of Agriculture.

The germ causing this disease is named by bacteriologists Bacillus amylovorus. For our purpose of discussion we may call it the pear blight bacillus, the pear blight germ or the pear blight microbe, all these terms meaning practically the same thing. These germs are among the most minute of living things. Bacteria or germs are vegetable organisms and are as truly plants as trees, grasses, etc. However, they are very low down in the scale of the vegetable kingdom since the individual organism consists of a single cell, which may be elliptical or rod-like in form. They multiply by lengthening a little and then pinching to two. This is the only way in which they may increase their numbers. This process can take place within half an hour or less, and this I have proven by observation in a hanging drop culture under the microscope; although they are extremely minute they may be measured by means of microscopical apparatus. The standard of measurement for these minute objects is the micromillimeter, and a millimeter is about one twenty-fifth part of an inch. The pear blight germ is about two-thirds to three-fourths of a micromillimeter wice, and from one to one and onehalf micromillimeters long when it has reached its mature stage. As another illustration showing their minute size I may say that if 25,000 pear blight germs were placed end to end they would scarcely measure an inch in length. Curiously enough, the young germs are longer than the older ones. When they are growing rapidly their development in length goes on more rapidly than their division. This germ forms no spores, and for this reason cannot 
live over the dry season, as do the germs of anthrax, which form spores. The pear blight germ is very sensitive to drying, and, in fact, is a very short-lived germ. The fact that it does not form spores is highly important, as sporeforming bacteria are capable of living over in dust which may be blown about by the winds. The germ dies rapidly in the blighted tissues, as soon as the tissues have become fully killed. It cannot withstand drying, usually dying within two weeks or so. It is killed by exposure to direct sunshine in a very few minutes, usually not more than ten minutes unless protected by the bark or twigs. It rapicily dies when washed into the soil, since it can no longer gct the necessary food for its existence and multiplication. In fact, the pear blight germs disappear and die very shortly after they are exuded or washed out by the rains from the twigs and branches. It also dies when the blighted bark dries up. It can only live along the advancing margin of the disease in the thick, fleshy bark or cambium which has been invaded by the bacteria, and which does not have time to dry out until the cool weather approaches. The thick bark of the large limbs, branches and root system remains moist during a long period, especially in the winter. By this method, the importance of which we will show later, the germs are able to carry over, or live over, from one season to another. As a niatter of fact, it is only by this means that the pear blight can live over during the dormant period of the trees. The germs are killed by a high temperature, they are wholly destroyed when subjected in liquid culture to the temperature of $\mathbf{5 5}$ degrees Centigrade for ten minutes. They are wholly uninjured, on the other hand, by any degree of cold. Temperatures of 40 degrees Fahrenheit below zero have no effect whatever. They may be found to be frozen at this temperature, but thaw out immediately when plunged into warm water and go on with their activities uninjured. Cold retards their development, but it also prolongs their life. Like other vegetable organisms, cold storage has the effect of prolonging life over a long period of time. In the laboratory the organism lives for a relatively short time at room temperatures, while if the cultures are put into 
the ice box the germs may live for months providing the culture medium does not dry out.

In the life cycle of this germ, blossom blight may be considered the first step, at least, this is the first step in its life cycle that is noticed by the casual observer. For a long time it was a great puzzle where the germs came from that produced the first blossom blight in the spring of the year. This one link in the chain, where the germs remained during the dormant season, was missing. No one knew how the first blossoms became infected. Given a number of blossoms infected, it was comparatively easy to discover the methods by which the germs were carried about. Not only in natural infections but in those artificially produced with pure cultures, insects were found visiting the blighted blossoms. The germ multiplies in the nectaries of the blossoms as readily as it does in a culture medium, since the nectar glands exude a sugary solution which furnishes the organism the necessary food supply. The enzyme or ferment given off as a by-product by the germ dissolves the delicate cells beneath, permitting the germ to pass downward with the greatest of ease. Ordinarily the entire pear tree is sealed up with an air tight and water tight cuticle composed of a thin layer of the same composition as cork. Even the breathing pores are plugged up during the dormant season of the tree so as to prevent evaporation from the tissues. This cuticle keeps out the pear blight germ unless it is injured or broken. The nectary is not covered by cuticle, and is, therefore, an easy place for the germs to enter. The gummy exudate pushes out of the infected blossoms, adding to or even taking the place of the nectar; and honey bees, wild bees, wasps, flies, and perhaps fifty other species of insects visiting the pear blossoms or apple blossoms carry the germ-infected material. When once the insects' mouth parts and feet are infected, blossoms which it visits thereafter in turn become infected as the insects drop off a few germs into the nectaries. The blight virus being also a sticky material and usually requiring a considerable mass, speaking from the microscopic standpoint, to produce infection, is not blown by the wind. Of course, the negative 
of such a proposition is hard to prove conclusively, but experiments have been made to decide this matter by covering blossoms with mosquito netting along the side of artificially infected flowers, and it was readily found that the uncovered flower visited by insects contracted the blight, while those covered by bags, mosquito netting and other material which kept out insects remained free from the disease. Occasionally, a humming bird visited the infected blossoms. This has been observed in a number of instances. Doubtless birds get the gummy material on their feet and carry the blight long distances. However, we look upon insect distribution as by far the most immediate means of infection, especially in blossoms; in carrying the blight from flower to flower, tree to tree and orchard to orchard, although doubtless occasional long distance distribution is accomplished by birds or some other agencies, including man himself. After the blossoming period is over, or even before it is entirely finished, blight may be found attacking the tender twigs. Our common insects have been found to be active agencies in not only the distribution of the disease, but in puncturing the tissues and thereby introducing the germs into them. While it is easy to prove that insects cause some of the infections of some of the twigs, it is not absolutely certain that they do all the innoculating. Twigs are sometimes found with bligh started in the axils of the leaves or in the tender bark where no punctures can be found on careful examinatior It is possible that the germ may enter in damp weather through growth cracks where the cuticle is ruptured, exposing the tender tissues.

That insects really carry pear blight germs on their feet and mouth parts, I have proved by capturing these inserts in infected orchards and allowing them to walk about on prepared culture plates, known as Petri dishes, which contained a substance in which germs might make growth. In from 24 to 48 hours colonies of germs would be found growing from the points where the insects walked upon the culture medium. By innoculating growing shoots from these cultures, typical cases of blight were produced.

In the numerous experiments which have been made 



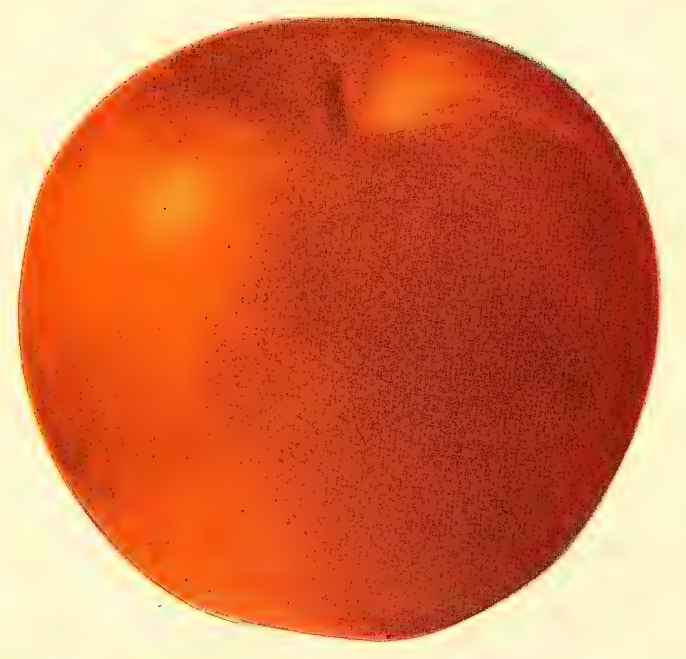

JONATHAN 
atomizing the germs on the tissues, it has resulted in a failure in most cases, except where punctures through the cuticle have been made by a pin point, or where ny the breaking of the leaf or some slight abrasion the skin has been ruptured, allowing the germ to eiter.

There are, therefore, two main methods of entry by the germ. First, in the nectar of the blossom, and second, in the tender tips of growing twigs or warer sprouts. Plight occasionally enters by the third method-directly into the tender, growing, fleshy part, through growth cracks, although as a general rule this method of entry is comparatively rare. Sapsuckers or woodpeckers become infected by puncturing cases of hold-over blight, and afterwards visiting healthy trees produce blight infection from them. We have several observations along this line and doubtless many more occur in nature. It is even possible for the whiffletrees or implements used in cultivation to transfer the infection; pruning tools are certainly a very frequent cause of transmitting the disease, especially during the growing season.

Mr. Waite states that in Maryland he saw a nursery block of 10,000 Bartlett pear trees completely destroyed by blight. This block, as was determined by the specimens, carried actual samples of hold-over blight in the stocks. When stocks were cut off above the dormant buds in the spring, the pruning tools became infected and the disease was transmitted to nearly every tree reached by the pruner. Instead of the buds pushing up, the cut surface began to gum and blight. The writer has seen in certain nurseries in Nebraska many cases where nursery infection has been brought about through the use of tools which have been used in cutting out blight infection in large orchard trees, without previously disinfecting them. Pear blight behaves in all sorts of irregular ways when it runs down the limbs and branches. Occasionally a fruit spur blighting causes the disease to spread in a circular spot an inch or two in diameter on the branches. More often it is an elliptical spot extending lengthwise of the branch. It may run down in a long line from the lower edge, making it very difficult to save the branch or even 
the tree by cutting, on account of this narrow strip of the disease. It is almost impossible to anticipate the variations in behavior of the disease, because it depends upon so many different factors. It may be well to point out some of the factors controlling the habits of the disease in order that you may see how varied are the influences controlling it.

These factors may be divided more or less completely into two sets. First, those which govern infection, and second, those which determine the spread of the blight in the tree after infection.

The first factor is the presence of the bacillus. The pear blight germ must be present in the orchard or must be carried there during the season in order to have the blight. No matter how favorable the conditions may be, unless the germ is there the disease cannot develop. The immunity of California and Oregon orchards up to recent years, of course, is attributed to the fact that the germ was not there The second factor is the number of insect visitors. We have pointed out that insects carry the blight about. The honey bee is one of the most active in carrying the blight on the blossoms. Other insects visit the pear and apple blossoms and carry the blight very widely. The presence of some certain species of insects as already suggested, has been the means of introducing the blight into the twigs and branches or bodies of the trees. Not only must the insect be present and the germs there for them to carry, but the weather conditions must be favorable for the activity of the insects and to bring the trees into proper condition for infection.

Flower visiting insects usually like sunshiny weather, especially sunny weather following a moist season, which allows many kinds to hatch out or develop from the pupa. Young orchards are not usually attacked by the blight, rather rarely, in fact, until they have blossomed, unless there is a bad attack of blight in a pear or other pome fruit orchard near at hand. There are some cases of young orchards which I have seen in California and Oregon that have blighted somewhat seriously before they had bloomed, but they were alongside badly blighted 
pear orchards. The presence of water sprouts or spurs from the French stock, on which pear trees are mostly budded, often determines infection. In many localities the entire loss of the pear orchards has come through the infection of water sprouts and spurs coming from the crown or roots of the trees. Perhaps 90 per cent of the loss in many of the river orchards in the Sacramento valley has come about through this sort of infection. Right alongside of orchards which have been seriously damaged through the infection of water sprouts from the stock or roots we found thrifty trees which were budded on Le Compte, Winter Nelis and Kieffer roots; these have not gone down with the disease through their ability to resist the blight. It has been particularly noticeable that Winter Nelis roots are very resistant to the blight. Cases have come under my observation where the bodies have blighted as far as the union with the Winter Nelis stock and then stopped. If this experiment proves universal, it is a strong argument in favor of using the Kieffer and Winter Nelis stocks on which to graft the more tender varieties. Furthermore, these stocks have a less tendency to throw out sprouts.

Several conditions or factors control the spread of the blight after it once enters the tree. Some of these are more or less connected with the conditions favoring infection. The vigor of the tree has a great deal to do with the amount of damage produced after the blight once enters it. Another fact which must be borne in mind is the variety of the tree, whether apple or pear, or any other pome fruit. All varieties are not equally susceptible under similar conditions, there being in many varieties a certain tendency or immunity. The more vigorous and thrifty the tree, as a general rule, the more seriously it is attacked by the blight. The vigor itself is the effect of various conditions, such as the fertility of the soil, the amount of manure or of fertilizer used, or kind of cultivation, soil, moisture, rainfall or irrigation, and the presence of other diseases, such as leaf blight, crown gall, root rot, etc.

As a rule, trees on rich soil blight more readily than trees which are on poor soil. There are some apparent exceptions to this, and there is a difference in the behavior 
of blight on different soils in connection with their fertility. Alkali soils seem to favor the blight more than correspondingly fertile soils that are not alkali. On the other hand, trees may blight on the acid soils of the eastern states. Stable manure causes the trees to be more susceptible to the blight than those not manured. The age of the tree also exerts an important influence. The older and slower growing the tree is the less it is attacked by blight, other things, of course, being equal. Exhaustive crops of fruit tend to consume the food material of the tree and help to check the blight to a certain extent. On the other hand, when the trees fail to fruit from unfavorable conditions, such as prolonged rains at the blossoming period, there may not be the opportunity for infection and the contradiction to this principle may be observed. From observation, orchardists know that during rainy and cloudy weather insect visitors, such as bees, are very rarely found working in the blossom. Since the bees are the principal distributors of the blight germs, it can be readily seen that if the entire blossoming period is covered by rainy or cool weather there is little chance for very serious and general infection, although there may be considerable hold-over blight in the vicinity of the blooming orchards.

The style of pruning the tree exerts some influence, not only in the behavior of the blight, but also on the convenience of the orchardist in eradicating the disease. The least desirable form of tree is the tall pyramid, having a central leader with the fruit spurs on the main trunk and water sprouts at the base. In this form of tree, any infection of blossoms or sprouts readily goes into the body, making it difficult to eradicate the blight without practically destroying the tree, or, at least, removing the principal bearing area. The most desirable form is the broad vase-formed tree, clean and free from water sprouts at the base, having no fruit spurs near the main trunk and leaders, and having lateral twigs for fruit bearing at as great distance as possible from the crown of the tree. Such a tree is also in a very desirable form for other reasons, for it is easier to spray, easier to prune after the top has been formed, easier to gather the fruit, and especially easier to examine and keep free from blight. 
The weather at critical times, especially in the spring and summer, exerts an important influence on the spread of the blight. In fact, the weather influences dominate more equally the infection than they do the spreading of the blight in the trees. We recognize certain spells or weather conditions as infection periods, and by following carefully the relation of the blight to the weather the intelligent fruit grower soon learns to anticipate these difficulties. In fact, it is supposed by many that the long, dry, hot summer of the western states, especially the Pacific coast states, gives such poor opportunity for pear blight that it was not able to exist under the prevailing conditions. Of course, we now know that this is a fallacy, for, as soon as the germ was introduced, it produced the disease abundantly. Dry sunshine, while favorable to the orchards, tends to produce a firm, healthy growth of the tree and prevent infection periods. However, constant and intense sunlight produces another result which may be noted here. Pome fruits, as well as other fruits, under the influence of dry, but sunshiny weather, carry on their processes of growth and assimilation in the very best possible manner. The study of blight throughout the west shows that where irrigation is used on the one hand, and where there is a natural supply of water on the other hand, and where the orchards are fairly well supplied with water and kept in a continual state of high nutrition by the perpetual and uniform sunshine, the trees are peculiarly susceptible to the disease. In the lower Sacramento valley in California and in the Rogue River valley where irrigation is not resorted to, we find that there is a great deal of soil moisture, and in many favored spots, the water table is only a few feet below the surface of the ground. Under proper cutivation, where a dust mulch prevents evaporation of the soil moisture, we find that during even the dryest seasons the roots of the trees are amply supplied with water. On the other hand, we also find places where the water table is too near the surface, and in this case the trees are in a drowned condition; consequently, perfect assimilation does not go on, and for this reason, such trees, although situated in rich, nitrogenous soils, do 
not blight badly. Where the trees are growing at their best, the blight germ feeds on the rich sugars and starches of the sap, so that the conditions which favor the growth and production of the fruit also tends to favor the germ; for we must remember that the germ is itself a plant, depending upon the rich food supplied by the tree for its best growth. The fleshy bark of trees grown under constant sunshine, especially those of the Pacific coast, seem to be richer and thicker than in the eastern states, and naturally affords an unusually good feeding ground for the pear blight bacillus. This rich, fleshy bark also tends to hold over the germ during the dormant season in a much more serious way than the thinner bark of trees grown under other conditions. Cloudy, rainy weather, therefore, while favoring infection, sometimes results in a starved condition of the tree, which, of course, is especially unfavorable to the pear blight germ. Trees grown so as to produce a minimum growth naturally are short of plant food, and, of course, do not favor the pear blight germ, even though it should enter the tissues. Every physiologist knows that in order that a green plant may form starch in its foliage the action of sunlight is required. The more intense the sunlight the more rapidly the formation of starch goes on. In cloudy, dark weather, very little starch is made or elaborated in the leaves. Of course, we know that the tree does not make use of its starch as such, but, through the action of a diastatic ferment or enzyme, the starch is changed into sugar, which is translocated to all parts of the tree by osmotic action, that is, through the sap. It is this rich sap, which is mostly sugar, that the pear blight germ feeds upon. The more sugar, the more intense the destructive action of the germ. The very regular growth of the trees in the Rocky Mountain and Pacific Coast orchards tends to keep the pear blight germ continually at work, unless checked by prompt and thorough eradication. In the eastern orchards, especially with dwarf pears, which make their growth early in the season, a heavy rain, if accompanied by a day or two of cool, cloudy weather, will cause the trees to close up their terminal buds. 
Before leaving the chapter on weather conditions, it may be well to point out more fully the reasons why serious outbreaks of blight occur after showers or thunder storms. It has been the common belief that static discharges of atmospheric electricity have a considerable influence upon such outbreaks. This, of course, is mere fancy and has no scientific significance whatever. Everyone knows that a seed planted in dry soil cannot germinate unless moisture is applied to it, either artificially or naturally. Now, supposing a thunder storm comes along with a heavy precipitation, or at least sufficient precipitation to moisten the soil about the seed; what happens? The question is so simple that a child in the primary grade would not hesitate in answering it. Of course, the seed starts into growth, the rapidity of its growth depending upon the temperature following the rainfall. Now, was it the rainfall or the thunder and lightning that caused the seed to germinate? No, the rainfall and the warmth, and nothing else. It has been explained that a germ or bacterium is also a plant dependent upon moisture and heat for its growth. In a dry season an enormous number of infections may take place, but the very fact that the season is dry and warm accounts for the fact that these infections fail; just the same as in a very dry season a very large percentage of corn, or any other seed put into dry ground, will fail to germinate and we have an occasional plant coming up, just as we find in the case of blight, only a few infections appearing. Everybody knows that after a rain every vegetable starts into rapid growth providing the weather is warm. Now, rapid growth in a pear or apple tree means nothing more or less than an enormous addition of water, plus food from soil and air to it. Here we have conditions favorable to the growth of the blight germ which uses the pear or apple as its soil from which it draws its water supply and its necessary food; namely, starch and sugar. Just preceding a heavy rainfall, the germs may have been distributed very widely. Had dry weather continued the fact that the germ had become widely distributed would not have become apparent because countless infections would not have taken. In very dry 
weather, the nectaries of blossoms soon dry, and unless germs have gained a strong foothold before drying takes place no apparent infection results. The above explanation should suffice to show that the thunder and lightning theory has no bearing whatever on the disease known as pear blight. Consider the germ in the light of a seed whose germination is dependent upon the same ecologicaı conditions for all of its growth activities.

To one who knows something of the theory of the disease, the matter of eradication often seems very simple. It is usually a very easy thing to write about the experiences of others and to tell in considerable detail how blight should be eradicated and controlled. The actual field work is very difficult and tedious, and a matter of days and months of training only will make an expert field man. No one can become expert after a few hours' work, even under competent instruction given by a trained man having had years of experience. We do find people, however, who are able to write and instruct without having had any experience whatever. To the initiated, as well as the uninitiated, let me say that the eradication of pear blight is one of the most difficult problems known to plant pathologists. Let no one say that it is a simple thing. It is difficult, very difficult. The reason for this difficulty is that we are dealing with a considerable amount of ignorance and unbelief; again, few farmers who have not had a bacteriologist's training, realize the peculiar relation existing between the organism causing the disease and the host of plants. They fail to see that this relation is practically the same as that which exists between the germ of tuberculosis and man. On the one hand, antiseptic precautions, and the removal of infections seems unimportant; on the other hand, however, long experience with this dread human disease instills a sort of fear, even though the true cause may not be fully comprehended. If very fruitgrower could be made to feel that fruit trees are living things very much in the same sense as themselves, and that the parasites attacking them should be viewed in a corresponding light for both, I am sure the whole matter of education would be solved. 


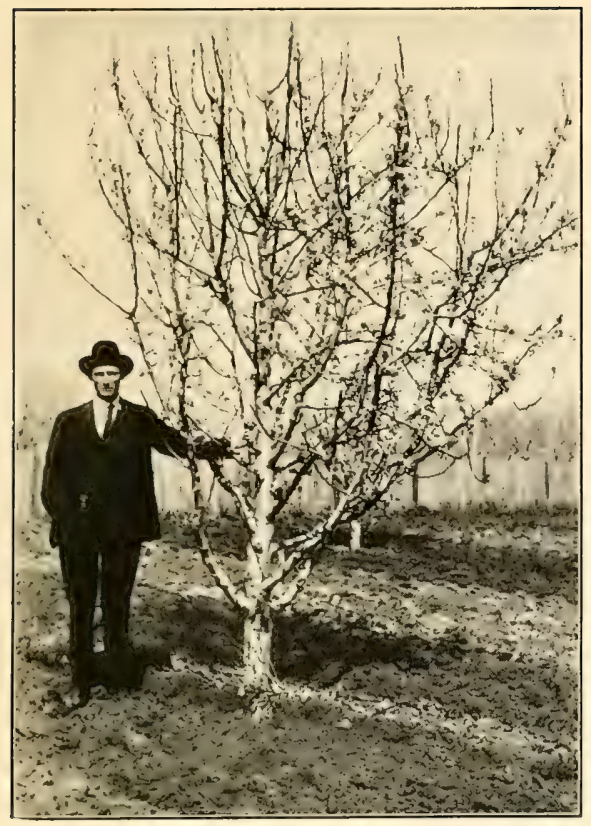

Figure 1-Wrong form of pear tree. The central leader renders it difficult to lead is the proper type of tree. (Pinutograph by the author).

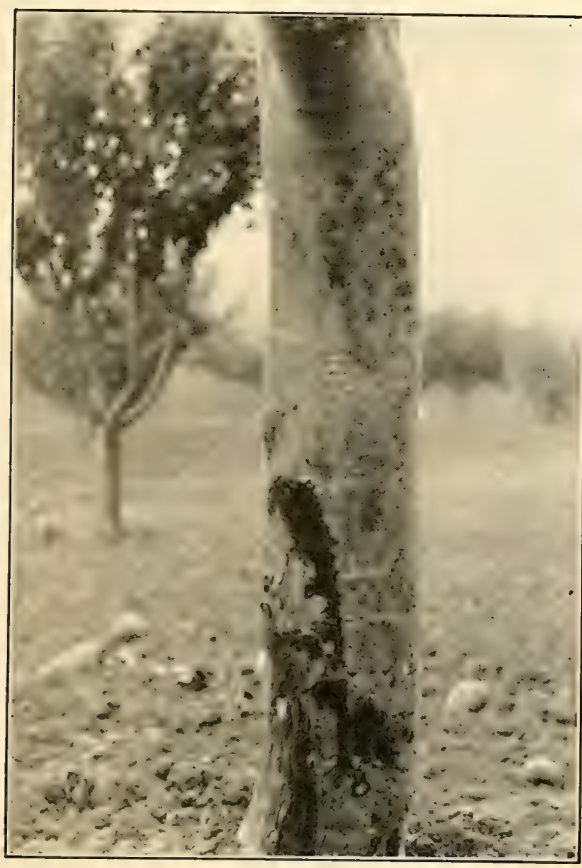

Figure $3-\mathrm{A}$ bad crown infectiun on Spitzenberg apple, due to wacer sprouts. Poor attempt at working out the infec tion. Note ooze running down the body above the part cut out. (Plotograph by the author)

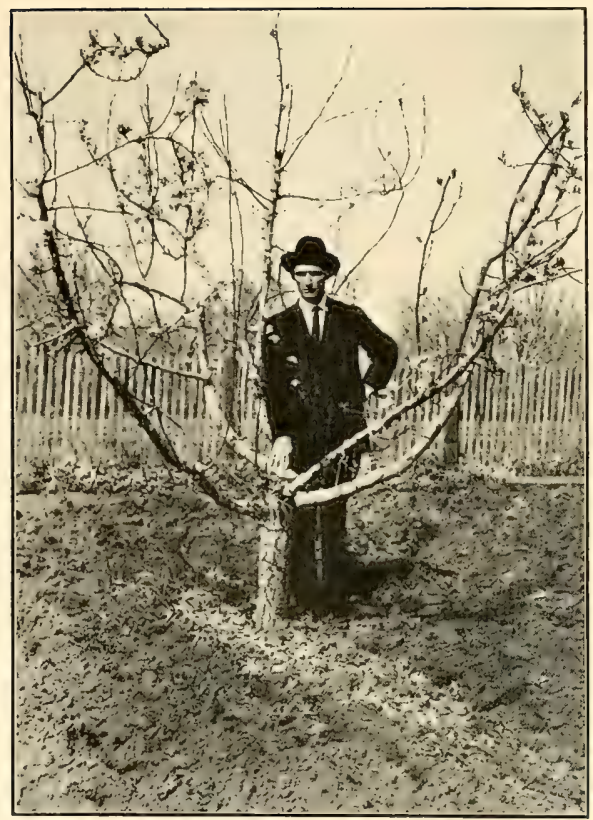

Figure 2-The result of srowing a tree with the central leader. Hlisht infec tically the entire bearing area of the tree. The limbs left are too long and weak. (Photograph by this author).

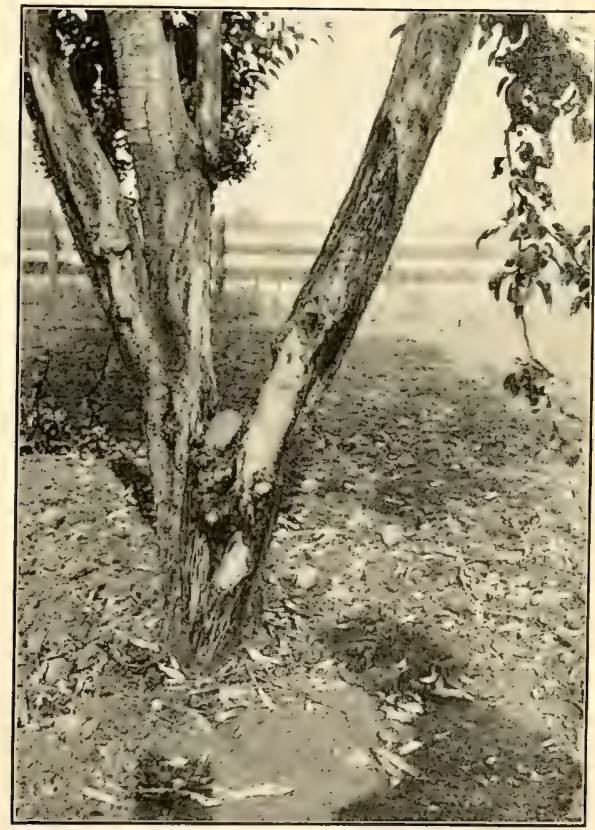

Figure 4-Body infection of Bartlett, due to water sprouts, First attempt to eradi cate the blight unsuccessiul, and it was necessary to peel the bark and sambium at a greater distance. (Photograph by the author). 

The treatment for pear blight, or rather the methods for controlling it, may be divided into two classes, primary and secondary. The primary method of treating this disease consists of cutting out thoroughly and antiseptically the hold-over blight during the dormant season of the trees-that is, during the fall and winter. It has been explained that the hold-over blight may be found in the larger limbs, the trunk and even the root system. These hold-over cases have become such through the various means of infection pointed out in a previous chapter, namely, through blossoms, buds or water sprouts, which have become infected and through which the blight has gained entrance to the fleshy bark and cambium of the bodies and roots. The other methods of entrance, as pointed out before, are through growth cracks, crown galls, insect and bird punctures, or any other way by which the epidermis may be broken so as to expose the tissues beneath. It has also been shown that the pruning knife or other orchard instruments and implements may be the means of spreading the disease. If the work of removing hold-over cases is done thoroughly it leaves no opportunity for additional advantages from any other secondary method to be given later.

Remember that the important thing is the removal of the source, or what will be the source of infection the following year. In the case of the pear or apple it is important that this work be done as skillfully as the work of a surgeon in removing a member infected with blood poison. Everyone realizes the attention given to the source of al city's water supply, and it may be said that the death rate is very largely an index to its condition. In the same sense; the attention given the sanitary conditions of the orchards of any community is an index of the death rate of the orchards. Of course, the cutting out of hold-over blight must be done, not alone in a single orchard, but the work should be general and thorough throughout the entire area, such as an inclosed valley or even, for better work, an entire state. Complete eradication of pear blight from such a large area is, of course, very difficult, but not impossible. However, the fewer hold-over cases that may be missed 
will result in fewer cases of infection later in the spring and summer. As may be seen by referring to the factors influencing the disease, the presence of the germ is of primary importance. If the pear blight germ is not present in the orchard there can be no blight, no matter what the weather conditions may be. The orchards of California existed for twenty-five years with varying climatic conditions, and no one ever heard of blight in those orchards until the germ was introduced.

The regular development of the disease has been pointed out by which it runs down on one side of the limb or body and not on the other; this often leads to failures in eradicating the blight from orchards. While the disease in the top is very easy to handle and anyone who looks at all closely cannot only detect it, but can readily remove the infected branches; the disease on the bodies and in the root system is not only hard to see, but it is often difficult to find it, especially on old trees where the crowns and bodies are covered with rough bark. It may be said here that the removal and the detection of hold-over in pear trees is not nearly so difficult as is the case in the apple and the quince. The Spitzenberg apple is probably the worst variety, if not the worst species of the pome family, in which to detect hold-over and to effectively remove it.

The gum exudate, when it is present, gives a clue to many otherwise obscure cases. However, in cases of late fall and summer infections, the lesions may be so small as to produce no exudate or give any other evidence of infection. A dead water sprout or fruit spur, no matter how tiny it may be, leads to the detection of a case. Sometimes these have been broken off in cultivation or carelessly cut off without following up the infection at the base. Very often a water sprout which has come up from the root system at some distance from the base of the tree, becomes infected, and is later removed by cultivation; but the infection passes on up the infected root, finally involving the entire root system. Sometimes there is infection without a water sprout or bud at all, and such cases are the hardest to detect unless some ooze has exuded. Such infections come about through insect punctures and 
growth cracks by means of which the germ has been introduced. Where there is a large amount of blight to be removed from the orchard, necessitating a great deal of labor, it has proven necessary in every case to go over the orchard critically, or perhaps we may say leisurely, on a dry, sunshiny day when there is good light, and find the few cases that have been missed on the first inspection. No matter how thorough the work, this careful method of inspection has proved extremely important. Not only should the work be inspected immediately following the general clean-up, but someone else with keen, well-trained eyes should look over the trees several times during the winter. A special effort should be made to find out when there is a new exudation of ooze. This may follow any warm, mild spell in the winter, when there is a wide range between the day and night temperature. Such conditions are known to affect the flow of sap in the sugar maple and other trees. A final inspection should be made just before blossoming time to catch any hold-over blight the last moment, in case it has been overlooked before.

After the blossoming period has passed so that the blight has had time to develop, if a colony of blight is found in the orchard, careful examination of this colony will generally result in the finding of a case of hold-over blight in the center and from which all trouble may be traced. During the first year's work, those who are just learning how to eradicate blight will probably miss a good many cases; however, after practice, they usually become keener and rarely miss any. In fact, I have seen men who from the very first were able to do excellent work, but, like other jobs which require careful work and a sharp eye, relatively few men are capable of making first-class inspectors. In many of the large orchards where the question of efficient labor is serious and where all sorts of tramp and other low-class labor has been employed, absolute failures in blight control have generally resulted. As I have stated before, a tramp, or, for that matter, even the better sort of laborer, cannot be thoroughly schooled in careful work of this kind within the space of a day or two. In every event, the best and most careful men should be 
placed in charge of work of this kind. It is almost needless to say that the breaking up of the larger tracts into smaller ones of, say, five or ten acres, will largely solve the problem of blight control. When this is done each tract will have close, personal supervision, and the details of eradicating the blight, as well as keeping it under control, will fall to the owner. It is a common mistake to think that the matter of eradication and control rests with the inspector alone. An inspector must have the co-operation of the entire district. I do not know of any one who would ask an inspector to assume the matter of cultivation, pruning or any other of the regular orchard practices; so why should an inspector be asked to do the actual work of blight eradication? The inspector is, in the first place, an instructor, and in the second place, the one to enforce the horticultural laws, but he is no common hired man.

It must be understood from the very beginning that there is no spray-cure or remedy for blight. Being a bacterial disease, and once the germ has gained entrance to the bark tissues and the cambium layer by any means whatever, it can readily be seen that any external application in the way of a spray or wash could not be effective. There is but one thing to do after infection has started, and that is to remove, by cutting, the affected parts. In other words, the operation is purely surgical. In all of the cutting a strong disinfectant should be used to wipe off the tools after cutting into the blight as well as to wash off the wounds made by the instruments; otherwise, it is possible to introduce the germ into the cut surface and to carry it from tree to tree on the pruning tools. In the majority of cases, in dry weather, infection would not result from the use of pruning tools, even though they were not disinfected, but it is never a wise plan to take a chance. In the late summer or early fall, when the exhuberant growing season is over, the chances for infection by the use of unclean tools are not so great; however, it has been determined by numerous experiments that blight punctured into the fresh bark in the fall may remain semidorman through the winter and may result in a fine case of hold-over blight the following spring. In working out 
blight as much care should be used to prevent accidental inoculation and infection as a surgeon would use in performing a major operation.

For disinfecting the cut surfaces and the instruments, the best thing to use is a solution of corrosive sublimate, or bichloride of mercury, in water, one part to one thousand. It is often advisable to use the disinfectant a little stronger, and there is no danger in using one to five hundred. Tablets may be obtained from any drug store, and the number to be used to produce any strength of solution is usually indicated upon the bottle. To be sure that no mistake is made, ask the druggist how many tablets to use to produce a solution of desired strength. When possible, use rain water, as the slightly alkaline waters in dry countries tend to precipitate the poisonous mercurial compound. Also use a glass or non-metallic container, as a tin can or other metal container may react on the disinfectant, and remove the poisonous principle. Corrosive sublimate kills the pear blight germ in solutions in water when it is diluted to one part to 10,000 , therefore, the above formulæ are sufficiently strong and well within the limits. While there are other disinfectants that may be used, bichloride of mercury is by far the cheapest, and there is nothing gained by using anything else. The use of kerosene, gasoline, and such like, is certainly not permissible. Even carbolic acid is distinctly inferior to corrosive sublimate and, besides, its noxious smell and burning tendency do not warrant its use. It must be remembered, however, that corrosive sublimate is a deadly poison when taken internally, and the bottle or container should be plainly marked poison. Applied externally to wounds, or upon the hands, it will cause no injury, but, on the other hand, will as readily disinfect as in the case of the tools and cut limbs. The greatest care should be taken in emptying the bottles containing the solution when returning to the house, or otherwise keeping both the bottle and solution away from children or unsuspecting persons. As indicated before, there is no danger in getting the solution on the hands; in fact, a cut or wound should be treated with it to prevent bacterial infection which might 
result in blood poisoning. It should be understood, however, that the bacteria of pear blight are not pathogenic to man; that is to say, the germ can produce no evil effects even if introduced into the human system. It is a good plan to use a sponge, which, if fastened by a string about two feet in length and tied to one's clothing, is always handy when it is necessary to wipe the pruning tools and the cut surfaces of trees. Some operators tie a sponge by a very short string to the wrist, and this is probably the most convenient way to use it. An inch or three-quarters-inch carpenter's gouge is also an excellent tool in the makeup of a worker's outfit. With it a small chip may be taken out of the rough bark in inspecting large trees, and besides, it is a very handy tool in working the blight out of difficult places where ordinary tools cannot be so easily used. In inspecting large trees, whether apple or pear, the gouge must be used to examine the bodies and the crowns. Unless this is done, cases of hold-over will certainly be missed. In large, rough-barked trees, a chip should be taken out at intervals of about two inches all around the crown, as well as higher up on the body. It is not necessary to go below the outer layer of soft bark tissue, and it is quite unnecessary to cut as far as the wood. When the chip is taken out, if the bark tissue presents a water-soaked appearance, or if it is of a red or perhaps bright red color, it is almost certain that the body is infected. When a point of infection is found, it should be followed up so as to determine the extent to which the infection has run. If careful work of this kind is done, no hold-over will escape detection.

It is a good plan, when ignorant pruners are in the orchard, to make them disinfect in the general pruning. As a rule, I would suggest that eradication of blight precede the general pruning. A special set of skilled help should do this work and then the ordinary pruner may follow. Even in ordinary pruning it is a safe plan to disinfect when leaving each tree in order to avoid carrying the disease in case the pruner has cut into an overlooked case of the blight. There is a question as to what to do when the blight is found running down the bodies and into the roots 
of trees. Where the disease occurs on limbs it can be readily sawed off, as the removal of even the greater portion of the twigs and the branches by no means entirely destroys the value of the tree. The tree will push its new top vigorously, and in two or three years be in full bearing again. Where the blight has run past the main forks, however, a serious question is involved. Where inefficient, unskilled labor has to be used and where there is but little blight to work out, we advise pulling out all trees where it has run down the bodies, or has infected the root system. Many growers, when the matter is explained to them, condemn such trees and root them out, and thus, of course, simplify the matter. On the other hand, it is possible to effect an eradication of the blight by carefully cutting out the bark, and even the discolored wood, entirely beyond the limits of the infection. An inch or two at the side, and three to six inches at the bottom and top of the infection, may be regarded as safe if done during the winter. However, such cutting will not do during the spring or summer when the sap is flowing rapidly. Such work invariably results in missing many cases. It is never a good plan to leave the matter of working out hold-over blight until after the sap begins to flow; the best time to do this, and do it successfully, is during the dormant period. However, I do not mean to say that hold-over may not be removed at any time, but I do mean to say the chances for successful operation are very much less, and the amount of cutting necessary is always much greater and more destructive to the appearance and health of the tree. As a general principle, we believe in drawing the line on those cases where the blight has gone below the crown and into the root system. Even here, however, it is possible to dig away the soil and follow up the blight on the roots. A tree should never be considered as wholly lost where skilled labor may be had, and where the body is not completely girdled or where the root system is not too badly involved. Where a large portion of the bark must be removed from the body, leaving only a small portion to carry sap, bridge grafting may be resorted to to fill in the part cut away. If this is well done, and if the bared 
wood has been protected by a white lead paint, a new bark covering may be grown. This has been done in a very successful way in several instances. In case a tree has set a heavy crop of buds for the next year, this plan will evenutally help to carry the fruit crop.

In case a part of the root system, as well as the bark and cambium above, must be removed, the parts removed may be eventually filled in by planting good young trees from the nursery row, setting the roots well down and grafting them into the healthy tissues above. These trees will tend to grow together and finally fill up the portion cut away. Care must be taken, however, that the thrifty sprouts from these young trees do not become affected with blight.

Summer cutting intelligently applied may do a great deal of good in saving trees which would otherwise be lost. This is especially advisable where there is only a little blight in the orchard (by this I mean to say that unless the infection is so serious as to necessitate the destruction of the entire tree) and it should always be practiced. The dry summer weather of most of the Pacific coast country, especially from southern Oregon southward, is certainly not favorable for new infections, but occasionally spring rains occur rather late, and sometimes extend into the summer and after the blossoming time. Until the present year such has not occurred in southern Oregon, but the past spring has had several infection periods in which conditions have been extremely favorable to the development and spread of the disease. Under eastern conditions, or where excessive spring and summer rains are the rule, summer cutting is only half successful, and has, therefore, been condemned by most pear and apple orchardists as a failure. Summer cutting is a failure, or is made apparently so by the fact that new infections, invisible at the time the work is done, may develop in a few days so that a week after the most thorough cutting out of the blight a new crop of infection is found thriving. Another source of difficulty in the spring or summer time arises from the rapid extension of the blight infection in the branches of varieties that are very susceptible to the 



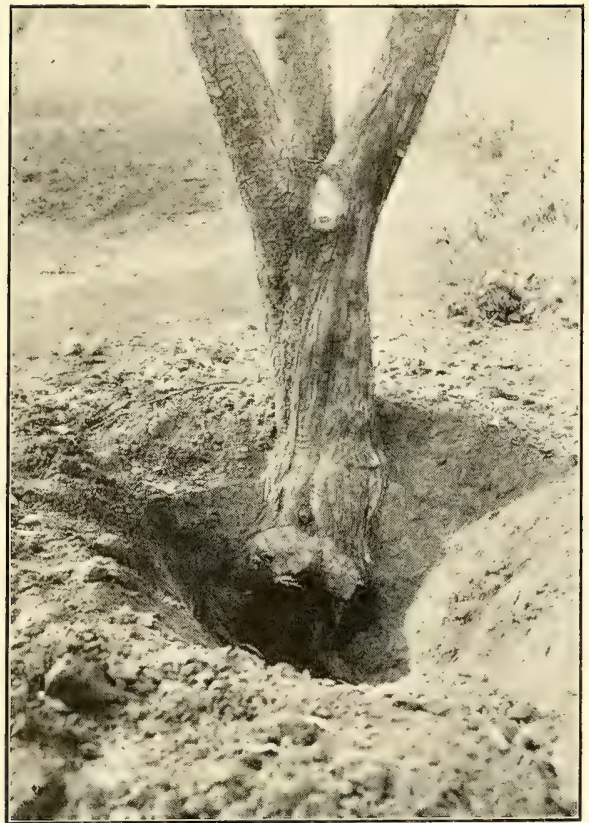

Figure 1-Bartlett pear tree showing the blight eradicated from the body. It was necessary to cut part of the root system away. This tree is capable of bearing a normal crop. (Original photoeraph by the author).

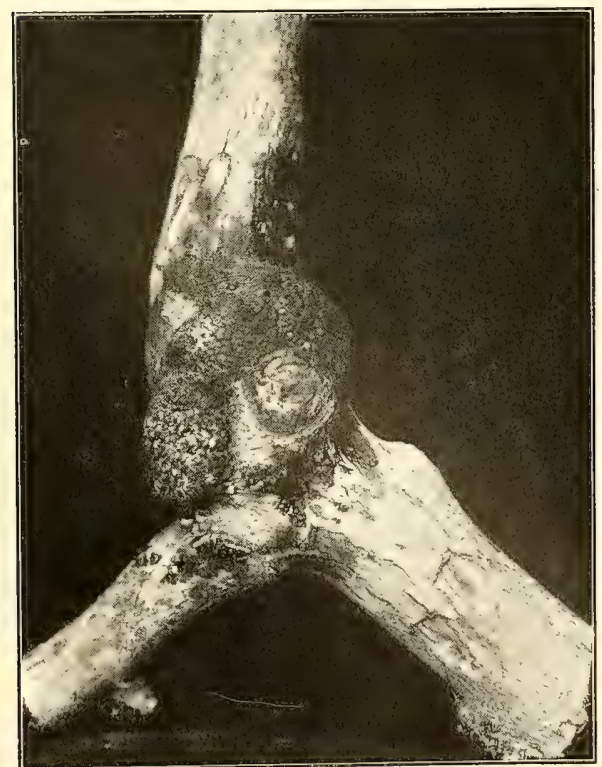

Figure 3-Crown arall on branch of Spitzenberg apple, showing pear blight infection. Note the ooze coming out both sides of the crown gall. (Original photograph by the author).

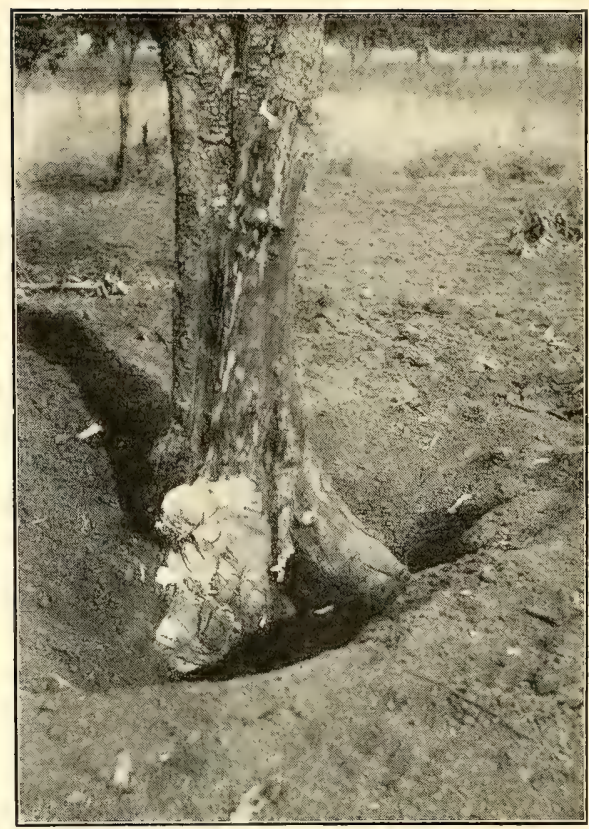

Figure 2-A bad infection of the body and root system. Only a small part of the root system left. The tree will $c m$ tinue to bear fruit. (Photograph by the author).

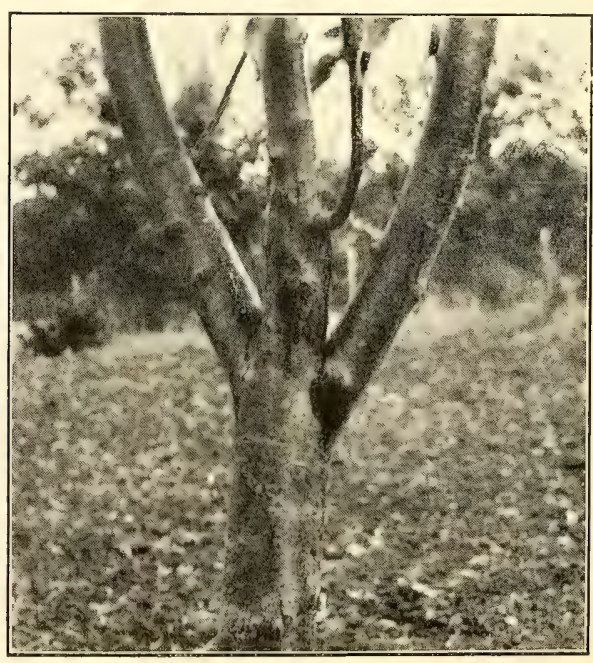

Figure 4-Spitzenberm infected with pear blight. Note the two streams of ooze running down the body. (Original photograph by the author). 
disease. Sometimes, especially where the infection has reached a large leader or the body, the germs often reach a foot or two beyond the discoloration, as the disease is spreading so rapidly that the bark has not had time to discolor sufficiently to be detected; therefore, in summer cutting the removal of the infection must be at a greater distance from the point of infection than in fall and winter work. Experienced men can judge somewhat of the distance by the rapidity with which the stained bark blends off into the normal bark. Furthermore, a reddish streak will often be apparent in the cambium and young wood, and by following it up, a clue may be had as to the possible trend of the blight. The greater the distance in which the blending take place the lower the cut must be made, and conversely. Disinfection is more important in summer cutting than in winter cutting, and, although in the dry coast climate the sunlight and dry atmosphere will usually take care of most of the germs accidentally left on cu surfaces, it is by no means true that infection may not take place from such cases. Furthermore, a foggy morning following the cutting might spoil the whole procedure, so the only safe way is to always disinfect. In a recent bulletin published by one of the eastern agricultural colleges the recommendation is made to "disinfect the cut or wound and not the tools." This is one of the worst mistakes that could be made, and shows that the author has never had any practical experience in fighting the disease. Often in using the tools, accidental cuts or punctures are made, and it may happen that infection may be produced by them. As to the choice of a disinfectant, permit me to state once more that there is nothing cheaper nor better than bichloride of mercury, and any substitute for it should not be considered. Always use the proper strength, one to 1,000 , or even stronger, and accept no substitutes. Do the work of summer cutting of blight with as great care as possible; if this is not done you may reasonably expect to do it all over again, and perhaps lose some very valuable trees.

I notice in a bulletin published by the Oregon Agricultural College the following statement: "Experience has 
shown that it is of little permanent value to cut out the fruit spurs and twig blight as they appear." This statement is merely qualified by saying that "Unless these forms of the disease extend into the branches on which they occur, and a canker is formed, the disease naturally becomes limited and the germs gradually die, due to drying out of the canker, so that at the beginning of the dormant season very few such cases show live germs present." The above statements do not seem to indicate a knowledge of varietal susceptibility nor the effect or influence of climatic conditions. It would seem to indicate merely a study of conditions such as we would find in parts of New York, along the great lakes, and in the New England states generally. On the Pacific coast conditions are entirely different. In my experience on the Pacific coast, such varieties as the Spitzenberg apple, the Bartlett, Howell, Easter, Bosc and Comice pears are very susceptible, and at no time should one disregard the removal of a fruit spur or twig which is found to be infected with blight. During the past four or five years on the Pacific coast, it has been my experience that thousands of trees have been saved by the prompt removal of infected twigs and fruit spurs.

I also note in a bulletin published by Cornell University, which is probably responsible for statements made by the author of the Oregon Agricultural College buletin, the following: "Break out all blossom spurs that show the disease and remove them from the orchard. **** The removal of these spurs as soon as they show the disease will prevent the bacteria from getting into the limbs." This advice is almost as absurd as that of not removing them at all. Never remove an infected spur by breaking it off. First find the limits of the infection and then remove the spur with a knife. I have in mind a particular case in which the advice "to break off the infected spurs" nearly ruined an orchard. It is really too bad that we are compelled to speak so plainly in this matter, but in our work we have had to contend with growers who take every opportunity to avoid doing efficient work, especially so when guided by statements published and sent out from sources supposed to be reliable and authentic. 
By far the greater part, probably as high as 80 per cent, of the loss of pear trees in California and southern Oregon has resulted from body and limb infections through water sprouts and low fruit spurs. Water sprouts coming up from the root system, even at some distance from the base of the tree, have caused fatal infections. Fruit spurs, when located on the body or main forks, and becoming infected, soon introduce the germs into the thick, fleshy bark, which carries much of the sap, and destruction is very rapid if the tree is growing rapidly and if it happens to be a very susceptible variety. Water sprouts from the French stocks on which the majority of our commercial varieties are grafted are very susceptible, and should be removed with the greatest care. It needs no argument therefore, to state that the removal of water sprouts and fruit spurs well up on the limbs is an important subsidary practice in the control of pear blight. Much of the cutting of water sprouts is done by farm hands, who remove them so as to leave a stub an inch or so long. The result is that several water sprouts come from the same place the next year. Water sprouts should always be cut out as far in as the wood, and a gouge or sharp saw, although producing a larger cut surface, effectually removes the spur for all time. Heavy pruning back of the tops of the trees, as generally practiced throughout the coast as a means to secure heavy fruit yields, encourages the pushing of these water sprouts so that the problem is really an important one.

Crown galls, which may be found on any part of the root system or the body and branches of a tree, should always be removed when found. The Spitzenberg is very susceptible to crown gall, and it is not infrequent to find numerous galls on the body and limbs. The peculiar nature of these crown galls is such that pear blight germs find a ready entrance. During the past season I have seen hundreds of infections which entered the trees through crown galls. In cutting away crown galls, which in themselves are caused by a bacterial organism, the bark and cambium should be peeled away at least an inch from the edge of the gall, and the gall itself completely cut out with a 
chisel or gouge. Then thoroughly sterilize the exposed surface. The reason for going well beyond the outer margin of the gall in removing it, is because we find the organisms causing the crown gall in greatest numbers along this margin.

One matter of very great importance, and which has been mentioned before, is the possibility of working all the non-resistant varieties of pears and apples on resistant stocks or bodies. It has been stated that the Winter Nelis and the Kieffer varieties of pears are the most resistant of commercial varieties. Under eastern and southern conditions, the Kieffer pear is really the only one that has stood against the ravages of the blight. By this $I$ do not mean to say that it is wholly immune, because under extreme conditions it will blight. However, the conditions on the Pacific coast are such that if the Kieffer were used as a stock or body there would be little danger of losirg the tree by root and body infections. Experience in California has shown that while Bartlett and other non-resistant varieties have blighted as far as the Nelis and Kieffer stocks, the infections have usually stopped at the graft union. Every pear grower on the coast who has had experience with blight knows that Winter Nelis and Kieffer, the latter being very rarely grown, seldom blight seriously, although they may be surrounded by a great deal of infection. Of course, we do know, on the cther hand, that they are not immune even on the coast. I could offer as a suggestion that Kieffer stocks might well be set out and afterwards top-grafted to any of the commercial varieties of pears. This will, at least, provide resistant bodies and roots which will eliminate the danger of loss by body and root infection. I wish to urge that the finding of a variety of pear entirely immune from pear blignt will alone solve the pear blight problem for this species of pome fruit. The same will be true of any other of the pome fruits. As soon as an immune is founc, the possibilities of plant breeding will, no doubt, evolve commercial varieties equal to those that we have now, and at the same time they will be immune from disease. This is looking far into the future, but it will be done as it has been done with other plants. 
Some remarkable cases of eradication have been attempted and successfully accomplished in California and Oregon orchards, notably in the vicinity of Vacaville, California, and in the upper Rogue River valley in Oregon. In some cases where perhaps fifty per cent of the trees were infected on the bodies and in the roots, but still had sufficient living bark and a few roots left, the diseased portions were completely cut out, even to the removal of all the roots on one side of the tree and peeling fully three-fourths of the bark from the body. I have noted in some instances where fully three dollars in labor was expended in removing the blight from a single tree. This, of course, is exceptional, but where the value of the tree may be placed at from ten to fifty dollars, depending on its ability to bear heavy crops of fruit, this would not seem to be an undue expenditure in eradicating the blight and saving the tree. Many of the trees so treated have not lost their vigor and are still bearing good crops of fruit. From our standpoint, as pathologists, if pear blight is completely removed under antiseptic methods from the body and roots, the job is satisfactory. It remains, therefore, with the grower to decide how much labor he is going to undertake to save the tree. Experience throughout the east and south has been that where much work of this sort has been attempted on the bodies, numerous failures have resulted, and the work rendered worse than useless. There is also more or less danger, in such cases, of the blight in the sap wood. While the germ almost wholly lives in the bark and cambium, it is also known that it may infect the rich sap wood of the Bartlett, Howell, and other varieties of pears. This is also true of the Spitzenberg apple. Occasionally it has been noted that the germs spread out in the vessels of the wood and live on the starch and sugar stored there. It is, therefore, desirable to leave all eradication work on the bodies dry out thoroughly for perhaps a month or so before painting over the wound with white lead paint. If any growth takes place the ooze may be detected by the discoloration appearing on the paint. It is certain that a great deal of blight eradication work may be done to the best advantage in the 
early autumn, for certainly better results may be obtained before the fall rains begin. It is also much easier to detect the blight which has attacked the branches and twigs during the summer, because at this time the foliage generally shows where the blight has been working. Besides, trees that have the roots infected generally begin to show a reddish discoloration in the foliage. A bad body or limb infection will also have a tendency to cause the same discoloration in the foliage above the infected part. However, this reddish discoloration of the foliage is, by no means, a certain indication of blight infection, as there are many other causes which would produce a like appearance in the foliage. Root rot, borers, gophers, or even a girdle caused by any means whatever, will produce practically the same discoloration. In irrigated orchards where the water has been cut off too early in the summer, there is always a tendency toward foliage discoloration. The foliage test, however, is a sure one that something is wrong with the tree, and such a tree should never be passed by without making a very critical examination. Never leave a tree unless you are absolutely sure of your work. Careless inspection and careless eradication are really worse than no work at all, for, on the one hand, enough work may be done to deceive, while on the other hand the chances for infection and subsequent spread of the disease remains.

Spraying, as a rule, is of little use in controlling the blight. In the blooming season new blossoms are opening every hour of the day, and new shoots are pushing forth, all of which are subject to infection through insect agencies. From the standpoint, therefore, of attacking the pear blight problem by spraying there is nothing to be done so far as the blossoms and young shoots are concerned. On the other hand, we have been able to cover up some mild cases by whitewash, applied thickly, so that they were unable, temporarily, to be a source of infection during the blossoming season. Whitewashing or spraying in the winter time may be of some slight assistance in the matter, but it is not recommended. A strong lime-sulphur wash applied to the bodies just before the blossoms open will have a tendency to keep insects away from any infec- 
tion which would ooze. It must be understood, however, that all pear blight infection should be carefully removed, ard in no case should there be any attempt to cover up any known case of hold-over blight. The only reason for advocating the strong lime-sulphur wash is that, should a case be missed by accident, the use of the wash may prevent the infection from getting away. Just as soon as it is discovered, whether the wash has been applied or not, it should be removed. I wish to emphasize that any attempt to spray or wash may be considered only a temporary make-shift. If there is a case of hold-over that has been covered by spray or wash, it must be eventually removed, and especially so if it is in the body of the tree. The wash in no way controls the spread of the blight in the soft bark beneath, its only office is to prevent, if possible, the spread of blight to other trees, by preventing insects from coming into contact with the bacterial ooze.

There are on the market a number of so-called remedies for pear blight. All the concerns selling these remedies have no standing whatever, and ther literautre, which is sent broadcast over the country, may well be promptly thrown in the fire. A favorite remedy is a mixture of potassium cyanide and sulphur placed about the roots of the tree. Still others consist of such insolubles as charcoal, calomel, sulphur, bone black, and other substances put into holes bored into the bodies of the trees. In every community trees may be found that have been treated in this way, and invariably the materials put into the holes has neither changed its chemical makeup nor has it diminished in quantity by absorption.

A common remedy is the use of table salt, or even some alkali, both of which would be promptly removed from the soil if present in too large quantities in nature. The use of table salt is merely to inhibit the growth of the tree by preventing the normal taking up of water by the root system. A tree grown in a very saline soil cannot take up water enough to make a strong growth, hence, it does not blight badly, perhaps not at all. As indicated before, trees grown under good cultivation with sufficient moisture and plant food make a strong growth, and are, there- 
fore, more subject to blight. There should be no desire on the part of an orchardist to injure his soil, and consequently, his trees, by adding to the soil any chemical or salt known to have a poisonous action, or at lest, an inhibitive effect. Do not take the word of everyone or anyone who has something to sell. Before buying any cure or remedy, consult someone who can be trusted and who has nothing for sale.

The whole subject of pruning is such a lengthy one that it can scarcely be gone into in full detail. However, the vase-formed tree, headed low with the main branches shortened in to eighteen inches or less, is decidedly the. most desirable form to grow a tree. Up to the third year the main forks or leaders should be so shortened in so as to make a tree with a sturdy framework and at the same time keep it down so low as to be accessible for spraying, picking fruit, etc. If water sprouts are kept off the body and main limbs, and if lateral fruit branches are developed within the fruiting area, the most desirable form of tree will be produced for controlling the blight. A tree pruned to this form, even if infected, has its blossoms well away from the vulnerable parts of the tree, namely, the body and framework. The tall pyramid, with a single main leader and with its long branches covered with fruit spurs and water sprouts, makes the work of fighting pear blight a difficult one. It is hard to get into the top of the tree with this closed center to find out what is going on, and, besides, the fruit spurs and water sprouts being close to the body as well as upon it, readily carry the blight in, usually resulting in the entire loss of the main portion, if not the entire tree. One only need look around the valley where the pyramidal or central leader type is grown, and it will be seen that an infection on the body resulting in a girdling of it necessitates the removal of the entire center above the point of infection, thus removing practically all the heart of the tree's growth. Any of the limbs left below the point of infection are usually long and slender, and, besides, are usually poorly placed to form a rood tree of any sort thereafter. The pravailing type of Bartlett tree in California is very near the desirable form; 
however, in many cases, after heading back the trees, they have been allowed to grow three or four years and then reheaded several feet from the crown, sometimes as high as fifteen feet, resulting in a two-story pear tree. In very few cases has there been any attempt to keep the fruit off the main framework branches, and to keep the water sprouts and fruit spurs from the bodies and roots. There has been no special occasion for forking at the framework, since at the time the trees were being formed pear blight had not made its entrance into the California orchards. Among many growers, especially those of the old school, in the Rogue River valley, we find that there is a tendency to adhere to the pyramid form of tree in practically all varieties grown, even the Bartlett. We readily understand why this has been the case, because the pioneer fruit growers in the valley recognized only this form of tree as being, perhaps the easiest to prune and undoubtedly the easiest to keep from breaking down when heavily loaded with fruit. Their weak attempts at forming the open-headed tree were failures because during the first two or three years of growth they neglected to shorten in enough. Even today this is the common error; it would be better to shorten to six inches than to lengthen to eighteen inches. Now that pear blight has come into the valley, this method of pruning, or forming the tree by maintaining a central leader, will have to be altered. I know of perhaps five or six hundred trees that have been wholly lost on account of this style of growth; that is to say, practically the entire bearing portion of the trees had to be taken out on account of blight girdling the leader. In many young orchards which have been planted within the past two or three years, the growers are changing them into the vase or open-head form, recognizing the great difficulty in saving the other type of tree should blight become serious. In the larger trees it is a rather difficult thing to change them over into the vase form, but in every case where blight has seriously damaged such trees the resultant tree, of necessity, becomes vase formed when the blight is cut out.

Severe pruning, though in most cases, of course, giving 
good results in stimulating vigorous twig growth and fruit production, tends also to result in more serious attacks of the blight. Everyone knows that the more vigorous the winter pruning the more luxuriant the twig growth during the following season. The result always is that every dormant bud tends to push, and, being very tender and sappy, easily becomes infected and blights badly. On the other hand, as soon as the trees come into bearing, summer pruning, if practiced in the proper way, will result in a more normal vegetative condition, and the tendency to set fruit will also be correspondingly greater. A heavy set of fruit, other factors being equal, will always tend to keep down excessive vigor; and this is usually a good thing under Pacific coast conditions, where the growing season is quite long as compared with conditions in the eastern sections of the United States.

Cultivation, fertilization and irrigation are three very important factors to be considered in connection with the control of pear blight. I shall take these up separately, with only as much detail as will make the text plain. Thorough cultivation is more essential, especially from southern Oregon southward on the Pacific coast, than in the east, for the reason that rainfall is not only much less, but from the spring of the year until autumn the season is practically without precipitation. In districts where irrigation is practiced, cultivation is just as necessary. In the east it is not an uncommon practice to permit pear and apple orchards to grow in sod when it is evident that the blight is getting beyond control. Everyone knows that lack of cultivation induces surface evaporation from the soil, and trees are thus made to grow more slowly because of lack of moisture, and hence, even very susceptible varieties of pears and apples do not blight badly because the vegetative vigor is lacking. The necessity for cultivation as well as the method to be used varies so greatly in the pacific coast orchards that it is impossible to make any general rule. Each soil type requires different treatment to the end that soil moisture be retained during the growing season of the trees. Some of the moist, deep soils in the Sacramento river districts, and perhaps in a few 
spots in the Rogue River valley, retain their moisture so well that pears get along very well for a year or so without cultivation. On the other hand, practically all of the lands in these districts need thorough cultivation to bring them up to anything like normal and to mature full crops.

The matter of fertilization is an important one, especially where large crops have been taken for several successive years from an orchard. However, it is known that nitrogenous fertilizers, such as stable manure, as well as commercial fertilizers containing large amounts of readily available nitrates, tend to produce luxuriant growth, and hence, trees so stimulated blight more seriously than those not fertilized. Fertilizer must be used, but it must be used in moderate amounts. There is no advantge in using an excess of potash to make the trees more hardy and thus more resistant to blight. The fondest hopes of some would-be experimenter have been blasted by trying to prevent blight injury through the use of potash in the form of muriate and sulphate. It is the same old story, the blight must be controlled by having no hold-overs present during the infection period. I have seen large commercial orchards practically ruined in one year where potash was used as a preventive against blight, so avoid using it for any other purpose than adding fertility to the soil.

The whole subject of irrigation is so broad that it will only be discussed here in its connection with the control and eradication of pear blight. While irrigation cannot be considered in the same light as rainfall, since it is merely water applied to the root system, it is, nevertheless, important to understand it thoroughly, especially in connection with blight control. It has been pointed out that periods of rainy weather during the spring and summer produce what have been termed infection periods, through the wetting of the trees, and thus permitting a spread of the infection through infected trees, and making it possible for the germs to be more readily distributed over a considerable area in any district. The warm, muggy weather, such as we find common in the east following rainy periods, further tend to influence the spread of infection. Irrigation in no way induces any of the above 
conditions, but, on the other hand, its effect is noted in the tendency of the trees to push very rapidly under a normal water supply and to become sappy and less resistant to blight. It is well, therefore, to have this in mind, and to apply no more water than is actually necessary for the production of the crop or the maintaining of a healthy condition in the tree. In cases where serious infection has made itself apparent, the water should be immediately turned off and kept off until the blight is under control.

It is safe to say that in all irrigated districts some harm usually results from over-irrigation rather than under-irrigation. The tendency to apply too much water is especially the great fault with beginners in irrigation. To irrigate properly and scientifically, one should know soil conditions, soil depths, and drainage. Another important factor is a knowledge of the duty of water; by this it is to be understood the amount of water which should be used to produce the best results. The Rogue River Valley is so situated that a minimum amount of irrigation should be used in certain well-defined districts, or, perhaps I might say, very small areas. Generally, pears can be grown without any irrigation whatever; and with good cultivation and proper soil treatment, apples will be able to get along fairly well with much less water than is generally supposed. It is well known that the destruction of pears by blight in the San Joaquin Valley, in California, was due as much to maintaining too vigorous a growth by irrigation as it was through lack of the important detail knowledge of fighting it scientifically. Not only were the orchards lost, but valuable soils were practically ruined by overirrigation.

It is a well-settled fact that irrigation is to be practiced more or less generally in the Rogue River Valley, but I wish to sound this note of warning in regard to the matter of over-doing it. It is doubtful if the heavy, black, sticky soils of the valley floor are at all benefitted by irrigation; I might say that it has been proven that they may be injured.

In the Eastern states it is a very common practice to sow a crop of cow peas, sorghum, or sometimes even Indian 
corn in the late spring. This is done to take up the surplus moisture of the soil from the trees, and has a tendency to check luxuriant growth, and hence acts as a check to pear blight. It must be understood, however, that the above practice would not be at all advisable in most Pacific Coast districts, where there is a shortage of soil moisture. There are localities, however, where it may on some occasions become necessary to make use of cover crops in this way. The use of cover crops on the Pacific Coast should be for a wholly different purpose; namely, to add fertility to the soil as well as to change its physical condition; in fact, the use of cover crops may be considered to serve the same purpose as stable manure in making the soil more easily tilled and rendering it in better condition for giving up plant food. Cover crops of vetch or cow peas, of course, add nitrogen to the soil, and, from this standpoint, it is perhaps better that these leguminous plants should be used in preference to rye, or any of the grains or grasses. On some soils such cover crops as rye or wheat do not give the best results, especially on the sticky soils. It usually takes a great deal of labor to produce a good soil mulch after turning under a crop of rye.

The rule in the pear orchards of the Eastern states has been to keep the trees in a half-starved condition for fear blight would destroy them. Orchard treatment of this kind naturally renders the fruit less luscious and with a distinctly poorer flavor than fruit grown under good cultivation. While I would advise a good deal of caution in producing too vigorous or sappy a tree, where there is serious danger of destruction by blight, I would not advise the pear and apple growers of the Pacific Coast to starve or under-cultivate or under-prune their trees; but I do mean to say that they should practice moderation in all these things. This is especially true in districts where the blight is new to them, and where they are not thoroughly acquainted with the methods of eradicating it from their orchards and keeping it under control. Pear blight is so different from all other orchard diseases, which respond so readily to spray treatments, that it has been the general rule for whole communities, and even states, to lose all 
their orchards before being brought to a realization of the necessity for studying the disease carefully and obeying to the letter the instructions for combating it.

In a preceding chapter, mention was made of the enormous losses in the pear districts of the San Joaquin valley, California. In the short space of three years, from 1900 to 1904, almost half a million pear trees were lost by blight. Practically no attempt was made to check the disease, and one of the greatest industries of the San Joaquin Valley vanished like a dream, and even before the people realized what had befallen them. As in other localities, East and South, the growers had a self-sufficient and self-satified feeling that blight could never hurt them. They had grown pears for a quarter of a century and more, and such a thing as blight entering their valley was just as impossible as anything one might imagine.

In all that time, thunder, lightning, excessive heat, cold, etc., had caused not the slightest injury. However, as soon as blight came, all the factors mentioned above seemed to explain their predicament fully; they needed no help and spurned assistance. This is the story, in a few words, a story which might be told of many other localities which had suffered the same calamity.

In 1904 the blight invaded the pear district of the Sacramento Valley, and although some little work was done in the matter of eradicating it, the efforts were weak and ineffective. Prominent men in the state became alarmed, and the pathologists of the United States Department were called to the Coast. In the fall of 1904 Professor M. B. Waite made his first visit to California, and inaugurated a plan of campaign for eradicating it, or at least keeping it under control. I may say that the Government pathologists did not come to the Pacific Coast until they were called. Such influential men as Ex-Governor Pardee and prominent Southern Pacific officials appealed to Hon. James Wilson, Secretary of Agriculture, to send as many men as he had available, to aid in what was thought to be almost a hopeless case. Blight was everywhere, with the exception of the Santa Clara Valley, which to this day has kept it out by very careful and hard work. The task under- 
taken was an enormous one, and the amount of territory necessary to be covered was so large that every available source of help was called for, and the campaign finally started in the early winter of 1905 . The time was short, but good work was done. In many districts where there was a willingness to co-operate with the Government officers the blight was checked; in others, where conditions were the reverse, the blight gained headway. The result of several year's work, which has been carried on up to the present time by the United States Department of Agriculture, is that several districts in the Sacramento Valley and adjacent valleys, have saved their pears. There are particular instances where practically everything went excepting single orchards which were saved by indıvidual growers, by using heroic measures and carrying into effect every detail given them by the Government officers. To this day these men continue to grow pears, while their neighbors are entirely out of the business. They are charged with being lucky, but there is no luck in fighting pear blight; it is careful attention to details and constant watchfulness. Among those who have been successful in fighting pear blight is Howard Reed, of Marysville, California. Mr. Reed, with 6,000 Bartletts, has lost relatively few, although the difficulties he had to overcome would have discouraged the average man. Three years ago his orchard was under water on account of the overflow from the Yuba River, and he was compelled to fight pear blight from boats and rafts. To show you how well he has won out in the fight, I will simply state that his crop two years ago was fifty carloads of first-class fruit, which he shipped to Eastern markets. Besides his green fruit, he dried something over twenty-five tons. I cannot help pointing to $\mathrm{Mr}$. Reed as an example for everyone to follow. $\mathrm{He}$ has made doubly good because he had to fight not only the blight but the mossback community in which he lived.

In the foothill districts of Eldorado, Placer and Nevada Counties, to the east of Sacramento, the loss has been exceedingly light. The growers in these sections began their fight at an early stage of the game and have kept it up unceasingly, so that at this time there are probably no 
fewer bearing pear trees than there were four or five years ago. In Placer County alone, at the time I first began my work there, ten inspectors, including the horticultural commissioners of the county, were put on, and the work of eradication was thoroughly done.

It would be very difficult to tell how many trees were lost in California over the entire state, but the figures taken from the carload shipments will tell the story pretty well. In 1900 California shipped 2,115 carloads of pears and in the same year 7,275 tons were dried, and perhaps half a million cases were canned. In 1907 only 1,039 cars were shipped and only 500 tons were dried. We have no data on the canned product, but it is well known that it fell off correspondingly. Such figures should strike terror into any community whose industry is that of growing pears and apples.

In the Rogue River Valley and in Southern Oregon we find a magnificent soil for pear and apple growing. At this time, with the valley only partially developed, the estimated value of the orchards reaches far into the millions. Pear blight has not been in the valley very long, but it is here and must be considered seriously. Only in three or four cases has it done any serious damage, and the total loss for the entire valley in pears and apples is probably not more than 2,000 trees. The highest recorded loss in one orchard is perhaps 500 or 600 trees, and this loss might have been avoided if the owner had taken the proper steps in eradicating a very few cases of hold-over blight. Another orchard lost nearly 200 trees, but these were mostly infected and practically destroyed before it was known that blight existed in the valley. The writer first came into the valley in 1907 , and since that time a very strenuous fight has been kept up. As in California, we had to fight stupidity and ignorance, but, for the most part, the growers have swung into line and are putting up a good fight. Very slight losses have occurred during the past two years, and these losses have been mostly in the villages and towns, and in the old home orchards, where it is difficult to make the owners see the necessity of cleaning up. The commercial orchards have done excellent work. 



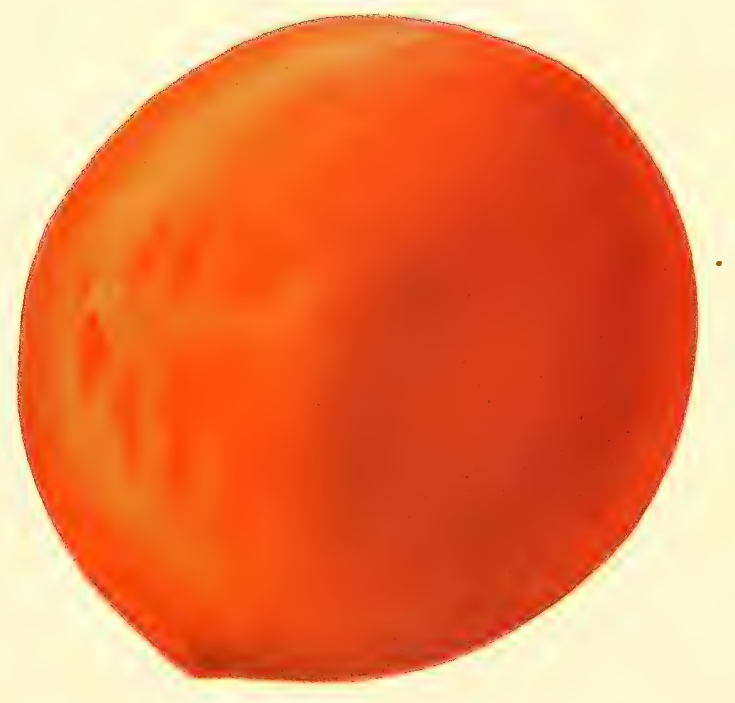

ELBERTA PEACII 
Even the largest orchard; in the valley have demonstrated the effectiveness of careful eradication. At this time it is a pleasure to visit them and see the heavily laden pear and apple trees with not a blighted spur or twig upon them.

The importance of the pear blight problem to the horticultural interests of the Pacific Coast states emphasizes very clearly the value and necessity of plant pathological work. What each district needs is a strong man who is both scientific and practical, for handling such a difficult problem. Not only does each district need the constant and careful attention of a trained pathologist, but it needs inspectors and commissioners who will see to it that the horticultural statutes are rigidly enforced. If a grower chooses to lose his crop by any disease which is not considered contagious or spreading, and which may readily be controlled by simple spray treatments, it is his own lookout; but where his pears and apples are a source of general infection from pear blight it becomes a matter for the district commissioner and local inspector. There is only one remedy, and that is to increase the inspection and make it rigid. Perhaps one other thing might be added. It would be a wise plan for each county or district to appoint a large number of volunteer inspectors who would serve without pay in their own interest, but who would be vested with authority to inspect and condemn within their immediate neighborhood.

At this time the Rogue River Valley has the best equipment for fighting blight known to the country. In Jackson County alone, besides a pathologist in charge, there is a chief inspector and four deputies. These men repori daily to the central office, and keep a careful record of their work. In addition, there are over fifty deputy horticultural commissioners, so distributed as to give each neighborhood one or more men who work in conjunction with the inspectors. These men are given full authority to enforce the horticultural laws. Being owners, they have a direct interest.

To those who have read the preceding chapters carefully, it may seem unnecessary to add anything more, as it is believed that all of the important facts about pear blight 
have been clearly stated. However, a resume will bring before us all the pertinent facts so that the reader may see at a glance what he may want to know without reading the text again.

1. The history of pear blight dates from the year 1780 , the first record was published in 1794 in the transactions of the Massachusetts Society for the Promotion of Agriculture. This first paper on pear blight gave to the highlands of the upper Hudson the distinction of being the birthplace of the disease. However, at the time of the discovery, the disease had a wider spread throughout the New England states than has been recorded.

2. The disease known as pear blight is not known outside of North America. Europe, Asia, Australia and all other parts of the known world are free from the disease.

3. The true character of the disease was worked out by Professor T. J. Burrell, of the University of Illinois, in 1878 , and was published to the world in 1880. Dr. Burrell found that the disease is caused by a small germ belonging to the great family of bacteria, which are minute, microscopic plants, the smallest vegetable organism in the world. The pear blight bacillus is only $1-50,000$ of an inch in diameter and about 1-25,000 of an inch in length; under the miscroscope, when magnified 1,000 diameters, its appearance is that of a hyphen (-).

4. The pear blight germ attacks all species belonging to the pome or apple family and also in a small way infects plums and the apricot. Among the cultivated fruits, therefore, it attacks the apple, pear, quince, loquat, plum and apricot. The following wild fruits indigenious to the Pacific Coast states are also attacked by it. I shall give the common names and after them the botanical or scientific names, so that students of botany may be able to look them up:

(a) Service berry or June berry (Amelanchier alnifolia) .

(b) Thorn apple or haw (Crataegus douglasii).

(c) Christmas berry or Toyon (Heteromeles arbutifolia). 
(d) Wild pear or apple (Pyrus rivularis).

(e) Mountain ash or rowan (Sorbus occidentalis).

There are many more species of the above genera to be found in the Eastern and Southern states, but a knowledge of the fact that all pome fruits blight should be sufficient.

5. The damage by blight in the Eastern and Southern states has been such that practically all of the better varieties of pears have gone out and commercial pear growing is an industry of the past.

6. The blight has spread into every known section of the United States, Southern Canada and Northern Mexico; only a very few small districts still remaining free from it.

7. The first appearance of the blight is made evident by the blossoms and young shoots becoming withered and black, finally drying up. Later, branches and limbs, as well as the bodies and root system, become infected. Even the fruit may become infected and wither away.

8. The infections first noted in the spring come from hold-over cases which have resulted from the previous year's infection. These hold-overs may be found in the larger limbs, bodies and roots of the pear, apple, quince, loquat and even our wild fruits, though less frequently. During the blossoming period these hold-overs ooze and this gummy substance, which is filled with the bacteria, become points for the starting of new infections in the blossoms and twigs.

9. The germs from the hold-overs are carried about by bees and other insects. Biting and sucking insects cause infections in the young twigs, and even the bodies. Sapsuckers, or woodpeckers, may also spread the blight. The use of pruning tools, not disinfected, also spreads it. The blight may also enter small growth cracks in the twigs, limbs, bodies and roots, and through crown galls.

10. Weather conditions favor the spread of blight, as well as favoring infection. Dry weather tends to prevent, not only the spread of infection from tree to tree, but also the spread of the disease in the tree itself. It is as easy to understand this as it is to understand that dry weather prevents growth and germination of seeds and plants. 
11. Thunder, lightning and other atmospheric disturbances have no influence whatever on the disease known as pear blight. The precipitation which accompanies them is the only factor besides warmth.

12. The only way to control blight is to remove all cases of hold-over before the blossoming period begins. Hold-overs removed during the blossoming period do not insure that some infection has not taken place from them. To remove hold-overs, or rather to find them on the rough bodies use a gouge or some other instrument with which to expose the tissues beneath. A water-soaked, reddish condition of the soft bark indicates infection, which should be antiseptically removed.

13. The antiseptic to be used should be bichloride of mercury, or corrosive sublimate, and use no other. This disinfectant should be used at a strength of one to 1,000 , or perhaps stronger, but never weaker. The use of the various substitutes in a senseless practice, as there is nothing cheaper or more effective as a disinfectant than bichloride of mercury. It is a deadly poison and must be kept away from children, and the containers should be plainly labeled so that unsuspecting persons may not be poisoned.

14. There are no remedies for pear blight, and all socalled patent washes or other "remedies" should be avoided. Anyone who claims to have a cure for pear blight is a "fake," and should be treated accordingly. Those having "remedies" for sale have no standing whatever; if they had they would not oppose every scientific fact known.

15. Summer cutting of blight should always be done, but the work, to be effective, must be done carefully. Always be sure to get below or above the point of infection. If infection is found in a fruit spur or water sprout never break them off unless you know how far the infection has gone. There is no further danger in the dead spur, but rather in the infection which has advanced beyond it. Breaking off the spur and then applying the disinfectant is not eradicating the blight. Never leave an infection until you know that there is no further danger from it. Remember there is no such thing as "pretty good work;" the work is either good or bad. 
16. In order to render the fighting of pear blight more easy, trees should be pruned in the vase or open head form. Never grow a tree with a main leader or center. Keep all water sprouts and fruit spurs off the body and main limbs of the tree. Let no water sprouts come up from the crown of the tree or the root system. Be sure to cut out all crown galls.

17. When blight is prevalent or when seasons conducive to blight occur, extreme caution should be used in the matter of using stable manure, commercial fertilizer or applying too much water. Irrigation practice should be studied carefully, not only in connection with blight control, but with benefits or injuries which may result to the soil.

18. The only way to keep blight under control is to increase the inspection and make it rigid. If a grower is caught experimenting, or not following out the directions for eradicating blight according to the letter of the law, force him by law to do whatever the inspector has ordered. I believe besides the regular corps of inspectors we should have volunteer inspectors who will look after their own interests by investigating the condition of neighboring orchards. Their appointment may be made in the regular way, making them officers of the law having the right to enter upon a neighbor's premises. If this had been done in certain districts the past year, several infection centers would have been wiped out. There would have been no infection and a good many dollars saved.

19. Lastly, in closing permit me to say that as individuals you have a right and a duty to follow the advice and instructions which have been given you for eradicating and controlling blight. A government officer, who has had technical and practical experience all over the United States for a period of years, certainly knows the situation, and there is no reason for doubting his words.

As a friend, I ask you all not to trifle with blight; it is too serious a matter. The value of the fruit interests is too great to be trifled away by individuals who have neither knowledge nor practice sufficient to devise more efficient means than have already been worked out by the pathologists of the United States Department of Agriculture, 
whose entire energy is given to the practical side of fighting diseases. You have a United States Department of Agriculture, therefore, respect the advice it is able to give you through its agents. 


\section{CHAPTER XVII.}

\section{PREPARATION OF SPRAYING MATERIALS. COMPILED BY J. U. MCPHERSON.}

\section{INSECT PESTS.}

For the intelligent and practical employment of insecticides, it is necessary to comprehend the nature of the pests and the injury inflicted by them. The great mass of harm to growing plants from insects, falls under two distinct heads, based on two distinct principles of food economy, viz., Biting insects, (Mandibulate) which actually masticate their food and swallow it, and sucking insects (Haustellate) which absorb juices. Each group involves a special treatment. For insects that chew and swallow their food (which include the majority of dangerous larvæ, all beetles, and the locust family) the best method of control is by spraying with poison that may be safely applied to the leaves or other parts of the plant attacked. Thus the insect will swallow a portion of the poison with its food.

Poison should never be applied where the parts themselves are to be shortly used for food, either by man or beast. Spraying under this head must be done when the foliage is on the trees.

All sucking insects are destroyed by applying insecticides directly to them or to their eggs in the dormant season (killing by contact) as it is impossible to poison them on account of their method of feeding, which is by inserting their proboscis and sucking sap from the plant. The application can be made either in summer or winter, as the case may be.

\section{FUNGUS DISEASES.}

Cultivated plants are beset by many enemies. Some of these belong to the animal and some to the vegetable kingdom. To the former belong the insects, and to the 
latter the parasitic fungi. By the development of these parasites on growing plants or trees, the peculiar malady known as fungus diseases is produced. The term "fungi" takes within its scope the lower forms of plant life, such as molds, mildews, rusts, blights and similar organizations. Instead of growing in the earth as do trees or bushes, they grow on, and take their nourishment, for the most part, from the higher orders of plants that we cultivate in our orchards and gardens. Parasitic fungi in many of their forms are enemies of the farmer and fruit grower, partially, and often entirely, destroying the crops. Spraying for fruit diseases is preventative rather than curative. The work of prevention should begin in the dormant season, when strong remedies may be used to destroy the spores or germs. This can be thoroughly done at this season, on account of the absence of any foliage. For all fungus diseases, there is no better remedy in the dormant season than Remedy No. 1 given in this report; and for spraying for fungus diseases when plants are in leaf, all things considered, the Bordeaux mixture has been found the most effectual.

REMEDY NO. 1.

To be used in the dormant season for scale, pear leaf blister-mite, aphis eggs, etc., or fungus diseases of any kind.

\section{Formula.}

Sulphur 20 lbs.

Unslacked lime $40 \mathrm{lbs}$. Water 60 gals.

For a greater or less quantity the ratio would be $1 \mathrm{lb}$. salt, 2 lbs. sulphur, $4 \mathrm{lbs}$. lime to every 6 gals. water.

Directions-Place 20 gallons of water in a boiler and heat to a boiling point. (The amount of water should be varied according to the size of the boiler). While this is being done, place the lime, sulphur and salt in a large barrel or vat and slake the lime by adding water in sufficient quantities to do so properly, keeping it well stirred, 
mixing the lime, sulphur and salt thoroughly. When this operation is completed add enough water to the contents of the barrel or vat to reduce it to a somewhat thick liquid and strain the mixture into the boiler. (Common wire window screen netting fastened to a wooden frame is the best). Boil the mixture for one and one-half hours, or longer. When ready for use, dilute with enough water to make 60 gallons. Use this spray hot, as better results are obtained.

In extreme cases of scale two sprayings, a few days apart, should be resorted to.

This mixture is seldom used now, the manufactured preparation taking its place.

REMEDY NO. 2.

For codling moth, or leaf eating insects.

\section{Formula.}

Six ounces Paris green diluted with 50 gallons of water.

Directions-Place the poison with an equal quantity of powdered lime in a small vessel with enough water to make a thin paste. Let it stand for about 10 hours before using. Keep the liquid well agitated when spraying, in order that it may be evenly distributed on the tree.

\section{REMEDY NO. 3.}

For codling moth, or leaf eating insects.

\section{Formula.}

White arsenic (powdered)

Salsoda (lump) 1 pound

Water 4 pounds 1 gallon

Directions-Place arsenic and salsoda in a vessel containing one gallon of hot water and boil for 15 minutes, or until it is all dissolved. Put the liquid in a jug, cork it up and label it "Poison" in the plainest manner, and lock it up securely until needed. 
Use 1 pint of this liquid to each 50 gallons of water, adding three pounds of quick-lime, slaked in water, before using.

Note-For the last spray use $6 \mathrm{lbs}$. of salsoda in preparing the arsenic and use 1 quart of glucose to each 50 gallons of the spray, instead of the lime. This is advisable in order to avoid having so much lime on the apples at picking time.

REMEDY NO. 4.-LEAD ARSENATE.

For codling moth, or leaf eating insects.

Formula.

Arsenate of lead 5 to 6 pounds Water 100 gallons

REMEDY NO. 5.

For Aphis.

Formula

American concentrated lye 2 pounds

Resin 6 pounds

Water 55 gallons

Directions-Place the lie and resin in a boiler holding 25 gallons of water. Boil until the lye and resin are dissolved. Strain into the spraying tank, or barrel, adding enough warm water to make 50 gallons. Use hot, as the resin will precipitate if the liquid gets cold.

REMEDY NO. 6.

Formula

Whale oil soap 1 pound

Kerosene 2 gallons

Water 1 gallon

A good grade of hard or soft soap may be used. 
Directions-Dissolve the soap in one gallon of water by heating. Remove from the fire. While hot, add two gallons of kerosene and churn the liquid with a force pump by pumping the liquid back into the vessel that contains it until a perfect emulsion is formed. It will then be a creamy substance. One gallon of the mixture should be diluted with 9 gallons of water when spraying apples, pears or prunes. When used on peaches and rose bushes, it should be diluted 1 gallon to 15 gallons of water.

REMEDY NO. 7.

The Bordeaux Mixture-For fungus diseases, to be used in the summer time.

\section{Formula}

Water 60 gallons

Copper sulphate 6 pounds Unslaked lime 4 pounds

Directions-Dissolve 6 pounds of copper sulphate (bluestone) in water in a wooden vessel to prevent corrosion of metal. It dissolves most readily in hot water. Add several gallons of water. Reduce 4 to 6 pounds of good lime, that which has not been air-slacked, to a lime-milk, by the slow addition of water and constant stirring with a hoe. Add several gallons of water. Strain both bluestone, water and milk of lime through a wire screen into a common wooden tub, mix carefully with a hoe, until a pretty blue mixture is the result. Pour this mixture into your spray-barrel, add water enough to make 45 gallons in all, stir well with a hoe, or with an automatic stirrer in the barrel, when the mixture is ready for use. The writer prefers the use of the hoe in all cases to any automatic device. Cut a hole in the spray barrel, large enough to hold the entering pipe to the pump and allow the insertion of a hoe as well. The man who manages the pump can, at the same time, occasionally stir up the mixture.

TESTING.

To determine whether the mixture is perfect, that is, 
if it will be safe to apply to tender foliage, a simple test may be used. Insert the bright blade of a penknife in the mixture, allowing it to remain there for at least one minute. If metallic copper forms on the blade, or, in other words, if the polished surface of the steel assumes the color of copper plate, the mixture is unsafe and more lime must be added. If, on the other hand, the blade of the knife remains unchanged, it is safe to conclude that the mixture is as perfect as can be made.

\section{STOCK MIXTURE.}

If spraying is to be done on a large scale, it will be found much more convenient and economical in every way to prepare what are known as stock solutions of both the copper and the lime. To prepare a stock solution of copper sulphate, procure a barrel holding 50 gallons, weigh out a hundred pounds of copper sulphate and after tying it in a sack, suspend it so that it will hang as near the top of the barrel as possible, fill the barrel with water, and in two or three days the copper will be dissolved. Now remove the sack and add enough water to bring the solution to the 50 gallon mark previously marked on the barrel. It will be understood, of course, that this second adding of water is merely to replace the space previously occupied by the sack and the crystals of the copper sulphate. Each gallon of the solution thus made will contain two pounds of copper sulphate.

Under all ordinary conditions of temperature there will be no material recrystalization, so that the stock preparation may be kept indefinitely. Stock lime may be prepared in much the same way as the copper sulphate solution. Procure a barrel holding 50 gallons, making a mark to indicate the 50 gallon point, weigh out 100 pounds of fresh lime, place in the barrel and slack it. When slacked, add sufficient water to bring the whole mass up to 50 gallons. Each gallon of this preparation contains, after thorough stirring, 2 pounds of lime. When it is desired to make Bordeaux mixture of the 50 gallon formula, it is only necessary to measure out 3 gallons of the stock copper solution, and 
after thoroughly stirring, 2 gallons of stock lime. Dilute each to 25 gallons, mix, stir and test as already described. One test will be sufficient in this case; in other words, it will not be necessary to test each lot of Bordeaux mixture made from the stock preparation, provided the first lot is perfect and no change is made in the quantities used. Special care should be taken to see that the lime-milk is stirred thoroughly before applying. As a final precaution it will be well to keep the stock copper sulphate and stock lime tightly covered.

REMEDY NO. 8.

For Aphis.

Formula

Whale oil soap 1 pound

Quassia chips 1 pound Water 10 gallons

Directions-Boil the quassia chips in two gallons of water for two hours. In another vessel dissolve the whale oil soap in two gallons of water by heating. Mix the two together and dilute to 10 gallons. Warm water is preferable.

REMEDY NO. 9.

For Cabbage Aphis.

Formula

Whale oil soap .1 pound

Water 10 gallons

(Any good grade of hard soap will answer).

Directions-Dissolve the soap by heating in one gallon of water; then add nine gallons of water to this. Spray the infested plants with an atomizer or hand pump with the nozzle turned so the under side, or any part of the leaves can be reached. Apply with as much force as possible, so that the mixture comes in contact with the insects. From 
one to three applications of this will rid the garden of this pest.

\section{REMEDY NO. 10.}

For ants or other insects living underground-bisulphide of carbon.

Locate the ant mound or nest. Take a small iron bar or other instrument and penetrate the ground to the proper depth about 1 foot apart, over the infested area. Pour in about 1 tablespoonful of carbon in each hole, immediately covering the hole with earth. One treatment is usually sufficient.

Caution-Bi-sulphide of carbon is an explosive and no fire should be allowed near it.

\section{ANIMAL PESTS AND REMEDIES.}

\section{JACKRABBITS.}

A good rabbit-tight fence is the best and safest remedy, but in the absence of this some other safeguard should be sought for. Trunks of trees may be protected by wooden guards made of slats woven together with wire, or by being wrapped with cloth, burlap or even good, strong paper. For destroying jackrabbits in a wholesale way the following remedy is good:

Dissolve 1 ounce of strychnine in 5 gallons of water by heating. Place a small bundle of good clover or alfalfa hay in an inclosure where no domestic animals can get to it, yet open enough for the rabbit to get at the hay. Thoroughly dampen it with the liquid poison. In the absence of other food the rabbits will eat the hay, which means certain death to them.

Caution-Care should be taken to keep all other animals away from the poisoned hay and what remains after the desired results are obtained should be burned without delay. 
MICE.

Mice sometimes become quite a serious pest, eating the bark from the roots near the surface and as high on the body of the tree as they can reach.

Treatment-Keep all rubbish out of the orchard. Clear away all of the grass and weeds around the trees and do not allow the trees to be banked up with earth, as it makes a harbor for the mice. Use one of the formulas for poisoned grain given below.

Remedy-Dissolve 1 ounce of strychnine in 2 ounces of acetic acid. Then add one ounce of oil of rhodium. Dilute with enough water to thoroughly soak one bushel of wheat. Scatter the wheat around the trees and near the runways where the mice are found. One tablespoonful will usually be sufficient in one place.

Caution-Keep the fowls away from the poisoned wheat.

\section{KANSAS FORMULA FOR POISON FOR MICE.}

Remedy No. 2-One ounce of green coffee berries are pulverized and mixed with the whites of two eggs and allowed to stand for at least fourteen hours. An ounce of strychnia sulphate is dissolved in half a pint of boiling water. To mix, add a little warm water to the coffee egg mixture, and after stirring well strain this through a coarse sieve into the mixing vessel. Then add a pint of molasses or syrup. To the hot solution of strychnine add one and one-half ounces of alcohol, and pour this into the other mixture slowly, stirring thoroughly.

The mixture can now be put into a glass jar and used at any time. The amounts above mentioned should do for half a bushel of wheat or rye, and the grain can be poisoned in any quantity desired at a time by pouring over it the proper amount of liquid and mixing thoroughly, so that each grain gets its portion; then spread out on paper to dry. Do not forget that you are working with a deadly poison, so do not run any risks. Keep it where neither children nor valuable fowls may get it. A few grains in or near each burrow will do the work. 




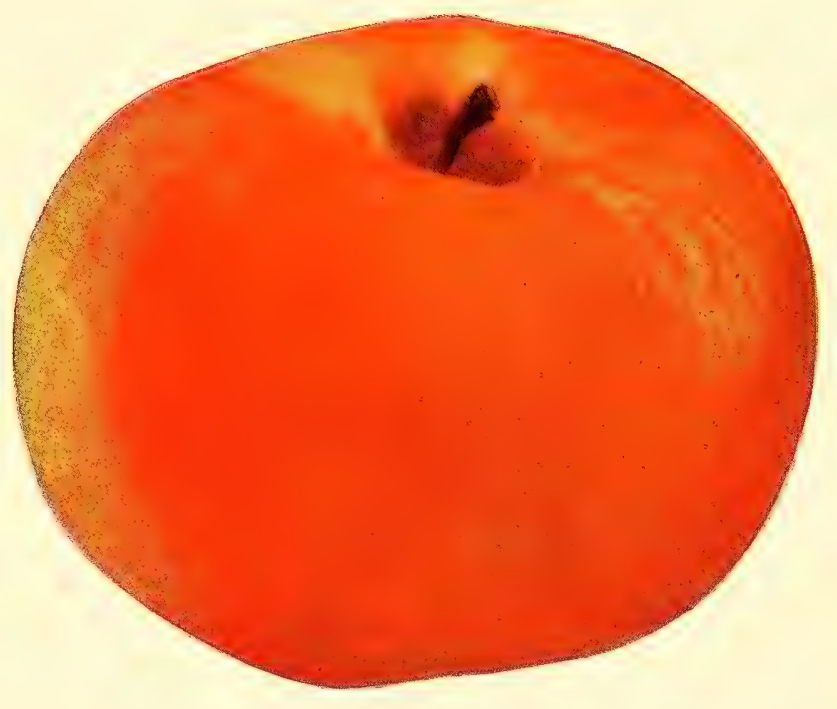

WAGENER 


\title{
CHAPTER XVIII.
}

\section{REPORTS OF DISTRICT INSPECTORS.}

\author{
DISTRICT No. 1.
}

Coeur d'Alene, Idaho.

Mr. JOHN U. McPherson,

State Horticultural Inspector,

Boise, Idaho.

Dear Sir-As requested I send report of District No. 1, comprised of Bonner, Kootenai and Shoshone counties, for the years 1911 and 1912.

I am glad to report that our nurserymen ship in much better trees than when I first inspected stock in 1907, and I think the credit is partly due to our inspection law, and will say the same about our orchards. We have clean fruit because all orchardists are compelled to spray, and if the horticultural appropriation were three times as large, then the field workers could boast of one of the cleanest fruit states in the Union, but where an inspector is limited to one hundred days a year, he does not get time to go over his district.

In District No. 1, in 1911, 262,600 trees were planted, and in $1912,221,460$ were planted, making orchard acreage up to November 5th, $1912,16,423$ acres.

I have traveled, through the years 1911 and 1912, 3,084 miles.

All our truck and large orchardists are spraying now, this fall, with sulphur-lime spray, 10 to 1 . We have no San Jose scale in this district, but we have the rest, including scab, which is harder to fight than any other pest, as we have 40 inches of precipitation in this locality.

The number of trees planted in the past five years are: $1907,1,714$ acres; $1908,6,540 ; 1910,8,403 ; 1911,13,655$; $1912,16,423$.

The largest amount of appropriation for one year's 
work ever allowed this district, and I to pay my own expenses, was $\$ 500$, not one-third enough to do the work.

Yours sincerely,

(Signed)

WILLIAM BUCKLEY,

Deputy Inspector, Dist. No. 1.

DISTRICT No. 2.

Moscow, Idaho.

Mr. J. U. McPherson,

State Horticultural Inspector,

Boise, Idaho.

Dear Sir-I respectfully submit the following report for District No. 2, which comprises all of Latah county and that part of Nez Perce county situated north of the rimrock. It is fifty miles long and from thirty to forty miles wide. The railroad connections are very bad and it is necessary to travel on two different railroads to get to many points in my district, the greater part of the traveling being done through Washington.

There are a number of very good commercial orchards in bearing at this time, and a large number of orchards are set out each year.

Latah county has become quite famous in the past two years for its apples. In 1911 the Wagner apples in Latah county took sweepstakes at the National Apple Show at Spokane, and in 1912 we took second prize at the Apple Show on our mixed car.

The principal varieties of apples raised here are the Rome Beauty, Wagner and Jonathan. Many other varieties are grown in this district, but these I consider our best apples. Most any variety of small fruit can be raised here, but very little of such fruit is raised commercially.

Our crop of apples for 1911 was only about two-thirds of what it has been for 1912. We have an exceptionally large crop this year, as is reported from all districts, and the growers report that it is hard to market their fruit. However, there has been a good cannery installed at Juliaetta, and a good vinegar factory at Moscow. The 
two by-products houses are aiding the farmers in disposing of their products.

The worst pests with which we have to contend in my aistrict are codling moth, blight, apple scab, and scale in the southwestern part. The codling moth has not been very bad this year, but the apple scab has been quite bad, owing to the heavy rainfall in our county. The blight is getting quite badly scattered, and needs close attention to prevent it spreading further infection. The scale is quite a problem in and around Juliaetta, as it is found on most all the underbrush for miles up and down the creek. Some of this land is state land and will have to be cleaned up by the state.

We must have more money to carry on the inspection work, or little or no headway can be made. District No. 2 is allowed $\$ 400.00$ per year, but some additional sums have been added to this each year by the Board. There is absolutely nothing in the work for a man at wage per year, when you take into consideration his board and other expenses.

The fruit growers are much interested in inspection work and I believe, with a combined effort, that we can get a good appropriation to carry on the inspection work in the state this coming year.

I presented a petition to the county commissioners, which was signed by the leading fruit growers of my district, asking for a sum of money to carry on the work, but they were unable to help out in our work this year.

(Signed)

Respectfully yours,

W. C. EDMUNDSON,

Deputy Inspector, Dist. No. 2.

DisTRICT No. 3.

Lewiston, Idaho.

Mr. J. U. McPhersoN,

State Horticultural Inspector, Boise, Idaho.

Dear Sir-At your request, I submit the following report as to the general conditions of the orchards in $\mathrm{Nez}$ Perce county. 
I consider the orchards in this district to be in first class condition, especially do I find the commercial orchards well taken care of, and almost entirely free from the various pests and diseases. Spraying for scale, moth and scab has become general throughout the district.

The fruit growers of this district are much in sympathy with the inspection work, and they are beginning to realize the benefits derived from it.

All nursery stock shipped into this district is carefully inspected and will do much towards preventing the spreading of the different diseases and pests.

The acreage of commercial orchards is steadily increasing, about five hundred acres being planted yearly, while some of the old farm orchards of poor varieties are being taken out.

I believe the fruit trees of this section, at this season of the year, to be in prime condition for wintering, and to be generally free from all injurious diseases.

In carrying on the work this year of 1912, I have traveled 1,650 miles.

(Signed)

Yours respectfully,

GEORGE E. AMES,

Deputy Inspector, Dist. No. 3.

\section{District No. 4.}

The work of this district was placed in the hands of Henry T. Murray, of Grangeville, Idaho, April 1911, when he was appointed Deputy Inspector for that district, and Mr. Murray continued in the work until June, 1912, when he resigned and went into business for himself.

District No. 4 comprises the counties of Idaho, Clearwater and Lewis, and has only a very small appropriation allotted to it considering the size of the district and the amount of travel which is necessary in order to reach the different fruit districts. However, during the months when Mr. Murray was inspector he traveled 2,163 miles, and worked 1631/4 days. He inspected $1603 / 4$ acres of apples, $10 \%$ of pears, and 445 acres of mixed fruit besides 758 town lots. 
Mr. John A. Powell of Grangeville was appointed in September to fill the unexpired term in this district and his report for the period follows:

Mr. JoHn U. McPherson,

Grangeville, Idaho.

State Horticultural Inspector,

Boise, Idaho.

Dear Sir-In compliance with your request, I wish to give a general report of the work in this district for the unexpired term of my predecessor, and for the time only that I have been in office. I find that general conditions in the orchards of this district, as far as I am able to judge, are above the average for this time of the year. Regarding the increase in orchards for the three months I have filled the position of deputy inspector, shipments of trees in the district are about as follows:

Apples, 1,400; pears, 400; peaches, 650 ; prunes and plums, 300 ; cherries, 1,400 ; berries, 3,000. As regards the acreage, I cannot tell increase until same are planted.

Number of miles traveled in pursuance of official duties for October, 210; November, 291; December, 324, making a total of 825 .

I find that people generally are becoming more interested in horticulture, and are giving the same more attention and are making marked progress in the eradication of diseases.

(Signed)

Respectfully yours, JOHN A. POWELL, Deputy Inspector, Dist. No. 4.

DisTRICT No. 5.

MR. J. U. McPHERSON,

Cambridge, Idaho.

State Horticultural Inspector, Boise, Idaho.

Deax Sir-Complying with your request of recent date I herewith submit report of work done and miles traveled by me as deputy inspector of District No. 5 in 1911 and 1912. 
I began my duties as inspector of this district in April, 1911, following the resignation of $\mathrm{Mr}$. Featherston, my predecessor, who had done commendable work in bringing the orchard conditions in this district up to a higher standard than had heretofore been attained.

This district is composed of Washington and Adams counties. Adams county has a greated altitude than Washington, hence a cooler and shorter season. The cool nights of Adams county seem to be unfavorable to insect pests of the lower country, so that, as yet, spraying has not become necessary in this county.

We have the scale and codling moth both well under control, but the blight has given us much concern in nearly every part of the district. In some parts of the district it has been very troublesome. We have been waging war upon it by removing all the blighted branches and burning them, and in some instances destroying the whole tree. There are some very excellent fruit lands in both counties, and orchards are much in evidence. In 1911 there was not more than a one-fourth crop harvested, while the year 1912 has given an abundant harvest.

We have 7,000 acres of fruit trees in this district, about 6,000 acres of which are apples, and about 1,000 acres of prunes and peaches, with a few acres of pears. In 1911 we shipped 24 cars of prunes, and about 50 cars of apples, also 10,000 crates of peaches, while in 1912, we have shipped 50 cars of prunes, and have packed 131,950 boxes of apples, only a part of which have been shipped. Also 1,300 boxes of pears, while the peach pack will scarcely reach 1,000 boxes.

During the two years to November 1, 1912, I have worked $2821 / 2$ days, and traveled 5,299 miles.

In conclusion, I would say that there is preparation being made to plant quite a large acreage the coming year and it is hoped by all the commercial orchardists that the inspection work will be made more and more proficient, consequently more funds will be needed to carry on the work in a proper manner.

Yours very respectfully,

(Signed)

D. B. WEBBER, Deputy Inspector, Dist. No. 5. 
DisTRICT No. 6.

Payette, Idaho.

Mr. J. U. McPHERSON,

State Horticultural Inspector, Boise, Idaho.

Dear Sir-Complying with your request, I submit the following report for District No. 6, for 1912. As my appointment began March 16, 1912, and this being my first season, I cannot give a full report for the biennial season. My predecessor worked for some time, for which I have no account.

District No. 6 comprises the north half of Canyon county, covering the entire Payette river valley, a portion of the Snake river valley, and extends about seven miles below the city of Payette, and includes all of Boise county. The orchard interests in Boise county are small, so the most of the inspector's work lies in the Payette valley.

The principal fruits shipped from this valley are apples and prunes, the principal varieties of apples being Jonathan, Rome Beauty, Winesap, Arkansas Black, Grimes Golden, Gano and Ben Davis. Of the prunes, the Italian. Of the peaches, Early and Late Crawford, and Elberta. Pears, Barttett, Anjou and Winter Nellis. All kinds of berries and small fruits do well, but are not raised to any great extent. I think the fruit crop over the entire district is fully as good, or better, than ever before, and the orchards are in fine condition. I found considerable San Jose scale in the spring, but I believe all have sprayed, and I see very little at this time. Orchardists have also sprayed for codling moth pretty thoroughly, so I would estimate that about $85 \%$ of the apples are free from worms and scale.

As near as I can estimate the number of acres in District No. 6 are as follows: Apples, 21,816; prunes, 1,349; peaches, 1,521; pears, 467; mixed fruit, 560, making in all about 25,713 acres, about one-tenth of which is in bearing.

Up to November 15,1912 , there has been shipped 520 
cars of apples, 287 cars of prunes, 50 cars of peaches, 5 cars of pears, and about 3,600 crates of fruit by express, besides numerous small shipments by freight. There remains about 300 cars of apples to be shipped which are now in storage.

The number of days employed in inspection so far is 158 , and miles traveled about 3,822 .

In closing I will say that I have the support of practically all the growers of this district. Some oi the small orchardists have not always shown the disposition to comply with the law, but I have finally induced them to meet its requirements without recourse to the court.

Hoping this report will meet with your approval, I remain,

(Signed)

$$
\text { Very truly, }
$$

A. B. KERN, Deputy Inspector, Dist. No. 6 .

\section{District No. 7.}

Caldwell, Idaho.

Mr. JOHN U. McPHERSON,

State Horticultural Inspector, Boise, Idaho.

Dear Sir-Complying with your request I herewith submit a brief report of the horticultural inspection work done during the years 1911-1912 in my district, No. 7, which comprises all of Owyhee county and the Boise valley in Canyon county.

I was appointed inspector the latter part of March, 1911, consequently this report will not cover the entire period of the years 1911-1912, as quite a lot of work was done by my predecessor.

Since the report of 1910 , the acreage in this district has vastly increased, and while I have not visited all the new orchards the following is a fairly accurate amount of the various kinds of fruit grown:

Apples, 14,000 acres; prunes, 650 acres; pears, 125 acres; Peaches, 140 acres; small fruits, such as raspberries, dewberries and strawberries, 175 acres. 



$$
\text { is }
$$


The year 1911 was almost a failure in the fruit line, owing to heavy freezes and hail in parts of my district, for instance, the Parma-Roswell country had a hail which injured the fruit so that little was shipped from that point. Caldwell, Nampa and Middleton regions were short from freezes. There were shipped from this district during the year but 43 cars of apples and 49 of prunes. Apples netted about $\$ 1.10$ per box, prunes about 50 cents per crate. The year 1912 was an exceptionally good fruit year, 135 cars of apples and 54 of prunes being shipped, besides there are in storage about 20 cars of apples. There was nearly 150,000 pounds of dried prunes, of which about 50,000 are sold at this writing at $6 \frac{1}{2}$ cents per pound. I am unable to give net prices for apples as the returns of sales are not available. Prunes netted about 50 cents per crate.

Upon taking charge of this work I found that there was in every orchard San Jose scale to some extent, and in one or two instances it was quite bad, but I am glad to report at this time there is but little to be found in any of the orchards. I find most of the trouble in controlling pests and diseases is to be found on town lots where the owners are not interested, but the farmers and fruit growers are anxious and willing to eradicate the pests and diseases and to co-operate with the Department in so doing. The season of 1912 was quite bad in the way of blight during the months of June, July and August, and we made a hard campaign on it and caused most of the blight to be cut out. The crops this season are practically free from codling moth. I believe $95 \%$ of the apples are free from worms owing to the growers spraying so well for the codling moth, and I find that where the power sprayer is used that results are much more satisfactory, in fact, it seems to me to be almost impossible to do satisfactory work with a hand power sprayer.

I would suggest that the horticultural laws should be amended so that when it becomes necessary for an inspector to eradicate pests or diseases in an orchard that the costs be assessed against the property and not have conditions remain as they are now, that is, to sue and get 
judgment and then try and collect. I am prompted to make this suggestion from the fact that during the past year I have had to have several orchards sprayed and one in particular that cost the state about $\$ 90.00$, and in trying to collect the same the county attorney is unable to get service and judgment, it being an estate, and he is not able to find all the heirs. Now if the law were such that this could be assessed to the property there would be no trouble to collect, as it would be collected the same as taxes. Another case I had was a non-resident. I could not find the party, who had left the country, mortgaged the property and, it is presumed, never intends to redeem it, in fact, the mortgage is now being foreclosed, and the cost of destroying this orchard, which I did, has to be paid by the state. I have often found it very difficult to find the owners of orchards, particularly on town lots where the owners are not in the county and no one on or in charge of the property. Some one may have the lots for sale, but are not agents on whom one could serve legal notice. There should, in my judgment, be some way that legal notice could be made in these cases that would be legal, and allow the inspector to care for the trees and tax same against the property.

I find that there are not sufficient funds for the proper enforcing of the horticultural laws, and I have been much handicapped in my work for this reason. To do the work as it should be done it requires all of a man's time, in fact, my district should not have less than three men most of the season, and all of their time. If the horticultural laws are good they should be enforced and the enforcement of them is what should be done, for if this is to be a horticultural country we must keep down all pests and diseases, and the only way to do that is to keep up the fight. The people, I am sure, want the laws enforced, and the horticultural interests protected and fostered. In the past two years I have had the support of the orchardists in my district and know that the majority, if not all, want the laws enforced and they also know that the Department has not had sufficient funds the past two years, for they petitioned the county commissioners to help the Depart- 
ment, but the commissioners did not think they could do so, consequently they did not appropriate any funds for this purpose.

In the next few years there will be planted in this district a vast amount of acreage in orchards, and will be the principal industry, and it must be taken care of.

I think there should be a law regulating the marketing of fruits, so that all of the fruit shipped shall be of a standard quality and pack. I find that some growers and shippers try to keep up a high standard, while others pack and ship most anything, which lowers the standard of our fruits in the markets, thereby working a hardship on those who try to raise the quality. One car of poor fruit shipped to the market does a vast amount of damage to the industry in this state.

Respectfully submitted,

(Signed)

EDGAR MEEK,

Deputy Inspector, Dist. No. $\%$.

DisTRICT No. 8.

Boise, Idaho.

HON. JOHN U. MCPHERSON,

State Horticultural Inspector, Boise, Idaho.

Dear Sir-I have the honor to report to you that conditions in District No. 8, during the past two years, have undergone a decided change. The first of the season of 1911 found Ada and Elmore counties with about 15,000 acres of orchards. San Jose scale infested nearly every orchard to such an extent that the commercial fruit was limited to about $70 \%$ marketable prunes, pear and apples. The codling moth, woolly aphis and pear blight were in nearly every section. The wormy apple reduced the shipment of apples to about $60 \%$. Young nursery stock shipped in from other states contained much infection of root gall, oyster shell scale, and peach borer. In one shipment I found egg clusters of the gypsy moth. All infected stock was promptly burned.

At the close of the season 1912 we have in Ada and 
Elmore counties about 20,000 acres of orchard and a good crop of practically clean fruit-about 425 cars of prunes free from insects and diseases.

The apple crop in this district is not unusually large, but it is of good quality, numbering about 225 cars.

The growers as a whole stand behind the inspector and it is with their co-operation that good results have been obtained. We have had some arrests and convictions, mostly for neglect to eradicate San Jose scale and to spray for codling moth. Every orchard was sprayed for San Jose scale and the apple and pear orchards were sprayed for codling moth from one to four times.

Our record of horticultural exhibits is good, Ada county having won county sweepstakes prize at the Intermountain Fair in 1912. At the Pacific Northwest Land Products skow at Portland, Oregon, Ada county won from Hood River the first prize on box of Yellow Newtons, and from Wenatchee the first and second prize on Winesaps. The prize money won by the growers and myself at the Idaho Intermountain fair was placed to the credit of the Horticultural Inspection fund to be used for horticultural work in Ada county.

During the year 1911 I worked as assistant deputy and handled the interstate nursery stock inspection and the inspection of the trees in the city of Boise only. During the year 1912 I was appointed deputy and have traveled 7,000 miles and have worked 207 days inspecting 15,000 acres of orchards.

One of the greatest needs in this district is a selling agency which would be associated with similar agencies or associations over the entire northwest, and through these agencies the products of the orchards should be handled.

In order to keep the inspection work going and to aid the growers in their work of producing good, clean fruit, a larger appropriation of money is now a necessity.

(Signed)

H. P. ASHBY,

Deputy Hort. Inspector.

Dist. No. 8. 
DisTRICT No. 9.

Twin Falls, Idaho.

MR. J. U. McPHERSON,

State Horticultural Inspector, Boise, Idaho.

Dear Sir-Complying with your request, I send a brief report of my work as horticultural inspector for District No. 9, for the years 1911 and 1912 to date.

District No. 9 includes Blaine, Lincoln and Twin Falls counties. During the last two years thousands of acres of commercial orchards have been planted in Lincoln and Twin Falls counties, due to the fine showing made by the old orchards as well as the young orchards planted at the opening of the large irrigated tract in this district, and I would estimate we have over 20,000 acres planted to orchards. The largest are $1240,1,000$ and 400, with 80 and 40 by the score.

There are 19 bonded nurserymen in the district, 16 of whom are raising nursery stock, and several more who will take out bonds soon.

As the appropriation for this district is insufficient for the work, I have taken care of the most important part of the work, as far as the funds would allow, and with the change in the horticultural law made by the last legislature, pertaining to the inspection of all nursery stock within the state before shipment at the nursery, and the holding of all interstate shipments by the railroads for inspection before delivery, additional work was given to the inspectors, and this has all been taken care of. While this part of the work has taken about two months time from the regular orchard inspection, it has been the means of saving the growers of the district thousands of dollars by protecting them from unreliable nurserymen, and at the same time give the nurseryman who is growing: and selling clean trees a chance to do business.

The number of days employed for the year 1911 was $2341 / 2$; and for the year 1912178 days, or an average of $181 / 2$ days per month.

The acreage inspected during the two years is about as follows- 


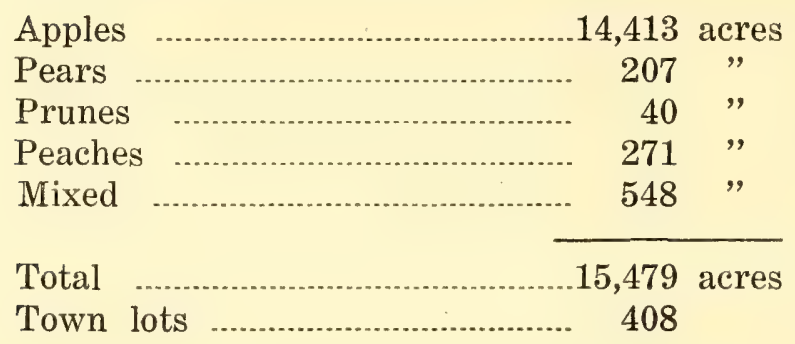

Number of miles traveled by team and railroad:

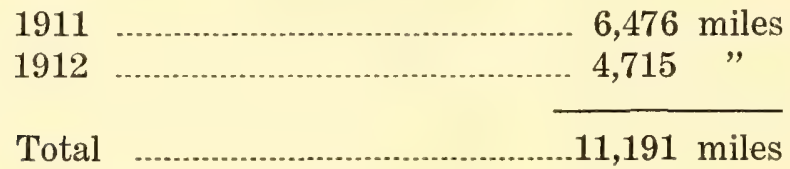

There are hundreds of small orchards all over the district that have not been inspected, as well as a great many commercial orchards planted during the last two years.

The general condition of the orchards is good. In Hagerman there are about five orchards that have some San Jose scale. For the past three years the orchards have been well sprayed and those not sprayed were cut down and burned.

The principal pests with which we have to contend are codling moth, woolly aphis, green aphis, pear blight, Red Spider and San Jose scale. The scale has been found only in Hagerman valley, and the growers have it well under control.

In spraying for codling moth the growers in general have been very successful, several power sprayers have been bought and the old hand pumps thrown on the junk pile, where, I trust, they will rest in peace.

The pear blight showed up here this summer but did very little damage outside of a few non-commercial varieties that are subject to blight. I had to revisit practically all of the orchards on the tract, as a great many of the growers were not familiar with blight.

In closing, will say that in carrying on the work in the 
last two years I have had the assistance and support of nearly all the fruit growers and the community generally. As the state appropriation for this district is insufficient for the work, on petition of the tax payers and fruit growers to the county commissioners of Twin Falls and Lincoln counties, appropriations by both these counties were made sufficient to permit me to carry on my work which was necessary as a great many are growing their first orchards and the assistance I have been able to give them in pruning and general care has been greatly appreciated.

(Signed)

Yours respectfully,

C. W. BRANNAN,

Deputy Inspector, Dist. No. 9.

DISTRICT No. 10.

Oakley, Idaho.

Mr. J. U. McPherson,

State Horticultural Inspector, Boise, Idaho.

Dear Sir-You will find herein a detailed report of official acts as deputy horticultural inspector for District No. 10, for the year 1912. The number of days actually employed was 36, and miles traveled, 506. The number of orchards visited was 344 , containing 524 acres.

In this district we have pear blight, codling moth, woolly and green aphis. One orchard is infested with San Jose scale, but it is isolated and the pest is well under control. Blight is bad in the canyons along the streams where willows and other brush grows. Oakley, Marion and Island are free from blight. There was an extra good crop of fruit in these three places, and it was the cleanest that it has been for years. All trees were sprayed properly last spring, and this, with the cool nights, gave us particularly clean fruit. The plan of serving notices in writing and following them up to see that the work is properly done is a good thing.

Rupert, Burley, Heyburn and that section of the country has been a good market for all fruits raised in 
this district. No fruit was shipped out of the state. We have really no commercial orchards which are bearing. The majority of the trees are apples, but all kinds do well here.

Our county fair was a success. This is a great help to fruit growing as there are many questions asked and much good is done.

More money must be allowed for this work by the state. One hundred dollars for this district is insufficient. Had it not been that the people of this district petitioned the county board for one hundred dollars, and the board seeing the necessity of allowing the same, this district would have fared on small rations.

Many trees are ordered for next spring's planting. Some are putting out as much as forty acres. All stock shipped in the last year was good.

Peddlers handled most of the fruit of this district, and I know of none that was handred but what was clean. The same was true of the stores. (Signed)

JOHN ADAMS, Deputy Inspector, Dist. No. 10.

DisTRICT No. 11.

\section{Malad, Idaho.}

Mr. JOHN U. McPherson,

State Horticultural Inspector, Boise, Idaho.

Dear Sir-I beg to report on the work I have done as deputy horticultural inspector for District No. 11 for the year 1912.

My district is in much better shape than it has ever been before. The people who own orchards are seeing the benefits of inspection and are doing everything possible to help the good work along. They have done much more cleaning up and trimming of their orchards than they have before, and they are beginning to see the benefits to be derived from taking care of their trees.

In the course of my inspections I have traveled in the neighborhood of about 1,500 miles, though there are 



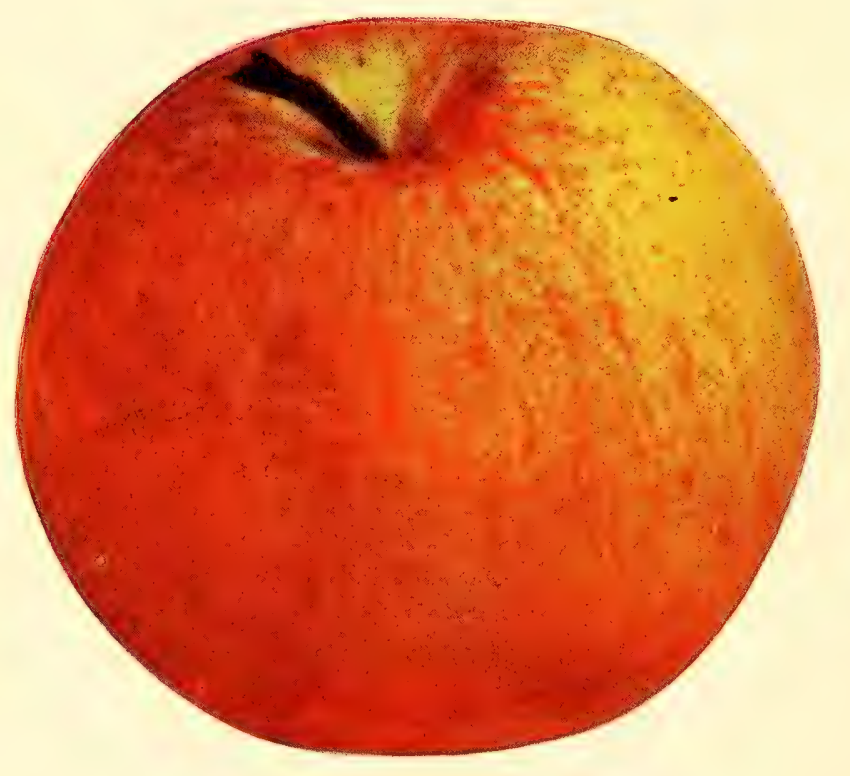

ROME BEAU'TY 
oniy 1,800 acres in this district, it being scattered from one end to the other, but from the returns that are coming from the orchards it is sure to increase the number of acres greatly in the next few years. This district is too large for one man to cover it as it should be, and if an appropriation large enough could be obtained for this district I would recommend that the district be cut in two and the results of the work would be a great deal better. The time is so short to do the work that it is an impossibility for one man to look after it as it should be.

(Signed)

Very respectfully,

T. J. Evans,

Deputy Inspector, Dist. No. 11.

\section{DISTRICT No 12.}

Paris, Idaho.

MR. J. U. McPhERson,

State Horticultural Inspector,

Boise, Idaho.

Dear Sir-In compliance with your letter asking for a general statement as to the condition of my district regarding its increase in orchard, and the general care of the same, the number of miles I have traveled, etc., etc., I have this to say:

The condition of my district is good, there has been great improvement; the increase in orchard is over as much again, about 2,000 acres, and the people are taking better care of their orchards than ever before. The ifruit shipped in is better than usual. By the present outlook I think the number of acres which will be planted next spring will be large. The people have done good spraying, and they see the benefit that it has done. They all say the law is a good one and they can see the good it is doing. The number of miles I have traveled is 966 .

(Signed)

Very respectfully, JoHN NORTON, Deputy Inspector, Dist. No. 12. 


\section{DISTRICT No 13.}

Blackfoot, Idaho.

Mr. JoHN U. McPherson,

State Horticultural Inspector, Boise, Idaho.

Dear Sir-I have the honor to submit to you the following general report of the horticultural inspection work in District No. 13.

As shown by the monthly reports presented during the season from May 1st to the present date, I have inspected 4,101 acres of orchard, and have traveled 4,3411/4 mile: in the pursuit of my official duties.

There are about 8,000 acres of orchard in the district, and in addition to this there have been 5,000 young: trees shipped into the district within the last thirty days for fall and spring planting, besides the trees which are sold by the local nurseries.

The local nurseries and the commercial orchards in the district are in very good condition and indications point to a large increase in orchard acreage next year.

There has been more fruit marketed from this district during the present year than in five years previous. This is not because so much more fruit has been grown, but because facilities for marketing the fruit have improved. Two fruit packing and shipping associations have been established in Blackfoot, and although they have been in business for only a few months, they have both handled a large amount of fruit. There have also been more fruit buyers in the field than ever before which indicates a growing demand for the quality of the fruit produced in this district.

Since the state appropriation for horticultural inspection work was limited in amount, two counties, Bonneville and Fremont, made appropriations from their funds of $\$ 150$ and $\$ 250$ respectively, to further the work in those counties.

One arrest was made in this district for selling infected fruit, in violation of the state horticultural law. The defendant in the case pleaded guilty and was fined.

(Signed)

H. T. BRANGMAN,

Deputy Inspector, Dist. No. 13. 
DistRICT No 14.

Mr. JOHN U. MCPHERSON,

Salmon, Idaho.

State Horticultural Inspector, Boise, Idaho.

Dear Sir-Complying with your request, I send my report as horticultural inspector of District No. 14.

This district comprises Custer and Lemhi counties. The sections where orchards grow are in the Salmon river valley, and the Lemhi river valley. The former is over 150 miles long; and the latter is $50 \mathrm{miles}$, and the altitude of these valleys varies from 3,500 feet to 7,000 feet. The bearing orchards are nearly all in the Salmon river valley.

No fruit has ever been shipped from this district as there has never been enough to supply the home demand.

Since the advent of the railroad in April, 1910, a number of commercial orchards have been planted and many more will be planted next spring:

The fruits of this district are principally apples, pears, cherries and the smaller fruits. Strawberries and raspberries especially grow to perfection.

The Wealthy, Jonathan, Alexander and McIntosh reach perfection in quantity, quality, color and size in apples. Many other kinds are planted which seem to do well, such as Rome Beauty, Northwest Greening, King: David, etc. The Delicious, McIntosh, Rome Beauty, Winter Banana and Jonathan are the principal varieties being planted for commercial purposes.

Pears of all kinds do exceedingly well in all parts of this district. No prettier sight can be seen than the cherry trees when the fruit is ripe. They bear such burdens of rich, juicy cherries. The Dukes and Morrellos, at present, are the leading kinds as they are perfect in every way.

All the young orchards have made strong, vigorous growth during the past two years. Very few pests are found. A few borers and aphis are found, which are common. Only one orchard has had blight and one 
small section was infested by codling moth. Such trees were sprayed with arsenate of lead. Spraying was followed up so closely that the pest is practically exterminated. Thus far Custer and Lemhi counties are practically free from pests.

In 1911 the crops were immune in all kinds of fruit. In 1912 the crops did not quite equal those of 1911. A failure of the fruit crops has never been known in this district.

During 1911 and 1912 I have traveled 1,217 miles, and inspected and reinspected 952 acres, and inspected and reinspected 53 town lots.

Respectfully submitted,

(Signed)

H. C. ChaFFEe, Deputy Inspector, Dist. No. 14. 
APPENDIX 



\title{
DESCRIPTIONS OF COLORED PLATES.
}

\author{
(Descriptions of Apples taken from "The Apples \\ of New York.")
}

\section{M c I N T O S H R D}

This variety belongs to the Fameuse group. It is adapted to a wider range of localities than the Fameuse. The fruit is very attractive in appearance, of bright deep red color and good size. The flesh is very tender, perfumed and delicious. It is desirable for local markets and special trade but because of its lack of firmness it is less suitable for general handling. As grown at this station it begins to ripen in late September or early October. In western New York it cannot be expected to keep much later than Detober in ordinary storage without considerable loss but in cold storage it may be held until December or January (31). When grown in more northern or elevated regions it is often held in good condition till midwinter or later. It is susceptible to scab but this may readily be controlled with proper treatment. The crop ripens unevenly and a considerable portion of the fruit is liable to drop before it is ready to pick. On this account it is best to make two or three pickings. In some localities the tree is said to be a somewhat slow grower and not satisfactorilv productive, but more often it is found to be a rather strong grower, hardy and healthy. It comes into bearing rather young and is a reliable cropper, yielding good crops biennially and sometimes annually. It has not been sufficiently tested to demonstrate fully its value for commercial purposes but it is regarded as one of the most promising varieties of its class for general cultivation in New York.

Historical. - Originated as a chance seedling on the McIntosh homestead, Matilda township, Dundas county, Ontario, where Allan McIntosh began the propagation of this variety in the nursery about 1870 (20) It has been widely disseminated. It is now commonly propagated by nurserymen, and its cultivation is on the increase in New York.

Tree.- Vigorous, with numerous small, slender laterals. Form roundish or spreading. Twigs above medium to short, straight or nearly so, rather slender; internodes long to below medium. Bark bright reddish-brown, lightly streaked with scarf-skin; slightly pubescent. Lenticels quite numerous, small, oval or elongated, raised. Buds deeply set in bark, medium to below, plump, obtuse to acute, free, slightly pubescent.

Fruit-Above medium, sometimes large, pretty uniform in shape and size. Form roundish to somewhat oblate, regular or faintly ribbed, obscurely angular. Stem short, stout or moderately slender, 
usually not exserted, often with irregular protuberances. Cavity large, acuminate or somewhat acute, wide, medium in depth, somewhat broadly furrowed, often partly russeted. Calyx small, closed or partly open; lobes short to long, narrow, acute. Basin pubescent, rather small, medium in depth, narrow, abrupt, smooth or obscurely furrowed.

Skin thin, moderately tender, smooth, readily separating from the flesh, clear whitish-yellow or greenish washed and deeply blushed with bright red and striped with carmine; highly colored specimens become dark, almost purplish red with the carmine stripes obscure or obliterated, overspread with thin lilac bloom. Often the effect of the deep red is heightened by lively contrast with one or more spots of the clear pale yellow ground color where some twig or leaf pressed closely against the growing fruit. Dots whitish or yellow, usually very small.

Calyx tube short, conical or funnel-shape with broad limb. Stamens median to basal.

Core medium size, usually abaxile; cells usually wide open; core lines nearly meeting. Carpels roundish to elliptical, narrowing toward base and apex, smooth, much concave. Seeds medium brown, rather large, acute.

Flesh white or slightly tinged with yellow, sometimes veined with red, firm, fine, crisp, tender, very juicy, characteristically and agreeably aromatic, perfumed, sprightly, subacid, becoming mild and nearly sweet when very ripe, very good to best for dessert.

Season October to December or later.

\section{B A R T E T T P E A R}

Origin, England. Large, obtuse pyriform; surface uneven; skin thin, bright clear yellow, with blush on the sunny side of exposed specimens, sometimes a little russet. Flesh white, buttery, juicy, highly perfumed, vinous flavor. Ripens in midsummer. It is one of the few choice varieties that succeed over a wide range of country and is more largely grown for commercial purposes than any other variety. Excellent for canning, preserving and cvaporating.

\section{WHITE PEAR M A N}

This is an old favorite dessert apple in portions of the middle west from Ohio to Kansas. It appears to succeed better in those regions than it does in New York. It is not recommended for planting in that state.

Historical.- Warder says: "This favorite fruit was brought to Indiana by some of the early pomologists, in the days of saddlebag transportation. In a lot of grafts, two varieties, having lost their labels, were propagated and fruited without name. Being considered Pearmain shaped, they were called respectively Red and White Winter Pearmains. The former proved to be the Esopus Spitzenberg; the latter has never yet been identified, though believed to be an old eastern variety." For a time it was confused 
with an old New Jersey apple by the name of Michael Henry Pippin, and Elliott fell into the error of publishing White Pearmain and White Winter Pearmain as synonyms of Michael Henry Pippin but it was finally conceded that White Pearmain and Michael Henry Pippin are distinct varieties $(4,7)$. In 1858 it was catalogued by the American Pomological Society as White Winter Pearmain (5). Since 1897 (13) it has been listed as White Pearmain but it is very doubtful whether this change will be generally accepted by fruit growers and fruit dealers. This variety has been little grown in New York and is now seldom or never planted there.

Tree.- Vigorous, form spreading. Twigs short, stout, blunt at tips, generally straight; internodes vary from short to long. Bark reddish-brown overlaid with heavy scarf-skin, white pubescent. Lenticels conspicuous, numerous, above medium, elongated, raised. Buds large, projecting, acute, quite pubescent, free.

Fruit.-Below medium to nearly large, uniform in size and shape. Form roundish ovate or roundish approaching oblong conic, varying to roundish conic, somewhat ribbed, pretty symmetrical Stem medium to long. Cavity rather small to above medium, acute, deep, moderately narrow to broad, somewhat furrowed, sometimes russeted. Calyx medium to large, usually closed; lobes long, acute. Basin small to medium, oblique, shallow and obtuse to medium in depth and rather abrupt, medium in width, often distinctly furrowed, wrinkled, pubescent.

Skin tough, smooth, slightly waxen, pale yellow, or at first greenish, with a shade of brownish-red. Dots numerous, pale or russet, often submerged, usually larger and much elongated about the cavity.

Calyx tube long, conical.

Core medium to rather large; cells closed or partly open; core lines somewhat clasping. Carpels rather flat, broad or roundishcordate, emarginate, mucronate, tufted. Seeds light brown, medium to large, rather wide, plump, obtuse to acute, tufted.

Flesh slightly tinged with yellow, firm, fine-grained, crisp, tender, juicy, mild subacid, sprightly, very pleasantly aromatic, very good to best.

Season December to March.

\section{W I N E S A P}

Winesap is one of the oldest and most popular apples in America. It is known in all the apple growing sections from Virginia westward to the Pacific coast. An indication of its popularity may be gained from the fact that according to Bailey's Inventory (27) there were, in 1892 , seventy-three nursery firms offering Winesap for sale as compared with sixty-four firms offering Baldwin, fifty-eight offering Northern Spy and forty-eight offering Rhode Island Greening. It should be borne in mind, however, that the number of firms selling a variety is not an altogether true criterion of the number of trees sold.

Like various other old varieties, Winesap has many seedlings which partake more or less of the characters of the parent. The best known of these are Arkansas, Arkansas Black, Paragon and Stayman Winesap.

The tree is a rather vigorous though not particularly rank grower, comes into bearing early and is a remarkably regular 
cropper. It does best on rather light, rich, deep soils and does not succeed on heavy clays or in low, damp locations. In unfavorable situations the trees are apt to be short-lived and in New York are less hardy than the leading commercial varieties of that region. Although Winesap is a well-known market apple, yet with the exception of the Piedmont region in Virginia and certain districts elsewhere it has not proved generally successful for the commercial orchard. In New York it seldom reaches good medium size. In more southern latitudes and under favorable conditions the fruit is well colored and of good quality, but excepting on young trees or on soils of more than average fertility it averages too small for a good market variety. When well grown it is of very good quality and attractive in appearance, being quite uniform in shape and size and of good dark red color. As grown at this station it is in season from January to June with April as the ordinary commercial limit (47). When grown farther south its season extends to February in ordinary storage and to April in cold storage. It is a good shipner and stands heat well before going into storage, but late in the season it often scalds, particularly when not well colored.

Historical. - Nothing definite is known of the origin of Winesap. Coxe speaks of it as being "the most favored cider fruit in the West Jersey." From this fact many writers have referred to West Jersey as the region of its origin or probable origin but such statements seem hardly warranted by the evidence.

Tree.-Medium in size, vigorous. Form roundish-spreading, rather straggling and open. Twigs rather stout, rather short to above medium; internodes short. Bark very dark reddish-brown with thin gray scarf-skin, somewhat pubescent. Lenticels especially clustered just below the nodes, conspicuous, round or elongated, variable in size but usually above medium. Buds large to medium, broad, usually rather obtuse but sometimes acute, free or nearly so. Foliage thin; leaves usually not large, narrow.

Fruit.-As grown in New York averages even smaller than that which is grown farther south. It is pretty uniform in size and shape. Form usually conical, sometimes roundish, nearly truncate at base, nearly regular or obscurely ribbed, symmetrical. Stem medium to short, rather slender. Cavity medium to rather small, acute to acuminate, narrow to rather broad, deep, symmetrical or somewhat furrowed, often more or less lipped, often russeted or with outspreading russet rays. Calyx medium to large, closed; lobes long, narrow, acuminate. Basin rather small to medium, often oblique, shallow to rather deep and abrupt, narrow to moderately wide, distinctly furrowed, somewhat wrinkled.

Skin medium in thickness, tough, smooth, glossy, bright deep red indistinctly striped and blotched with very dark purplish-red over a distinctly yellow ground color or green if not fully mature, overspread with faint bloom. Dots rather small, scattering, whitish, sometimes in conspicuous contrast with the deep red skin, especially toward the cavity. Prevailing effect bright deep red.

Calyx tube quite variable, conical or funnel-shape. Stamens marginal.

Core medium to small, abaxile with a hollow cylinder in the axis, narrowing toward the apex; cells pretty uniformly developed, symmetrical, open or nearly closed; core lines clasping. Carpels broadly roundish, much concave, but slightly emarginate if at all, mucronate. Seeds below medium to above, wide, plump, obtuse.

Flesh tinged with yellow, veins sometimes red, very firm, rather conrse. moderately criso, very juicy, sprightly subacid, good to very good. 


\section{YELLOW NEW TOW N}

Tree-More vigorous and more erect than that of the Green Newtown, the branches growing more freely, the laterals showing less tendency to droop and the twigs averaging somewhat longer than is the case with the Green Newtown, otherwise, we find that the two varieties, as Downing says (10) "grow alike."

Fruit-The technical description of the fruit of the Green Newtown applies well to the Yellow Newtown in all points excepting the color of the fruit and the color and flavor of the flesh. At fruit harvest the Yellow Newtown is distinguishable from the Green Newtown because both the yellow and the pink tones are more highly developed. When they are fully mature and more highly colored apples are bright yellow, often with distinct pinkish blush, especially about the base. Less highly colored fruit is greenish-yellow shaded more or less with duller brownish-pink through which narrow streaks of the ground color often appear, combining with the streaks of whitish scarf-skin to give a somewhat striped effect. In general appearance it is decidedly more attractive than the Green Newtown, and its flesh is apt to be more distinctly tinged with yellow, milder, less sprightly and more highly aromatic.

\section{T A L I N P R U N E. \\ (Prunus domestica).}

The Italian Prune is one of the most widely grown of all piums. Its home is Italy and it is grown in all of the plum regions of continental Europe; is well known in England; is third or fourth in popularity in the Atlantic States of America; is by long odds the leading plum in the Pacific Northwest where it is chiefly used in prune-making and is grown somewhat for prunes and for shipping green in California. There are several reasons why this plum is so popular. To begin with, it is finely flavored, whether eaten out of hand, stewed or otherwise prepared for the table or cured as a prune. The fruit is a little too tart to be ranked as a firstclass dessert plum and yet it is one of the best of the prunes for this purpose, though it must be fully ripe to be fit for dessert; in cooking it changes to a dark wine color, very attractive in appearance, with a most pleasant, sprightly flavor; as a cured prune the flesh is fine and meaty, yet elastic, of good color and a perfect freestone, making when cooked the same attractive looking, fineflavored, sprightly sauce to be had from the green fruits; the prunes from this mriety, too, are noted for long-keeping. In the uncured state the variety keeps and ships well. The trees are usually large, hardy, productive, well formed and bear regularly; yet they are not ideal and the variety fails chiefly in tree-characters. The trees are often capricious to soil and climate, do not always bear well, seem to be susceptible to diseases, are preyed upon by insects and suffer in particular from dry or hot weather. Were all of these troubles to befall the variety at one time it would of necessity give way to better sorts, but happily they are to be found for the most part in illy adapted conditions or in certain seasons; the Italian prune well cared for in locations to which it is suited must long remain one of the leading plums despite the faults of the trees. 
The Italian Prune originated in Italy at least a century ago and has long been common in northern Italy, especially in the vicinity of Milan. The London Horticultural Society catalog for 1831 first mentions it in England and the following year it was described in America by Prince as an excellent prune recently introduced from Europe. The American Pomological Society recommended it in 1856 as worthy of further testing, and in 1862 it was added to the fruit catalog list of this society. The origin of the name Fellenberg, a very common synonym, is explained by Lauche, who says: "It came to Germany through Mr. Fellenberg and is therefore spread under his name and also under the names Schweizerwetsche and Fellenberger Zwetsche." He further adds that the variety "is still not known in Germany as it deserves, considering its quality, size and productiveness."

Tree of medium size, rather vigorous, spreading or upright, low topped, hardy, usually productive; branches ash-gray, smooth, with small, raised lenticels; branchlets short, with internodes of medium length, greenish-red changing to brownish-drab, pubescent, with small lenticels; leaf-buds of medium size and length, conical, appressed; leaf-scars large.

Leaves folded upright, obovate or oval, two inches wide, four and one-half inches long; upper surface green, pubescent; lower surface silvery green, heavily pubescent, apex and base acute, margin doubly crenate, with small, dark glands; petiole five-eighths inch long, above medium thickness, pubescent, tinged red, with from one to three globose, greenish-brown glands usually on the stalk.

Season of bloom intermediate and short; flowers appearing after the leaves, one and three-sixteenths inches across, in the buds tinged yellow, changing to white when expanded; borne on lateral spurs, rarely on lateral buds, singly or in pairs; pedicles threequarters inch long, thick, pubescent, greenish; calyx tube green, campanulate, pubescent at the base; calyx lobes long and narrow, acute or narrowly obtuse, pubescent on both surfaces and along the glandular-serrate margin, reflexed, inclined to curl at the tips; petals oval or obovate, dentate. tapering to broad claws of medium length; anthers yellowish; filaments seven-sixteenths inch long; pistil pubescent at the base. equal to the stamens in length.

Fruit late, season short; one and seven-eighths inches by one and one-half inches in size, long-oval, enlarged on the suture side, slightly compressed, halves unequal; cavity very shallow and narrow, abrupt; suture shallow to medium; apex bluntly pointed; color purplish-black, overspread with very thick bloom; dots numerous, small, light brown, somewhat conspicuous; stem inserted at one side of the base, one inch in length, pubescent, adhering well to the fruit; skin thin, somewhat tough, separating readily; flesh greenish-yellow changing to yellow, juicy, firm, subacid, slightly aromatic; very good to best; stone free, smaller than the cavity, one inch by five-eighths inch in size. irregular oval, flattened, roughened and pitted, necked at the base, abruptly tipped at the apex; ventral suture prominent, heavily ridged, sometimes strongly winged; dorsal siture widely and deeply grooved.

\section{E L I C I O U S}

Large, distinctive in shane; color, brilliant dark red blending into golden yellow at the blossom end. The calyx is one of its 
ever-characteristic features, having five protuberances which are more or less pointed or Hat rounded, depending on section where grown. Quality very good; flavor sweet, slightly touched with acid, very aromatic. Flesh is fine grained, very crisp, exceedingly juicy. One of the strongest, hardiest and vost vigorous; aphis-resistant and a late bloomer; blossoms strongly frost-resistant. Originated at Peru, Madison county, Iowa, by Jesse Hiatt.

\section{O M I E P E A R}

Origin, France. Fruit large, varying from roundish to obtuse pyraform. Greenish yellow, clear yellow at maturity, some russet shaded with crimson on sunny side; stalk short and stout, inclined and set in a shallow cavity; calyx small, open, in a deep uneven basin. Flesh white, fine grained, sweet, rich, slightly aromatic flavor. October and November.

\section{W E A L T H Y}

This variety is particularly valuable for cold climates because the tree is very hardy and the fruit sells well, being bright red and good in quality for either dessert or culinary uses. It is in season from October to early winter or mid-winter. In ordinary storage its commercial limit is October, but in cold storage it may be kept till January or later. It does not stand heat very well before going into storage and goes down rather quickly (41). Young trees or trees which are making a thrifty growth produce fruit of good size, but mature, slow-growing trees are apt to yield a considerable percentage of undersized fruit, especially when they are overloaded, as is often the case. The crop ripens unevenly, and more than one picking should be made in order to secure the fruit in prime condition. If it is left upon the tree until fully colored there is apt to be considerable loss by dropping. The tree is a good thrifty grower when young, but with maturity it becomes a moderate or rather slow grower, forming a medium sized or rather dwarfish tree. Wealthy is being planted for commercial purposes in many parts of the state, but in most localities the trees are as yet comparatively young; in some sections of the state it is being planted more than any other apple of its season. Trees that have become old enough to develop the tendency to produce rather small fruit are in some places being grafted over to other sorts. In other places, fruit growers, by adopting such treatment as thinning the fruit and keeping the soil fertile, continue to produce apples of good marketable size when the trees are mature.

Historical.- Originated by Peter M. Gideon, Excelsior, Minn., from seed of the Cherry Crab, which he obtained about 1860 from Albert Emerson, Bangor, Me., $(11,28)$. Ragan (42) states that the fruit was first described in the Western Farmer in 1869. It has been extensively disseminated, particularly in those apple-growing districts where a tree of superior hardiness is especially desired. It is generally listed by nurserymen and its cultivation is gradually increasing. 
Tree.- Somewhat dwarfish to medium size, moderately vigorous with short, moderately stout, curved branches. Form upright spreading or roundish, open and somewhat drooping. Twigs long, curved, slender; internodes long. Bark dark brown, lightly streaked with scarî-skin; pubescent. Lenticels quite numerous, medium to small, oblong, not raised, rather conspicuous. Buds medium size, broad, plump, obtuse, free, pubescent.

Fruit.-Above medium to large when well grown but often small on old trees; pretty uniform in shape and quality but more or less uneven in size. Form roundish conic, slightly flattened at base, regular, symmetrical. Stem usually short to medium, but rather long on small fruit and rather slender. Cavity decidedly acuminate, rather deep, moderately narrow to rather broad, russeted. Calyx medium size, closed or partly open; lobes broad, obtuse to acute. Basin medium in depth to rather shallow, rather narrow, abrupt, smooth, symmetrical.

Skin thin, tough, pale yellow or greenish, blushed and marked with narrow stripes and splashes of red, deepening in highly colored specimens to brilliant red, very attractive. Dots numerous, small, inconspicuous, pale or russet. Prevailing effect bright red.

Calyx tube conical approaching funnel-form. Stamens median.

Core medium to very small, abaxile or sometimes slightly abaxile; cells symmetrical, slightly open; core lines clasping. Carpels medium to rather small, roundish, narrowing toward base and apex, smooth, flat. Seeds moderately dark brown, above medium, rather acute.

Flesh whitish, sometimes stained with red, moderately fine, crisp, tender, very juicy, agreeable subacid, sprightly, somewhat aromatic, good to very good.

Season October to January.

\section{G R I M E S}

Fruit beautiful rich golden-yellow, attractive in form and excellent either for dessert or culinary use. It can hardly be called a standard market variety but in some markets it sells well. It is not a good keeper and is apt to scald in storage. It is in season about with Hubbardston. The tree is a biennial or sometimes an annual bearer and a good cropper. Favorable reports on it have been received from certain localities in New York but generally as grown in that state does not develop in size, color or quality as well as it does in more southern latitudes, and there is a high percentage of loss from drops and culls. Some few New York fruit growers consider it a fairly profitable variety but generally it is regarded less favorably and it has failed to become a standard apple either in the home orchards or in the commercial orchards of the state. The indications are that it will never be grown in New York to any considerable extent.

Historical.-Originated in West Virginia. Fruit from the original tree was sold to the New Orleans traders as long ago as 1804 (6). It has become generally disseminated throughout the Ben Davis regions of the south, west and southwest, where it is often planted for home use and is highly esteemed as a dessert apple, but it is not grown extensively in many localities in the commercial orchards. It has long been known in scattering locali- 
ties in New York and old trees of it are found in some orchards, but it has not been generally planted.

Tree-Moderately vigorous; branches short, stout, curved, crooked. Form upright spreading or roundish, inclined to droop, rather dense. Twigs short to long, straight, moderately stout; internodes short. Bark dull brownish, rather lightly mottled with scarf-skin; pubescent in spots and at tips. Lenticels scattering, small to large, roundish or oblong, not raised, rather inconspicuous. Buds medium, broad, obtuse to acute, free, varying from slightly pubescent to quite pubescent.

Fruit-Medium to large. Form roundish oblong, often flattened at the ends, sometimes inclined to conic, pretty regular, sometimes obscurely ribbed, sometimes oblique, symmetrical, uniform; sides often unequal. Stem short to medium. Cavity broad, deep, acute to acuminate, often russeted. Calyx rather large, closed, lobes long, reflexed, often separated at base. Basin abrupt, deep or moderately deep, rather wide, somewhat furrowed.

Skin tough, somewhat rough, clear deep yellow with scattering pale yellow or russet dots.

Calyx tube yellow, very broad at the top, conical, deep. Stamens basal.

Core medium to rather small, somewhat abaxile; cells usually pretty symmetrical, closed, or somewhat open; core lines meeting or somewhat clasping. Carpels roundish, emarginate, coneave. Seeds numerous, medium or below, somewhat tufted, plump, acute to obtuse.

Flesh yellow, very firm, tender, crisp, moderately coarse, moderately juicy, subacid, rich, aromatic, sprightly, very good to best.

Season November to January or February. Commercial limit, December or January.

\section{J O N A T H A N}

This is a fruit of the Esopus Spitzenberg class. It is very beautiful, of a brilliant red color, highly flavored and of excellent quality for either dessert or culinary use. It excels its parent in hardiness, productiveness, health and vigor and is adapted to a wider range of territory, but the fruit is not so large nor does it keep as well as that of Esopus Spitzenberg. In New York state it does fairly well in favorable localities if grown on rich soil and given careful attention bit even under such circumstances it does not usually attain as good size as it does in certain portions of the valleys of the Ohio, Mississippi and Missouri and in the irrigated districts in the mountain regions farther west. As grown in New York it is ordinarily rather small with a comparatively high percentage of uneven and irregular fruit, and it is not at all adapted to the general trade. At its best it is one of the most desirable varieties for the fancy trade at the holiday season. Its season is about the same as that of Tomplins King. It may be kept through the winter but when held in ordinary storage later than January dark spots are liable to develop in the skin and seriously injure the appearance of the fruit. Handled in this way its commercial limit is December or early January. In cold storage its commercial limit varies from January to March or sometimes later. $(30)$.

As grown in New York the tree is but a moderate grower and 
for this reason it is well to top-work it upon some stock that is more vigorous, such as Northern Spy, Baldwin or Rhode Island Greening. It does not grow much above medium size and may be planted more closely than Baldwin. Particular attention should be given to keeping the soil fertile, well supplied with humus and well tilled, and the trees should be thoroughly protected from injurious insects and fungus diseases. Under favorable conditions the tree is a reliable cropper, bearing good crops biennially or in some cases almost annually. It comes into bearing rather young. Usually the fruit hangs pretty well to the tree. It is not recommended for general commercial planting in New York but in some places under good management it has proved a profitable variety.

Historical. - The first published account which we find of the Jonathan is that given by Judge J. Buel, of Albany, in 1826, in an article on "Observations on the Utility of a Descriptive Catalogue of Garden and Orchard Fruit," addressed to the members of the New York Horticultural Society, in which he presents "A Descriptive Catalogue of some of the most valuable apples propagated in the nurseries of this state." In this catalogue the Jonathan is listed as the Esopus Spitzenberg (New) with the synonym Ulster Seedling. (1). In 1829 Judge Buel sent specimens of the fruit to the Massachusetts Horticultural Society with the statement that it was "An Esopus seedling and sometimes called the New Spitzenberg." It originated on the farm of Mr. Philip Rick, of Woodstock, Ulster county, New York (7). According to Downing the original tree was still alive in 1845. It was at first disseminated under various names, all of which were soon superseded by the name Jonathan which was assigned to it by Judge Buel in honor of Jonathan Hasbrouck by whom his attention was first called to the variety. It has been widely disseminated throughout the applegrowing regions of New. York but in none of them is it grown extensively. It is extensively planted in regions farther west and south, where, as above stated, it is recognized in many localities as one of the leading commercial varieties.

Tree.-Medium in size, a moderately vigorous or rather slow grower. Form roundish or spreading, somewhat drooping, rather dense. Twigs medium in length, nearly straight, rather slender; internodes short. Bark dark brownish-red mingled with dark green, and heavily coated with scarf-skin; pubescent. Lenticels usually very scattering, sometimes moderately numerous, small to medium or sometimes large, roundish to oblong, not raised. Buds medium, plump, rather narrow, acute to obtuse, free, pubescent. Leaves medium or below, rather narrow.

Fruit.-Medium to rather small, rarely large. Form roundish conic to roundish ovate, often somewhat truncate, regular; pretty uniform in shape and size. Stem medium to long, rather slender. Cavity acute to acuminate, deep to very deep, wide, symmetrical, sometimes slightly furrowed. Calyx small, closed. Basin deep to very deep, very abrupt, wide to moderately narrow.

Skin thin, tough, smooth, pale bright yellow overlaid with lively red, striped with carmine. When well colored the fruit is almost completely covered with red which deepens to purplish on the sunny side and often shows a beautiful contrasting bit of clear pale yellow about the cavity where a twig or leaf lay in contact with the skin. Less highly colored fruit has more of a striped appearance particularly toward the basin. Dots minute, usually inconspicuous. Prevailing effect attractive lively deep red.

Calyx tube rather small, funnel-shape or sometimes conical. Stamens basal to median.

Core medium or below, axile or nearly so; colls symmetrical but 



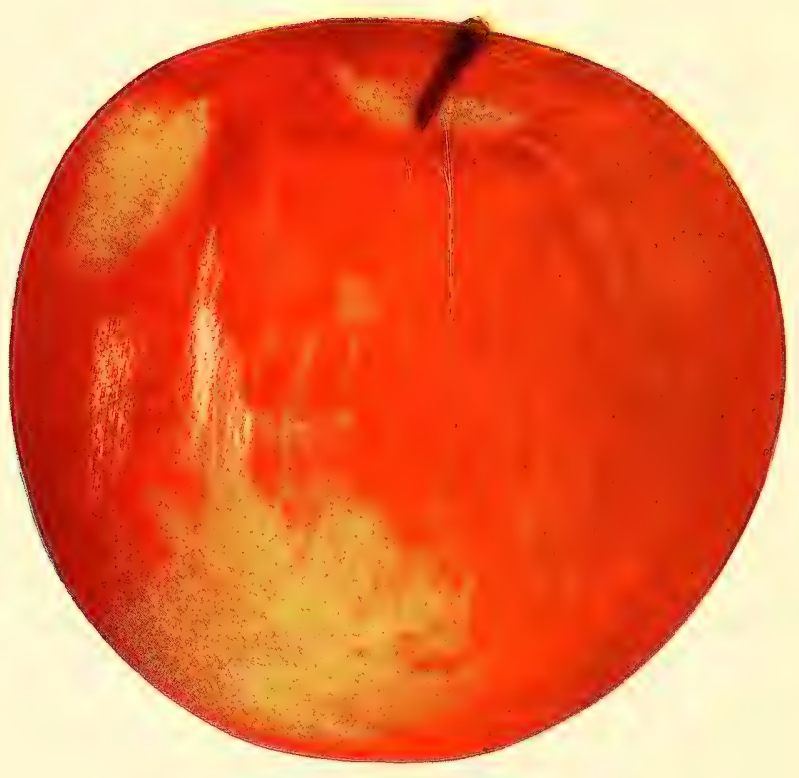

GANO 
often not uniformly developed, usually closed, sometimes open; core lines clasp the funnel cyllinder. Carpels rather concave, roundish to roundish cordate, emarginate, smooth. Seeds rather large, long, acute to acuminate, dark, numerous.

Flesh whitish or somewhat yellow, sometimes with tinge of red, firm, moderately fine, crisp, tender, juicy, very aromatic, sprightly subacid, very good to best.

Season November to January or later.

\section{ELBERTA PEACH}

Large to very large, yellow, with beautiful blush; firm, a little coarse, but tender and good. While quality is not the highest, it has made more money for the orchardist than any other peach. Tree a rank, vigorous grower, healthy and fairly hardy, one of the most dependable.

\section{W A G E N E R}

Wagener, at its best, is an apple of superior excellence. The color is a beautiful bright red with some contrasting pale yellow; it has fine texture, high flavor and excellent quality. It is very desirable for culinary uses but is especially esteemed for dessert. It is in season about with Tompkins King or from October to February, yet often some portion of the fruit may be kept in ordinary storage till late in spring. Its commercial limit is December, or, in cold storage, about February 1. It does not stand heat well before going into storage and is quite apt to scald toward the close of the season, particularly if not well colored. After scalding it goes down quickly $(29,30)$. Often there is some loss from drops, especially if the crop is not picked as soon as it is well colored, and many times there is a rather high percentage of loss of fruit that is unmarketable because it is undersized or misshapen. In the nursery Wagener is a pretty good grower, upright and well formed; in the orchard it is quite vigorous at first, but as it advances in maturity it usually becomes a rather weak grower, with branches full of fruit spurs. It comes into bearing at an early age and so long as it remains healthy it is a reliable cropper, yielding moderate to rather heavy crops biennially or nearly annually. In many cases it overbears so that the fruit does not all develop properly in size and color. Under such circumstances it is a great advantage to thin the fruit. To get best results the thinning should be done as early as June. Under favorable conditions the crop is pretty uniform in size, color and quality.

The tree is often short-lived, but some report that it is longer lived when top-worked upon hardier and more vigorous stock, such as Northern Spy, Baldwin and Tolman Sweet. On account of its dwarfish form and habit of coming into bearing at an early age it is recommended by some fruit growers as a filler to plant between the rows of longer-lived apple trees. Some fruit growers consider it a profitable variety, but many do not. Although it was 
introduced about a half century ago and it is now sufficiently well known so that it may perhaps be regarded as a standard market variety, yet it has not established itself to any considerable extent in the commercial orchards of this state and is not being extensively planted.

Historical.- The first published reference to the Wagener which we find is that given in the Report of the New York State Agricultural Society for 1847, in which it is stated that it was awarded second premium as a seedling of merit (1). In 1848 it was again presented for competition and was placed by the committee in the list of first class apples, awarded an additional premium and also a diploma. An illustrated description of it was published in the report of this society for that year with the remark "This very fine apple the committee considers a desirable addition to the list of first-rate fruits. Its appearance is prepossessing, as is also its size and form." (2). An account of the history of Wagener was also given in which it was stated that in the spring of $1791 \mathrm{Mr}$. George Wheeler brought with him from Dover, Duchess county, N. Y., to Penn Yan, Yates county, a quantity of apple seeds which he sowed that spring in the nursery upon his farm which he was then reclaiming from the wilderness. In 1796 Abraham Wagener, from whom the name of the apple is derived, bought this seedling nursery and planted trees from it upon his place in what is now the village of Penn Yan. In 1848 it was remarked that the old tree was producing an annual and abundant yield of beautiful and delicious fruit. It continued to bear full crops until about the year 1865 (15). After it was brought to the notice of the State Agricultural society, the Wagener soon began to be propagated quite extensively and it has since become widely disseminated throughout the country. In 1892 Wagener was being offered quite generally by nurserymen throughout the country except in the north Mississippi valley, the Rocky Mountain region and the plains from Nebraska to Texas (22). It is generally known throughout New York, but is not planted extensively in any section of the state.

Tree.-Dwarfish to medium size, at first moderately vigorous but soon becoming a slow grower; branches short, stout and filled with spurs. Form roundish to spreading, open. Twigs short to medium, often somewhat curved, moderately stout, usually quite blunt; internodes medium to short. Bark clear dark reddish brown mingled with olive green, lightly streaked with scarf-skin; pubescent near tips. Lenticels scattering, medium or below, elongated or sometimes roundish, not raised. Buds medium to rather large, sometimes projecting, plump, acute, free, pubescent.

Fruit. - Medium to rather large. Form oblate to roundish oblate, broadly ribbed or irregularly elliptical; sides often unequal. Stem short to moderately long, maderately thick to rather slender. Cavity variable, acute, moderately deep to deep, broad or sometimes compressed and rather narrow, often angular or furrowed, sometimes thinly russeted. Calyx small to medium, closed or partly open; lobes small, usually short, acute to acuminate, connivent, reflexed. Basin medium in width and depth, abrupt, somewhat furrowed.

Skin thin, tough, smooth, glossy, bright pinkish-red striped with bright carmine and mottled and streaked with thin whitish scarf-skin over a clear, pale yellow background. Dots numerous, whitish or russet, sometimes mingled with light russet flecks. Prevailing color, bright light red.

Calyx tube long, rather narrow, funnel form, often elongated and extending to the core. Stamens median to marginal.

Core below medium to moderately large, somewhat abaxile with 
hollow cylinder in the axis, carrying to nearly axile; cells symmetrical, closed or open; core lines clasping the funnel cylinder. Carpels broadly roundish or approaching elliptical, but little emarginate if at all, smooth or nearly so, mucronate. Seeds moderately numerous, rather small to above medium, short to moderately long, moderately wide, obtuse, rather light brown; often some are abortive.

Flesh whitish slightly tinged with yellow, moderately firm, rather fine-grained, crisp, tender, juicy to very juicy, subacid, aromatic, sprightly, very good to best.

Season October to November, to February or later.

\section{A N JOU PEAR}

Origin, France. Large, obtuse pyriform; stem short, thick, fleshy. Skin greenish-yellow, sometimes shaded with dull crimson and sprinkled thickly with brown dots; calyx very small, open, stiff, in a small basin surrounded with russet. Flesh whitish, melting, juicy, brisk, vinous; late autumn to eariy winter. Tree vigorous, open round head; fruit evenly distributed and of uniform size. An excellent market variety.

\section{R O M E}

When well grown this fruit is of good size, uniform, fair, smooth and handsomely colored. It is thick skinned, stands handling remarkably well and is a good keeper. It is held in cold storage till May or later. It goes down gradually in storage and if properly colored is not subject to scald (39). It has an established reputation in market and sells at good prices. As compared with Baldwin it is not quite so good in quality either for dessert or for culinary uses but the tree comes into bearing at a much earlier age and under right conditions is more nearly an annual cropper. It is not as well adapted as Baldwin for general cultivation in New York state, the fruit often being less reliable and less satisfactory in size and color, the foliage less healthy and the tree less vigorous and not so large. Although it is an old variety it has not been sufficiently tested in New York to determine the range of its proper cultivation. Generally speaking, it succeeds better farther south, as, for example, in some districts in New Jersey and along the Ohio river. It appears to be better adapted to bottom lands and to fertile sandy or gravelly loams than to heavy clay soils. Evidently it develops proper size, color and quality more often when grown in southeastern New York than it does in cooler and more elevated regions in the interior of the state, yet in some localities in western New York on warm, fertile, well-drained soils it attains good size and good color and gives promise of being satisfactory in commercial orchards. The tree is apt to overbear and in unfavorable locations as it advances in maturity there is often a considerable loss in undersized or noorly colored fruit. Although it is a good grower there appears to be some advantage in topgrafting it upon some more vigorous stock. When top-worked on bearing trees it usually produces some fruit within two or three 
years from the time of grafting or budding. The fruit is supported by a long stem and usually hangs to the tree remarkably well eren in high winds. It is somewhat subject to the attacks of the acab and requires thorough and careful preventive treatment in order to protect it from injurious insects and diseases.

Historical.-Originated by $\mathrm{H}$. N. Gillett in Lawrence county, Uhio. Brought to the notice of the Ohio Convention of Fruit Growers in 1848 as a new variety $(1,14)$. It is holding its own as a profitable commercial variety in that section of the country (31) and also in certain other southern apple-growing districts $(30,34$, 38 ), but Stinson reports that in Missouri it is an uncertain bearer, and not a safe variety to recommend for general planting although some Missouri fruit growers recommend it for planting in some locations (34). Although occasionally old trees of this variety are found in New York, Rome is as yet but little known among New York fruit growers. Within recent years it has been planted or grafted in commercial orchards to a limited extent and for the most part in an experimental way.

Tree.- Tree not a very strong grower in the nursery but in the orchard it is rather vigorous and attains good medium size. Form at first upright but later it is roundish to somewhat spreading and drooping, with rather slender lateral branches. Twig: moderately stout, sometimes slender, moderately long; internodes short. Bark mottled in brownish-red and green, rather bright. Lenticels medium to large, scattering, conspicuous, round to oblong, raised. Buds deeply set in bark, very short, broad, obtuse, appressed. Leaves rather long; foliage not particularly robust.

Fruit.- Fruit medium to very large, usually averaging abovo medium, pretty uniform in size and shape. Form roundish to roundish-conic or slightly oblong, regular or faintly ribbed, usually symmetrical but sometimes with sides unequal. Stem characteristically long, slender, and often oblique. Cavity medium to rather large, characteristically obtuse and smooth, moderately shallow to rather deep, wide, sometimes compressed or lipped, often gently furrowed, green or red, never russeted. Calyx rather small to meaium, closed or somewhat open; lobes usually converging above but slightly separated toward the base. Basin small to medium, shallow to a moderately deep, narrow to medium in width, sometimes abrupt, usually a little furrowed or wrinkled.

Skin thick, tough, smooth, yellow or greenish, more or less mottled with bright red which in highly colored specimens deepens to almost solid red on the exposed cheek, striped with bright carmine. Dots rather numerous, whitish or brown, small. Prevailing effect, red, or red mingled with yellow .

Calyx tube cone-shape or approaching short truncate funnel form, often with fleshy pistil point projecting into the base. Stamens marginal to median.

Core medium to large, abaxile; cells sometimes unsymmetrical, open; core lines meeting or slightly elasping. Carpels roundish to ovate, narrowing both toward base and apex, sometimes obtusely emarginate, mucronate. Seeds numerous, medium in size, plump, acute to somewhat obtuse, slightly tufted, light and dark brown.

Flesh nearly white, with slight tinge of yellow or green, firm, moderately fine-grained to a little coarse, rather erisp, juiey, slightly aromatic, agreeable mild subacid, commonly good but not high in quality.

Season November to April or May. 


\section{G A N O}

This is a variety of the Ben Davis type. In the nursery the tree resembles Ben Davis very closely. As grown in western New York the fruit is more highly colored, but on the average is somewhat smaller than that of Ben Davis. It is less striped in appearance and more of a solid, deep red color, often with a contrasting spot of clear yellow where it has been closely covered by a leaf or twig. In this respect and in its deep, abrupt basin it suggests Jonathan, as at times it also does by its brilliant, deep red or purvlish color. It is very attractive in appearance, stands handling well and is a good keeper. In quality it is perhaps a little superior to Ben Davis. The tree comes into bearing young, and is an excellent cropper, bearing regularly and abundantly. It has not been tested very many years in New York, but it appears to be adapted to about the same region as Ben Davis.

Historical. Origin obscure. Brought to notice in Missouri about twenty-five years ago and disseminated under the name Gano $(1,5,6)$. It is supposed by some that the original stock came from Kentucky. (5). Some believe that Gano is the same as Black Ben Davis. It certainly resembles Black Ben Davis very closely but the preponderance of evidence at present seems to favor the opinion that it is of distinct origin (16).

Tree-Tree moderately vigorous; branches long, moderately stout and inclined to droop; laterals willowy, short, slender. Form like that of Ben Davis, upright, spreading, becoming somewhat drooping, rather dense. Twigs short to rather long, somewhat curved, markedly geniculate, moderately stout; internodes short to rather long. Bark bright brownish-red mingled with olive-green, lightly overcast with mottled and streaked gray scarf-skin; pubescent. Lenticels not conspicuous, scattering, medium, round to ovate or often elongated, slightly raised. Buds small to medium with prominent shoulder, plump, obtuse, appressed, decidedly pubescent, deeply set in bark.

Fruit-Fruit medium to sometimes large. Form roundish conie, usually regular, symmetrical: uniform in size and shape. Stem medium to long and slender. Cavity acute, deep, rather broad, symmetrical, sometimes slightly furrowed or compressed, usually with radiating green russet or red russet. Calyx medium or above, closed or partly open; pubescent; lobes rather broad, acute to zeuminate. Basin abrupt, moderately narrow to rather wide, often deep.

Skin smooth, waxy, clear light yellow, mottled and blushed with bright light pinkish-red often deepening to a purplish-red, more or less obscurely striped. Dots numerous, small, inconspicuous. Prevailing color fine red.

Calyx tube short, cone-shape with fleshy pistil point projecting into its base, or sometimes elongated funnel-form. Stamens median to marginal. Core below medium to large, somewhat abaxile with a comparatively rather wide hollow cylinder at the axis; cells elosed, or partly open, usually symmetrical but often not uniformly developed; core lines meeting when the calyx tube is cone-shape but elasping the funnel-cylinder when it is funnel-form. Carpels broadly roundish or elongated, slightly tufted, emarginate. Seeds numerous, broad, obtuse, large, dark, sometimes tufted.

Flesh whitish slightly tinged with yellow, firm, moderately tender, rather coarse, moderately crisp, juicy, mild subacid, good or nearly good in quality.

Season about the same as that of Ben Davis, extending from December to May in western New York. Commercial limit in common storage Mareh, in eold storage April. 


\section{NORTHWESTERN GREENING}

Attractive in color for a green or yellowish apple but apt to be variable in size and not uniform in shape. It is hardier than Rhode Island Greening and on that account some consider it worthy of cultivation in districts where the climate is too severe for the Rhode Island Greening. The fruit has a serious fault in that the flesh within the core lines is apt to be corky and discolored. It cooks evenly and quickly and when cooked has a fine yellow color but is not of high flavor or quality, being much inferior in this respect to Rhode Island Greening. As a desert apple it ranks fair to good in quality. At this station it has not been a satisfactory keeper in common storage, the rate of loss being high in November and sometimes in December, moderate through the winter and gradually rising to high or very high in the closing weeks of its season. A large part of the fruit does not reach prime condition before January, a considerable portion of it remains sound until the close of the winter and some of it may keep till June. The tree is hardy, vigorous, a fine erect grower in the nursery, and a good, strong grower in the orchard. It does not come into bearing very early but eventually becomes productive and is a reliable biennial cropper.

Historical.- Originated in Waupaca county, Wisconsin. Introduced in 1872 by E. W. Daniels. It has been pretty widely disseminated throughout the northern portions of the apple belt where very hardy trees are desired. It has as yet been planted very little in New York.

Tree.- Vigorous, with moderately long, stout, crooked branches. Form upright, becoming quite roundish or spreading, inclined to droop, dense. Twigs moderately long, curved, stout, with large terminal buds; internodes medium to long. Bark clear reddishbrown, lightly mottled with scarf-skin, lightly pubescent. Lenticels quite numerous, medium to large, oval or elongated, raised, very conspicuous, pale and contrasting clearly with the bright smooth bark. Buds large, broad, plump, obtuse, free, projecting, slightly pubescent.

Fruit.-Medium to large or very large, variable in size and form. Form commonly roundish but varying to oblong or to oblate and often inclined to conic, more or less irregular, sometimes elliptical, sometimes ribbed. Stem medium to short. Cavity rather small to large, acute to acuminate, moderately narrow to wide, deep, often compressed or lipped, often with outspreading russet. Calyx variable, small to large, closed or open. Basin small to large, narrow to wide, usually abrupt, moderately deep, furrowed and wrinkled.

Skin smooth, somewhat waxy, clear pale yellow or greenish, sometimes faintly blushed. Dots varying from small to large and irregular, usually whitish and submerged, sometimes gray with russet point. Prevailing effect clear yellow or greenish.

Calyx tube moderately wide, conical or approaching urn-shape. Stamens median.

Core medium or above, usually abaxile or nearly so, cells usually symmetrical, closed or sometimes open; core lines meeting or somewhat clasping. Carpels broadly roundish, truncate at base, narrowing toward the apex, mucronate, but slightly marginate, if at all. Seeds very small, variable in shape; often some are abortive.

Flesh tinged with yellow, medium in texture, crispness and firmness, juicy, with slight aroma, mild subacid, fair to good. 


\section{Idaho Spraying Calendar}




\begin{tabular}{|c|c|c|}
\hline Inseet or Dimense. & Plant Attacked & What to Spray With \\
\hline 1 Codling Moth .... & Apple, pear & $\begin{array}{c}\text { Arsenate of lead or } \\
\text { white arsenate }\end{array}$ \\
\hline 2 San Jose Scale ........... & $\begin{array}{c}\text { Nearly all deciduous } \\
\text { trees }\end{array}$ & Sulphur-lime wash \\
\hline $\begin{array}{c}3 \text { Oyster Shell Bark } \\
\text { Louse }\end{array}$ & Apples, mainly. ................... & Sulphur-lime wash ........ \\
\hline $\begin{array}{l}4 \text { Peach Worm or Twig } \\
\text { Borer }\end{array}$ & $\begin{array}{l}\text { Peach, gometimes plum, } \\
\text { apple and cherry. }\end{array}$ & Sulphur-lime wash \\
\hline 5 Green Aphis ................... & Apple, plum, prune. & Sulphur-lime wash ........ \\
\hline 6 Black Aphis ................. & Cherry and peach & $\begin{array}{l}\text { Whale oil and quassia } \\
\text { chips or black leaf } \\
\text { tobacco dip 1 part } \\
\text { to } 70 \text { parts water }\end{array}$ \\
\hline 7 Wooly Aphis ................. & Apple & \\
\hline 8 Aphis .... & Hop, rose, house plant & Whale oil and quassia.. \\
\hline 9 Cabbage Worm & Cabbage, caulfflower ...... & Paris green dust ............. \\
\hline 10 Cabbage Aphis ....... & Turnip and Cabbage & Whale oil and quassia.. \\
\hline$\overline{11}$ Slug .... & Pear .... & $\begin{array}{l}\text { Arsenate of lead or } \\
\text { white arsenate }\end{array}$ \\
\hline 12 Slug ... & Cherry ....... & $\begin{array}{l}\text { Arsenate of lead or } \\
\text { white arsenate } \ldots . . . . . . .\end{array}$ \\
\hline 13 Red Splder ............. & Fruit trees and bushes & Sulphur-lime Wash .... \\
\hline 14 Blister Mite ........... & Pear leaf .... & Sulphur-lime wash ........ \\
\hline 15 Peach Tree Borer .... & Peach and prune ............... & \\
\hline 16 Flathead Borer ........ & Apple, mainly ...... & \\
\hline 17 Cottony Scale .... & $\begin{array}{l}\text { Maple, currant and pop- } \\
\text { lar ....................... }\end{array}$ & Kerosene emulsion ... \\
\hline 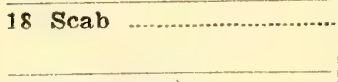 & 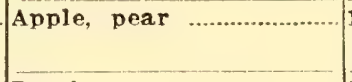 & 1. part lime and sul- \\
\hline 19 Leaf Curl .... & Peach & $\begin{array}{l}\text { Sulphur-lime wash. } \\
\text { Add salt }\end{array}$ \\
\hline 20 Peach Mildew & Peach & $\begin{array}{l}\text { Weak solution sulphur- } \\
\text { lime wash }\end{array}$ \\
\hline 21 Gooseberry Mildew & Gooseberry & $\begin{array}{l}\text { Weak solution sulphur- } \\
\text { lime wash }\end{array}$ \\
\hline
\end{tabular}




\section{First Spraying} While the blossoms are fall- Repeat when first brood of eggs are
ing. Spray with force di-hatching. Spray third time three weeks Spray third time three weeks rectly into every flower. after the first worms appear under Use a Bordeaux nozzle. the bands and again three weeks later

In the spring before the buds Be sure and cover every portion of burst

When the leaves are off the trees the tre
contact.

After the eggs under the scales hatch (May 15 to June 15) spraying with kerosene emulsion 1 part to 10 parts water or whale oil soap 1 ib to 5 gallons water is effective.

Just as the buds swell in the spring

When the leaves are off the trees

When the insects appear and bofore they curl the leaves

When the insects appear whale ofl soap and quassia chips or tobacco sheep dip are the most effective remedies.

Remove the soll about two feet around the trunk and dissolve a pound of lye in a bucket of water or use prepared solution of lime and sulphur in proportion of 1 part $L-S$ to 5 parts water and pour on the exposed roots, covering immediately with dirt.

When the insects appear .......

Bepore the worms eat into the cabbage .............................

Just as soon as the insects appear

When the insects appear ......

Spray early in the season when the fruit is nicely formed

When the leaves are of the trees ............................................

When the leaves are of the trees ........................................

\begin{tabular}{|c|c|}
\hline & $\begin{array}{l}\text { Dig out the worms in fall and spring } \\
\text { with a knife. During growing season } \\
\text { whitewash base of trunk. }\end{array}$ \\
\hline & $\begin{array}{l}\text { Dig out the worms in fall and spring } \\
\text { with a knife. During growing season } \\
\text { whitewash base of trunk. }\end{array}$ \\
\hline $\begin{array}{l}\text { When insects become cottony } \\
\text { (May) }\end{array}$ & $\begin{array}{l}\text { Add more soap than the formula } \\
\text { calls for. Repeat } 10 \text { to } 12 \text { days later } \\
\text { if necessary. }\end{array}$ \\
\hline Tuat before the blossoms open. & $\begin{array}{l}\text { Again while the last blossoms are } \\
\text { falling. Spray once or twice during } \\
\text { the season, later if thought necessary. }\end{array}$ \\
\hline Just before the buds open & $\begin{array}{l}\text { Be sure and add the salt to the lime } \\
\text { and sulphur mixture. }\end{array}$ \\
\hline ust Before the buds burst. & \\
\hline
\end{tabular}

Make dust of one part Paris green and 25 parts bran or flour.

Repeat if necessary.

If you wait until insects appear the ruit is ready to pick which makes it undesirable to spray at this time.

This will kill the winter eggs. If the mite appears in summer, use the kerosene emulsion.

Dig out the worms in fall and spring whitewash base of trunk.

Repeat when the fruit is well set. 











\section{LIBRARY OF CONGRESS \\ ||||||||||||||||||||||||||||||||||||||||||||||||

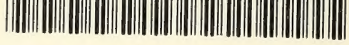

000091, 7428A 